Faith C. M. Kitch

\title{
The Literary Style of Epifanij Premudryj "Pletenije sloves"
}

Verlag Otto Sagner München - Berlin - Washington D.C.

Digitalisiert im Rahmen der Kooperation mit dem DFG-Projekt „Digi20“

der Bayerischen Staatsbibliothek, München. OCR-Bearbeitung und Erstellung des eBooks durch den Verlag Otto Sagner:

http://verlag.kubon-sagner.de

() bei Verlag Otto Sagner. Eine Verwertung oder Weitergabe der Texte und Abbildungen, insbesondere durch Vervielfältigung, ist ohne vorherige schriftliche Genehmigung des Verlages unzulässig. 


\section{SlaVistische BEITRÄGE}

BEGRÜNDET VON ALOIS SCHMAUS

HERAUSGEGEBEN VON JOHANNES HOLTHUSEN UND JOSEF SCHRENK

REDAKTION: PETER REHDER

Band 96 
FAITH C. M. KITCH

\section{THE LITERARY STYLE OF EPIFANIJ PREMUDRYJ PLETENIJE SLOVES}

VERLAG OTTO SAGNER · MÜNCHEN 1976 


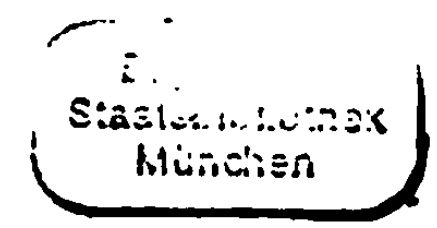

ISBN 3-87690-108-1

Copyright by Verlae otto Sagner, Minchel. $197 \epsilon$ Abteilunk der Firma zubon und Sagner, Müncken Lruck: Alexender Gro'mann

3 München 19, Ysenturgstire.Be $7^{I}$ 


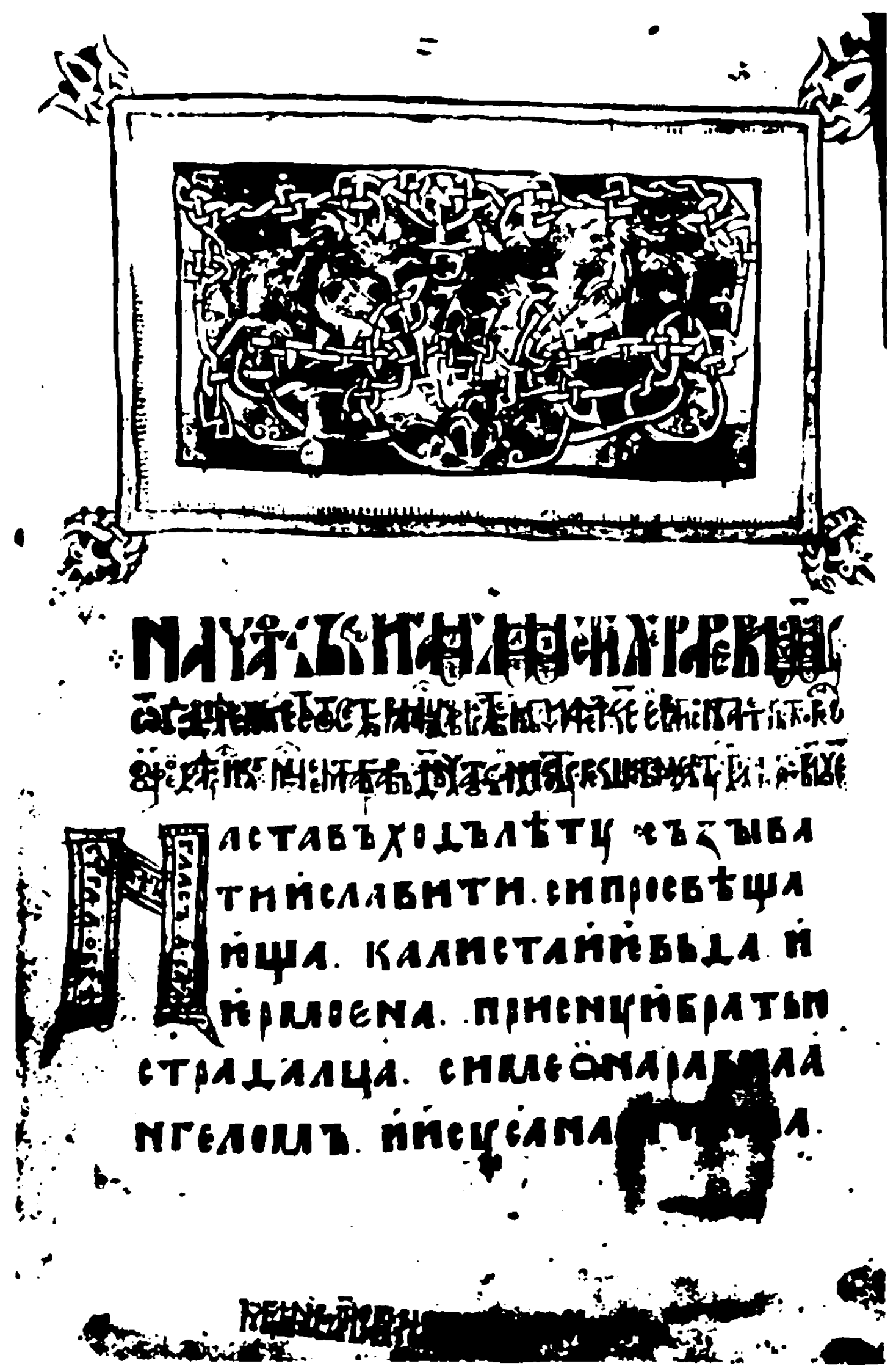

Verso of the first folio of a Stixirar' of 1380 (GBL MS Troic. (fond 304) no. $22, \mathrm{f} .1 \mathrm{v}$.$) . From the authorship note at the foot of the folio, it$ may be deduced that the copyist was Epifanij Premudryj. The note reads: многогрђшнын раб божин Епифан в недостаньи свовмь написа сн. 


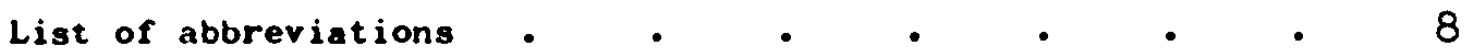

Note on transliteration and reproduction of Cyrillic script. 9

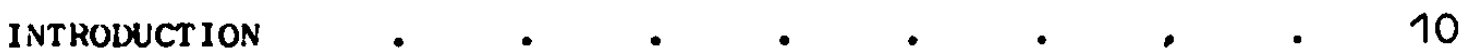

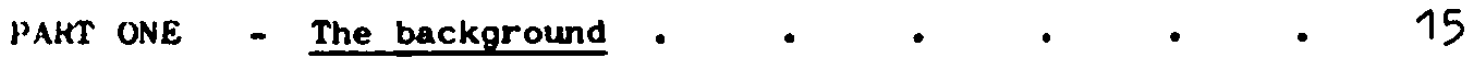

i. Hagiography, its evolution and development 16

ii. Epifanif Premudryj, his wilieu and

influences on him . . . . . 22

PAKT TWO - Structure and composition: studies in distinctive

aspects of the Life of Stefan of Perm' - - 47

Chapter 1. Structure and narrative technique . 48

Chapter 2. Dialogue, monologue and questions. 67

Chapter 3. The mumility topos . . 79

Chapter 4. Antithesis . . . 98

Chapter 5. Epifanij's nethod of composition and

his attitude to the Scriptures . 111

Chapter 6. The role and function of biblical

quotations $\quad . \quad \ldots \quad 131$

Chapter 7. Symbol and historical parallel - 143 


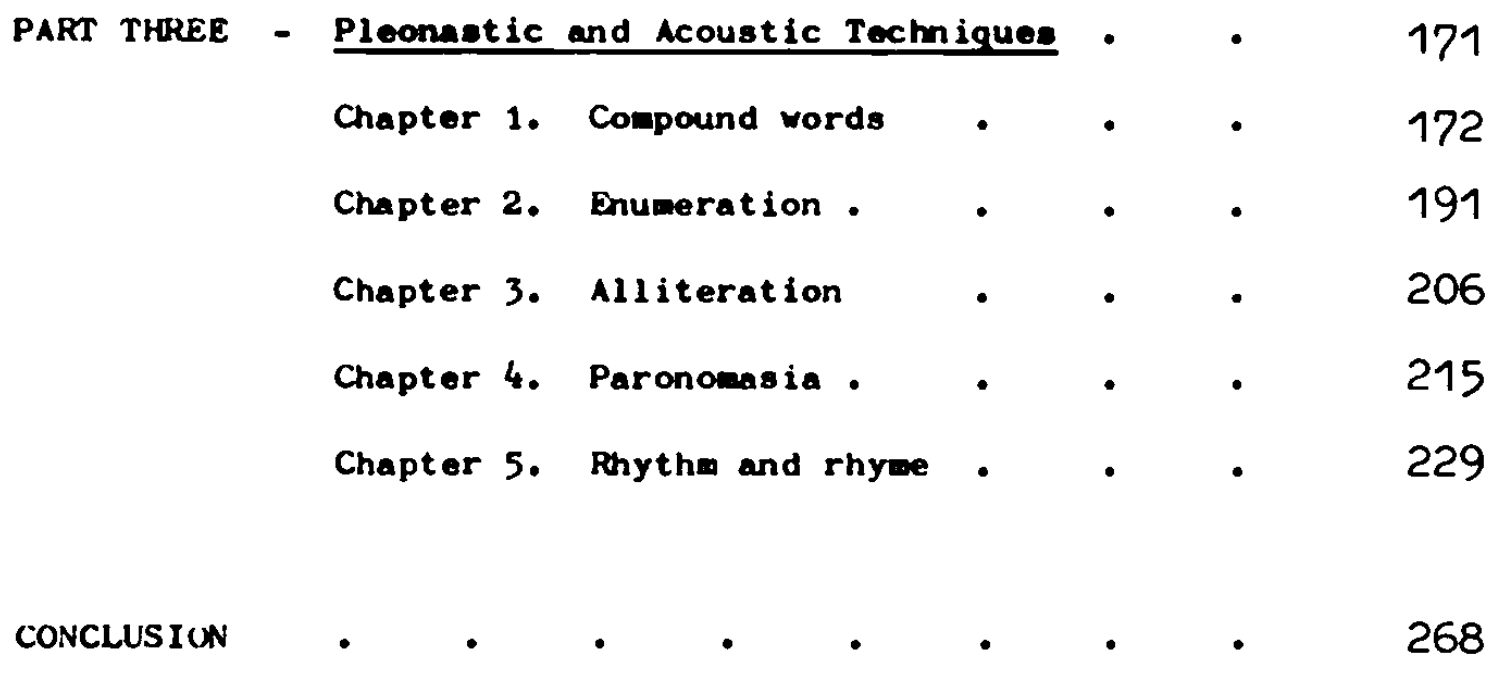

SBLECT IVE BIBLIOGRAPHX

Primary sources • • • • • • • $\quad 275$

Secondary sources • $\quad$ - $\quad$ - $\quad$ - 283 


\section{LIST OF ABBREVIATIONS}

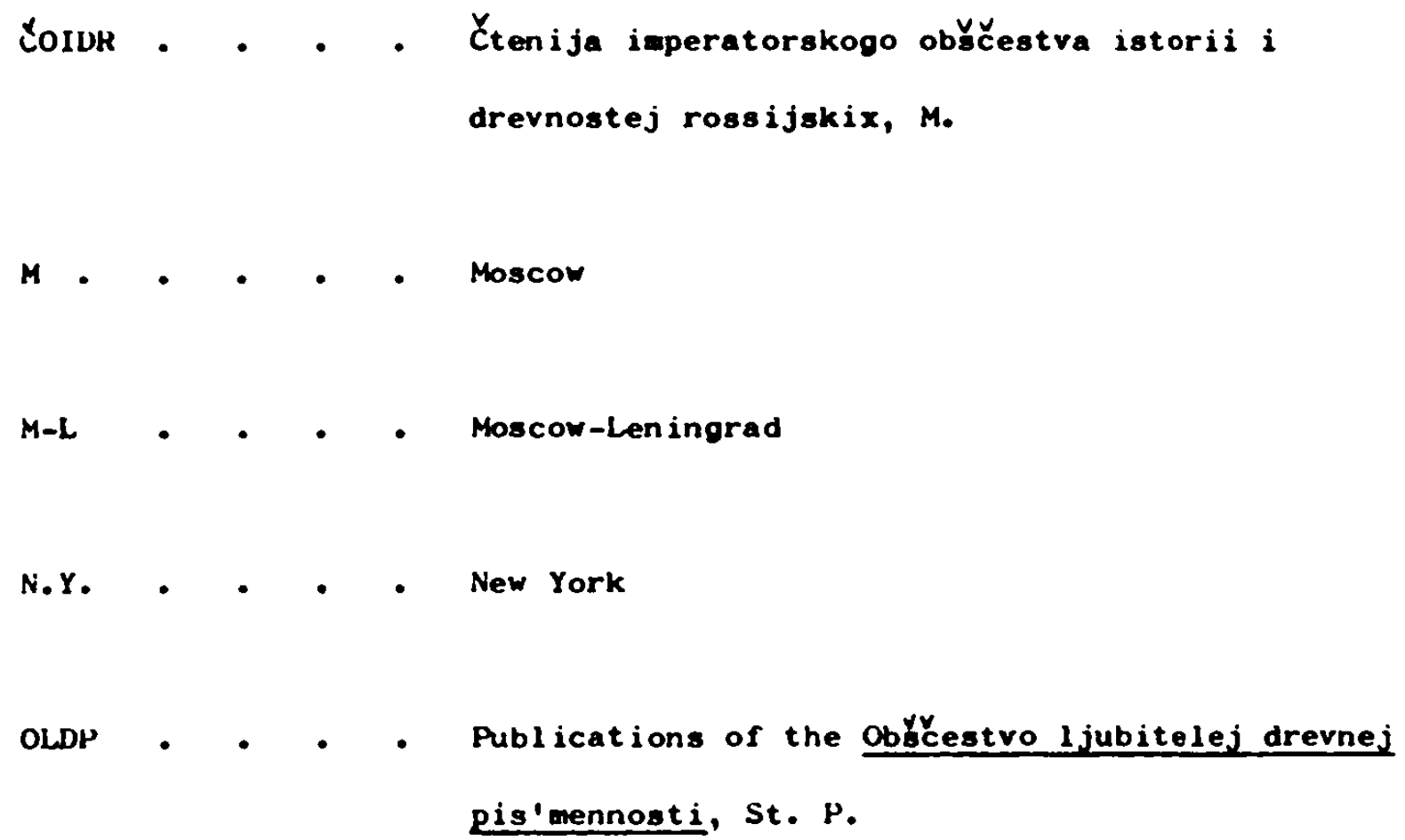


NOTE ON TRANSLITGRATIUN AND REPROLUCTION OF CYRILLIC SCRIPT

\section{Transliteration}

In general the system employed is the ISO, as given by

J. S. G. Simmons (thessian bibliography, libraries and archives;

Oxford, 1973, p. 59,) with the following variants:

Cyrillic

$\boldsymbol{x}$

e

s

$\mathbf{3}$

\section{Transliteration}

$\mathbf{x}$

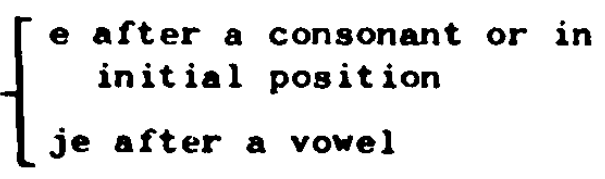
8 $\left\{\begin{array}{l}\text { a for Church Slavonic and } \\ \text { modern Bulgarian } \\ \text { " (medially) for modern }\end{array}\right.$ Russ i an

11. Reproduction of Cyrillic script in quotations

Texts in Russian Church Slavonic have been modernized in accordance with the system employed in Trudy otdela drevnerusskoj literatury, as given by R. F. Lnitrieva ('Frojekt seri monograficeskix issledovanij-izdanij pamjatnikov drevnerusskoj literatury', TOLL, XI, M-L, 1955, p. 495), though i kratkoje is not employed.

Texts in Bulgarian and Serbian Church Slavonic have been given in a form that reproduces as closely as possible the features of the printed editions. Some simplification was essential; thus

8 and oy are both rendered oy

$\omega$ and o are both rendered 0

Abbreviations have been expanded, and superscript letters brought onto the line. Modern punctuation has been adopted throughout. 


\section{N T R O D U C T I O N}

A work of literature is like a tapestry, whose overall effect depends upon terture, colour and design. These are produced by selection and skilful interweaving of threads of many colours. In the same way, the impact of a literary work is produced by its meaning, its tone and feeling, all of which are the result of choice and treatment of the basic material, words. The language of a literary work may be studied not merely for information about the author's use of language but also as a key to the whole effect of the work. For meaning and the medium of expression cannot be separated; the effect of ideas or feelings depends heavily upon the way they are presented to the reader. Likewise the attitude of the writer to his work or to his reader is part of his intention, and 'the verbal means by which these attitudes are established are open to observation'. 1 such conceptions form the springboard for many modern style studies, which attempt to elucidate the essential characteristics of a given writer by identifying the distinctive features of his style. 2 They also underlie this analysis of the literary art of one of lissia's foremost hạiographers, Epifanij Premudryj (d.1419).

Style study requires a close attention to detail, and this follows directly upon a determination to derive general conclusions from observable

1. G. llough, Style and stylistics, London, 1969, p. 10.

2. Hough, op. cit., pp. 59-102, briefly surveys the main trends in Cont inental Duropean work on stylistics and Anglo-American critical writing with similar objectives. The book also contains a useful if short bibliography. H. Hatzfeld, A critical bibliography of the new stylistics, applied to Romance languages, Chapel Hill, N.C., 1953 is exhaustive in its field. For an analysis of the Russian Formalist critics, omitted from Hough's book, see V. Erlich, Pussian Formalism, (jlavistic printings and reprintings, IV), The llague, 1955. 
literary data rather than the intuition of the traditional literary critic.

But only evaluation and intuition can ultimately guide the selection of

aspects worthy of scrutiny, and prompt complex conclusions about the

fundamental qualities of a work. Literary stylistics attempts to support

its conclusions with firm evidence. The implied contrast with traditional

literary criticism which tends towards an impressionistic appronch is best

illustrated by glancing at scholarly work on Epifanij's pletenije sloves.

Though for a long time his style received unsympathetic treatment,

recently it has attracted a measure of favourable attention. 3

3. A negative appraisal of Epifanij's style may be found in

v. 0 . Kijučevskij, Litija svjatyx kak istoričeskij istočnik, M., 1871, p. 93; I. Jaxontov, Żitija svjatyx severnorusskix podvi $Z_{n i k}$ por porskogo kraja kak istoričeskij istočnik, Kazan', 1982, p. 8; Ni. N. jperanskij, Istorija drevnej russkoj literatury, M., 1921, II, p. 104 , et al. Interest in Epifanij and his cultural milieu was stimulated by D. S. Lixačev, 'Nekotoryje zadači izučenija vtorogo južnoslavjanskogo vlijanija $v$ Rossii', Issledovanija po slavjanskomu litcraturovedeniju i fol'kloristike, $\lambda_{i}$, 1960, pp. 95-152, ex!randed into idem, Kul'tura thusi vremeni Andreja iubleva i Epifanija Premdrogo, $\lambda_{1}-L, 1962$. Subsequent work on pletenije sloves includes L. $\lambda$. Imitrijev, 'Nerełennyje voprosy proisxotdenija i istorii ekspressivno-emocional' nogo stilja XV v.', robl, ${ }^{\prime X}, M-L ., 1964$, pp. 72-89; O. r. Konovalova "iravnenije kak literaturnyj prijem $v$ "Litii stefana permskogo", napisannom Epifanijem Premudrym', Sbornik statej po metodike prepodavanija inostrannyx jazykov i filologii; (Leningradskij texnologiceskij institut xolodil'noj promyslennosti), 1, L., 1963, pp. 117-38; idem, 'l'oxval'noje slovo $v$ "Liti i stefana permskogo"',

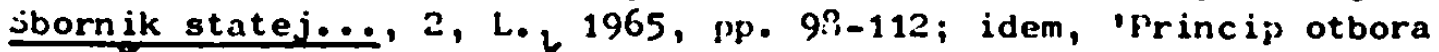
faktiCeskix svedenij $v$ "Litii jtefana permskogo", TUUL, X.IIV, M-L., pp; 136-9; idem, 'Izobrazitel'nyje i emocional'nyje funkcii epiteta $\checkmark$ Litii Stefana Jermskogo', TOUL, A.VVIII, L., 1974, pp. 325-34; A. Nulic, 'srpsko pletenije sloves do 14 stoljeća', ißs, 5, Lagreb, 1963, pp. 117-29; idem, 'Pletenije sloves i hesihazam', 싣, 7 . Lagreb, 1965, pp. 141-56; idem, 'Serbskije agiografy XIII-XIV vv. i osobennosti ix stilja', TCDL, XXIII, L., 1963, pp. 127-42; J.P. Manson, Studies in Pussian hagiography during the period of the second South Slavic influence, Ph.D. thesis for llarvard University, Cambridge, Mass., 1968; V. A. Grixin, 'Principy voplołXenija nravstrennogo ideala $v$ soX inenijax Epifanija Premudrogo', Vestnik moskovskogo universiteta, 4, 1973, pp. 15-25, (an article spoiled by the author's lack of background). 
Lixačev was aware that his observations lacked the backing of detailed research, and called for further work on the whole period." Happily his call wet with a response, but the pieceweal and often unsystematic treatment of pletenije sloves in the work of Konovalova, Doitrijev and Mulit means that firm answers to crucial questions have eluded them. Manson's study is much wore broadly based, and he makes a valuable contribution to knowledge of structure and style in hagiography of the period. His work is marred by its weak and sometiwes contradictory conclusions; Epifanij is either unable to restrain his style, or a great master. 5 Tantalisingly, he is characterised as ewploying materials in a new way, but Mnson never examines the extent of his innovations or the concepts underlying his effusive style. 6 I have here attempted to rectify this situation by a detailed analysis of aspects of Epifanij's pletenije sloves set against a background of the style of the rhetorical vita. In this way a nuwber of important questions may be given firmly-based answers.

Hagiography like other genres of mediaeval literature conformed consistently to a pattern, each writer striving to emulate his predecessors by writing in a manner that would do justice to his subject and show the faithful that he was indeed worthy of their veneration. 7 This could be

4. 'Nekotoryje zadači', p. 152.

5. Manson, op. cit., pp. 118,193 and 228.

6. ibid., p. 228 .

7. The attitudes that lay behind the approach to literature in the Middle Ages are sufficiently familiar not to require elaboration here. A good summary may be found in $I$. Watt, The rise of the novel, London, 1957, pp. 9-36; D. S. LixaČev, Poetike drevnerusskoj literatury, L., 1967, pp. 84-108. On the origins of the concept of a particular style for a particular genres, see E. R. Curtius, Duropean literature and the latin Middle Ages, translated by H. R. Trask, London, 1953, chaps. iv, v. On the system of genres in mediaeval Pussia see Lixacer, Poetika, pp. $24-83$. whereas in Western burope, literature was constantly nourished by two strcams, the Judaeo-Christian and the pagan Roman, whose contrasts led to a literary tradition that was more critical in spirit and tolerant of change, Orthodox bastern burope inherited only ecclesiastical and functional secular forms of literature, and its tradition consequently displays a rigid adherence to those mediaeval attitudes fostered by the Church. 
achieved as much through his method of recounting the life as through the events he had to relate. The external form of a vita cannot therefore be separated from its internal content. Both were profoundly conservative, reflecting the concept of the vita as an ideal portrait. But even though writers deliberately incorporated stereotyped incidents or commonplaces (topoi) together with quotations from the Scriptures or patristic writings into their own compositions, they nonetheless followed an individual approach. Any innovation was contained within literary convention: stylis$t$ ic differences as a consequence are not of kind but of degree. One hagiographer may employ antithesis for example, more intensively than others, or develop traditional topoi to previously unknown lengths. Provided there is a consistent effort in this direction in his vitae, then it is valid to refer to an individual approach to hagiography, convention notwithstanding.

Comparison of aspects of style in any one vita with a postulated hagiographic norm is likely to be most rewarding when the style of the former is obviously distinctive. Close exarination of Epifanij's pletenije sloves yields interesting conclusions about his aims, his method, as well as the extent of his departure from convention. Sore complicated is the problem of whether Epifanij differed significantly from other practitioners of pletenije sloves. Do the same concepts of hagiography inform their vitae? Did Epifanij borrow from his stylistic forerunners? To answer these questions, Epifanij's style as exemplified in the Life of Stefan of 'term', 8 has been compared not only with Greek, Slavonic and Kievan Lives

8. Since one of Epifanij's two vitae, the Life of Sergij of Radonez, has not survived in its original form, attention has been focussed almost entirely on the Life of Stefan of Perm'. The edition employed is Litije sv. Stefana, episkopa permskogo, reprinted from the edition of V. Druzinin of 1897, with an introduction by D. Ciževskij, (ipophoreta Slavica, II), The lague, 1959. For other printed editions of the Life, see the bibliography of primary sources infra. 
but also with the pletenije sloves of the Serb Domantian (d. after 1264) and Patriarch Evtimij of Turnovo (d. 1393). Where it has been deemed necessary, other works, particularly of the late fourteenth and early fifteenth century, have been considered. Painstaking scrutiny of the texture, colour and design that make up Epifanij's traditional tapestry in the Life of Stefan of Perm' is rewarded with significant and interesting conclusions about pletenije sloves. 
P A R T O N E

THY BACISROUND 
i. Hagiography, its evolution and development

The history of hagiographic style, its evolution and literary influences are a necessary background to the analysis of Epifanij

Premudryj's pletenije sloves. The tradition to which he belongs reaches back to the first centuries of Christianity when the oppressed Christian minority in the Roman empire mode brief and simple records of the deaths of martyrs. Only when Christianity became the official state religion in the early fourth century could these Church heroes be celebrated openly. There was a natural desire that their memory should be preserved in suitable literary fashion. The liturgy and ritual became formalised and with it religious literature. The first genre to evolve was the encomium, a panegyric sermon delivered on the feast day of the martyr. Like other genres of later provenance, it relied heavily on existing rhetorical traditions, in this case the pagan funeral encomium. Since the first writers of the eulogy had all received a training in rhetoric as part of a secular education, it was inevitable that they made it a vehicle for the new Christian literature. 1

jubsequently, the accounts of the deaths of martyrs (uassiones) were also rewritten according to the prescriptions of epideictic oratory. At the same time a new type of Church hero emerged; since few were now martyred for their beliefs, attention was turned to saintly men, whether ascetics, ecclesiastics or pious laymen. The value of their example lay not in the manner of their deaths but in the virtue of their lives.

1. For the history of hagiography and the evolution of the various sub-genres, see $H$. Delehaye, Les Passions des martyres et les genres littéraires, Brussels, 1934, pp. 3-7, 183-99; R. Aigrain, L'hagiographie, ses sources, ses méthodes, son histoire, Paris, 1953, pp. 156-63; Manson, op. cit., pp. 1-32; Xr. Loparev, 'Vizantijskije Xitija svjatyx VIII-IX vekov', Vizantijskij vremennik, XVII, st. P., 1911, pp. 1-43. 
However the portrayal of a life presented a new literary problem, resolved by reference both to the classical encomium and to secular biography. 2 The first example is in fact a hybrid form, the vita et passio of Polycarp written by pontius in the third century, ${ }^{3}$ but the biography of saints, vitae, soon developed into an important independent genre.

The evolution of all hagiographie genres owes a good deal to the practice of rhetoric by the Sophists. Rhetoric pervades all genres, secular and religious alike, "though its influence is not overwhelming in hagiography, for not all vitae are written according to its prescriptions. Vitae range from bare accounts, or tales of a fantastic and legendary nature to formal rhetorical Lives. 5 It is the rhetorical type, the most literary and official biography of a saint that is the concern here, for Epifanij was the direct heir of this tradition. The formal vita may be divided according to function; those vitae intended for inclusion in Church services (prolołnyje Zitija or synaxaria) were of necessity very short and did not allow for much rhetorical ornament. Others intended for reading aloud in church or monastery were longer and could possess

a distinct rhetorical structure and complex style. Their length was not limited by the demands of function, but rather by more practical and literary factors such as the amount of material available and the need to keep the reader's attention and elicit the intended reaction in him. Epifanij's vitae belong in this category.

2. For example llermogenes and Apthonius. See Loparev, op. cit., p. 15.

3. Aigrain, op. cit., p. 156.

4. Qurtius, op. cit., pp. 64-72, and 148 discusses how overpowering the presence of rhetoric became in the liest. The same happened in Byzantium. See Cambridge Nedieval llistory, IV, pt. ii, Cambridge, 1967, p. 239.

5. Xr. Loparev, 'Opisanije nekotoryx greXeskix Žitij svjatyx', Vizantijskij vremennik, IV, St. P., 1897, pp. 337-8. 
Whetoric was the tool employed to hamer the material into the proper shape, a shape already determined by the ninth century, ${ }^{6}$ and displaying marked similarities with the structure of the encomium as given by Delehaye. 7 . Wother feature of hagiography typical of mediaeval literature in both East and west was the transformation of topoi into clichés which pervade all parts of the vork. 8 And yet the hagiographer did not feel constrained by these demands, firstly because they tied in with his own psychological attitudes, and secondly because he possessed an element of choice. He might select which topoi were applicable to his vita and could stress each one as much or as little as he liked. It was only that if he wished to write a formal Life, he could not avoid using them. Nor indeed had lie any desire to do so.

The influence of Classical Greek rhetoric on hagiographic style was matched by the considerable influence of the Bible on imagery, phraseology and the choice of stylistic cievice. Dut the influence of the different llooks of the Bible varied; the Poetic books of the Old Testament, particularly the book of Psalas were indubitably the most significant. Hebrew poetry lost relatively little in translation, since rhyme was virtually non-existent and effects depended upon subtle rhythm and the juxtaposition of clauses which repeated, developed or contrasted with the sense of the preceding clause. 9 puotations and images taken from Psalms are very common and easily detected. The same is not true for stylistic techniques.

6. Loparev, 'Vizantijskije žitija', p. 15 ff.

7. Velehaye, op. cit., pp. 196-7.

8. Curtius, op. cit., p. 70 .

9. See the section entitled 'poetry. Hebrev' in The Interpreter's Dictionary of the Bible, N.Y., 1962, pp. 829-38; C. F. Kraft, The Strophic Structure of Hobrew Poetry, Chicago, 1938; L. McCaw, The Poetic Books, London, 1947. 
For example, syntactic parallelism, the use of phrases and clauses which repeat, develop or contrast with preceding phrases or clauses, would seeo to be taken frov the Pealms. But sentence balance was also an important part of the teaching of the Second Sophistic on rhetoric. Indeed, as Augustine observed, there is no classical rhetorical device that may not also be found in the Bible. 10 The influence of Classical and biblical traditions cannot be neatly separated one from another, for the two strands were woven into a single thread. But since syntactic parallelism is auch more dominant in the Psalms than in Classical rhetoric, it seems reasonable to suggest that its intensive use in vitae is ultimately due to the influence of Hebrew poetry. 11

The influence of the psalms on vitae was, however, as much indirect as direct; transmitted through the medium of Christian poetry as well as drawn directly from the psalms. Christian poetry, particularly hyms, like other ecclesiastical genres were a synthesis of Judaic and GraecoRoman traditions. The earliest hyms were based on the psalms but after the adoption of Christianity as state religion, many were written to conform to the rules of Classical poetics. Such, for example, are John Damascene's poems in six-foot iambic lines. when the distinction between long and short syllables was lost in Greek, these poems lost their regular metre and became little more than rhythmical prose. And when translated into Slavonic for example, lines which originally had a regular number of syllables, now might vary considerably in length. 12 so poetry became

10. De Doctrina Christiana, III, 29, quoted by Curtius, op. cit., p. 40 . 11. See pt. III, chap. 5, infra.

12. Isosyllabic verse does exist in Old Church Slavonic. when weak jers lost their value, these too became 'prose'. See pt. III, chap. V, iv infra. 
more like prose, a process assisted by the incursions of rhetoric into poetic; wetre and rhyme vere replaced by rhyming verbal and nominal endings (also found in the psalms) and rhetoric tended to replace content in eulogistic songs. 13 furthermore prayers of supplication, repentance or thanksgiving inclined towards a freer form much closer to prose. 14 The boundaries between poetry and prose thus became more and more blurred; 15 eulogistic prose also borrowing poetic devices and effects. lagiography mainly drew on hyms and prayers. So the Hebrew poetry of the Old Testament influenced hagiographic style both directly and indirectly, and at the same time the Classical poetic tradition made its mark on the prose style of the vita.

If hagiographers required a more poetic style, they turned naturally to religious poetry, whether Judaic or Christian. It is significant that ornate religious poetry undergoes a revival in inssia in the late fourteenth century, a process coinciding with a stronger poetic element in hagiograply. ${ }^{16}$ This was further paralleled by confusion between the more purcly eulogistic sub-genres like the encomium or sluzba and the vita. 17 Lives begin to lay heavier emphasis on panegyric, and conversely, narrative begins to play a greater role in the encomium. Clearly an attempt was being wade to strengthen the expressive powers of the vita, naturally achieved by borrowing from wore poetic genres, whether hagiographic or poetic. The solution was not original: it merely repeated what was done in fourth-century Byzantium, and was mirrored elsewhere at different times. 18

13. Curtius, op. cit. p. 148, observes that this process begins with ovid.

14. Istorija russkoj literatury, ed. A. S. Orlov, V.P. Adrianova-Peretc, N. K. Gudzij, vol. I, M-L, 1941.

15. Curtius, op. cit. p. 149

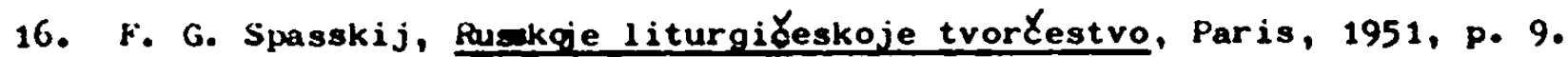

17. loc. cit.

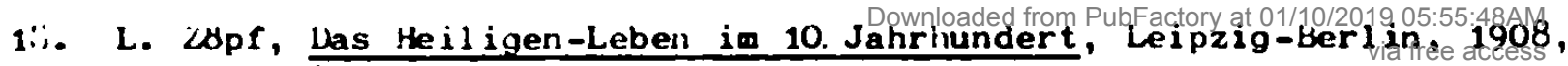
no. 7.100 
One further point should be made. A training in rhetoric was an essential part of Byzantine education. Children were taught to write school exercises in rhetorical style, often eulogistic descriptions. Rhetoric was thus the elegant clothing for all forms of literature, whether religious or secular and writers such as Nicephoras Gregoras in the fourteenth century saw nothing unusual in writing both secular and religious works in rhetorical manner. The same was not true of the Orthodox Slavs, who translated mainly religious works written in accordance with the prescriptions of rhetoric and who never had a tradition of secular education, or training in rhetoric. Consequently rhetoric was closely associated with religious literature, and far from being merely a method, tended to become associated with the religious content of these works. This meant that rhetorical ornamentation was less likely to become an end in itself, and it was perhaps easier to employ it to express sincerity and emotion. ${ }^{19}$ This goes some way towards explaining why intensely ornate prose was used so successfully by Epifanij to express his feelings in his Life of Stefan of Perm', while the more 'correct' vitae written by Nicephoras Gregoras seem dry in comparison if acimirable in their balanced construction and restrained expression. Greek Lives of this period are ornate in style but their style is much more controlled, rhetoric being employed to persuade the reader of the significance of the narrative. 20 In the Life of Stefan of Perm' by contrast, the style aims through rhythm at an emotional impact much more typical of poetry than prose, of prayers rather than hagiography.

19. One obvious exception is the indiscriminate use of high-style rhetoric in XVIth century Pussia. Another is XIVth century Bulgaria where close contact with Byzantium led to the adoption of rhetoric for varied genres. See p. 33 infra.

20. R. Guilland, Essai sur Nicéphore Grégoras. L'home et l'oeuvre, Paris, 1926, p. 175 ff. 
ii. Epifanij Premudryj, his milieu and influences upon him

1. i. Epifanij Premudryj

Many early iussian writers, being neither important historical personages nor the subjects of biographies, are destined to remain enigmatic figures. Epifanij Prenudryj is one of these. Post of the information given about his life in histories of literature is no more than supposition based on scant detail provided by Epifanij himself in his own hagiographical writings. It may be deduced that he spent many years in the Trinity monastery, founded by sergij of iladonez in the 1340s. Here evidently he wrote both his vitae, in about 1396 the Life of his friend and teacher Stefan, who became a missionary to the Permians, and around $1417-\beta$ of jergij himself. The date of his death can be guessed as around 1419 from the omission of any reference in the Life to the discovery of sergij's relics in 1421.1

But when did lipifanij first enter veryij's monastery? jince he claims to have linown sergij, he mast have arrived before sergij's death in 1391 , and he may even have been tonsured there. " wi alternative theory is that he first entered the famous monastery of Gregory the Theologian in irostov, a major centre of learning in the first half of the fourteenth century. 3 Evidence for this vien may be gleaned from his allusions to long discussions with stefan about the meaning of various biblical passayes, a testimony to the concern for truth of the two men, both exceptionally

1. hljučerskij, op. cit., p. 92 .

2. Paxorij suygests this when he says that Epifanij lived in the Irinity monastery ot samoyo vozrasta junosti, (quoted by 4 . Colubinskij, Prepodounyj sergij Thdonezshij i sozdannaja im Troickaja Lavra, M., 1392, p. 76 ).

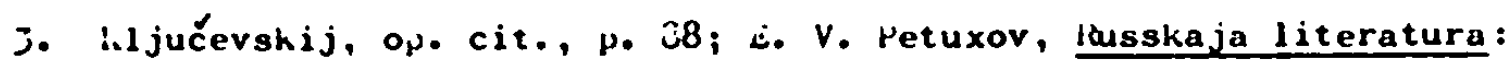
drevnij period, Jur'ev, 1912, p. 119. 
erudite for their time. 4 These discussions probably took place in the monastery in Rostov, where Stefan was resident up to his departure for Perm' in 1379.5 The possibility also exists that the two met when Stefan stopped at the Trinity monastery on his journeys between Perw' and Noscow. It is not essential to decide on the most likely alternative, for both monateries were important cultural centres where bpifanij would naturally have been in touch with current intellectual developments. He was highly regarded by his contemporaries: he became spiritual adviser to the monks of the Trinity monastery after Sergij's death, ${ }^{6}$ copied manuscripts, 7 and may also have been an icon painter. 8 However, it was his erudition that

4. A. Vaillant, 'Notes sur la "Vie d'ttienne de Perm"'l, Revue des Ltudes Slaves, XLV, Jaris, 1966, p. 34, takes this passage to mean that Stefan had received a poor theological training and being of a quarrelsome nature, (Vaillant interprets his nickname 'xrap' as meaning 'tempestueux'), argued with Epifanij when he chided Stefan for wrongly quoting the bible. However, as can be seen from pt. II, chap. $v$, Epifanij frequently misquotes in his vitae himelf, and was not in a position to correct his elder's mistakes. Moreover there is little reason to doubt that Stefan was well educated by contemporary standards; we are told in the Life that he learnt Greek as well as Permian and that much of his time in the monastery was spent studying holy books. The Kostor wonastery was noted as a theological centre. More likely the two discussed the meaning of certain passages, (see ključevskij, op. cit., p. 89). Epifanij, as can be seen from his work, was fascinated by words.

5. KljuĆerskij, op. cit., p. 89.

6. ibid., p. 90 .

7. See frontispiece and Golubinskij, op. cit., p. 102; 0. F. Konovalova, 'Pletenije sloves i pletenyj ornawent konca XIV $v . '$, TULL, $\lambda X I I, M-L .$, 1966, pp. 101-12.

8. See the letter of the wonk Epifanij of the Trinity monastery to Bishop Kirill about the icon painter Feofan Grek in Izbornik (Sbornik proizvedenij literatury drevne,j lasi), eds. L. A. Umitrijev and D. S. Lixacev, M., 1969, pp. 398-404 and the notes by O. A. Belobrova, pp. 750-1, ascribing the letter to Epifanij Premudryj. 
woet impressed them, hence his nawe 'Premuryj', the Most Wise. He was not only widely read as can be seen from his ritae, 9 but also knew Greek, a rare accomplishment in fourteanth century Russia. What is more, his Greek appears to have been colloquial. 10 This auggeats that the reference In the Dncomiue to Sargif of Radonez to the author's visits to Athos, Constantinople and Jerusalew ay indeod refor to Epifanij rather than to the later editor, Paxomij. 11 Some scholars have ascribed this rearik to Paxomij because he was known to have visited these places, but they ignore the stylistic similarities between the Encomium and the Life of Stefan of Pera'. These clearly imply that the author is Dpifanij, 12 and hence ane may infer that he had travelled, parhape spending some time on Athos. If this surmise is correct, then similarities between Epifanij's style and Serbian pletenije sloves may be more easily explained, for Epifanij could have made the acquaintance of Serbian wonks while on Athos. 13

9. Ključorakij, op. cit., p. 90.

10. Golubinskij, op. cit., p. 77, n. 2 ; G. P. Fedotor, Pussian Religious Mind, II, Harvard, 1966, p. 27. Fedotor considers Epifanij's learning superficial because he displays a knowledge of colloquial Greek rather than of Greek terms for abstract theological concepts. This ignores the purpose of a vita, which was not to promote theological discussion. It also seems very unlikely that Epifanij would have learnt spoken Greek without learning how to read as rell. He merely chose not to make his work heavy by the use of Greek theological terms.

11. Many scholars (for example I. Nekrasov, Paxoaij Sarb-pisatel' XV raka, Odessa, 1871, p. 18; I. Dujčer, 'Centry vizantijsko-slavjanskogo obsCenija i sotrudniCestra', TODL, XIX, M-L., 1963, p. 116; M. Dane, 'Epiphanius' image of St. Stefan', Canadian Slavonic Papers, $V$, Toronto, 1961, p. 79) have taken this to refor to Epifanij, and, as further proof, consider that the monk Epifanij who travelied to Jerusalem in 1415-7 was Epifanij Premuryj. If Epifanij did indeed make a pilgrimage in 1415, then this experience could not have affected the writing of the life of Stefan of Perw', sowe twenty years earlier. There is no reason however, why Epifanij should not also have visited Athos as a ach younger man.

12. infra, p. 95.

13. infra, pp. $2^{\circ}, 37$. 
Since this is only a surmise, it is well to consider whether Epifanij could have learnt Greek and become acquainted with the intellectual and literary developments taking place on Athos while remaining in Russia. In fact, the monastery in Rostov was a centre of Greek learning; its bishops were often Greeks, the liturgy was sung in both Slavonic and Greek and the library contained Greek manuscripts. Epifanij might well have learnt both written and spoken Greek there. Whether he could have been aware of current intellectual developments among Orthodox believers outside lassia, is a much more complex question which can only be answered by an analysis of cultural influences and the cultural situation in Fussia at the time. 
2. i. The religious revival in Byzantium and among the Orthodox Slavs

It is never easy to establish the extent of cultural influence, and Russia in the fourteenth century does not lend itself to simple answers.

This is because strikingly similar but apparently independent developments occurred there and in byzantium and the South Slav Urthodox countries. syzantium, Bulgaria and Serbia each underwent a religious revival in the fourteenth century (in Serbia this began in the thirteenth). The revival took a slightly different form in each area, but each was connected with the others largely through the Graeco-slav religious communities on Athos. Pussia also underwent a religious revival in the fourteenth century, but the links with the South are not so obvious. To what extent did events in bulgaria, Jerbia and byzantium influence developments in lassia? A religious movement is unlikely to be transmitted successfully from one country to another, unless the ground is prepared already. How well was the ground prepared in itussia?

2. ii. The role of Nount Athos as cultural intermediary Answers to these questions may perhaps be provided by scrutiny of the events taking place in these various countries. The movement stemmed from Hount Athos, but closely affected religious life in jerbia, Bulgaria

14. The close ties in developments in literature, manuscript copying, art, architecture and religion have been documented by a number of scholars: LixaXev, Kul'tura Husi; idem, 'Nekotoryje zadaCi', pp. 95-152; uujčev, op. cit.; M. V. Tixomirov, 'Vizantija i roskovskaja tus' ', IstoriCeskij Zurnal, 1-2, M., 1945, p. 13; idem, 'Istoričeskije svjazi russkogo naroda s južnymi slavjanami', Slavjanskij sbornik, M., 1947, pp. 166-80; M. B. LevČenko, OCerki po istori i russkovizantijskix otnošenij, M., 1956, pp. 520-32; A. I. Sobolevskij, 'Juznoslavjanskoje vlijanije na russkuju pis'mennost' $v$ XIV-XV vekax', Perevodnaja

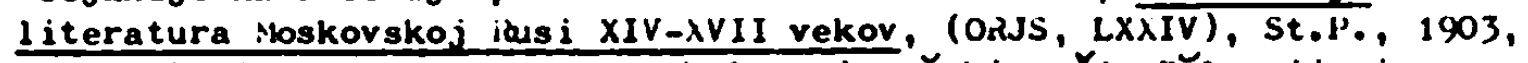
pp. 1-37; I. Snegarev, kuxovno-kulturni vrăzki we Xu Bălgarija i ilusija prez srednite vekove $\left(x-i v_{0}\right)$, Sofia, 1950; G. M. Proxorov, 'Isixazm i obXCestrennaja mysl' v vostoknoj Evrope', TUDL, XXIII, L., 1968, pp. 103 ff; G. I. Vzdornov, 'Kol' slavjanskix monastyrakix masterskix pis'ma Konstantinopolja $i$ Afona $v$ razvitii knigopisanija

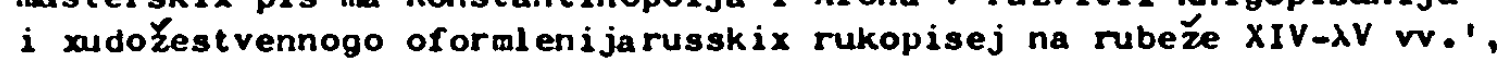
rUNL, $\ddot{X X I I I, ~ L ., ~ 1968, ~ p p . ~ 171-98 . ~ U u j t e v ~ l i s t s ~ f u r t h e r ~ m a t e r i a l ~ o n ~}$ the subject in the footnotes to his article. Faith C. M. Kitch-9783954793143 
and byzantium. It was transmitted through the medium of Greek and Slavonic monks who visited or lived on Athos. 15 Among these communities, Serbian monks were particularly numerous and from 1349 the fussian

Panteleimon monastery came under the protection of Stefan Lušan. 16 And yet relatively little attention has been paid to the role of the Serbs an athos in the fourteenth century. This is perhaps because the tradition for Serbian monks to spend some if not all their monastic lives on Athos was well entrenched by the fourteenth century. iulgarian connections with dthos in the fourteenth century on the other hand were maintained through the ecclesiastical hierarchy rather than monks in retreat. This, as will be seen, produced a different reaction to ideas circulating on thos and constantinople.

2. iii. The hesychast controversy

Situated on the borders of Bulgaria and Serbia, Athos served to draw the jlavs into the forefront of religious developments for the first time and involve them directly in a fierce controversy. irgument hinged on the nature of mystical experience and its place in the Orthodox tradition. whereas earlier the Christian mystic tradition had been practised by the few, is the late thirteenth and fourteenth centuries the movement spread and began to attract widespread support as well as opposition. The movement was given the name of Hesychasm, from the Greek hesychia meaning silence, a reference to the practice of its adherents to continuous silent

15. Their literary activity was considerable: witness the large number of Mis of bulgarian or Serbian provenance of this period. Tixomirov, 'Istoričeskije svjazi', p. 171, considers them of Serbian origin but as I. Talev shows, (Sone problens of the second south Slavic influence in russia, (jlavistische Beitrlge, LXVII), Munich, 1973, pp. 3-12), the two cannot be differentiated.

16. Tixomirov, 'IstoriČeskije svjazi', p. 171. 
prayer and preference for the erewitic life as opposed to one of ritual religion and social service. In essence, their aims did not differ from those of earlier Christian mystics, and the term Hesychasm is werely a convenient way of describing the developaents the mystic tradition in the Urthodox Church underwent in the fourteenth century. A long and bitter debate was concluded in the hesychasts' favour at a symod held in Constantinople in 1351 when Hesychasm became an officially accepted part of Urthodox theology. 17

\section{3. i. Hesychasm and literature}

The significance of Hesychasm for literature lay mninly in its stress on the moral perfection of the individual. 18 rhis led to a stronger intercst in those people who were supposed to have come closest to this goal, the saints. In byzantium 'en ce siècle, ou les querelles religieuses passionnent tous les esprits, I'hagiographie connâ̂t une suprêse et dernidre floraison: les Vies des Saints sont nombreuses, et certaines comptent parmi les meilleurs de l'hagiographie byzantine." 19 th the same time, intcrest turned to the inner religious experience as opposed to the outward show of ritual, and was reflected in the attention paid to the depiction of feeling, particularly religious feeling in the vita. 20

\section{3. ii. Hesychasm and ornate rhetorical style}

Hritinnwas conveyed through the medium of rhetoric. but there is no specific hesychast style, no special relationship between rhetoric and liesychasm. Rhetorical style had always been in Byzantium the elegant

17. J. Meyendorff, St. Grégoire Palamas et la myst ique orthodoxe, l'aris, 1959, discusses the mystic tradition and the Hesychast controversy in considerable detail.

18. K. F. Kadčenko, 'Keligioznoje i literaturnoje dviženije $v$ Bolgarii', Universitetskije izvestija, Kiev, 1898,6, p. 84.

1). Guilland, op. cit., p. 125.

20. .hoไ̌enko, op. cit., p. 125. 
clothing for all genres, hagiography included. Lives by both hesychasts and their opponents were elegantly composed. 21 It is true that ia rhétorique connut, sous les Paléologues, son dernier et brillant éclat 22 but this is not a distinguishing feature of hesychast literature alone. In fact the revival of rhetoric is usually associated with the 'Paleologuan renaissance' of interest in the Classical Greek and Roman heritage. 23 As usual in Byzantium, this interest was applied to all forms of literature. 3. iii. Hesychasm and individualism

iut though rhetoric is not a specifically hesychast form of writing, the individualism of art and literature, found in the vita as in other genres may have connections with Hesychasm. This individualism is also usually attributed to the Paleologuan renaissance. It is highly probable that the interest in the religious experience of the individual expressed in Hesychasm prompted the composition of many vitae, as well as a close attention to the inner states of mind of the saint depicted. The new individualism in art and literature and the hesychast interest in the inner religious experience should be seen as two aspects of the same phenomenon, in spite of obvious differences and contradictions. 24 This explains ladčenko's comment that the Bulgarian hagiographers ignored some of the concents found in fourteenth century byzantine ritae; the idea of individual religious freedom, 25 the reverence for friendship and the love

21. Guilland, op. cit., pp. 175, 1300.

22. ibid., p. 124 .

23. Cambridge Medieval History, IV, pt. ii, p. 196.

24. For example Gregory Palamas was opposed to the study of Classical Greek philosophy (ibid., p. 197).

25. For example, the Bulgarian Church conducted a vigorous campaign against heretics and to a lesser extent against Jews in the 1350 s. See P. A. Syrku, K istorii ispravlenija knig v Bolgarii $v$ XIV veke,pt.i, St. P., 1888-90, pp. 268-70. 
of nature. 26 These were attitudes assoclated with the human of the period, and vere no doubt instilled into all, hesychasts included, who enjoyed the customary secular education in Byzantium. 27

\section{4. i. The Blloarian Hesychasts}

In Bugaria as in Serbia, the atuation was makedly different. There was a smil group of educated hesychast supporters amidst general illiteracy and ignorance. Of course, not everyone received a good education in byzantium; peasants were either illiterate or at best received a training in the rudieents of reading, writing and religion at a local monastery. 28 Among the more wealthy classes however, a secular education was highly valued and parents mde great efforts to give their children the best education they could afford. 29 Not 80 in Bulgaria, where there is no evidence of any schools at all in the fourteenth century. The only education to be had was in monasteries and then it was of a low standard. Those who wished to study were obliged to attend Byzantine schools. Such peopl could only have been very few, but the leading Bulgarian hesychasts may be counted among them. Like their Greek counterparts most of them came from wealthy families. Teodosij (d. c. 1363), the founder of the important monatery of Kelifarevo, and leader of attacks on malpractices in the Bulgarian Church and on heretica, evidently spoke Greek fluently. He

26. Raď̌enko, op. cit., pp. 266-9.

27. Gregory Palamas, Gregory of Sinai, Philotheus, Patriarch of Constantinople 1353-4, 1364-76, Callistos, Patriarch of Constantinople 1350-3, 1355-63, all came from wealthy families and doubtless received a good education. See Syrku, op. cit., pp. 63, 72, $77,78$.

28. ibid., p. 412 .

29. J. H. Hussey, The Byzant ine Wor 1d, London, 1967, pp. 134-43. 
studied hesychast techniques with the famous wystic, Gregory of Sinai, in his Katakryowenos monastery in Paroria on the borders of Bulgaria. llere both Slavonic and Greek were used with pride of place accorded to the latter, 30 but discussions with Gregory would have had to be in Greek, since he did not know Slavonic. Subsequently. Teodosij maintained close contact with important Greek nembers of the hesychast movenent, particularly with Callistos, Patriarch of Constantinople 1350-3, 1355-63. It may be surmised that Teodosij had received some form of schooling in the Byzantine bupire, sufficient for comminication with his Greek counterparts on equal terms. It seems likely however, that he and the other Bulgarian hesychasts received a more ecclesiastically biased training than their Byzantine colleagues. This explains the absence of humanistic concepts in the vitae of the bulgarian hesychasts, and their general lack of interest in secular culture. Three other important figures all came from the same family, one branch of which lived in Constantinople and served at the Lmperor's court; Patriarch Evtimij of Turnovo (1375-93), hiprian, later Netropolitan of Noscow (1390-1407), and Grigorij Camblak, later Netropolital of Kiev $(1415-c \cdot 1420)$. $^{31} .11$ spent long periods in Constantinople and on Athos, and received a thorough theological training. 32 There is no reason to think that in religious matters they were not regarded as intellectual equals in ecclesiastical affairs by the Greek hesychasts.

30. syrku, op. cit., p. 142.

31. A. I. Jacimirski, Grigorij Camblak, it. P., 1904, p. 15.

32. Kiprian was even appointed synchellos to Patriarch Philotheus in Constantinople from 1373-5. See L. A. Lnitrijer, 'Rol' i znacenije Mitropolita Kipriana $v$ istorii drevnerusskoj literatury', TOUL, XIX, M.., 1963, p. 217. 
For the Church in Bulgaria was in a parlous condition; bulgaria itself had undergone a major decline in the second half of the thirteenth century and in the fourteenth was politically weak and physically divided. The Church was even temporarily placed under the jurisdiction of the archbishopric of Ohrid, and though it regained its autonomy from the last quarter of the thirteenth century, standards of ecclesiastical life were appallingly low; few priests were literate and many were poorly trained in ritual and dogma. 33 The task or aligning ritual with Byzantine practice, and purging texts of corruptions was initiated in the fourteenth century. 34 Indubitably the Bulgarian Hesychasts, Teodosij and Evtimij played a large role in this process. There is nothing however inherent in Hesychast doctrine that ioplies reform; movements of this nature have frequently existed totally unconnected with mysticism. 35 But hesychast interest in spiritual purification in Eyzantium did assist the revitalisation of the Church: Athanasius, one of Palamas' predecessors and Patriarch of Constantinople (1289-93, 1303-9) was much concerned with the purity of religious life, 36 and Patriarch l'hilotheus produced a new version of the Liturgy of John Chrysostom. 37 Reforms of this nature instituted in tulgaria were more thorough and far reaching because they were needed so much more there than in Byzantium. The claim that bvtiaij reformed bulgarian orthography has been conclusively disproved (manuscripts containing all the features of Evtimij's orthography predate his supposed reform), 38

33. D. Obolensky, The Byzantine Commonwealth, London, 1971, p. 244; syrku, op. cit., p. 412 .

34. KadČenko, op. cit., pp. 337-9.

35. Hanson, op. cit., pp. 175-7.

36. J. Nieyendor $f, A$ study of Gregory Palamas, translated by G. Lawrence, London, 1964 , p. 20 .

37. A. ''etrovskij, 'Istorija slavjanskoj redakcii liturgii Ianna Zlatousta', Xrisostomilia, studi i recherche intorno $\lambda$. S. Giovanni Chrisostomo, Rome, 1908, p. 886 ; K. Kern, Evxarletise, Paris, 1947.

36. See 1. Talev, op. cit., pp. 366-7. The opposite viektmay 8 be found in Lixačev, 'Nekotoryje zada $\mathbf{i}$, pprowiozled/fom PubFactory at 01/10/2019 05:55:48AM 
but there is no reason to doubt his encouragement of the copying, translating and writing of ecclesiastical texts. The connection between revitalisation of Church life in Bulgaria and llesychasm need not be denied. 4. ii. Hesychasm and Bulgarian literature

Educated Slav monks on Athos provided translations of Orthodox literature previously unavailable in slavonic, in particular the teachings of the most important wystics. Some of these required a firm grasp of the subtleties of theological debate on the part of the translator, but these Slar translators from Athos proved equal to their task. 39 Lives of saints also required revision; the lives of four Bulgarian saints existed only in rudimentary form. Patriarch tvtimij set about this task. four simple Lives of bulgarian saints were re-written in the structural pattern typical of formal Byzantine vitae, in rhetorical style and with artificial syntax based on Greek. Since all four saints had long been dead, the freshness of detail found in some contemporary Lives of hesychast saints is lacking, but non-historical material was added to suggest that the four had hesychast leanings. 40 The vitae also reveal some of the same interest in the inner life and emotions of the saints as in contemporary byzantine Lives of hesychast saints.

Evtimij composed both vitae and encomia. All are admirable examples of the strict application of hagiographic canons. They, as well as those written by his relative Grigorij Camblak, reveal a mastery of rhetorical ornament, rendering them equal to the best examples of byzantine

39. N. G. '̉opruženko, 'Iz istorii religioznogo dviženija $v$ bolgarii $v$ XIV veke', Slavia, VII, Prague, $192{ }^{\prime}$, p. 545.

40. Kadčenko, op. cit., p. 274. 
hagiography. 41 Whetoric was also used to affect emotionally by the use of various forms of rhythm and rhyme. Evtimij carefully moderates these effects, confining them mainly to the concluding sections of his vitae and to his encomia. This does not alter the basic panegyric tone of his vitae, an effect Radč́enko noted was also typical of lireek hesychast Lives. 42 This tendency, when exaggerated weant the intrusion of the traditional rhetorical effects of panegyric genres into the formal vita; a tendency paralleled in Russia.

But the word-weaving of the Bulgarian hesychasts was not an exclusively ecclesiastical style; both the Slavonic translation of Manasses Chronicle and gramoty are composed in pletenije sloves. 43 Evtimij's style should be viewed as a combination of firstly, his hesychast interest in the saintly individual leading to vitae with a strong emotional and panegyric tone, and secondly his desire to see the Church revitalised. This prompted his activities as patriarch, his encouragement of ecclesiastical culture and writing of Lives of Bulgarian saints in the style that had always becn considered the most suitable.

\section{5. i. Leligious and cultural developments in X111th century Serbia} jerbian cultural traditions contrast with those of bulgaria. In the fourteenth century, the Serbs took less part in the Hesychast controversy than the Bulgarians and their role in cultural and religious developments has as a consequence been underestimated. The Bulgarians strengthened

41. Grigorij Canblak is claimed both as a kulgarian and as a Rumanian. He also worked in serbia and Pussia. He should consequently be regarded as a symbol of the community of interest among Orthodox Slavs and tumanians, an international writer, whose interests were not national ones. He is mentioned here in connection with Bulgaria because of his links with Evtimij's school.

42. jyrku, 0.2. cit., p. 266.

43. ralev, oj, cit., pp. 33-7, 4i2-59. 
the autocephalous bulgarian Church, reinforced its hold on the country, founded monasteries and encouraged translation and copying of ecclesiastical literature, all in the fourteenth century. The Serbs however, had begun this process a century earlier (if somewhat less energetically). They too struggled for the autonomy of the Church and attempted to develop strong cultural traditions. They too undertook a revision of liturgical manuscripts and the preparation of a full range of Church literature, including Lives of national saints. Athos played a significant role in this development, for it served as a seminary for Serbian monks. The jerbs had their own monastery, Chilandari, to which was attached the Kareia hermitage founded by $S t$. Sava at the end of the twelfth century. They were also resident in the monastery of St. Paul and after jtefan Dušan took the lassian Panteleimon monastery under his care in the midfourteenth century, became members of its Orthodox Slav community. Apart from their theological training, Serbs also took advantage of the cultural facilities provided on Athos. The most easily accessible sources of manuscripts for translation were the rich libraries of the Greek monasteries on Athos. 44 Not surprisingly therefore, wost of the copying and translating of manuscripts intended for use in Serbia was undertaken by Serbian monks resident on Athos. 45 In the fourteenth century, Athonite monks of Serbian origin were still translating texts from Greek for both Serbs and Bulgarians.

\section{5. ii. Athonite nysticism and Serbian hagiography}

There are also close links between the contemplative life and cultural activity. The Kareia hermitage, which was a retreat or isichastiria, is

44. V. Mošn, 0 periodizacii russko-jułnoslavjanskix literaturnyx svjazej X-XV vv.', TOVL, XIX, Ni-L, 1963, p. 85.

45. Hew manuscripts are extant for the thirteenth century, but references in original works suggest that there were many more. See ros in, op. cit., p. 86 . 
described in Serbian manuscripts as a centre famed both for the copying of manuscripts and independent literary work. The heads of the hermitage were often writers and they trained young monks in the art of copying and translation. 46 The hesychast form of 1 ife was practised at the same time and combined with a communal ife devoted to humility and poverty. In spite of Callistos' statement that mysticism was in decline wen Gregory of Sinai arrived on Athos at the end of the thirteenth century, it seems likely that centres like Kareia were flourishing. It is possible that Gregory's method of prayer was unknown, but less likely that it did not meet with a sympathetic reception from practising mystics. Gregory hiaself notes the high level of ascetic contemplation among the monks on his arrival, and Callistos' statement should be seen as a desire to exaggerate Gregory's achievements. 47

A close link can thus be established between mysticism and literary activity among the Serbs on Athos. This is not surprising, for the contemplative life would seen naturally conducive to the production of religious literature of a high standard. The Serb Lomentian who came from the hareia hermitage, 49 revealed in his vitae his veneration of the saintly individual and an intense religious feeling. The method he used to convey these feelings was in essence the same rhetorical style that had always been used for the literary vita. But Uomentian's exclusively monastic training had acquainted him only with religious literature, in particular with religious poetry: the Psalms were read every day in his wonastery, and prayers and hyms were an unfailing part of his daily routine. Not

46. ibid., p. $36-7$.

47. ibid., p. 92 .

48. As Jomentian himself says in the postscripts to his Lives: Life of java, p. 345, Life of Simeon, p. 117, in Zivot sv. Simeuna i sv. Save, ed. $U_{j}$. DaniCic, Belgrade, 1865. 
surprisingly, he drew on these poetic traditions for greater force of expression, and not obliged by a secular training in rhetoric to keep within set bounds, created works rarely equalled in Slavonic hagiography for length and poetic effusireness. Dasentian's efforts to convey the spirit at the expense of form are strongly reminiscent of Epifanij's. Although there are some differences in their approach, the similarities are so marked that they cannot be ignored. 49

The influence of Serbian monks on Athos does not decrease in the fourteenth century but they took less part in the doctrinal and political struggles surrounding Hesychasm than the Lulgarians, and so fade into the background. 50 The hesychast controversy was slow to produce an effect on religious or cultural 1 ife among the serbs, 51 and hesychast influence may only be discerned in the attitudes and interests of the Serbs who had trained on Athos, and not in any precise programue.

\section{Hesychasm among the Jerbs and bulgarians: conclusions}

Two trends may thus be discerned within Hesychasm. The first of these is centred on the hermitages of Athos and is expressed in a profound spirituality and extreme otherworldliness. It provided a favourable climate for writing as may be seen in the activities of the Serbian colony on ithos in the thirteenth and fourteenth centuries. The second trend

49. See pt. II, chap. i, infra.

50. Whe of the most famous hesychast monks lsaiah, for example, was close both to l'atriarch Philotheus and to the serbian court, but his part in Church politics remained limited (unlike for example tivimij's), because he remained on Athos as abbot of the Pussian ranteleimon monastery. See proxorov, op. cit., p. 97. Holin also stresses the strong two-way cultural links between bulgaria and Serbia (ibid. pp. 93-4). See also 'ulić, 'Serbskije agiografy'.

51. Ubolensky, op. cit., pp. 303-4, discusses the influence of hesychast traditions in serbia. 
emerged in the fourteenth century when the controversy over Hesychasm forced the movement out into the open. From a concentration on contemplative monasticism, Hesychasm transferred its sphere of influence to the world of ecclesiastical politics and the social aspect of the Church's work. Leading hesychasts occupied the highest posts in the Orthodox Church. Host of them had trained on Athos, and evidently retained their respect for those who preferred mystic contemplation, while feeling that their duty and interests lay with the life of the Church as a whole. The Bulgarian hesychasts belonged to this group, and their closest connections were with their counterparts in Byzantium. There was constant interaction between the two aspects of Hesychasm: leading figures returned occasionally to nthos or other monastic retreats for periods of mystic contemplation, to renew contact with the ancient mystic tradition. The two should not be regarded as mutually exclusive, although the distinction is still useful as a means of explaining the varied activities of hesychast auherent s.

\section{7. i. The second jouth Slavonic influence in russia}

Just as Hesychasm may be divided into two parts, so too cultural developments in tussia riust be separated one from another. Niddle bulgarian orthography, linguistic features, manuscript ornawent, revision of the liturgy and other formal changes were imported by bulgarian-trained scholars, such as Kiprian and Grigorij Camblak and by the Serb Paxomij. They reflected bulgarian practice. 52 These largely formal changes which have little to do with lesychasm can without reservation be termed the 'Second jouth Slavonic influence'. But they mast be kept distinct from developments in other fields.

52. Lixačev, 'Nekotoryje zadači', pp. $96-8$, summarises these changes. 
7. ii. The second South slavonic influence in art

Thus Pussian art of the period reflects the interest in the indiricul and motional impact typlcal both of the Paleologuan renaissance and Hesychase. But these ner trends, though coning from the South around 1330, did not originate in Bulgaria. Groak artists worked in Pussia in 1334 and again in 1338 and 1345,53 apparently training Puss lans in the ir methods. 54 In the third quarter of the century, Feofan Grek arrived in Pussia to commence thirty years of artistic creation. His contacts with Pussian artists auch as Publev proved mutually rewarding. 55 Serbian artists are also present in numbers in Pussia at this time, working particularly in Novgorod. 56 Their work displays the same tendencies as those of the Greeks and reflects the inspiration by Athos of their cultural revival a century before bulgaria. Though clearly part of a second South Slavonic influence, artistic developments, brought by Serbs and Greeks, mast be separated from the formal changes brought by Bulgarian trained scholars.

\section{1ii. The second South Slavonic influence and Eoifanij Prewaryj'a pletenije sloves}

In the past Epifanij Prewudry's pletenije sloves has also been ascribed to the influence of Ertimij's school transeitted through the South Slav scholars who went to Pussia after the Ottoman conquest of Bulgaria and Serbia. 57 This view has been invalidated, for Epifanij wrote

53. Lixačr, Kul'tura Pusi, p. 35 .

54. ibid., p. 118 .

55. ibid., pp. 119-22.

56. Lixačer, 'Nekotoryje zadači', pp. 1014; idem, Kul'tura Rusi, pp. 36-7.

57. For example, see A. S. Orlor, Dremiaja russkaja literatura XI-XVI VV., M-L., 1937 , p. 187 . 
his Life of Stefan of Perm' around 1396, too early to be influenced by South Slav scholars, who, with the exception of Kiprian, arrived after this date. Dinitrijev has shom conclusively that Kiprian's om style is much simpler and more factual than bpifanij's and could not have seriously influenced him. 58 The style of bulgarian pletenije sloves was never so ornate as Epifanij's, and if foreign influences are to be sought for his style, then it would be wiser to look towards Serbia.

Apart from parallels in approach and style between tpifanij and Domentian, one fact suggests that he was actually acquainted with Serbian vitae: the presence in the Life of Stefan of Perm' of a rhythmic prose pattern developed from a passage in Stefan Prvovenčanny's Life of simeon. 59 It is probable that Epifanij read Serbian vitae during a visit to dthos since there is no proof of the existence in Pussia of Serbian Lives other than the Life of Sava. 60 on the other hand, it should not be ruled out that copies are no longer extant. But whatever the influence of Serbian Lives, the greatest credit for Epifanij's pletenije sloves must go to the spiritual wilieu in which Epifanij lived and worked in itussia.

\section{3. i. Ihe religious revival in xivth century idssia}

sround 1330 a lively hermit tradition sprang up in kussia. Monks and lay people left the towns for a life of contemplation in the wild

58. Daitrijer, 'Hol'i značenije Mitropolita Kipriana', pp. 236-54; h. Meče, Grigorij Camblak. Sofia, 1970, pp. 230-45, considers that the Life of Sergij of kadonez was influenced by Kiprian's Life of Peter and that both the Life of Stefan of Perm' and of Sergij of Kadonez were influenced by Bulgarian literary traditions. Unfortunately most of his examples are topoi of byzantine, not Bulgarian, origin. His views therefore need not be taken seriously.

59. A. V. solov'ev, 'epifanij Jremudryj kak avtor "slova o Zitii i prestavlenii velikogo knjazja Lnitrija Ivanoviča, carja russkogo'"', IUIL, XVII, N-L., 1961, p. 105.

60. iošin, op. cit., pp. 100-1. 
countryside. Of these the most famous was Sergij of Radonež, whose retreat later developed into a famous Muscovite wonestery, the Trinity monastery. Here Epifanij himself lived and worked. Sergij was the 'interlocutor' of some wembers of this wovewent, but the new movement seems to have sprung up independently in a number of different places, including remote parts of Novgorod territory. 61 soon disciples joined the first hermits, and monasteries grew up, devoted to the principles of a cormunal life of poverty, humility and contemplation. As a result, up to eighty monasteries were founded in North East lassia alone in the fourteenth century, and a further seventy in the first half of the fifteenth. This compares with a figure of up to ninety for the three preceding centuries $(X 1-X I V t h) .62$ The reasons offered for this amazing growth of wonastic life ere the turbulence of life in Rusian toms at the time and the decadence of urban monasteries. These are scarcely adequate to explain such a reaction, although it is impossible to pinpoint the reasons for ach an exodus at this time. The development of eremitism so closely corresponds to events in the south that it my be wondered whether there are any links. To attribute the whole ibssian movement to the influence of Athos or of South Slav monks is absurd, but there is evidence for suggesting that hesychast ideas did not go unnoticed in lusssia.

8. ii. Links between Hussia and Hesychasm in Greece and the Balkans Apart from the Greek connections of llostov, 63 two monasteries in Moscow were known to have links with byzantium, the Bogojavlenskij monastery ${ }^{64}$ and the Nikola Staryj monastery, a refuge for Greek monks

61. Fedotor, op. cit. II, pp. $197-8$

62. LevKenko, op. cit., p. 531.

63. Tixomirov, 'Vizantija i Moskorskaja Mus'', p. 13.

64. Levčenko, op. cit., p. 532. 
visiting russia on Church business, and probably also linked to a Greek trading colony in Moscow. 65 Metropolitan Aleksij (1354-78) knew Greek and his predecessor Theognostos (1328-53) was himself a Greek. Another monastery founded by Sergij of Kadonež's nephew, the Simonov wonastery was a stavropigia, in direct subjugation to Constantinople. ${ }^{66}$ other monks came from Athos to found monasteries in Hussia, 67 and the Bugarian hesychast Kiprian, whose clain to the metropolitanate of Noscow had been finally consolidated by 1390 was naturally sympathetic to increased contacts with Athos, Constantinople and South Slav countries. Some of these visitors must have known the out 1 ines of the hesychast controversy and communicated them to their kassian colleagues. A few may even have been hesychast supporters themselves. Further, decisions of the synods of 1341,1347 and 1351 mest have been communicated to Russia.

Contacts were not restricted to visitors to fussia from the South; pilgrimages and journeys to the Bycantine capital or to Athos appear to have been common. Wetropolitan Aleksij was in Constant inople in 1357 returning with a Greek icon, and Alanasij Vysockij, founder of a monastery in jerpuxov and friend of Sergij of .acioneź, spent the last years of his life $(1387-1401)$ in the Studite monastery in Constantinople. ${ }^{63}$ Like Kiprian, who also spent some time in this monasterv, Afanasij copied manuscripts for iussia. Furthermore, his selection of texts reveals an interest in

65. Tixomirov, 'Vizantija i Moskovskaja Has'', p. 10.

66. ibid., p. 13.

67. For example in Moscow, on Muraransk island on Lake Onega (Levčenko, op. cit., p. 531). The first abbot of Spasokamennyj monastery on Lake huben, vionysios, came from Athos during the reign of Dmitrij ionskoj (fedotov, op. cit., II, p. 257).

68. Uujěer, op. cit., p. 115, suggests that Afanasij may have moved to another famous monastery, the Peribleptos, before his death. 
the urystical literature highly valued by the hesychasts. Preeumably his interest was shared by many participants in the eremitic wovement in Russia, and this can be confirmed by noting the large amount of aystical ascetic literature translated at this period. 69

Vitae and other sources also refer to the practice among some wonks of molčanije, the slavonic translation of hesychia ${ }^{70}$ and it is noteworthy that, as on Athos, there is a connection between the development of monasteries of a communal type favoured by the hesychasts and the contemplative life. But is it realistic to talk of a hesychast tradition in lassia in the late fourteenth century, when a theoretical exposition is provided only a century later by Nil Sorskij? The answer most probably is that a small number of people were familiar with hesychast prayer as a result of prolonged visits to Athos or secondary centres or from instruction by a teacher trained in the method. Many of the hermits of the fourteenth century, especially those not attached to a particular monastery probably never received any expert instruction, and even where teachers existed it is unlikely that they found many disciples prepared to follow such rigorous training. The hesychast Jesus prayer may have been in use in the Trinity wonastery, but there is no direct evidence of this. The vita of Pavel of Obnora, who died in 1429 states that Pavel, a disciple of Sergij of kadonež knew it, 71 but it is possible that he leamt it only

69. A. S. Arxangel'skij, Tvorenija otcov cerkvi $v$ drevnerusskoj pis' mennosti, St.P., 1883, pp. 136-7. G. M. Proxorov, 'Kelejnaja isixastskaja literatura (Ioann Lestvičnik, Avra Dorofej, Isaac Sirin, Simeon Novyj Bogoslov, Grigorij Sinait) v biblioteke Troice-Sergijevoj lavry c XIV po XVII V.', TODL, XXVIII, L., 1974, pp. 317-24, has shown that, judging by the numbers of HSS of Byzantine mystical literature in the library of the Trinity monastery, an intense interest in aysticisa developed in Russia in the late XIVth century and reached a peak in the $1420 \mathrm{~s}$ and $30 \mathrm{~s}$.

70. Proxorov, 'Isirazo i obł̌estrennaja mys1'', p. 1078 pp. 103-7 cite a number of examples of an acquaintanceship with hesychasm in iussia.

71. 1. Smolitsch, Leben und Lehre der Starzen, Vienna, 1936, p. 57ff, quoted by $\lambda$. J. M. Lavids, 'Nil Sorskij und der Hesychasmus in louss-

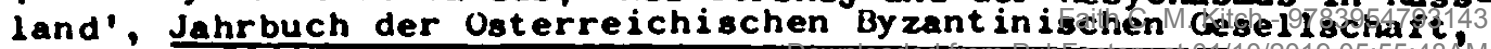
XVIII, Vienna, 1969, pp. 176-7. 
after leaving the Trinity monastery.

Links between Hesychasm and the eremitic movement in Iussia certainly exist, but they are insufficient to prove the use of hesychast techniques in tussia at this early date. Clearly attested is a lively interest in the ascetic and mystic movewents in the south among members of a spontaneous native hermit tradition. Their interest was fostered by contacts with ithos and Constantinople. Pilgrims returning to idssia brought information or expert instruction about hesychast ideas and technique, or arranged for copies of mystic and ascetic works to be sent to assist the hermits and their disciples in their spiritual endeavours. The influence of formal liesychasm was probably uneven and its concepts often poorly comprehended, but it encouraged the development within monasteries of a dussian mystic tradition. Like llesychasm, this tradition was only clearly formulated when it attracted serious opposition. It was nearly a century afterwaris that Nil Sorskij elaborated the teachings of the Hussian mystics in a way that showed he had fully absorbed Orthodox traditions, and proceeded to defend the mystics and their ideas of non-possession from the attacks of losif Volockij and his suiporters

but at this staue, a century earlier, ussian mysticism is just beginning, and it is wiser to talk of a religious revival which emplusssed asceticism and contemplation. This movement was not the result of hesychast influence, although it benefited from contact with it. The two movements were similar in many ways; both provided a favourable climate for religious literature. Both encouraged contemplation which was linked to a monatic life devoted to the principles of poverty, humility and communal life. Un athos and in the Irinity monastery, this type of religious life encouraged the developwent of cultural traditions: the hareia retreat, part of the serbian Chilasdari monastery, trained copyists and 
produced the best writers of mediaeval Serbian literature. The Trinity monastery sheltered both Lpifanij Premudryj and Andrej laublev and fostered manuscript copying and ormamentation. The concern for the improvement of religious life in Hussia led to the eager adoption of the formal changes and reforms brought by the South Slav scholars.

Clearly therefore, the cultural atmosphere in the Trinity monastery was sufficiently close to that of the Serbian monastery on Athos to explain Lpifanij's adoption of an ornate style similar to that of Serbian hagiographers. Like them, Epifanij had an exclusively ecclesiastical education. He may have been influenced by serbian pletenije sloves but his initial inspiration case from the milieu that formed him in fussia.

\section{A note on the term pletenije sloves}

The style in which Epifanij Premudryj wrote, pletenije sloves, has been mistakenly assumed to have been coined to refer precisely to Epifanij's style. Malik Nulić however, traced the connection between wearing (pletenije) and praise back to the laurel wreaths awarded to military heroes in ancient Greece. 72 The phrase 'to weave words' meaning 'to praise' was known before the fourteenth century. Epilanij refers to his style as:

$$
\text { слово ппетвия и слово плодящи, } \quad \text { (f. } 770 \text { v.) }
$$

but he is using a term found in the Slavonic translation of early Byzantine hywns:

слово плетуще словесъ сладкопьни

72. Mulic, 'Pletenije sloves i hesihazam', p. 143.

73. ibid., p. 144, quoted from lestal Menaion, Jan. 7, 4th ode, supplementary heirmos. 
Other examples may be found in original literature, as in the fourteenth century bulogy to the Bulgarian Taar loan Alekanghra:

\section{вззте радостние похввлы сзплеты емоу рекоу}

The striking feature of Epifanij's style was its intricate eulogistic language, so distinctive that it deserved a special term. Nevertheless, it is one that can also be applied to Evtinij and vomentian's panegyric style.

\section{Conclusions}

Thus neither the term pletenije sloves nor ornate rhetorical style are new, but the way in which the style is employed in this period represents a new departure for Orthodox Slav hagiography. Pletenije sloves was created in a specific cultural milieu. But even within pletenije sloves there are differences, resulting from the hagiographer's own conception of his task. This conception relates to the milieu in which he lived and worked, and, together with personal preferences and differing indigenous traditions 75 generated subtle differences of approach and style. These comprise the subject of investigation in this thesis.

74. In loan Aleksandär's l'salter (sometimes called jofijski pesnivec), quoted by C. Vranska, Stilni poxvati na latriarx Lvtimij. Sofia, 194i, p. 74 .

75. Lixačev points out that this period of lussian history, that of the rise of Moscow, saw a return to the cultural traditions of Kiev. It was reflected in the conscious initation of Kievan works as well as quotation (see Kul'tura lusi, pp. 11-2, 18-9). Though in general this is true, it should not obscure the fact that hagiographical style was basically the same in all high style vitae, whether original or translated. All hagiographers were bound to this style though undoubtedly particularly influenced by popular and ensily accessible native works. 
PART T $T$ O

STRUCIURE AND COMPOSITION

Studies in distinctive aspects of the Life of Stefan of Perm' 
The structure of the Life of Stefan of Perm', like other aspects of the work may only be elucidated by reference to hagiographic convention. 1 In accordance with traditional models, the hagiographer begins with an exordium of variable length and complexity, using the 'comonplaces' of classical poetics. ${ }^{2}$ Following the traditional captatio benevolentiae, he explains that it is his duty to preserve the saint's memory for the edification of all, and realising this, he has tried to overcome his own unworthiness and poverty of education; God, he hopes, will assist him. Sometimes, commonly in Greek vitae, a parallel is drawn between the author and the slothful servant of the New Testament parable. Finally the author may relate how he has gathered his material. This is usually the only section where the author supplies any information about himself.

The exordium is succeeded by the body of the work, a chronological account of the saint's life. Any number of the following motifs may occur, depending on the type of saint. This section starts with mention of the saint's pious parents, his birthplace, and name. He is either dedicated to God at birth or marked out at an early age, perhaps by fasting on bednesdays and fridays while still an infant. le is usually an intelligent and pious child, but sometimes only makes scholastic progress after cod has granted him the gift of study. saints rarely marry, vigorously resisting pressures from their parents. The next stage is an account

1. This article has been published in slightly modified form under the name Faith $C_{\text {. }} M_{0}$. wigzell, and title 'Convention and originality in the Life of Stefan of Perm': a stylistic analysis', in Slavonic and isst European Keview, XlIX, no. 116, London, 1971, pp. 339-55.

2. Aristotle, Cicero and Wuintilian all encourage the writer to use topoi. For further informgtion about topoi present in the intro-

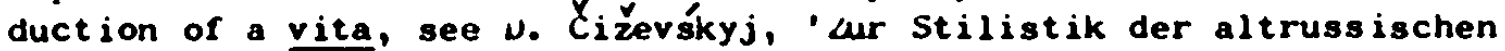
Literatur. ropik, Festschrift fur Max Vasmer, (Slavische Verdffentlichungen, IX), iesbaden, 1956, pp. 105-13. 
of the subject's achievements in life (ascesis), which vary according to the type of saint. Purther developwents depend on this but certain motifs appear regularly. If, for example, the saint is asked to accept a position of responsibility, as bishop or abbot, he will only accept reluctantly, but, once in agreement, he is always elected unaniwously. Miracles performed curing his lifetime are included here. The saint frequently predicts his own death, delivering a farewell sermon to flock or brethren on his deatlibed. His grave is marked out in some way: a light seen above it, angels singing, or a sweet smell emanating from it. The account of posthumous miracles (a vital element in the recognition of his sanctity) and the translation of his relics conplete this section.

The vita ends with a panegyric, where the author compares the saint with biblical figures and asserts his place in the ranks of the blessed in heaven. He offers a prayer to the saint for the reigning monarch and another for intercession in times of need. He may also add a personal note; a plea for tolerance from his audience, and a further reference to his sinfulness and lack of talent. 3

In sijite of this formal strait-jacket, differences even in rhetorical vitae of the same functional type are often striking. ind these differences are more than superficial, for in exercising his choice of structural motifs, the hagiographer inadvertently revealed his own concept of hagiography. Vivergence of approach to construction, length, characterisation, and narrative all tell of his ideas on the literary realisation of sanctity. Furthermore, external factors sometimes provided hin with technical problems. Epifanij faced three such problems:

3. This scheme is based on Loparev ('Vizantijskije Kitija, pp. 15-36), but takes account of translated Greek and original Slavonic vitae. 
firstly, Stefan as a missionary saint was a rarity in the Orthodox Church, 4 secondly, he had not yet been accepted as a saint at the time of writing, 5 and, thirdly, he had not performed any miracles, the wost common prerequisite for sainthood. As a result extra efforts had to be made to make the life convincing, and these too are reflected in structure, style, characterisation and narrative technique. It will be seen that these complewent rather than clash with Epifanij's concept of hagiography.

The basic structure resembles that of conventional vitae. The abstract introduction contains all the usual topoi, iexcepting the reference to the slothful servant). 6 The central narrative section begins, as expected, by mentioning Stefan's pious parents and his childhood in the town of Ustjug. As a child he shows scant interest in childish pastimes, preferring study and worship. As a young man he enters a monastery, where his piety and leaming again mark him apart. Some time later he fulfils a long-felt wish to embark on a mission to convert the pagan Permians (now known as Lyrians or howi). Then follow descriptions of Stefan's missionary activity, the building of a church, teaching of the people and the creation of a Yermial alphabet. He foresees his own death, and delivers the usual farewell sermon. Thus far, although the ascesis is unusual, the Life does not appear very different from other vitae intended for private reading. In the absence of miracles however, cipifanij had to devise a conclusion to crown his work. The resulting three lawents drew heavily on the byzantine funeral oration, and like

4. St. Cyril offers an obvious parallel to Stefan, but whereas the Vita Constantini was composed for Slavs, the life of stefan was not intended for the people who owed their baptism to Stefan. This was a serious problem for Epifanij.

5. Stefan was not in fact canonised until Makarij's great council of 1547.

6. Čǐevśkyj, 'ur stilistik', p. 108. For a detailed analysis of cyifanij's treatment of the humility topos, see pt. II, chap. ii, infra. 
thes combine lamentation, prayer and panegyric. 7 Their pathos and

lyicter make ther the nat woving part of the work.

This brilliant solution to the problen is unusual, but does not in itself explain how wuch this vita differs fro others. The nost distinctive etructural feature of the work is its length. Comparod with other vitae of the sane type, auch as Nestor's life of Feodoeli, the Life of Stefan of Pere' is exceptionally long, and yet does not offer a correspondingly nller account of Stefan's life. Factual informetion constitute only a tiny proportion of the whole 8 what remins is repetition, eulogy, prayer and digression, all in the gorgocusly convoluted style of pletenije slores. Recent critics, subscribing to the riew that 'as soon as prose becoses more emotive than scientific, the forml side becoues proeinent', 9 have shown that the rhytheical style and resulting length of the work stem from Epifanif's desire to evoke veneration of Stefan. But they etill have not examined closely the old accusation that factual detail and wents are dromed in a plethora of words. 10 Citerskij alone observes that 'Kljucerakij is the anly one who justly,

7. J. Holthusen, 'Epifanij Prequdryj und Greoor von Nyssa', Festschrift Itr Mrgarete Holtner, Heidelberg, 1967, pp. 64-82, shows that they are based on the funeral oration and that the lament of the pormian Church is a reworking and applification of Gregory of Nysea's Funeral Oration to Bishop Meletius of Antioch. He supports the suggestion of Filaret that this Laent any have been corposed as an independent work on the ground that it is coeplete in itself and does not conform to the conventional atructure of the rita (op. cit., p. 68). The save is however, true of the lament of the Permian people. Even if composed before the rest of the life, the lament of the Peraian Church was clearly intended as an integral part of the three-fold conclusion.

8. D. S. Lixačer, 'Izobraženije ljudej r žitijnoj literature XIV-XV $r v \cdot$, TODL, M-L., 1956, p. 108, gives the proportion as one fiftieth of the total.

9. I. A. Richards, Principles of literary criticism, London 1967, p. 104.

10. See p. 10, n. 3, particularly Ključevskij, op. cit., p. 112. 
though briefly, notes the value and imposing factual content of the Lives written by Epifanij', and goes on to discuss it in more detail. 11 In a recent article, honovalova pointed out that the criticisa of the lack of factual content in the Life applied only to biographical data. 12 Epifanij left out information about Stefan's early life, which as an old friend he would certainly have known, because he had to approximate his life to the saintly ideal represented in the pattern described earlier. Neither Kiževskij nor Konovalova however, seriously examines why some facts are given in detail and wat role they play in the work. 13 Some vitae contain wech factual information about a particular historical situation or problem. The hife of wilfrid for example, is a valuable source for the history of the Church in seventh-century Bngland, 14 and Teodosije's Life of java for the formation of the Serbian empire and autonomous Church. Sometimes this detail is superfluous to the main purpose of a vita, thus reflecting the author's ow literary ideas, Schwaus showed this clcarly when he discussed how Teodosije tried to place Sava in a specific temporal and physical setting, and contrasted this work with Jomentian's Life of sava which placed his life in a symbolic sphere. 15 The Life of Stefan of Perw' furnishes very little information about Church and state in fourteenth-century fussia: jtefan spent much of his life

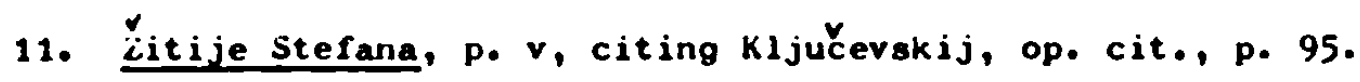

12. Konovalova, 'Princip otbora'.

13. Nanson, op. cit., p. 142, characterises the life of Stefan of Perm' as 'a unique example of scientific Pussian hagiography'. This ignores the role of the digressions.

14. by Eddius Stephanus in Lives of the Saints translated by J. F. Webb, London, 1965, pp. $131-206$

15. A. Schmaus, 'Die literarhistorische Problematik von Domentians SavaVita', Slawistische studien aum V. internationalen Slawistenkongress in Sof ia 1963, Gottingen, 1963, p. 130. 
outside Russis anyway. Nor can auch be learned of the process of fussian colonisation in the fourteenth century, as Ključevakij found to his regret. Obviously, this was not of assistance to Epifanij in creating a picture of sanctity, just as Domentian deliberately ignored historical material.

Veither biographical nor historical data therefore are present in the Life of Stefan of Pera' in anything more than the detail expected of the conventionalised vita; much 1 ess in fact in proportion to its length. There is however a mass of information about Perm', its people, their customs and beliefs. This can best be illustrated by examples from the Life itself. barly in the work, bifanij tells of Stefan's preparations for the mission to the Permians: his study of the language, composition of an alphabet and translation of 'the Books' into Permian. He then digresses to describe the geography of the land of Perm', the peoples who live on its borders, and the rivers that flow through it. This description is highly detailed for any vita, let alone for one presumed to shun factual information. Epifanij selected these particular facts to fit in with his literary aims. If he were to convince a lussian audience unaware of the existence of Perm' that a missionary who had converted an insignificant tribe was worthy of canonisation, he had to render the setting for Stefan's exploits as concrete as possible.

A similar idea lies behind the use of narrative in the Life, where Epifanij reveals great artistry; 'he presents pictures wich, by their breadth and by the brilliance of their separate details, deeply impress the consciousness of the reader and are retained in his memory."16 Vivid narrative is restricted to the description of the mission, the ascesis,

16. Č́iževákij, ̌̌itije Stefana, p. xi ii. 
which becomes doubly important as no miracles have been performed. Par. ticularly impressive is the use of lurid detail that enlivens the accourts of the Permians threatening to kill stefan:

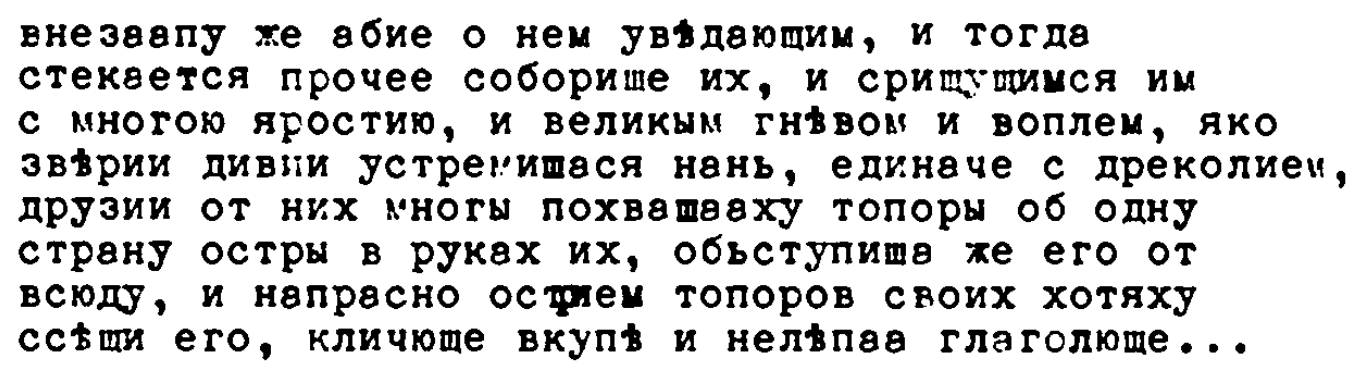

(f. 680 v.)

rurther examples are found on folios 672 and 673 . In every case the reader is left in suspense, pondering the outcome, while Epifanij goes on to draw parallels with similar situations in the book of psalms. ${ }^{17}$ The example quoted is followed by a prayer, largely comprising lyrical excerpts from Psalms; an emotional plea for deliverance. In all three cases, these sections are far longer than the picture of the menacing Perrians. The reader, who is not told of the outcome of events, is left to assume that itefan emrrges unscathed, as in the example quoted, wherc Stefan's subsequent sermon to the fermians presupposes his escape. The use of digressions and prayers to break the narrative might appear a fault in narrative technique, but the main purpose of the vita was of course the depiction of sanctity, not dramatic tension. The vivid narrative creates a concrete picture in the minds of readers, onto which Stefan's spirituality, stressed in prayers and digressions, might be superimposed. Important as the narrative is, it must never dominate the portrayal of a saintly figure. The diụressions are therefore ultimately more inportant than the dramatic episodes.

It later turns out that there is another reason for the inconclusive ending to these episodes. The jermians are an unaggressive people who 
never attack first. What they are trying to do is to provoke Stefan into attacking them. Epifanij does not mention this at the tiwe, since to do so would destroy the impression of savagery so carefully created to reveal Stefan's courage in standing fearlessly against attack, and thus produce an anti-climx. By saving this second reason till later, 18 he is able to turn it to his advantage, explaining that Stefan's forbearance and gentleness (qualities the Permians auch admire) have convinced them of his moral superiority, and thus led to their conversion. Vivid narrative makes further demands on Epifanij; he has to attempt a treatment of character unusual in hagiography with its typically mediaeval failure to examine motivation. Usually the only character in a Life is the saint, wo is entirely good: other characters are shadowy and peripheral, since they my not draw attention away from the central rigure. 19 Occasionally an enewy is depicted in greater detail, although equally one-sidedly, and his actions, where explained, are attributed to the machinations of the Devil. Although it would be fanciful to expect rounded characters in view of mediaeval conceptions, even this primitive view of human nature leaves room for observation and manoeuvre, a facility appreciated by Epifanij.

Naturally the Permians are depicted as wicked before conversion and perfect after, but the portrayal of the conversion itself is not nearly as unsophisticated as this would suggest. Epifanij describes the conversion as a gradual process; first some want to believe, but others

18. f. 684 .

19. A rare exception to this is the portrait of the cother in Nestor's Life of Foodosij of Monastery of the Caves, in Sbornik XII veka moakovskago sobora, reprinted from the edition of A. A. Saxmatov and P. A. Lavrov, 1899, (Apophoreta Slavica, I), The Hague, 1957. pp. 40-97. 
forbid them. 20 Next, a few converts suffer the jibes of their fellows, 21 then gradually, more attend the services to admire the beauty of Stefan's church and are Iinally won over. $^{22}$ so although there is no attempt to portray the progressive psychological change leading to the conversion of any one individual, the external behaviour of the Permians as a group reflects the inevitably slow inner process of conversion; a wch more credible picture than that of the instantaneous mass conversion of the aussians in Povest' vremennyx let. 23 Pam, the Permian shamall, never adopts Cliristianity. After his defeat in debate and failure to undergo the trials by fire and water that he has proposed to Stefan, he leaves 'Perm' a beaten man, promising never to return and preach the old religion. 24 The utter humiliation of the enemy is more effective and convincing than his conversion could be.

The episode with the shamen is distinguished by realistically Dotivated argument and drama. l'am first approaches the group of permian converts and tries to sway them by a variety of means; appeals to logic, llattery and bribes. 25 The arguments he puts forward are conservative patriotic requests not to forget the faith of their fathers, to listen to him, their old teacher and a l'ermian like them and to ignore stefan,

2u. f. 671 .

21. f. 671 .

22. f. $6.3 \mathrm{r}$.

23. S.a. 933. See Povest'vremennyx let, ed. V.P. Adrianova-Peretc, I, M-L., 1950, p. 81 .

2l. f. 714 .

25. f. 604. 
the creature of treacherous Moscow. 26 kvoking no positive reaction he threatens to turn his gods on Stefan, to which the Permians laughingly reply that the old gods have been utterly cast down. Pan, incensed, threatens retribution. 27 The vivid scene is interrupted by a digression, which draws parallels between the shaman and biblical opponents of righteousness and good. Further boasts lead to a confrontation between the two, and here also, Epifanij maintains his efforts to aake the shaman a convincing figure. Although the speeches of the two wen are too $10 n$, thus losing in dramatic tension, they differ both in style and content. Stefan quotes extensively from the Bible. 28 The shaman, as might be expected, does not. 29 The modern reader is unlikely to be impressed by Stefan's arguments which are all based on the authority of the Bible, but it would be wrong to see this as an artistic failing. Deductive reasoning of this kind was normal at the time, and would not have been considered illogical by Epifanij's audience, who would be unaware of the obvious objection that Paw, not being a Christian, would not be swayed by appeals to statements in the Bible. The shaman's arguments on the other hand, are both more persuasive and artistically interesting. He demands to know who sent Stefan to Perm'to insult their traditional religion, threatening to cast spells which will take the people away from stefan. 30 Stefan replies

26. r. 695 v.

27. I. 608

28. Nonovalova, 'Poxval'noje slovo', p. 109; Lixatev, Kul'tura Husi, p. 71.

29. Epifanij's language was so saturated with biblical phrases and expressions, that he was unable to be consistent in this. See pt. II, chap. $v i$, infra.

30. I. $701 \mathrm{v}$. 
that the Permian idols have been proved impotent: he has destroyed the sanctuaries without retribution. Pam defensively replies that his gods have merely chosen to be merciful to Stefan. He rurther argues that one god cannot possibly be as effective as many: the Permians have gocs in forest, field and stream, who supply food for the permians and furs prized by the rich of Moscow, Lithuania and the Horde. Noreover, the Pussians are inferior to the Purmians, cowards, who dare not fight a bear in single combat. Such arguments are so realistic that it may be surmised that they were what the shaman actually said to stefan. 31 They further reflect Epifanij's vigorous efforts to ensure his audience's conviction of stefan's sanctity.

ifter further discussion, Pam proposes a trial of faith. The two are to step through fire and descend beneath the ice of a frozen river. At the last moment the shaman backs down and thrice refuses to undergo the trials. His bluff has been called. After first asking Stefan whether he could pass unscathed through fire, to which he received a negative reply, he cunningly suggested the trials, in the expectation of Stefan's capitulation. Stefan stands firm, because for him the ordeal is a trial of the faith for which he is prepared to die. 32 His is a psychological victory: the strength of his faith enables him to defeat the shaman. The account ends with jtefan's rejection of the Permians' suggestion that Pam should be put to death; a wise decision because it does not permit him to be a martyr for the old religion.

The episode displays a number of remarkable features: the depiction of a moral victory, the use of drama and an attempt at realistic characterisation reflected in the differentiation of dialogue, realistic material

31. Kljucerskij, op. cit., p. 96.

32. 5.711. 
arguments for the Permien religion, the oradual process of conversion show by external weans and the portrayal of the shaman. A comparison of this account with those of struggles between other saints and their enemies yields nothing similar. 33 for since works like the vita Constantini or Evtinij's Life of Ilarion of Möglen contain debates with heretics rather than pagans, their authors dared not represent heretical views fairly for fear of affecting their audience. Epifanij, on the other hand, was free to employ drama, realiam and rhetoric to make Stefan's victory seem more impressive.

A sibilar subtlety may be observed in the account of the destruction of the Permian sanctuaries. In itself this episode is no more than a conventional way of showing superstitious people the superiority of one religion over another, but Stefan's refusal to touch the fine furs that adorn the sanctuaries is a subtle illustration of his unmaterialistic outlook, a moral superiority that is an important factor in the conversion of the Permians. 34

The various graphic pictures are each followed by prayers, biblical quotations and parallels stressing their spiritual significance. when Epifanij comes to the end of his account of the wission, he breaks off the narrative to insert a whole chapter, a general discourse on the value of missionary activity, expressed by strings of poetic quotations largely from the Book of Psalms. Then comes a less poetic, logically argued section explaining why it was vital that the Permians should be converted,

33. Epifanij's treatment of the debate is analysed closely in pt. II, chap. ii , pp. $68-\not$ infra.

34. ff. $689 \mathrm{v} .-690 \mathrm{v}$. See also f. 684. The juxtaposition of the materialist religion of the Permians and the spirituality of Christianity was noted by A. Krašennikov, 'Apostol'skij podvig sv. Stefana Permskogo', Kurnal moskovskoj Patriarxii, 4, M., 1949, p. 19, in an otherwise unscholarly article. 
followed by the famous comparison with the work of Greek philosophers and St. Cyril in composing alphabets. Stefan's achievement in creating alone a literary language and alphabet for the Permiana is lauded in poetic turns of language. An eulogy of his other achieveaents follow. This abstract section is extremely long; more than a quarter as long as the whole of the section about Stefan's mission, which itself is not all narrative. The parallels lift Stefan to the height of the apostles and great missionaries, and the eulogies proclaim his faith and spirituality, both essential to Epifanij's concept of the vita.

The Life of Stefan of Perm' is unusual in many ways. Charges that it is abstract and non-factual are clearly unfounded, although it is of little interest as a historical source or as biography in the nodern sense. Neither was the primary aim of the nediaeval hagiographer whose task was the portrayal of an edifying ideal. Epifanij in this respect is typical: as far as possible he adheres to the traditional schem. When he diverged, it was because of his concept of the saint and his literary portrayal: Epifanij saw Stefan as a saintly man opposing a materialistic religion with his om spiritual example, a man so far above others that this had to be expressed not only by a poetic style but also by series of difficult contrasts between his ascesis, described realistically, and his spirituality expressed in biblical parallels and sincere effusions of poetic praise. This nethod ties in with his problea of convincing Russians of the sanctity of a missionary to a little known tribe. He describes the mission so vividly that they could not but be impressed; then follow passages which lift stefan above these earthly surroundings.

The problew of conveying the saintliness of a mas as yet uncanonised is not sufficient to explain Epifanij's brilliant narrative and style. For Domentian and Evtiaij did not face Epifanij's particu-

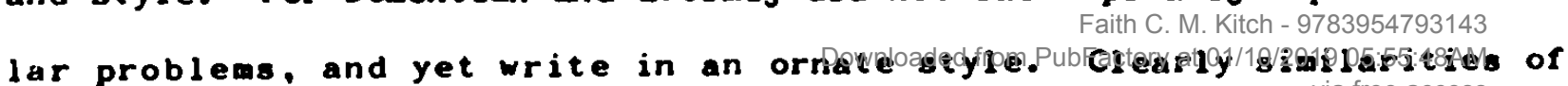


style have obscured basic differences in their appraaches to their work. Lomentian's Life of Sava and Life of Simeon, in so far as they recount the lives of the first Serbian archbishop and the first Serbian king, are obviously likely to include more historical detail than the life of Stefan of Pern', and yet, as has been observed already, Domentian makes a special effort to play dom historical and geographical information dates are avoided, place-names are few, and reconstruction of events is very difficult without a previous knowledge of the period. What facts there are, are 1988 noticeable than they might be because of the structure and style of the works. In contrast with the life of Stefan of Pers', Lomentian's vitae are almost formless. There is no abstract introduction to the Life of Sava: Domentian relates how he collected his material about halfway through the work when it occurs to him to do 80,35 and the conventional topos of self-humiliation of the author is found shortly before this. 36 Both would be expected in the introduction or conclusion.

Tone and style are affected by this. In the Life of Stefan of Perm', the emotional tone gradually rises, although there are other high points in the central section in the description of the mission, the building of a church in Perm', and particularly in the description of the creation of an alphabet and literary language. Nevertheless, the three laments at the end crown the life. In contrast, the emotional tone of Domentian's vitae is uniform, making rhytha, repetition and other poetic devices less striking than in the more varied Life of Stefan of Pern'. Each mention of the saints is accompanied by expressions of praise:

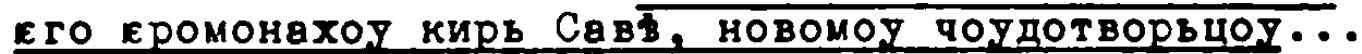

35. Laničć, op. cit., p. 132 .

36. ibid., p. 172 . 
Sometines these develop into rull-scale eulogies which together with Hiblical parallels and prayers provide more frequent interruptions to the narrative than in the Life of Stefan of Perm'; 37 thus when Sava visits the Near bast, Iong accounts of biblical history so slow the pace of the narrative that the thread is lost entirely. Schmaus observes that Uomentian is attempting in his Life of Sava to raise the whole life onto an eternal planc. He attempts to destroy the physical reality of events by playinn down concrete details and, instead of describing sava's life and then praising him in his conclusion, he makes every event the cue for parallels with biblical stories (comparisons are even drawn with Cirist's life), and every mention of his saints an excuse for panegyric. In the resulting excessively lengthy work, facts and events almost disappear beneath a torrent of words. Whereas tipifanij uses everyday details and dramatic narrative as a contrast to stefan, the saint among the earthly, Wowentian tries to wrest the whole life from its earthly associations. evtimij's Lives on the other hand may be considered models of the formal rhetorical vita. As a result, there are no clear-cut differences illustrating the author's conceptions of hagiography. These only emerge through examination of the structure of his vitae, both in comparison with each other, and with an unusual work like the life of stefan.

None is as long as Epifanij's masterpiece. 38 This quantitative difference means less space for digression, eulogy or abstract discussion,

37. ibid., pp. $192-4$.

33. Only one fifth or one sixth as long. L. A. Imitrijev observed that variations in length in Epifanij's and Evtimij's vitae were indicative of basic differences, but did not examine the reasons for this in depth. ('Veresennyje voprosy', pp. 78-9). 
which he reserves for his introduction and conclusion, only occasionally intervening:

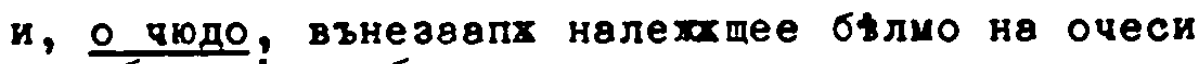

$$
\begin{aligned}
& \text { его без высти биств... (Life of Filoteja, p. 97) }
\end{aligned}
$$

It wight therefore be assumed that the central narrative section abounded in biographical data, but this is not the case: Evtimij was writing about saints long dead, and his only sources were their earlier simple biographies. His vitae would be even shorter, were it not for his involved style of pletenije sloves. However it seens that he was not distressed by the paucity of factual detail, for he did not attempt to compensate through eulogy and lyricism, and even offers less detail about events and their geographical setting than the simple originals. 40 The only exception arsong his four vitae is the Life of Petka, where information about her life was so sparse that the body of the work comprises only five pages out of a total of nineteen, the rest being introduction and concluding eulogy. In the other three vitae, the structural pattern is remarkably similar. in introduction of between thirty and seventy five lines precedes a narrative section about five times as long (although the polemic against heretics in the Life of Ilarion of Măglen means that it is much longer still). In account of posthumous miracles of about sixty lines follows, and the work closes with a eulogy and prayer of approximately sixty 1 ines.

The chart shows how ordered is the structure of bvtimij's vitae, each containing the same sections in the same order (although there is no eulogy in the Life of loan of kila). Urdered structure and the

39. The Life of Filoteja may be found in E. Kayuiniacki, merke des Patriarchen von bulgarien buthymius, Vienna, 1901, together with Evtimij's other three vitae and his four encomia. All page references are to this edition.

40. P. J. Vinekov, Stara bălgarska literatura, II, sofia, 1953, p. 63. 
THE SCHENATIC STRUCTURE OF EVTIMIJ'S VITAE

(Numbers given in the chart below represent lines in Kaluiniacki's edition, and are approximated to the nearest five lines, being intended as a general guide to the length of various sections in Evtinij'a vitae)

\begin{tabular}{|c|c|c|c|c|}
\hline litle & $\frac{\text { Life of }}{\text { Ioen }}$ & $\frac{\frac{\text { Life of }}{\text { Ilarion }}}{\text { of Maglen }}$ & $\frac{\text { Life }}{\text { of }}$ & $\frac{\text { Life }}{\text { of }}$ \\
\hline Introduction & 55 & 30 & 65 & 75 \\
\hline $\begin{array}{l}\text { Central narra- } \\
\text { tive section }\end{array}$ & 425 & $\begin{array}{c}770 \\
\text { ( largely a } \\
\text { poleaic } \\
\text { against } \\
\text { heretics) }\end{array}$ & 360 & 125 \\
\hline $\begin{array}{l}\text { Posthumous } \\
\text { miracles }\end{array}$ & 50 & 35 & 70 & 60 \\
\hline $\begin{array}{l}\text { Account of the } \\
\text { translation of } \\
\text { the saint's } \\
\text { relics }\end{array}$ & 60 & 25 & $\begin{array}{l}65 \\
\text { ( including } \\
\text { the account } \\
\text { of a aracle) }\end{array}$ & 80 \\
\hline logy & 0 & 20 & $\begin{array}{l}30 \\
\text { (no real break } \\
\text { with previous } \\
\text { and following } \\
\text { sections) }\end{array}$ & 105 \\
\hline $\begin{array}{l}\text { Prayer (usually } \\
\text { eulogistic) }\end{array}$ & 20 & 30 & 35 & 20 \\
\hline Total & 610 & 910 & 625 & 465 \\
\hline
\end{tabular}


restriction of enconium to its traditional place in the conclusion affects their tone. Dry, not very emotional, even the traditionally poetic sections of oulogy and prayer can do little to reverse this impression. Admirable as they may be as examples of vitae, showing considerable talent on the part of the author, they lack the enotional appeal of the Life of Stefan of Pera'. The one exception is the Life of Petka. It ewerges that Evtiwij only atteapted to persuade his audience ewotionally when he had little biographical detail. In other cases, he evidently intended his audience to be convinced of the sanctity of his subjects intellectually, werely through learning of their pious lives and miracles. Like Domentian, he could rely on their patriotisn to assist their credence, wich Epifanij was of course unable to do, but he differed from both of them in his simpler aim of edification through instruction rather than ewotional impact. Evtimij did compose encomia, but it is typical of a man concerned with raising standards in ecclesiastical life and literature that he keeps the two genres apart. 41 The Life of Petka alone borrows significantly from the enconiun. A man with a precise mind, Evtimij wrote strictly according to the prescriptions of rhetoric. His involved style is a means of helping the audience absorb the edifying details of the saint's biography; unlike Epifanij or Domentian, he was never so overwhelmed by feeling that conveying states of emotion rather than instructive biographical data becane his primary aim.

Through comparison of the structure of a vita with the traditional schema, it is possible to draw important literary conclusions about a hagiographer's attitude to his work. The three hagiographers writing in pletenije sloves had very different concepts of the portrayal of sanctity. Clearly, whatever Epifanij might have borrowed from the South 
Slevonic writers, his eppranch was unique. Hie treatment of the real and the wetephysical and the balance between ther was more difficult to realise than either Drtiaij's traditional nethod, or Domentian's abetract depiction of Sara and Simon. Its use of opposites led to a work of strong and varied contrasts coupled with an intensely exprese ive etyle.

41. It should be noted however, that biographical data playa a mich larger role in Bvtinij's encouia than in Kliment of Ohrid'a. He therefore is not entirely imane from the contenporary confusion between the two genres. See D. Petkanova-Toteva, 'Novi Certi na poxvalnoto alovo prez XIV-XV V.', Tărnovaka knizovne akola, 1371-1971, eds. P. Ruser, G. Dancer, E. Saratova, Sofia, 1974, pp. 91-5. 
Dialogue as a general rule is not a significant aspect of hagiooraphic style, for the creation of an idealised portrait and consequent neglect of other characters precluded the exploitation of its possibilities for characterisation. In vitae, dialogue and monologue operated within lisits imposed by the purpose of hagiography, and any be classified into four types: first, debate between saint and heretics or pagans, in which the Platonic nethod of philosophical discussion by question and answer is adapted to Christian ends. It serves to bring out the saint's erudition and virtue but reveals nothing further of his personality. The second type of dialogue appears in narrative episodes, relating the ascesis of the saint or his posthumous miracles. Here as in the chronicles, dialogue usually forwards the action, and may possess a distinct dramatic effect. The third form of dialogue is found in scenes where disciples ask the saint for spiritual guidance. An excuse for the saint to expound on some aspect of Christian teaching, and an opportunity for the hagiographer of displaying his subject's wisdon and piety, the resulting hosily is less dialogue than monologue. Finally, the vita employed

a form of internal monologue, which should be distinguished from 'le wonologue intérieure' of the modern novel which has been defined as 'the expression of the most intimate thoughts, those wich lie nearest the unconscious...! Mediaeval internal monologue, consistent with the prevailing conception of the individual, is merely a device for introducing the audience to the thoughts of the character without the author appearing to intervene. In the vita, internal monologue affords insight only into those facets of character central to the presentation of a saint.

1. Dujardin, quoted by R. Wellek and A. warren, Theory of literature, Harmondsworth, 1965, pp. 224-5. 
The dewands of the genre combined with the hagiographer's traditional humility prevented him from essaying a guess at his subject's real thoughts. But he did not shrink from attributing pious cliches to him, on the assumption that his thoughts were identical to those of other saints.

All four types of dialogue or wonologue appear in the Life of Stefan, often employed in a novel fashion. The first, the debate, is altered almost beyond recognition. In the Vita Constantini for example, Cyril debates the superiority of Christianity over Judaism with a Xazar philosopher (the Xazars professed a form of Judaism). Through a series of questions and answers, his opponent is gradually caught in a logical trap. Hut the success of this method depends on Cyril's knowledge of how his opponent will reply, and as such represents a decline of the Platonic tradition of philosophical debate. Plato's dialogues are stages in intellectual discovery. In seeking to define justice, for example, jocrates, through whom Plato speaks, feigns ignorance of the answer, thus creating a lively impression which is further assisted by the characterisation of some of Socrates' opponents. In the Vita Constantini, both sides start from a rigid position of conviction, and the debate is as a consequence only a theological jousting tournament. rurthermore, the Xazar philosopher is no wre than a wouthpiece for Judaism, vith no individual features at all.

Cyril's powers of debate were developed by his Byzantine training in rhetoric and dialectic. It is not surprising that the Slars, who did not adopt Byzantine educational traditions, failed to develop a tradition of theological debnte. Original Slavonic vitae demonstrate the further degeneration of the Platonic tradition by turning Plato's questions into rhetorical questions; the saint my appear to address questions to his 
opponent ar audience but he does not expect them to reply, and cont inues without allowing them an opportunity to do so. Evtimij's Life of Ilerion of Măglen clearly illustrates this development: llarion's discourse with heretics is entirely one sided. As in the debate in the Vita Constantini. the reaction of Ilarion's opponents is anticipated, and the continuation of his arguwent based on the saint's assumptions about his audience's views. Not merely has the Platonic tradition lost its liveliness and spontaneity, but it has even been transformed from dialogue into monologue. The only remaining link with a tradition of logical discussion is in the use of questions.

Debate in the Life of Stefan of Perm' differs from either of the two types described above. In one respect, in its rejection of logical arguwent it forsakes the platonic tradition entirely. Whereas Ilarion develops his arguments logically but does not permit an exchange of views to develop, Stefan in his debate with the Permian shaman werely asserts the superiority of Christianity, basing his arguments upon the Bible and the decisions of the great Church Councils. In another respect, bipifanij's presentation of the debate between stefan and the shaman is closer to Platonic traditions: the shaman is at least allowed to present his arguments. Since Epifanij had no fear that his Christian lassian audience would be swayed by the shaman's views, it was not essential to reply to them logically. In fact the shaman's 'arguments' are a series of poverful emotional appeals addressed directly or indirectly to the Permians. Epifanij was even able to employ rhetoric to make his speeches more persuasive and hence more of a threat to Stefan:

отечьских богов не оставливаите, в тертв и треб их не звбиваите, а старыи пошлины не покидыввите, давния вьры не пометаите, ите творипа отцы наши.

(f. $695 \vee$. 
In this way, debate in the Life of Stefen regains sose of its former live1 iness.

The secand type of dialogue comon in hagiography is a weans of forwarding action and possibly providing dranatic effect. In the central section of the Life of Stefan, this type of dialogue is frequently found, but interestingly, it is not evenly distributed. There is no dialogue at all at the beginning of the aission; anly Stefan's hoailies, which get a hostile reception are relayed in direct speech. It is as though the pagan Permians are incapable of verbal communication until they are affected by Stefan's forbearance in the face of provocation. Even so, reported speech is wuch more frequent at this stage. Direct speech becomes common only when the shamen appears among the new converts and confronts Stefan. Here it is employed to considerable effect, particularly in the exchanges between Pam and the converts. Thus the shaman, frustrated by fruitless efforts at persuasion turns to insults:

$$
\text { единаче ви, зрю, без разума есте, слаби те и }
$$
груби знло и стрвшиви и мвловьри...

(f. 696 v.)

Even Stefan who prefers the dignified argument to the crude jibe makes an emotional appeal in his first address to the Permians."

it the same time, dialogue in the Life furnishes a picture of the behaviour and attitudes of the Permians that is remarkable in a vita. Not only do they express their attitude to Moscow, but also their changing view of Stefan and hence to Christianity. The convincing presentation of the conversion of the Permians as a gradual process is assisted by a novel adaptation of dialogue: the Permians discuss anong thenselves Stefan's fortitude and benevolence and decide to accept baptisa. The process of decision is conveyed by dialogue; initially they are impressed 
but still vaverings

$$
\begin{aligned}
& \text { слишасте ли братие, словеса иукв того, ите } \\
& \text { от Руси пришедтвго? Видысте ли терпьние его, } \\
& \text { и преиалишнюо его любовь, ете к наи, како в } \\
& \text { толицых тыснотах, и не отступи отскду? А иы } \\
& \text { велико небрехение и непослушвние показвхом } \\
& \text { eบY. • } \\
& \text { ( . } 687 \text { ) }
\end{aligned}
$$

by the end they are comitted?

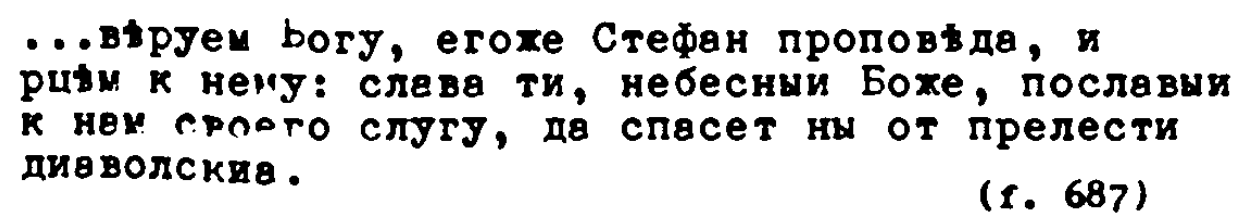

The treatment of dialogue to strengthen the plausibility of the conversion as well as heighten dramatic tension is a feature specific to the Life of steran. 3

Wre other variant on this category of dialogue is found in the central narrative section. The trials of faith undertaken by Stefan and the shaman which conclude their lengthy but inconclusive debate are excellent examples of Epifanij's dramatic technique with the shaman begging for mercy, accusing stefan of deception, while the Permians jeer at his discomfiture. This episode is structured round threefold repetition 'triads', reminiscent of the Vita constantini. 4 The shaman is thrice asked to undergo the trial of faith. Thrice he refuses. Three times they ask him why, three times he is made to confess his cowardice. "hat is remarkable here is the realistic conversational nature of question and

3. See p. 58 supra.

4. As il. duty points out in 'The gospel and psalter of Cherson: Syriac or thssian?', To honor lloman Jakobson, The Hague, 1967, pp. 116-7, triads or the organisation of episodes into groups of three, are an important principle in the structure of the Vita Constantini. Their presence in the Life of Stefan of Perm' may also be attributable to the symbolic meaning of three to the Permians, or less probably to the three-fold repetition of the tussian fairy tale. 
answer. Though a stylised structural formula, it is here presented in a lifelike fashion.

The third form of dialogue common in vitae, the request which prompts a homily is rare in the Life of Stefan of Pern'. When Epifanij does employ this comoon method of demonstrating a saint's apiritual wisdom, he places the discussion in a concrete setting and relates it to a specific problew; the Permian converts, puzzled by Stefan's total destruction of heathen sanctuaries and the valuable furs within them, vonder why he saved nothing for himself or for them. They add weight to their arguments with a biblical quotation, 'the workman is worthy of his meat'. 5 stefan watches their quotations with three of his own explaining his action. This brief homily is as much a justification of Stefan's action and a dewonstration of his moral superiority as a display of his risdom. It is more lively than the conventional request for guidance in vitae.

Epifanij Premudryj's treatment of the last category of dialogue, the internal monologue, in the Life of Stefan of Perv' reflects an exagerated sense of his own unworthiness; Stefan's thoughts are rarely even recorded in words that can be described as Epifanij's om, even if topoi. Instead, Epifanij threads together quotations from the most authoritative of Books, the Bible, and presents these as his subject's meditations. jo Stefan surrounded by hostile Permians reflects upon the inevitable delivery of the just from the wicked in a chain of quotations from the Psalter. 6 Apart from further illustrating Epifanij's humility, this wethod serves his general concept of sanctity by exalting Stefan above

5. Matt. 10, $x_{0}$

6. .672 v. 
other men whose thoughts are not naturally expressed through the nedium of quotations from the Scriptures.? Internal wonologue is also expressed in the form of prayers, which in the life of Stefan of Perw' are not remarkable except for their frequent inclusion of biblical quotations. 8 Epifanij's interesting use of dialogue is not paralleled in Evtieij's vitae, where except for the polenic in the Life of Ilarion of Molen, dialogue is largely found in narrative episodes. There is little that distinguishes Evtimij's use of it in these episodes from that of many other rhetorical vitae. Thus the conversation between Filoteja and her husband Konstantin in which they declare their determination to follow the path of God, enlivens the account of an episode, without either revealing wch of their characters or adding a strong dramatic note." Interior conologue is neither frequent nor developed. 10 In Damentian's Life of Sava dialogue is so rare that it gives a false impression of liveliness. Brief questions elicit long diffuse answers, when a single word would suffice. A request for factual information becoes a cue for paneoyric as when bandits ask a herwit whether Sava is in truth his disciple, to which he replies prailing God and Sava at considerable length. 11 Thus a siaple question which wight have served to forward the action is

7. The three final lacents should not be regarded as examples of aediaeval internal monologues as they are not employed to enrich and explain the narrative. For a consideration of the lament: in the Life of Stefan of Pera', see Konovalova, 'Poxral'noje 810 o'.

8. On the use of biblical quotations in the life, see pt. II, chap. vi, infra.

9. Life of Filoteja, pp. 82-3.

10. See for example, the Life of Petka, p. 64.

11. Life of Sava, p. 136 . 
actually ade a pretext for departure from narrative. 12 The effect of this is to destroy the dymanisn of the narrative, consistent with Dowentian's literary aims of abstracting the lives of Sava and Simeon from their concrete setting. Debate is one-sided and internal conologue uncomon; the wst striking example, in which Simeon lawents his son's flight into a mastery, is highly conventional, linked both to the haglographical tradition of the parent who opposes his child's desire to enter a monastery and to the Christian and pagan lament. 13

Thus Epifanij, alone of the three hagiographers under scrutiny, puts dialogue to telling use. Taking traditional forms of dialogue, the debate, the request for guidance, and dialogue as an integral part of narrative, he enhance their dramatic qualities to assist his overall conception of the mission as Stefan's supreme test and achievement. Neither Evtimij nor Dowentian view dialogue as a fruitful means of assisting their portrayal of sanctity. Epifanij's predecessors should be sought rather in Kievan hagiography, in the lively episodes desciribing Feodosij's storay relationship with his mother, or in works conforming less closely to the canons of hagiographic literature such as the Passion and Encomiun to Boris and Gleb.

\section{Whetorical guestions}

Dialogue in vitae, it wight be noted, is usually based on a series of questions and answers, though the question may be unspoken. The hagiographer had at his disposal another related stylistic device which also

12. Oddly enough, Domentian does not consistently take advantage of narrative situations were his subject's piety and wisdom might be displayed to effect. Sava is asked in Jerusalem about his travels, a situation that Dowentian aight easily have tumed to his advantage but he merely remarks that Sava replied to all the questions he was asked (p. 303 ).

13. p. 27, c.f. Nestor's Life of Feodosij. The obvious links with the Lament of the Permian people should not be taken as an example of the influence of Domentian on Epifanij; the textual parallels are insufficiently close. 
served to involve the reader more fully. This was the rhetorical question which like wany other features of Christian rhetoric possessed a dual ancestry, classical and biblical. Phetorical questions are employed extensively in Hebrew poetry minly as cries of despair or sorrow, rather than appeals to the intellect. Since the Old Testasent tradition so closely affected Christian poetry and poetic prose, it is legitinate to assuse that rhetorical questions would be a favourite weapon in the stylistic armoury of Epifanij, Evtioij and Dowentian. But it is again clear that, in spite of their wtual liking for these as for other devices, differences are more significant than sibilarities. As before they are dependent upon the overall conception each hagiographer had of his work. If rhetorical questions involve the audience wore effectively in the work, then their absence would suggest that the author intended to maintain the distance between himself and his audience. So Domentian's Life of Sava which lifts the events of Sava's life beyond concrete reality makes sparing use of rhetorical questions, ${ }^{14}$ though the Life of Simeon, which applies the method of abstraction somewhat less thoroughly, employs a higher number. In some cases these are linked in groups of three, further sharpening the emotional effect. 15 Evtimij employs his habitual restraint in embellishing his vitae with rhetorical questions. 16 Found singly, they are part and parcel of that admirable formal rhetoric with which he glorifies his four bulgarian saints. In the Life of Stefan of Pere', on the other hand, there are no less than 115 rhetorical questions, of

14. A were twenty in a work of amazing length. Furtherwore, half of these are biblical quotations.

15. For example pp. 27, 31.

16. 28 in al1. 
which no more than half a dozen are biblical quotations. When one considers that Kiprian in the Life of Peter, Paromij in the Life of Kirill of Belozerak and Nestor in the Life of Foodosij do not enploy a single rhetorical question, this figure sees truly extraordinary. 17

Most of the rhetorical questions in the Life (eighty out of 115) are found in the three final laments, were they are an important stylistic device. They do not invite the audience to follow the narrative, but rather to share the exotions of the Permians, the Permian Church and the author lamenting the death of the bishop wissionary. Rhetorical questions express various deep feelings; grief, despair, helplessness, inadequacy, reprach, bereavement, wonder. 18 They are distinctly reainiscent of the type of rhetorical question or exclamation found in the Psalter, and often quoted by Epifanij. 19 But were rhetorical questions in the Paslter are found singly or in pairs, 20 in the lawents they form intricate lyrical cha ins:

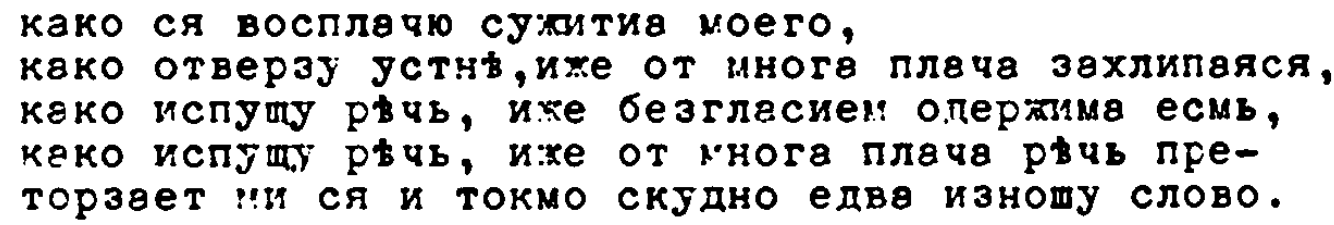
(f. 758 v.)

This example demonstrates clearly how these are combined with various forms of rhythaic devices. 21 Or they are repeated at intervals as a refrain, as when Epifanij labours to do justice to Stefan's great virtues by coaparing

17. Nestor does however employ them to great effect in his Lection on Boris and Gleb.

18. If. $754,749 v \cdot, 765,753 v \cdot, 757,773$ v. respectively.

19. As 1. 673, where Epifanij quotes frov Ps. 3, i, 'Lord, how they are incroased that trouble we' (given as an exclanation not a rhetorical question in the Authorized Version).

20. For example, Ps. 22, i.

21. Tlese are analysed more fully in pt. III, chaps. ii and $v$ infra. 
hil with the ranks of the blesed and showing hil worthy of each title, - formia taken ultinately fron the acathistus. Ho begins with a question that would seer to contain all the smonge of 'call' and 'praise',

но что тя нареку, о епископе, или что тя именую, тпи чим тя приаову, и како тя просвзщво,

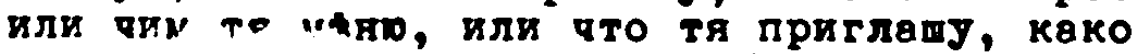
похвөлш, како почту, квко ублаку, како разлоку и као хвалу ти сзплету?

$$
\text { (x. } 765 \text { r.) }
$$

This staggering display of linguletic virtuosity is aucceeded by an -laborate parallel with the rarious ranks of the blessed, linked one to another by the use of the implified question, 'cto t'ja narela'. 22

This type of poetic treatment of the rhetorical question is in a ach impler form a common feature of the concluding culogy in formal vitae. Thus the question: 'who way praise hil worthily' or 'how may I praise him as he deserves' is found in the Life of Foodoalj, the Lection on Boris and Glob, the Life of Sinoon, no less than nine times in Drtinif's vitae as well as in the Life of Stefan of Pere'. 23 The question 'who would not marvel at the saint' is found in the Life of Petka, Nestor's Lection, in a rariant form in the Passion and Dncomium to Boris and Glab and in the Life of Stefan of Pern'. 24 But where other hagiographere atring two or three such questions together embelliahing old Testament poetic tradition but little, Epifanij creates elaborate coplexes of questions whose enotional llpact lo etrengthened by a galaxy of rhythmic effects.

22. $\quad 766$.

23. Life of Foodosij,p. 89, Lection, p. 25 , Life of simeon, p. $31 ;$ Life of Ion of Rila, p. 9 (twice); life of Potka, pp. 60 (twice), 63 (twice) i life of Filoteja, pp. $72,75,78$, Life of stefan, 1.751. Full bibllographical references to these texts are given in the appendix, p. 290.

24. Life of Petka, p. 71; Loction, p. 25; Pession and Dncomium, p. 31; Life of Stefan, 1.773 . 
Whetorical questions are also employed in the central part of the Life, when Epifanij wishes to appeal to his audience, either as orotive refrains 25 or exphatic repetition. Thus Epifanij eaphasises Stefan's invincibility when, aided by God be destroys the Permian idols: qто бо могут согворита бнса, или что могут вредити

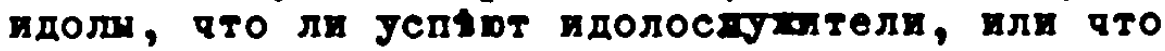
иогут дынтвовати кЈдесншка, кјмпрнику $n$

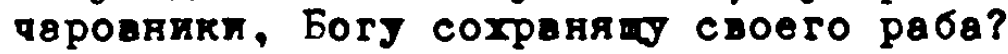

Epifanij also addresses those who evidently had doubts about the value of Stefan's missionary work. Ho imagines their questions: 'why were Books translated into Permian, or what was the Permian alphabet created for ? $^{\prime}$ And then proceeds to offer his justification of Stefan's work through the citation of relevant biblical passages. Though this my have helped quell the objections of some contemporaries, to a modern reader it naturally casts doubt on Stefan's claims to canonisation rather than confirming thea. It is indicative of Epifanij's forgetfulness of the wider timeless aims of the vita. His method of involving his audience closely in the Life is only valid when he has the whole audience in mind. Thus epifanij is the only writer of pletenije sloves who significantly extended the stylistic use of rhetorical questions. Though Evtimij and Domentian in the Life of simeon (if not in the Life of Sava) made slightly wore use of them than hagiographers before them, they do not comprise a major stylistic device in their vitae. The slight increase in incidence may be attributed to the incursion of panegyric into the formal vita at this period. but in Epifanij's case, only his concept of the vita may adequately explain his predilection for rhetorical questions.

25. S. 663 . 
The reader of the Life of Stefan of Perm' cannot but be aware of Epifanij's views and feelings. In the body of the work, his attitudes are presented indirectly through his method of presenting the various episodes, but in the exordium and laments he makes an open appearance. This is in conformity with hagiographical etiquette, which permitted those personal statements consistent with authorial duty; either recognition of the writer's moral inferiority in relation to his subject, or his inability to celebrate the memory of his saint in fitting literary style. These forms of the traditional humility topos were previously regarded as a feature peculiar to ltussian hagiography of the period of the second south Slavonic Influence, ${ }^{1}$ Nekrasov even going so far as to suggest that such sentiments in Paxomij's vitae indicated an acknowledgement of the low standards existing in Kussian literature: ${ }^{2}$ Uthers realised that the humility topos was not restricted to tussian hagiography, but only either traced it back to Kievan vitae, ${ }^{3}$ or declared it a feature specific to pletenije sloves." Though recent investigators have understood

1. KljuČevskij, op. cit., p. 375; Jaxontov, op. cit., p. 16; A. hadlubovskij, OCerki po istorii drevne-russkoj literatury zitij svjatyx, Warsaw, 1902, p. 173.

2. Nekrasov, op. cit., p. 85.

3. S. Bugoslavskij, 'Literaturnaja tradicija $v$ severnovostočnoj russkoj agiografii', jtat'i po slavjanskoj filologii i russkoj slovesnost i (Sbornik statojv Cest' Alekseja Ivanovila Sobolevskogo), L., 1928, p. 335, notes the presence of the humility topos in the Lives of Avraamij of jmolensk, jergij of ladone 2 , Nifont, Varlaam Xutynskij, Kirill of Belozersk, iritirim of Perm', Stefan of Perm' and many others and postulates a source in Nestor's vitae.

4. B. Jablonskij, Paxomij Serb i ego agiografičeskije pisanija, jt. P., 1903, p. 232, points out that the humility topos is present in the vitae of Domentian and Daniil as well as of laxomij; Umitrijev, 'Neresennyje voprosy', p. 75, suggests that the humility topos was part of the obligatory exordium in vitae of the period of the second Slavonic Influence. 
that this is a device far older, wot ignored entirely its history. 5

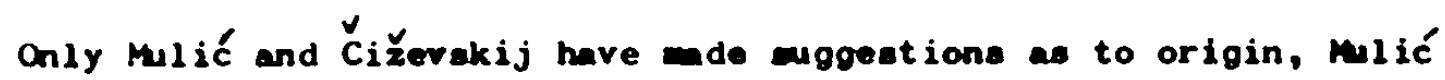
inaccurately ettributing it to the Palm, ${ }^{\prime} X_{i} y_{\text {erakij }}$ corroctly pinpointing ita links with the rhetoric of Antiquity. 7

The orator of Greece or Row, in ettempting to incline his listeners favourably to his arguments, had recourae to a sies of statements designed to attract a syapathetic hearing. Of these, the nost important was a posture of modesty, recomended by Cicero and guintilian among others. 8 It might be reinforced by protestations of inadequacy (whether through lack of preparation or absence of oratorical skill). Such modesty formulae, as Curtius points out, 'achieved an inmense diffusion, first in pagan and Christian late Antiquity and then in the Latin and vernacular literature of the Middle Ages'.9 They are equally common in byzantine literature, both secular and ecclesiastical. In being adapted to Christian literature, certain shifts in emphasis occurred; the writer referred more often to his sinfulness before God than to his general feebleness, a natural development in the light of

5. U. S. Lixačev, 'Izobraženije ljudej'; O. F. honovalova, 'k voprosu o literaturnoj posicii pisatel ja konca, XV v.', TUDL, XIV, M-L., 1958, pp. 205-11; Nianson, op. cit., pp. 101-5, mentions the humility topos in his excellent discussion of the conventional structure of the exordium in Rassian hagiography of the XIV-XVth centuries, but does not treat it in any detail.

6. Mlić, 'Srpsko pletenije sloves', pp. 123-4, attributes the compulsory topos to Ps. 115, iii.

7. Č́iŽerskij, 'Zur Stilistik'.

8. Curtius, op. cit., p. 83.

9. loc. cit.. For a fuller discussion of the history of the humility topos in the west see Curtius, op. cit., pp. 82-5, 159-62. 
Christian ethics. The authority for this change was the Bible, where attitudes of self-abasement before God are commonplace in the Psalms and other Old Testament books. 10

Since the structure of the formal rhetorical vita ras based on the Classical encomium, it is not surprising that modesty formlae passed from one genre to the other, Loparev noting their presence in the exordium of ninth century Greek Lives. 11 If protestations of humility are commonplace in vitae, it wust be considered whether Epifanij's assertions exceed conventional demands and if they do, then it remains to establish whether he is representative of a tendency in all hagiography written in pletenije sloves.

Such problems are resolved most simply through comparison of the use of the mumility topos in vitae of different provenance. For as the genre of vitae evolved, so too the various expressions of humility multiplied. By the thirteenth-fourteenth centuries they included the follow ing:

1. The author asserts his moral inferiority before cod; he is sinful and unworthy, and may contrast himself with his virtuous subject. 2. He laments the impossibility for a mere mortal of recording things sacred and has put dow only a little of what should have been said (the pauca e mitis commonplace mentioned by curtius). 12

3. He blames his om ignorance or lack of education, or:

4. Curses his lack of literary talent.

10. Curtius, op. cit., p. 84, cites I Samuel $24, x v$ and $26 x x$, and the Wisdon of Solomon, ix.

11. 'Vizantijskije ̌̌itija', pp. 15-36.

12. op. cit., p. 160. Both the second and the fifth categories form part of the inexpressibility topos, which may be included under the general umbrella of modesty formulae. 
He way then enlarge on this theme by declarings

5. He cannot find words sufficient to his task, and any state that

his tongue needs loosening.

He may then attenpt to seek comfort in the following statements of justification :

6. He has put pen to paper only because begged to do so. 13

7. He will put his trust in God (or the Viroin Mary, the Trinity or the saint) to help him achieve his declared aim.

8. The moral value of vitae demands that they be composed, albeit by the unworthy author.

9. So noble is this task that no man could succeed anyhow.

The author has done his best.

10. Furtherwore what he says is true, and as proof he cites the sources of his material.

11. In view of all this, he begs his audience for a tolerant reception of his work.

Naturally not all these commonplaces were to be found in all formal rhetorical vitae. Some were evidently considered more important than others; thus the appeal to God for spiritual assistance or placing of trust in Hie or his saints was almost obligatory, wore so even than the basic assertion of sinfulness and unworthiness. References to his lack of literary talent (numbers four and five in the list above) are less common than assertions of ignorance and appeals to the hagiographer's duty. The pauca e ultis comonplace also occurs frequently. Apart frow a certain freedow which lay in the seloction of which formulae to eaploy in his work, the hagiographer wight also eaphasize one or other of them, either by elaboration or by repetition. For as

13. See Curtius, op. cit., p. 83. 
the conclusion of formal vitae gradually became longer and wore complex, so wany of these modesty formlae were transferred here from the exordiun, though rephrasing was sometimes necessary. Thus in the exordium the writer sought divine aid; in the conclusion he thanked God for His assistance. The extension of the humility topos to the conclusion perwitted further emphasis or developeent if the magiographer saw fit, and widened the bounds of convention within which he operated.

Before extending discussion of the humility topos to examination of specific works, a few minor points should be raised. Some formlae do not reveal modesty without others to support them; thus Paxomij in the Life of Moisej of Novgorod justifies his act of witing by arguing that saints serve as an excellent moral example, and it is incumbent on those with literary abilities to record their deeds for posterity. 14 Though a statement of justification, this hardly reflects a sense of personal unworthiness. Alternately, the author's expression of sinfulness way be couched in the first person plural, thereby placing him on a level with men in general, and indicating no special sense of unworthiness (statements of this kind are commonplace in prayers). Or again, if he were re-writing an earlier simple account of his subject's life, he wight refer to the topos which declared that only the formal rhetorical vita is a fitting tribute to the saint. Ihus evtimij in the Life of Ioan of Rila say :

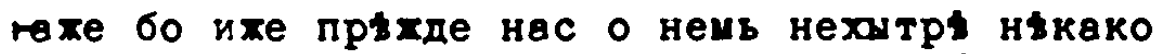

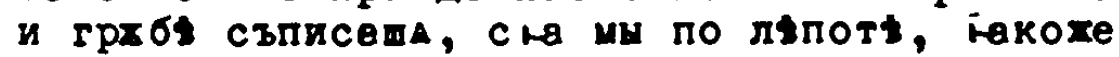
ключимо есть, оусръдно съповьдети потъдехои сА. Such a view is not, however, inconsistent with attitudes of moral ( $p .7$ ) unworthiness, and illustrates the relative flexibility of the humility

14. In Pachomij Logofet, werke in Auswahl, reprinted from the edition of V. Jablonskij with an introduction by D. Tschizewskij, (Slavische Propyläen, I), Minich, 1963, p. Ixxxiii. 
topos. It is only where a witer combines directly contradictory statements of confidence and self-abasement that he may be suspected of roodenly applying convention without regard to meaning.

Most hagiographers applied the humility topos with sensitivity, as analysis of vitae of various periods and places revealed. The following Lives were subjected to close scrutiny: Athanasius' Life of Antony, Sophronius' Life of Mary the Egyptian and the anonymous Life of Athanasia served as examples of Greek vitae. Early Slavonic vitae were represented by the Vita Constantini, Kievan by Nestor's Life of Feodosij and the Passion and Encomium to Boris and Gleb, Serbian by Domentian's Lives of

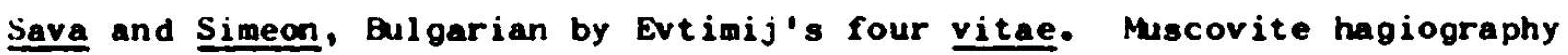
other than the Life of Stefan was represented by Kiprian's Life of Peter. Paxomij's Lives of Kirill of Belozersk, Nikon of Kadonez and Moisej, archbishop of Novgorod as well as two different redactions of Epifanij's/Paxomij's Life of sergij of hadonez. ${ }^{15}$ Pinally Epifanij's Encomiun to sergij of Radonež was included for the extra light it could cast on his treatment of this topos. 16

The results of the analysis are recorded on the chart on page 90. Since the sub-division of the humility topos is artificial, it is often difficult to separate the various formulae neatly one from the other, or in a long complex passage to decide precisely how many times a particular theme is repeated. As a result the figures given can only be a rough guide to frequency. Nonetheless, they may still act as a convenient measuring stick.

15. Redaction $G$ in Jablonskij's classification, termed Paxomijis first redaction by Tixonravov, and redaction $E$ as found in the VCM under Sept. 25.

16. References to printed editions of these works are given in the appendix of primary sources in the bibliography. 


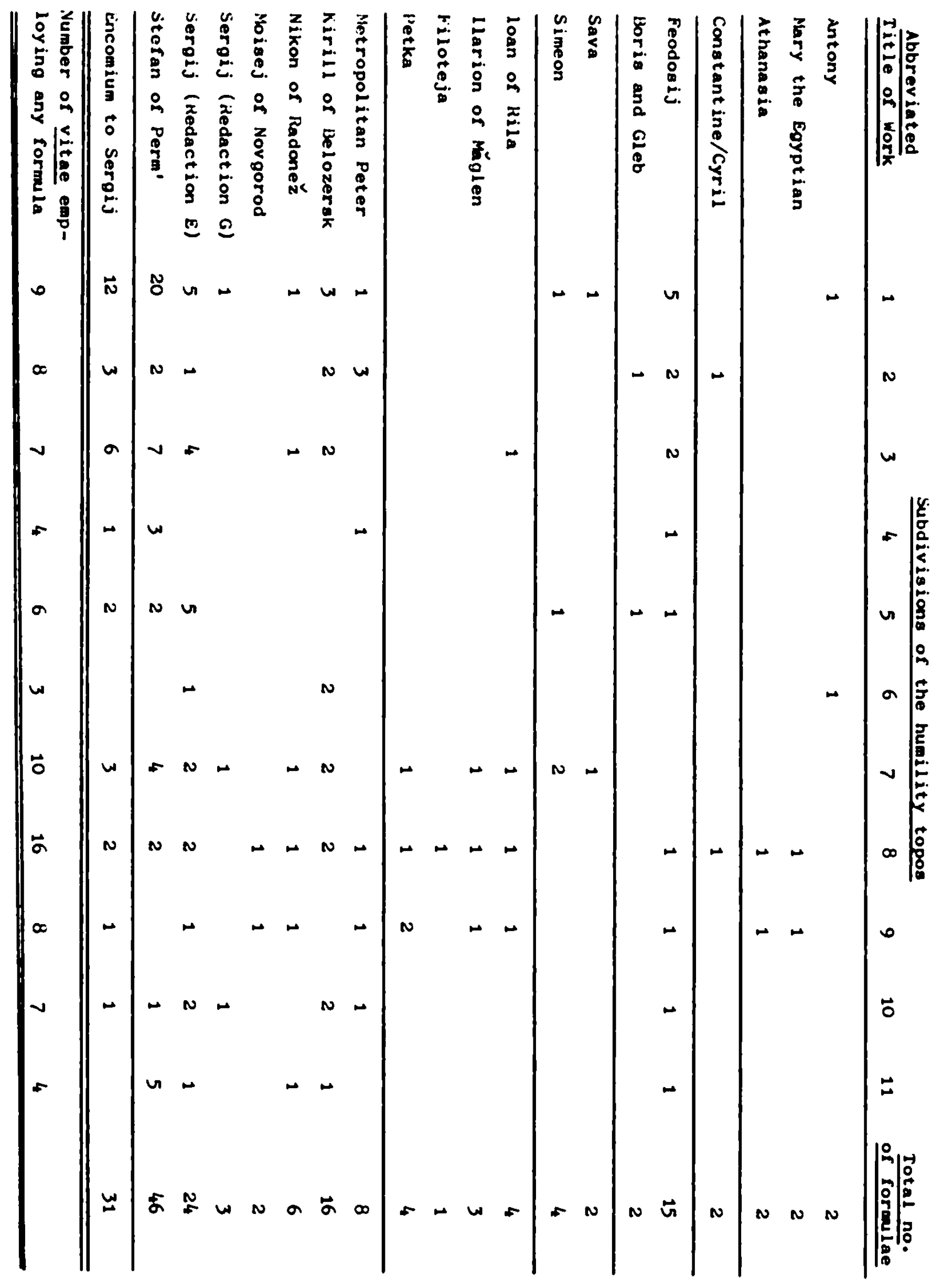


The three early Greek vitae of Antony, Mary the Egyptian and Athanasia show that in pre-Metaphrastean hagiography expressions of humility were employed with discretion, and might be omitted entirely, even from formal rhetorical vitae. Thus Sophronius in his exordium declares the value of lauding saints, and fears that these wondrous events might fade from memory if not recorded. Though he protests the truth of what he says, and in the conclusion declares he has done his best, he nowhere calls himself sinful. The Life of thanasia expresses almost identical sentiments. In the Life of Antony, on the other hand, Athanasius does refer to himself as sinful, though he does not dwell upon his unworthiness, merely going on to say that he writes only because begged to do so. 17 It is noticeable that the wording of this motif possesses a freshness and spontaneity often lacking in later vitae which were bound to conventional phraseology. Sincerity could then be expressed through elaboration and repetition rather than free wording.

is time went by the humility topos became increasingly stereotyped in form, a process hastened by Netaphrastes, who rewrote numerous vitae according to a strict schema which incorporated conventional expressions of humility. After the ninth century Greek Lives normally included some of these motifs. ${ }^{18}$ Early Slavonic vitae conformed closely to Greek practice, employing these formulae in moderation, as may be seen in the Vita Constantini, where the author refers both to the value of hagiography and to the impossibility of an adequate record. Nowhere does he express a sense of unworthiness or inferiority, though he mentions the woral

17. p. 116 .

13. Thus Guilland, op. cit., p. 174, notes that Nicephoras in his Life of intony cauleas laments his inability to write and explains how he has overcome this. 
weakness of the Slavs (our people) before their conversion by the saintly Cyril. Since other early Slavonic vitae differ little in their use of the humility topos, any developwent of these motifs in later vitae wist therefore be an independent phenomenon. However the assumption that the exaggeration of the humility topos is a feature specific to the hagiography of the period of the second South Slavonic Influence is not founded in fact, as a glance at the chart on page 90 will show. Dowentian employs it no more than Athanasius or Sophronius. In the Life of Sava, he refers to himself in the autograph appended to the work, where after applying the conventional epithet 'sinful' to himself, he goes on to explain how he was inspired to write:

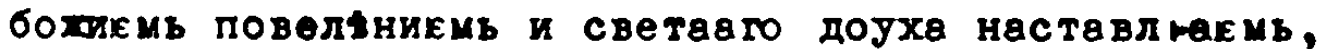

$$
\begin{aligned}
& \text { и молитвол прыосвыттенавго кирь Сави окрьмднакив, } \\
& \text { и тымь прописано бысть вь самои Свзтеи Горы... } \\
& \text { (p. 345) }
\end{aligned}
$$

Together with precise dating, this information assumes the appearance of a factual note about the author of a modern biography. Even the epithet 'sinful' carries no weight of conviction.' 19

The Life of Simeon adheres more strictly to traditional models, since it opens with a brief exordium in which Uomentian regrets that he does not know how to begin, and begs for God's grace and the gift of tongues. The conventional epithet 'sinful' of the Life of Sava is here replaced by a similar phrase nekljućimyj rab'. 20 the work agais concludes with an autograph in which Uomentian declares himself the last of Sava's disciples and asserts that he could not have written without divine

19. Domentian also mentions himself on p. 172, but without referring to his humility.

20. p. 1. The phrase is taken from Matt. $20 x, 30$. 
aid. 21 but this time the adjective 'sinful' is onitted; as though the one wention in the opening lines of the Life satisfied propriety.

Though the discovery that the humility topos plays a miniml role in Dowentian's ornate vitae is a blow to the view that modesty formulae undergo major development in Lives composed in pletenije sloves, it does confirm Domentian's approach to hagiography. The abstraction of Sava and Simeon's life from its earthly associations and elevation onto a spiritual plane weant that traditional contrasts between saint and other men, or subject and author were played down. 22 The humility topos not only accentuates the contrast between saint and others, but also introduces the personality of the author and his relation to the subject of his work, albeit in stereotyped form. Such a contrast would destroy the overall tone of the vitae. Hence Domentian either paid lip service to modesty formulae in the opening lines of the Life of Simeon, or incorporated them into a factual autograph appended to each of his vitae. Nor is the humility topos prominent in Evtimij's formal rhetorical vitae. Hdhering strictly to the conventional scheme, Evtimij excludes the humility topos from his conclusions. The one motif to appear in the opening lines of all four vitae is an assertion of the moral inspiration afforded by saints' lives. 23 This is expanded in each case to form the whole of the exordium, and in the Life of Filoteja is the only facet of the humility topos in the whole work. In the other three, Evtimij turns to God for assistance in fulfilling this noble task as best he can. 24

21. p. 117 .

22. This idea is elaborated in pt. II, chap. iv infra.

23. Life of Ioan, pp. 5-6; Life of Ilarion, pp. $27-8$; Life of Petka, pp. 59-62; Life of Filoteja, pp. 78-9.

24. Life of laan, p. 6; Life of llarion, p. 28; Life of Petka, pp. 60-1. 
In the Life of Ilarion he declares that if the work is not of a high enough standard, it is nonetheless the best he could do, and a few Ines later hopes that Ilarion will forgive him his failings. 25 The sentiments in the Life of Petka are very similar; again he states that even if the work is not up to standard, it is nevertheless his duty to write, and again declares the task impossible. 26 But there is a difference here. For the tone of lyricism which pervades the Life of Petka affects the humility topos. The exordium as a whole is more personal than in the other Lives, and individual motifs are more developed or forceful. There is both a clear assertion of inadequacy and a brief poetic lament on the hopelessness of finding anyone equipped for the task of writing:

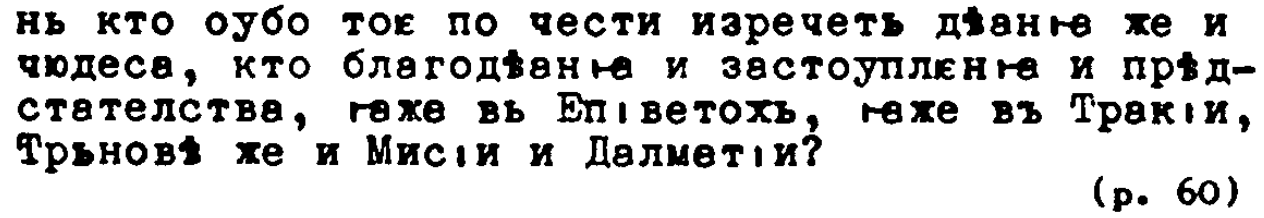

This possesses a ring of sincerity consistent with the overall tone of eulogistic veneration. But it is not possible to claim that it is representative of Evtimij's views, for in the Life of loan, though he requests God's grace that he might not 'sin through ignorance', 27 he also declares with confidence, a mere dozen lines later, that his new work is a suitably literary replacement for acrude earlier version. 28 Thus though Evtimij is aware of his human fallibility and need for divine assistance, the high value he places on the correct style for vitae precludes strong belief in his own lack of talent or a spiritual inferiority which would prevent him from writing. His protestations of humility are little wore pronounced than in many other vitae. Only in the Life of Petka does he

$$
\begin{aligned}
& 25 . \text { p. } 28 . \\
& 26 . \text { p. } 60 . \\
& 27 . \quad \text { p. } 6 . \\
& 28 . \quad \text { p. } 7 .
\end{aligned}
$$


seek to emphasize the gap between the saint and others by lyrical praise of Petka and abasement of himelf, but this one example remains the exception not the rule.

Evtimij's Lives contain a stronger personal element than is usual in earlier hagiography, 29 and this, rather than exaggerated protestations of inadequacy may reasonably be termed a feature of his work. The same personal element pervades Kiprian's Life of Metropolitan Peter to the extent that the whole biography becomes an apologia pro vita sua. Like his relative and mentor Evtimij, Kiprian opens his work with discussion of saints' lives as edifying examples, mentioning his sources and his own position as Peter's successor. 30 But unlike Evtimij, Kiprian emphasizes the humility topos by introducing it into his conclusion as well. 31 He declares his ignorance and frailty and regrets that the task is too much for him. 32 His self-abasement should however, be viewed as an attempt to ward off criticism from contemporaries disapproving of the adaptation of the life of the much-revered Peter to Kiprian's personal ends. The assertions of ignorance and inadequacy, feigned though they certainly are, may have helped the work to be accepted. In any case, hiprian's treatment of the humility topos never reaches exaggerated proportions, and can hardly have influenced Epifanij.

For in the Life of stefan the development of the humility topos reaches new and amazing proportions. Nearly all the accepted cliches are included,

29. A strong personal note is common only when the hagiographer and his subject were acquainted.

30. p. 163.

31. p. 175 .

32. Vot only on p. 175, but also in the exordium pp. 162-3. 
one of the caissions being the statement that the author was persuaded by others to wite. This was left out presumably because it would not have been true. Stefan was not highly regarded by his contemporaries, who were therefore unlikely to denand a record of his life. The work is an independent attempt by an ardent admirer to persuade others of his sanctity. The other wotif coitted from the life is, like the first, a form of self-encouragement; the adbission that hagiographical writing is an inpossible task for mortal man. So intense is Epifanij's conviction of his om inadequacy that he does not pernit himself even a shred of confort. Over and over again he laments his sinfulness, a deep noral inferiority that extend automatically to anything he does including writing. A laroe mjority of notifs express his sense of unworthiness both as wn and artist and his desperate fear that his work will not be accepted by his readers. Epifanij is not just sinful in his own eyes but nogogresnyj. 33 And when he cannot find a superlative, he elaborates on the theae:

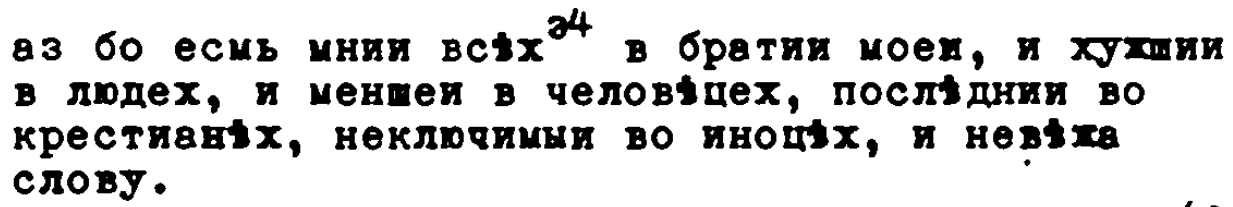

(f. 775$)$

Epifanij here amplified a simpler statement in Nestor's Life of Feodosij:

a) грьшвния Нестор, мния вьсых в манастури.(p. 96)

References to Epifanij's worthlessness slip into passages requesting

a tolerant audience, divine intercession or any other facet of the humil-

ity topos. He is haunted by an aleost orerwheleing sense of inferiority, which drives hin not only to say:

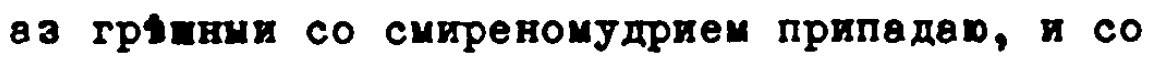

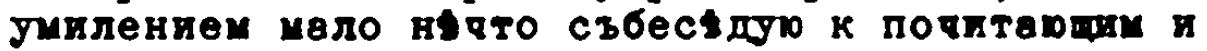
К стиваним купно те и молитвуя и простин прося:

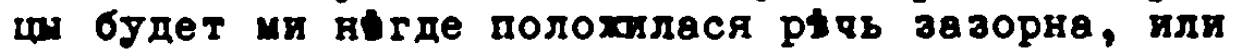

33. 5.770 v.

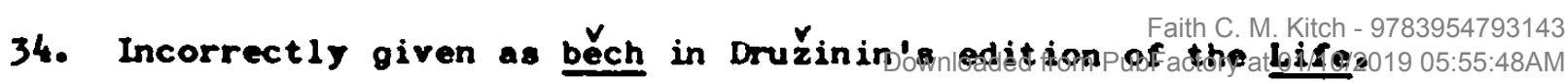


нејстроена, или недхм иена, молх ви о сем, не зазрите ми грубости, и не будите ми зазирвтеди: не бо от иудрости но от грјбости, якохе и вмше реqеся јбндихся,

(f. 653 v.)

but even to hope that his work will be revised by a core skilful and virtuous writer (an ironical touch since one of his Lives was indeed revised later, though not by a better writer):

но вше ие гораздо наппсвня бишв ныкая, но обате воамохно есть нькоеиу добриипему и иудрыппаму о Господ, построити сив и побр починити я, нејдобреняв Јдобрити, и нејстроеква построити, и неухы щреная ухитритв, и несверпенвя накончети. (f. 776 )

This spontaneous expression of feeling is unparalleled elsewhere.

Hother original touch is the comparison between Stefan, the man of many virtues and Epifanij who possesses only literary talents:

бесплоднев, Јвии чнь, яввхся смоковницв, листвие токмо едино иньо, листи книтное токмо обрапво, и листием книхным писвним токмо хввлюся, в плода добродытели не имым.

(f. 775 v.)

The denigration of literary abilities is a feature unique to the life of stefan. Epifanij is so obsessed by his sins that he must see even his writing ability as a failing.

In the opening pages, Epifanij, cast down by the magnitude of his self-appointed task, wonders how an inept ignorams like himself can compose a fitting tribute to stefan. He has only to consider hil rising head and shoulders above other wen to realise his om abject baseness. This is one of the contrasts on which the Life is founded. Just as the body of the work is a finely balanced mixture of dramatic narrative and meditation, eulogy or prayer, so the Nuthor's Lament is a heightened contrast between subject and writer. And woven into both exordium and conclusion is another form of exaggerated traditional antithesis, the plea for a tolerant reception of the work, by means of which Epifanij 
sets other men far above himself. This is a rare motif in other vitae and never elaborated as in the Life of Stefan. Its function is firstly traditional; to put his readers in a receptive frame of mind and secondly, by making them aware of the moral gap between themselves and the miserable Epifanij to perceive a similar gap between themselves and the saintly stefan. 35

Far more than other hagiographers, Epifanij infuses his work with his own feelings. He does not furnish information about himself like Nestor in the Life of Feodosij, Kiprian in his Life of Peter or Domentian in his autographs, but replaces this with a sincere and spontaneous joy and veneration. Though transported by his feelings, Epifanij was nonetheless capable of binding them into a cohesive approach to hagiography. That the intensification of the humility topos is a feature specific to Epifanij Premudryj may be confirmed by a comparison with Paxomij's vitae. Paxomij was a popular itinerant hagiographer, whose numerous vitae and encomia were subtly tailored to suit the tastes of those who ordered them. Thus the Life of Moisej of Novgorod, though written in formal rhetorical style, is simpler and less encomiastic tban for example, the Life of Kirill of belozersk. This is probably also due to the century that had passed from Nioisej's death to the date of composition, as opposed to the thirty five years separating Kirill's death and Paxomij's vita. The personal appearance of the author in the Life of Moisej is minimised; the work has no concluding eulogy or prayer and the brief exordium asserts briefly the value of hagiography before

35. The groundwork for this analysis of Epifanij's treatuent of the humility topos was done by Konovalova in ' $k$ voprosu', but her work is unfortunately marred by a number of misconceptions, mainly resulting from a slight acquaintance with hagiographical topoi. 
declaring confidently that it is incumbent an those capable of creating a fitting tribute to latterday saints to undertake the task. 36 Far from a position of humility, this betrays a fire belief in his ow abilities, an opinion no doubt shared by his contemporaries.

In the Life of Nikon and the Life of Kirill, Paromij's assertions of confidence in his literary abilities are aitigated by a recogition of his sinfulness. Nonetheless in one of the two, the Life of Nikon, the chief impression is not one of self-effacement, for Paxomij not merely states that he has written izrjadnoje ego żitije, 37 but transfers the conventional assertion of infulness and ignorance to the first person plural, thereby placing himself on the same level as others. The sole work in wich the humility topos is at all prominent is the life of Kirill, which possesses a concluding eulogy containing aspects of the humility topos. Though paromij again declares that the writing of Lives is a duty for those who can po dostoinstvu poxvaliti, 38 he twice refers to his ignorance and lack of education, 39 and three times to his sinfulness, 40 though never at any length. Together with a detailed list of his sources and the wealth of factual material, this creates the impression of an author concerned to put what talent he possesses to best effect in praise of a man he greatly admires. And yet even here the humility topos is not as exaggerated as in the Life of Stefan. Its relatively greater use in the Life of Kirill may have been stimulated by

36. p. $1 \times x \times i i i$.

37. p. $1 \times v$.

38. p. ii.

39. pp. iv and ixi.

40. idem. 
Paxomij's own admiration of Kirill or the high esteem in which the virtue of humility was held in the Monastery of the white Lake, where presumably the Life was commissioned.

Lipifanij's and Paxomij's divergent approaches to the humility topos are revealed even wore clearly in the Life of Sergij. Amidst the tangled web of redactions, one element emerges clearly; two quite different exordia exist. Une, found in the prostrannoje zitije in the Velikije Cet'i-fiinei (Redaction E) is clearly Epifanij's work. 41 In it Epifanij again laments his failings, explains why no-one could pluck up courage to write until twenty six years after sergij's death and encourages himself in his endeavour. is personal as the exordium in the Life of itefan (with which there are many direct parallels), this presents a mch clenrer picture of the worried uncertain author than the other exordium, which is found in Redactions A, B, V, G and D. Presumably composed by Paxomij, the latter contains no reference at all to the humility topos. lledactions $G$ and $D$ also include a short autograph in the concluding passage of the work, where Paxomij names himself, refers to the sources of his material and adds a token reference to his humility (he calls himself smirenny $j)$. Hedaction $\dot{E}$ on the other hand does not possess an abstract conclusion, a surprising omission in view of upitanij's predilection for panegyric. $^{42}$ lt is possible that in Lipifanij's original the conclusion

41. Hedaction $t$ is a sixteenth century compilation but the exordium contains evidence dating it to 1418,26 years after jergij's death. See Muller's introduction to Sergij von iladonež, $p p$. $x i i$ and $x \times x i v$. So self-evident is this, that it is surprising that honovalova in ' $K$ voprosu' takes Kedaction $A$ as Epifanij's, thus seriously undermining her conclusions.

42. Paxomij's autograph and brief eulogy were in the Ms of lledaction $b$ used by liakarij for his edition of V $K_{M}$, but were not printed because they repeated lledaction $U$, which precedes $E$ in $V X_{M}$. See $n$. to cols. $1563-4$. 
was furnished by the Enconiun to Sergij, now seen as a separate work. 43

The Encomium contains a vast number of odious comparisons between author and subject appearing at any stage in the relatively brief work. These are typical of Epifanij's excessive sense of inferiority.

Thus though some facets of the humility topos are to be found in most vitae written in pletenije sloves, the great emphasis laid by Epifanij on the gulf separating author and subject is a feature peculiar to his Lives. It was not prompted by bulgarian or Serbian models, but may perhaps have been by Kievan literature. For Nestor's Life of reodosij contains as many motifs of self-disparagement as Paxomij's Life of Kirill, and like the Life of Stefan abounds in references to the author's sinful nature and ignorance. In even closer parallel is offered by hirill of Iurov's prayers, in which the author's consciousness of his own sinfulness is the dominant theme, far more so than in the prayers in the liturạy. Kirill calls himself okajannys i mogogrěsnyju and complains:

аз же окаяннуи объят мнотеством злих грьхов, ито сттрорп невьд, или в кою пропасть себя вверг5.

(p. 319)

Compare Epifanij's plea to Cod:

да ми очистит сердие мое острупленое многыми струпи душевных вредов и телесных страстеи.

Both cry out uvy mere and lament:

(f. 653)

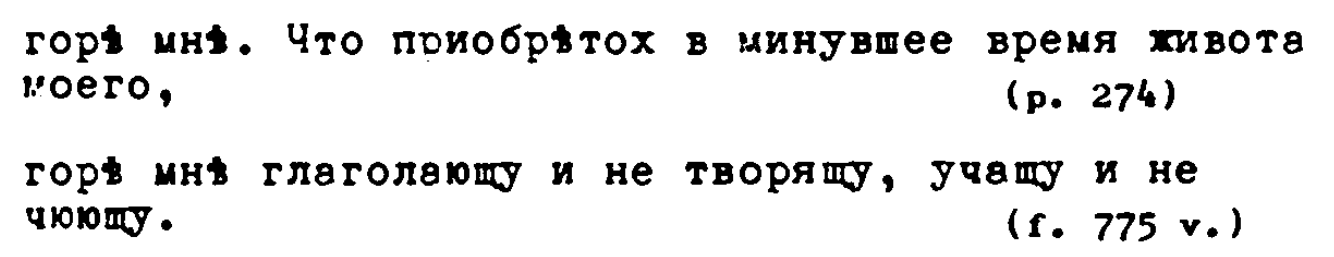

Like tpifanij, kirill does not know what he says, so enmeshed is he in wickedness, 45 and like Epifanij not only humbles himself before God:

43. This is a complex problem which cannot be discussed here in detail.

14. In kirill von Turov, lebete, roprinted from pravoslavnyj sobesednik of 1658, (Slavische propy18en), Wunich, 1965, p. 248, cr. mnogogresnyj i nerazumnyj, (Life of stefan, $f_{0} 770 \mathrm{v}$. ).

45. pp. 319,307 and many other examples. Cr. Li feithor nstier an7 8394793764 , $764 \mathrm{v} ., 776 \mathrm{ve}$ 
и како на высоту к Тебл вззтри сквернмма очима, (p. 238)

but also compares himself unfavourably with others:

$$
\begin{aligned}
& \text { ame 6о с свгрыших иного паче вс\$х qеловык, но } \\
& \text { от Тебе не отступих. (p. 255) }
\end{aligned}
$$

The tone of humility in Kirill's prayers is only one of a number of stylistic parallels. It would appear that muility was a virtue prized in the Kievan monastic tradition. Writers such as Feodosij and most particularly Kirill reflected this in their literary compositions through the development of a topos common not only to hagiography but also to other ecclesiastical literary genres. 46 The religious revival of the fourteenth century led to an even heavier emphasis on humility, again reflected in Kiprian's Life of Peter, Paxomij's Life of Kirill of Belozersk as well as Epifanij's vitae. Monastic teaching combined in Epifanij's case with an innate sense of sinfulness and unworthiness to produce a work permeated with pathos and lyricism. The traditional humility topos became a major element in the structural and stylistic framework of the Life of Stefan.

46. For example, Vranska (op. cit., pp. 83-6) lists a number of examples from inscriptions to copies or translations of ecclesiastical works. The humility topos may also be found in Kirill of Turor's Pritca 0 bělorizcĕ Čelovĕcé in żei trzahlungen, (slavische Propyluen, v), Munich, 1964, p. 131. 
The use of antithesis in the odiaeval literatures of the Orthodox Slavs ay be formally attributed to the joint stylistic influence of classical rhetoric and Hebrew poetry, but its popularity is to be explained by its intiuate connection with the nediaeval world view. For the world was seen in teras of opposites, good and ev1l, Christian and pagan, God and the deril, hearen and hell. Such attitudes contributed to the appeal of the Psalms; popular quotations often contain antithesis. There are, for example, no les, than fifteen such quotations from the Psalms in the Life of Stefan of Pers'. Some of these are simple phrases commonly found in vitae, ${ }^{1}$ but others are combined with the parallelist typical of Hebrew poetry by wich syntactically similar phrases reinforce the contrast. 2 Inevitably, original literature reflected these attitudes, such that both concise antitheses and broad structural contrasts abounds Ilarion's argument in the Jermon on Law and Grace, for exarple, rests upon a progression of antitheses. 3

But though all genres of ecclesiastical literature wake extensive use of antithesis, to none is contrast so basic as the vita. The rery concept of sanctity implies a contrast both with evildoers and with ordinary men; a contrast which found expression in hagiographical stereotypes. For example, the education topos described how the saint studied wore brilliantly than his contemporaries," while another emphasised his

1. For example, Ps. 125, iii, 'the rod of the wicked shall not rest upon the lot of the righteous', in the Life of Stefan $1.681 \mathrm{v}$., and employed by Domentian (quoted by Mobin, op. cit., p. 88).

2. For example I. 759 V., a quotation from Ps. 30, xi.

3. The nucleus of these antitheses is to be found in the New Testament. A dozen of the quotations from the New Testament in the life of Stefan include antithesis.

4. For example Life of Feodosij, p. 33; Life of Stefan, I. 654. 
rejection of childish pastimes for godly pursuits. 5 The humility topos is also based on a juxtaposition of opposites, 6 as is the puer/senex topos, which contrasted the youthful body of the saint with his mature wisdom anc understanding. This cliché evolved in late antiquity, rapidly passed into hagiographical literature and is found in vitae of diverse origin such as Gregory the Great's Life of Benedict, the Vita Constantini, the Lile of loan of Rila and the Life of Serqij of Radonez. 7 The paradox 'earthly angel and heavenly an' wich underlined the saint's special qualities was nearly as popular. 8

Apart from the contrasts between the subject of the vita and other men, mediaeval views are reflected in simple antitheses between heaven and earth, 9 life and death, ${ }^{10}$ visible and invisible, ${ }^{11}$ being and non being, ${ }^{12}$

5. For example Life of Feodosij, p. 43; Life of Sava, p. 121, Life of Steran, $F .654$.

6. See pt. II, chap. iii.

7. Life of Benedict quoted by Curtius in his history of the topos (op. cit., pp. 98-101); Vita Constantini, p; 6; Life of loan, p. 20; Life of Sergij, pp. 29, 49 of Leonid, zitije prepodobnago i bogonosnago otca nasego Sergi.ja Eudotvorca i poxval'noje emu slovo napisannyje ucen ikom ego Epifanijem Premudrym v XV v., (PDP, LVIII), St.P., 1885 quoted by CiZevśky, 'Lur stilistik', p. 110.

6. For example Life of Feodosij, p. 56; Passion and Dncomium to Boris and Gleb, p. 49; Encomium to Cyril and Methodius quoted by Vranska, op. cit., p. 199, and in Domentian's vitae, for example in the Life of Sava alone on pp. 181, 214, 223, 279, 306.

9. For example in the Vita Constantini, p. 4; Life of Petka, p. 74 ; Life of Ilarion of Maglen, p. 35; Life of Stefan, If. 671, $687 \mathrm{v.}, 704$.

10. For example in the Life of Filoteja, pp. 84, 89; Life of Stefan, ff. 680,767 .

11. For example in the Life of Sava, pp. 118, 235, 243; Life of Stefan, f. 671 .

12. For example in the Vita Constantini, p. 35; Life of Sava, p. 236, Life of Stefan, If. $676,700 \mathrm{v}$. 
body and soul (or corporal and spiritual), ${ }^{13}$ secretly and openly ${ }^{14}$ or great and small. 15 Such contrasts fore part of conventional Christian phrascology present in the liturgy and hence universally laniliar. ${ }^{16}$ Some, like visible/invisible are used not as contrasts but rather to convey completeness, as in the expression 'all things visible and invisible'. Unlike antitheses proper, these expressions are rarely developed or expanded.

Yet other pairs of contrasting concepts are symbols, not specific to the rita but comnon to all ecclesiastical genres. The most fruitful of these is the contrast between light and darkness, in wich light represents Christianity, truth, baptism and any number of related variants according to context. As Adrianova-Peretc showed, light way be any spocific forw of light, such as candles, the sun, planets and so on. The image of darkness usually represents ovil, heresy, idolatry, ignorance and so on. ${ }^{17}$ other inges which clearly derive from New Testament teaching

13. For exanple in the vita Constantini, p. 35; life of Sava, pp. 138, 261, 278 (twice), 279, 337; Life of Petka, pp. 173, 174; Life of Filoteja, pp. $79-80$.

14. For example in the Life of Mothodius, p. 93; Life of Petka, p. 171; Life of Stefan, ff. $677,695 \mathrm{v},, 692 \mathrm{v}$.

15. For example in the Life of Petka, pp. 162-3; Life of Stefan, f. $690 \mathrm{v}$; Life of Kirill of Belozersk, pp. ii, xiii. Full bibliographical references to these texts are given in the appendix of priaary sources, p. 290.

16. For example the body/soul antithesis (Kern, p. 301), heaven/earth (Kem, p. 222), visible/invisible (Kern, p. 214). References are to K. Kern, Evxaristija, Paris, 1947.

17. V. P. Adrianova-Peretc, Ǒ̌erki poetičeskogo stilja drevnej Pusi, M-L., 1947, pp. 20-35, discusses the variations on this imge in both folk and ecclesiastical literary traditions. It is extresely common ritae, for example in the life of Feodosij, pp. 58, 88; Life of Sava, pp. 128, 155; Life of loan of Rila, p. 16; Life of Ilarion of Maglen, p. 41; Life of Metropolitan Peter, p. 166; Life of stefan, If. $656,716,743 \mathrm{v}, 754 \mathrm{v}$. For the use made by Epifanij of these traditional images see pt. II, chap. vii infra. 
are the inages of barren and fruitful (generally applied to the symbol of the fig tree), and flowing water and dryness.

But whether antithesis emphasizes the unique qualities of the subject of the vite, or brings out facets of the Christian Weltanschauung, it is always subject to individual treatment through variation and amplification. Thus the traditional contrast between the body and soul of the saint 'in body a can, in spirit an angel. 18 may be adapted and expanded according to the wish of the hagiographer, as in Paxomij's Life of Kirill of Belozersk:

\section{Феодор стята велир вырЈ к святоиј

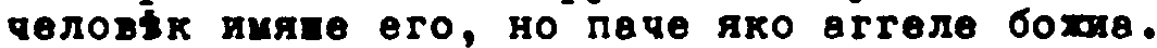

(p. $x \geq i)$

He was also at liberty to place antitheses of this type where he liked in his work, and to repeat them as wuch or as little as he 1 iked.

Dowentian's vitae serve as excellent examples of the extent of this freedow. For Domentian deliberately underplays the traditional contrast between the saint and his mundane existence, submerging reality in paeans of praise, and replacing traditional contrasts by poetic enumeration and comparison. Thus antithesis is extremely rare, while groups of synonyms abound. Indeed the only contrasting pairs employed with any frequency by Domentian are the traditional groups day and night, visible and invisible, which assist Domentian's concept of the vita by expressing the oneness of things. Such phrases are wch wore frequent than in the Life of Stefan of Perm'. Typical for Domentian's vitae is the epithet constantly applied to Sava and Simeon, 'earthly angel and heavenly wan', which epitorises his concept of the hagiographer's task. It is noteworthy that Epifanij never makes use of this expression. 19

18. For example in the Vita Constantini, p. 3 .

19. See note 13, p. 100 supra. 
These examples apart, antitheais is extrowely rare in Donentian's vitae: rhythicel proups are not uned at all except in the occasional borrowing from the liturgy as in:

помошь безпомоними, надекда неввдеюиимсе 20 Occasionally he expands a traditional contrast as in this effective exnple of his pletenife sloves:

по зиттны бо нареяе се домв тиваято бога,

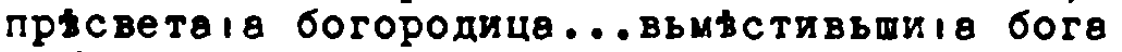
небесемв невьмьстиявго.

$$
\text { (p. 138) }
$$

Here assonance strengthens the traditional phrase to reinforce Dowentian's praise of the monastery founded by Sava on Mount Athos. Only in the rare parts of the Life which nake greater concessions to logical argument (in Sava's sermons), does antithesis play a larger role, as when Sava stresses the contrast between death and Christ's oift of imortality in the course of his condernation of Manichean heretics. 21

Though Sava's sermons are at times argument as well as invtruction, they fall short of the controlled reasoning presented by Ertinij in the Life of Ilarion of Maglen. They rely to a large extent on traditional phraseology, which had a familiar and comforting sound to it and hence they depend on emotion as wuch as logic. In this schewe of things antithesis, except for conventional pairs, cannot play an important role. In logical argurent, on the other hand, antithesis may be highly effective, a possibility exploited by Evtioij in the Life of Ilarion of Molen. where three quarters of the total number of instances of antithesis in the work are compressed into the polemic wich forms anly half of the total. In general, antitheses in Evtiend's vitae are not particularly

20. Frow the Liturgy of St. Basil, quoted by Mosin, op. cit., p. 89. The quotation may be found on p. 295 of Kern, Evxaristija.

21. p. 240 . 
striking or frequent; of a hundred examples given by Vranska, ${ }^{22}$ only a half could be easily picked out, 23 in sharp contrast to the large number of clear examples in the Life of Stefan (more than one hundred). In Evtimij's vitae, they are concentrated in exordium and eulogy and above a 11 , in the polemical sections, where they are drawn mainly from the New Testament perhaps through patristic writing. In the exordium they occur mainly in the humility topos, but since Evtiaij is not overwhelmed by feelings of inferiority and inadequacy, they are rarely expanded or arranged in patterns. In fact, the balanced contrast quoted here from the Life of Petka is one of the few examples of antithesis reinforced by pletenije sloves:

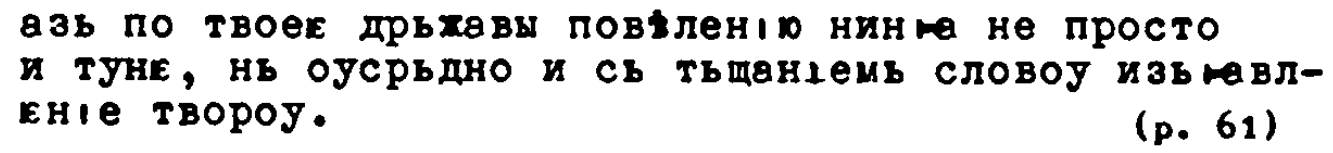

for Epifanij, antithesis is a stylistic foundation stone because the whole work is structured on a series of contrasts; between Stefan and Epifanij, Stefan and the Permians, Stefan and other men ${ }^{24}$ and Epifanij and the audience. 25 whereas in trtimij's ritae antithesis is most commonly found in the exordium, eulogy and in polemic, in the life it is essential to all parts of the work, though its intensity varies."

Thus antithesis is the basic structuring device of the concluding

22. op. cit. pp. 94-110. Purthermore, she incorrectly classifies comparisons with Biblical ficures as antitheses.

23. This $f$ igure is based on an analysis of the Life of Petka, but there is no reason to assume that the proportion is not true of the other vitae.

24. See pt. I, chap. i, supra.

25. See pt. I, chaps. i and iii supra. 
laments. 26 A lament is unavoidably based on a comparison between the

life of the bereaved before and after the death of the lamented, but

Epifanij sharpens the natural contrast in several ways; by enumeration

of emotive inages and comparisons, by structuring antitheses according

to Old Testament poetic traditions and by intensifying his pletenije

sloves. So, in the Lament of the Permian people, the Permians are

informed of Stefan's death, and upon seeing his clothes and belongings begin to mourn:

аме бихом злато потеряли или сребро, то иное в того мвсто обряшем, в тебе остввше, иного такова не обрлием.

(f. 748 v.)

They then discuss themselves in terms of the familiar Christian symbol

of the lost sheep, with its implied contrast with the peaceful flock and

its shepherd:

оставал еси свое си стадо заблутатися и скытатися по горви, горопленншм и волкохищним быти. Кому приказал еси стадо свое, ехе о пеств попечение. Кто ли төко, како ты, попечется нам, овцами заблуждьмими, не терпим бо бес тебе бити...

(1. 749 )

They lament the death of Stefan in Noscow, which they argue has many holy men while they have but one, and where he is not honoured as he is in l'erm'. 2 ;

26. The duthor's Lament depends largely on the humility topos. See pt.II, chap. iii supra.

27. f. 751. This passage has been taken as an example of Epifanij's anti-Muscovite feeling by Orlov, for example (op. cit., p. 245). I would see this rather as an artistic error on Epifanij's part. In his efforts to ensure that the Permians' Iament is emotionally moving, Epifanij makes them regret that Stefan did not die in Perm'. They contrast the number of church leaders and saintly men in Moscow with stefan, who alone fulfilled these functions for them. In their grief, they blame Moscow for taking him away. Epifanij achieves his aim with the modern reader, but it is doubtful whether even the poetic tenor of this passage would have been enough to convince a contemporary Muscovite. Further evidence to suggest that Epifanij did not intend this passage to be seen as ant $i$-Nuscovite may be discerned in his rejection of Stefan's nick-name of 'Xrap', which follows this passage ( $f .751)$. It is most unlikely that he would negate his efforts to justify stefan by a passage at tacking Noscow, which would have aliennted precisely those he fropedvidiconosinces.143 
These themes are wade more telling through pathos which heightens the contrast between the distress of the lost sheep and their former happy lot, between the glory of Moscow and the poverty of newly converted Perw'. Hathos is created through rhythmic enumeration and evocative neologisms as in the rhetorical exclamations above, or by syntactic parallelise:

к Богу не имам молитвеника тепла, к человыком те не имам заступника скора.

$$
\text { (1. } 748 \text { r.) }
$$

Like the first lament, the Lament of the Permian Church ewploys stylistic antithesis to bring out basic contrasts. Presented as a widow's lament, it paints a detailed picture of her loneliness and grief compared with the happiness of her wedding day. 28 Though based on a passage in Gregory of Nyssa's Lagent for Neletius, the contrast between 'then' and 'now' is considerably amplified and strengthened through parallelism:

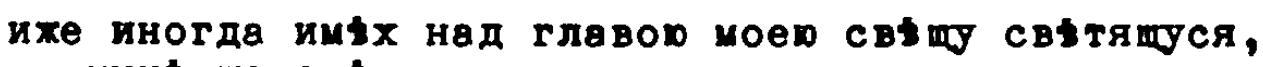

$$
\begin{aligned}
& \text { ихе иногпв имњх скровиче сокровена в сосудь глинянь, }
\end{aligned}
$$

These two pairs of phrases are only the first of a string of seven. But touching as the pictures of bereavement are, Epifanij could not end on a sorrowful note. In accordance with Christian teaching he provides both laments with an optimistic conclusion, again in the form of an antithesis; in the first with the theme 'even if you have departed from us in spirit, and though your grave be far away, yet may your prayers be with us always. 29 In the second, the Permian Church compares her intense grief with the solace she will receive from God. 30

28. For a fuller discussion of the relation between the antitheses in the Lament of the Pernian Church and in Gregory of Nyssa's Lament for Meletius, see lolthusen, op. cit., pp. 74-8.

29. f. 750 .

30. .. $760 \mathrm{v}$. 
The main narrative part of the Life differs from wost vitee in its use of thematic antithesis. The contrasts inherent in all hagiography are skilfully brought out by Epifanij. The nost persistent is between paganism and Christianity, hardly surprising since it is Stefan's conversion of the Permians that qualifies hil in Epifanij's eyes as a candidate for canonisation. The mission is drantised in stark black and white scenes; Stefan, gentle and cala is first seen amid a wildy shrieking crowd of unbelievers; then, as he begins to make converts, the contrast shifts to Christian and pagan Permians, and is underlined through Lletenije sloves. Stefan, Epifamij explains, 'was loved and honoured by the believers and converts', but:

невьрния ненавидына его и не qествовапе его и небрегоrв о неи.

The concentration of words beginning with the negative particle intensifies the effect of contrast while the use of the word nevernyj, unbeliever, rather than poganin, pagan, presents the unconverted Permians only in terms of a negative reaction to Christianity, and thereby diminishes the standing of their own religion in relation to Cluristianity.

The gradual process of conversion of the Permians is itself presented through a series of antitheses. The early converts are reviled by the unbelievers and even later, when Stefan has built his church, their reaction is both a contrast to those of the Christian commity and a surprise to the audience, who expect them still to be hostile. They come not 'to take part in the prayers or seek salvation... but to admire the beauty of the church'. 31 when finally the mass of the people cone orer to Christianity, Epifanij emphasizes the vast change wrought in their habits through Stefan's influence:

аще бо с яростио и гньвом прегде устремишася нань, но обаче увытевахуся в иир кротостию его, вще и с убияством и с дреколием прехде напвдова на ни но обаче благыми словесы его, и святыми учения его

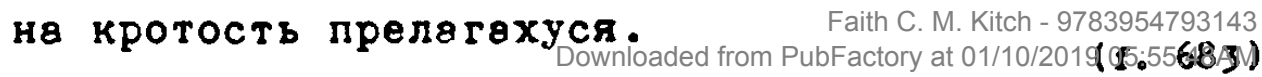


Likewise, the conflict with the shaman is presented in terms of contrast. When talking of the shaman's activity among Stefan's flock, Epifanij employs the negative particle in the same way as above:

невьрен сыи, не кренен, присно ненавидя выры крестивньскиа и не любя крестиан, некрешении убо пермяном $и$ невьрншм не веляше выровати и креститися, хотящим же выровати вззбраняше и зөпрешеше, вьровввших же и крестившихся разврашвше.

(1. $694 \mathrm{v.})$

luring the debate the spiritual values of Christianity are opposed to the materialistic religion of the shaman. As the two opponents undergo the trials of faith, the contrast between Stefan's faith and courage and the shaman's cowardice and deception clearly emerges. The final antithesis is between stefan victorious and the shaman defeated.

The comparison between pagan and Christian Perm' is closely connected with the opposition of paganism and Christianity. Enumerating the tangible results of conversion: churches and monateries built, priests ordained and helpers chosen, Epifanij underlines the contrast with the heathen temples of old Perm', concluding with a phrase that summarises his point:

\section{ихехе претпе бмли идолослукителг бьсомолцы, ту бого.отюты явишася. $\quad$ (f. $721 \mathrm{v.})^{32}$}

The same basic contrast is often expressed metaphorically, through the most flexible and fertile of symbols, light and darkness. Epifanij's quotation from Isaiah, 'the people that walked in darkness have seen a great light: they that dwell in the land of the shadow of death, upon them hath the light shined', is the essence of his oft-repeated likening of paganism to darkness and conversion to light. 33 Both this image and

32. See also Nestor's comparison between the paganism of the lisssians and their Christianity on p. 4 of the Lection on Boris and Gleb.

33. f. 736 v., from Is. 9, i i. 
the traditional antithesis between heavenly and earthly are ewbroidered and adapted in a way that makes them fresh and wemorable. So Stefan's church is beautiful not because of man's skill, but because of God's glory and the praises resounding within it. Lest the antithesis be too weak, Epifanij arranges the passage in parallel phrases. The use of the symbols of darkness and light shows that Epifanij, in spite of his efforts at making the ascesis vivid enough to convince, never forgets the general symbolic significance behind these events. Likewise, he points out that Stefan's offerings of refreshment to weary travellers were spiritual as well as physical:

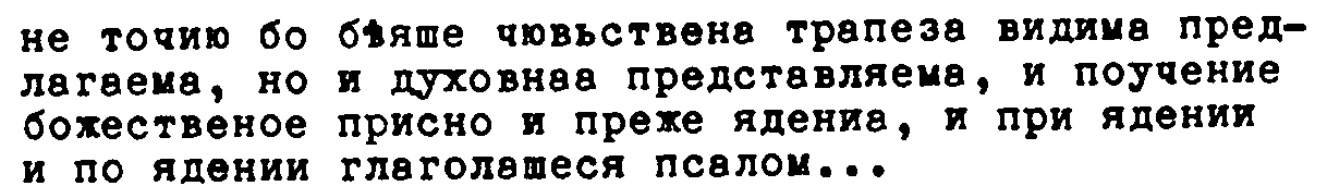$$
\text { (1. } 736 \text { v.) }
$$

A similar comparison between real and symbolical is found in the eulogy to Stefan at the end of the Life, where some of the numerous epithets Epifanij applies to Stefan, such as doctor or warrior require a symbolic interpretation. 34

vother important antithesis in the Life is contained in the eulogy to the creator of the Permian alphabet, in which inventors of the Greek alphabet are compared unfavourably with stefan, who succeeded in composing an alphabet for the Permians by himself and in a relatively short space of time. 35 Since Epifanij's aim is to glorify Steran and only to denigrate the Greeks in comparison with him, far greater weight is given to the side of the antithesis that praises Stefan's achievement. Thus the passage contains the most brilliant example of Epifanij's pletenije sloves, the interweaving of words derived from edin (one), in praise of

34. If. 771 v. and $767 \mathrm{v}$.

35. The 'outdoing' topos. See Curtius, op. cit., pp. 162-5. 
Stefan. The same method is employed whenever Epifanij considers one aspect of the antithesis artistically more important.

The abundance of antitheses in the narrative part of the Life does not permit their exhaustive treatment. Some serve to praise Stefan,as when Epifanij emphasizes that he did not seek high ecclesiastical office 36 or when he is compared favourably with Joseph of the Old Testament who sold corn to the Israelites in Egypt, while Stefan not merely gave it away but succoured them in mind as well as body. 37 Such comparisons were not merely possible but even desirable in hagiography because of the superiority of the Grace of the New Testament over the Law of the 01d. 38 Antithesis may also increase the element of dramatic surprise as when Stefan (and the audience), led to believe his death at the hands of hostile Permians is imminent, prays and is miraculously spared. Where violence was expected, now 'no-one laid a hand on him, nor was he beaten or struck by anyone, being saved by the grace of God' 39

Few of the many instances of antithesis in the Life are arranged in tight rhythmical patterns. At first sight this seems surprising, since antithesis, with its natural division into two parts would lend itself easily to rhythmic arrangement, but not so surprising when it is remembered that contrast is a basic structural device. is a result, antitheses are usually long and do not lend themselves easily to balance. Nonetheless, as examples already quoted show, a certain degree of rhythm

36. With such emphasis that the modern reader receives a clear picture of corruption in the Pussian Church at that time. It is a further instance of Epifanij's artistic naiveté, for all its interest to the modern scholar.

37. f. 736. Another example of the 'outdoing' topos.

38. See Manson, op. cit., p. 204 .

39. f. 681. A180 f. 720 . 
and aytactic parallelisa is often present, ${ }^{40}$ sioply because the Life is composed throughout in an ormate style. Only in the Laments, where Epifanij unleashes all his poetlc talent on his audience to ovoke their veneration for Stefan, are there ming concise balanced antitheses. Epifanij makes greater use of antithesis than either Domentian or Evtiaij, because he views the rita as aeries of contrasts desicned to demonstrate Stefan's moral superiority, and render the account of the mission drawatically effective. Thus most antitheses are broad structural contrasts which adhere less obviously to tradition than those in other Iitae. When Epifanij turns to conventional foras, he frequently develops them at aming length. For examle the traditional prayer formula, quoted on page 108, pomošč bezponoščnym is frequently found in vitae in groups of two or three, 'but in Epifanij's Author's Lasent, nineteen such phrases are strung together. 42 Once again he has taken mximum advantage of the freedom of the mediaeval hagiographer to operate within the traditional literary framework of the rita, in the hope of convincing his audience of Stefan's sanctity.

40. pp. $10+-8$ aupra.

41. For example, the Life of Feodoaij, p. 89.

42. $.770 \mathrm{v}$ 
CHAPTER V Epifanij's method of composition and his attitude to the Scriptures

So intricate are some of Epifanij's word patterns, that it seems improbable that he could have composed freely, and yet the tone of the Life, with its impassioned protestations of unworthiness, its lyrical praise of Stefan clearly suggests spontaneity. ${ }^{1}$ The apparent contradiction can be resolved by establishing Epifanij's method of composition. Comparison of the wording of biblical quotations in the Life with that of biblical texts copied before the end of the fourteenth century served as the means to this end, because before the end of the fifteenth century, the Bible was only available in various texts of two basic types: liturgical and non-liturgical, that is either for use in services or for private reading. It could be assumed that Epifanij knew the liturgical texts almost by heart, because like all monks, he heard them repeated over and over again in the monastery. On the other hand, he would only have used non-liturgical works for reference, and thus be less likely to know them so well. If it could be demonstrated that, firstly, quotations in the Life are drawn largely from liturgical texts and secondly contain mistakes of memory rather than copyists' errors, then Epifanij was quoting from memory. If so, then he composed freely. Biblical quotations in the Life fell into two categories: biblical reminiscences which permeate the work, and may come from the Bible directly, from the liturgy or from translated and even original literature. Such reminiscences would have been absorbed into the vocabulary of any monk, and there seems little doubt that they are employed without reference to source. They are not, therefore, of value in determining Epifanij's method of composition. ${ }^{2}$ The second type are those used by

1. This chapter has been published in slightly modified form under the name $F$. Wigzell and title 'Citaty iz knig svjašcennogo pisanija $v$ soX' inenijax Epifanija Prewadrogo', TODL, XXVI, L., 1971 , pp. $232-43$.

2. The dividing line between quotations without introductory phrases and reminiscences is very $f$ ine. In general, whole clauses have been accepted as quotations, and this appears to have been the method adopted by Družinin. 
the author in the full knowledge that they are quotations, either introduced by words that make their origins clear ouch as rece prorok, Spas reče, po rekšew or occasionally woven into the text or wore frequently into Stefan's speeches without reference to their origin, but wich are recognisable as quotations. These coincide wore or less with the quotations traced by Družinin for his edition of the Life, and were used in this analysis. 3

The variety and composition of liturgical and non-liturgical texts in Russia is somewhat confusing: some were compilations, which did not preserve the original order, some contained more than one Book, others were editions of single Books. Some were service books, others intended for private reading. The contents of the two were not necessarily the same. Thus the service book containing extracts from the Old Testament, the Parimejnik only coincided to a minor extent with any one of the nonliturgical texts. The non-liturgical Istoričeskije and Tolkoryje Palei were concerned with Old Testament history (and its interpretation) and were therefore based on the Pentateuch and the Historical Books." ${ }^{4}$ Other extracts of a historical nature were found in translated Byzantine chronicles and in sborniki of a didactic nature. The following Books were known in toto in separate editions: the Pentateuch, Judges, the Mrelve Minor Prophets, Proverbs, the Wisdom of Solowon, Ecclesiastes, the Sang of Solowon, the first chapters of Kings and the Psalms. The latter were employed extensively in services (the SluŽbnaja Psaltyr') and were also know in two non-liturgical forms, the Gadatel'naja and Tolkovaja.

3. A few of the quotations have been wrongly identified (eg, 1.699 , given as Mic. 7, xi i 1.704 as Ps. 115, iv) and there are a nubber of omissions (eg, f. 679 from Ps. 36, xv. Also f. 675, a quotation from Psalms and 1.704 v. from Jeremiah).

4. The IstoriČakaja l'aleja recounts 0 . T. history up to the end of the Second Book of Samel, the shorter version only to I jamuel, 5, iil. 
concerned with divination and interpretation respectively. 5 The New Testawent was divided into the Gospels and the Apostol, and each was available in liturgical and non-liturgical versions.

The problem of selecting manuscripts of biblical texts was a considerable one, since naturally it is not know which redactions or copies Epifanij knew. In the course of time, copyists' errors inevitably became more common, particularly in liturgical texts which were copied more often. 6 It is not possible therefore, to assume that Epifanij quoted from memory merely because his version of a quotation does not coincide with that of a certain liturgical manuscript. But by consulting as many variants as possible, it would be clear when he was quoting from memory, because the differences would not only be greater but of another type. For the Psalter, a fourteenth century manuscript of a SluŽbnaja pgaltyr' was taken as a basis. 7 where the text of the Life of stefan diverged, comparisons were made with a Tolkovaja ${ }^{8}$ and a Gadatel'naja Psaltyr 9 and with variant readings in Anfiloxij's edition of the early Russian Psalter. 10 For the Gospels, Voskresenskij's edition of the Mstislav aprakos Gospel of the early thirteenth century was used with

5. Istorija russkoj literatury, I, p. 66.

6. L. P. Zukovskaja in her article 'Pamjatniki pis'mennosti tradicionnogo soderžanija kak lingvističeskij istočnik', (Issledovanija po 1 ingvističeskoma istočnikovedeni.ju, ix maと̌enije i metodika issledovanija, M., 1963, pp. 20-35), showed that there were numerous differences between copies of the Gospels, and discussed classification into redactions.

7. MS fp 1. 2 in the Saltykov-ŠČedrin Public Library, Leningrad.

8. MS fp 1. 23, the Tolstovskaja Psaltyr' (XII-XIIIth century) in the Sal tykov stedr in Library.

9. MS Sof. 60, XIVth century, Saltykov Ščedrin Library.

10. Drevle-slavjanskaja psaltyr' XIII-XIV v., I-II, M., 1874-7. 
variant readings from early and later muscripts in the same edition, ${ }^{11}$ and his edition of the Apostol was employed for those Books for which it was available. ${ }^{12}$ of the four redactions given by Voskresenskij, redaction A was selected as the basic text, but since this was a Tolkovyj Apostol (of 1220), variant manuscripts of redaction $A$ were also used. 13 Amfiloxij's edition of the Karpina Apostol of the thirteenth century was taken for quotations from all other books. ${ }^{14}$ Finally, quotations from the 01d Testament, other than those from Psalms were compared with the text of the printed edition of the Parimejnik ${ }^{15}$ and the palei. ${ }^{16}$

Although quotations from all Books of the Bible used by Epifanij in the life were compared with quotations from corresponding biblical manuscripts, those from the Psalter were subjected to the closest scrutiny, firstly because they are more numerous than those from other Books (158 out of a total of 340 ), secondly because both liturgical and non-liturgical

11. G. A. Voskresenskij, Evangelije ot Marka, Sergiev Posad, 1894. Unfortunately he did not complete an edition of the whole Gospel, but the completed sections were sufficient for this analysis.

12. idem, Urevneslavjanskij Apostol, Sergiev Posad, 1893-1908. Pt. I contains Romans; pt. II, I Corinthians; pt. III, II Corinthians, Galatians and Ephesians.

13. Redaction B was also consulted. The basic $A S$ of $B$ is the Tolstovskij ipostol of the XIVth century, but many of the variants are of a later date than the Life of Stefan and so had to be ignored: redaction $G$ was the Gennadij Bible of 1499 and $V$ was hleksej's translation of the New Testament (Cudov), which had many unusual readings and differed considerably not only from $A$ and $B$ but also from quotations in the Life.

14. Urevle-slavjanskij karpinskij apostol XIII veka, I, pts. i and ii; II, pts. i and ii, M., 1885-6.

15. R. F. Brandt, 'Grigoričev parimejnik $v$ sličenii s drugiai parimejnikami', CoIDR, M., pt. i in no. 1, 1894, pp. 1-90; pt. ii in no. 3, 1894, pp. 91-178; pt. $i i i$ in no. 2, 1900, pp. 179-290; pt. iv in no. 2,1901 , pp. 291-308.

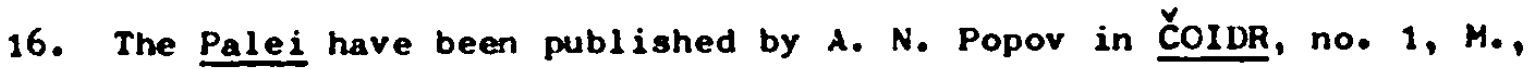
1881 . 
psalters preserve traditional contents and order, making comparison simple and convenient. Thirdly, the psalms were better knom than other Books in fourteenth-century Kussia; ${ }^{17}$ they were read in full each day in monasteries in Kussia and the Balkans, ${ }^{18}$ and Epifanij himself tells how meals in jtefan's house were always accompanied by readings from the Psalter. 19 It may therefore be assumed that Epifanij knew the psalms by heart and if quoting from memory would have reproduced fairly closely the text of the Služebnaja psaltyr'.

On examining the origin of quotations from the Old Testament (except those from Psalms), it became clear that Epifanij took his quotations from the Parimejnik, and therefore was in all probability quoting from wemory. Only eight of the quotations from the Old Testament in the Life might have come from the Palei, and of these four are also found in the Parimejnik.

Only ten quotations out of forty-three could have come from the Books of the Old Testament known in full and no more than three from any one Book. This is consonant with the statement that 'an analysis of quotations from these Books in Kievan literature shows that the Parimejniki and the chronicles furnished the highest proportion'. 20

17. Although specific extracts from other Books might be better known, no other Book was so familiar in its entirety.

18. Rad. M. Grujić, 'Palestinski uticaji na sv. Savu', Svetosavski sbornik. 1, SKA, CXIV, 47, quoted by Mulić, 'Srpsko pletenije sloves', p. 123. The popularity of the Psalter in Russia is asserted by $i . K$. Gudzij, Istorija drevnej russkoj literatury, M., 1956, p. 25, and A. S. Orlov, op. cit., p. 37 .

19. $.736 \mathrm{v}$.

20. Istorija russkoj literatury, I, p. 66. There is no reason for considering the position to be different in the early Muscovite period, which largely continued Kievan traditions. Extant MSS of biblical texts for this period show the enormous popularity of liturgical over non-liturgical texts. 
On the other hand, twenty nine of the forty three quotations from the Old Testament in the Life were found in the Parimejnik. This ouggests that Epifanij was quoting from memory from the Church texts he knew already. Furthermore, because extracts in the Parimejnik are selected to illustrate and reveal the meaning of festivals, they are similar to Epifanij's ow use of quotations. He seldom quotes narrative passages, and if he does refer to Bible stories, he normally paraphrases them. His knowledge of these stories came from the Istoričeskaja paleja or translated Byzant ine chronicles, but his quotations are selected primarily to illustrate points or highlight enotional passages and are therefore closer to the Paribejnik. 21 Even within the Parimejnik he reveals a bias towards extracts from the Prophetical or Poetical Books: Genesis for example, from which many extracts are taken, does not figure at all in the Life of Stefan, whereas Isaiah is the source of seventeen out of forty three. 22

The fourteen that are not found in the Parimejnik may come from sborniki and translated chronicles. Since one third of the total number of Old Testament quotations did not spring from service texts, it could only be said that Epifanij took a majority from the one text he might have known by heart. To confirm this tentative conclusion quotations from Paalms in the Life were compared with all types of Psalters. Very few were closer to the Gadatel'naja or Tolkovaja Psalters than to the Slutebnaja. The following example was the only one where the text of

21. See pt. II chap. vi, infra.

22. It is possible that some of Epifanij's numerous quotations from the Psalms could have come from the Parimejnik. In either case he would have been quoting from memory. See infra on quotations from Palms in the Life. 
the Life was identical with that of the Gadatel'naja Psalter and not with any other. Compare:

исполнится вся земля слвви его: будеть и будеть, (f. 723 from Pa. $73, x i x)^{23}$

with the text of the Gadatel'naja:

исполниться вся земля славу его: будеть будеть,

wheress the basic text of the Služebnaja (fp 1.2) reads

исполниться слвви ето вься земвля будетв будетв,

and the Tolkovaja and variants from Amfiloxij placed ego after zemlja. Since this example is unique, it seems that Epifanij remembered the quotation inaccurately rather than copied.

There were no examples of a correspondence with the text of the Tolkoraja alone.

In another instance, although initial researches suggested that he had made use of one of the texts for private reading, further scrutiny showed this to be incorrect. The passage in the life reads?

блажен яанк, еиуте есть Господь Бог его, и лоди, я избра в достояние себн

(f. 723 from Ps. 33, xii)

whereas fp. 1.2. had:

блвжен язик, еијхе есть Господь Бог его, люди, яхе избвра в насльдне coб

and toth the texts of both the Gadatel'naja and Tolkovaja Psalters gave dostcjanije. But examination of the variants in Amfiloxij revealed that the use of the word nasledije was a feature of MS. fp 1.2. only, and therefore, since all three versions usually read the same, the example was nconclusive. while this poverty of examples of identity with texts

23. In each case, the reference to a psalm is given according to the numbering in the Authorised Version. This explainsait heMchanges39ingun-

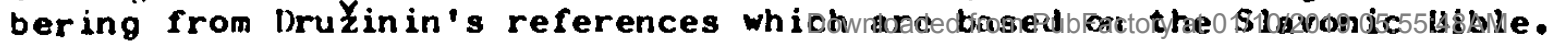


for private reading suggested that Epifanij did not use thew, this did not prove that he used the Sluzebnaja, since in any cases all three Palters had identical readings. Nevertheless careful scrutiny revealed other examples of identity with the SluYebnaja alone:

csine с слезани в радости пожнут.

$$
\text { (f. } 667 \text {. from Pa. 126, v) }
$$

The SluZebnaja Psalter (fp 1. 2.) has an identical reading except for the spelling of sêjušči:

сьндеи со слезвми в радости пожьнуть,

while both the others read:

сьявшеи спьзвми в радости потнть.

All in all, nearly half the quotations from the Psalms in the Life of Stefan were identical with the text of the SluZebnaja Psalter, either as found in MS Ip 1.2. or in the variants in Anfiloxij. This proved that Epifanij took his quotations from the version of the psalms that he knew from his monastic life. It did not yet prove that he did not refer to the SluYebnaja when composing the Life.

Examination of Epifanij's errors in quotation revealed that over a third of the quotations from the Psalter differed from any text of the Psalms. This was somewhat surprising in view of accepted notions about the excessive respect paid to tradition in early Hussia. The idea that the Scriptures as the repository of eternal truth could not be altered was strongly held in Hasia and the Balkans in the fourteenth and fifteenth centuries. Only a few years after Epifanij wrote the Life, Metropolitan Kiprian was exhorting his readers:

аме ли кто восхощет сия книгу преписывати, сматро̆и не прилотити или отлолити едино нькое слово, или тмұку едину или крючьки иже сЈть под строквми в рядех ни хе пременити слогию некоторую или 


\begin{abstract}
прилокпти от обичних иххе первее привик, или пвки отлогити ии в дьяконьствах нихе в взаглепеииях ни в молитвах, но С великим вниманием протитати и Јчитись или преписивати яко да не от небрехения грех впвдвете, занехе ехе от небрехения впасти в грех, горший есть, нехе от невидения биввемвго.
\end{abstract}

(Kiprian's služabnik) ${ }^{24}$

In light of such attitudes, it rould be natural to assume that Epifanij would have taken great care to ensure the accuracy of his quotations from the Scriftures. Thus the large number of errors adds to the evidence that he quoted from memory and was unaware of his mistakes. It is not feasible to conclude from this that he was indifferent to the need for accuracy in quotation, since he betrayed his veneration for the Bible in the vast number of quotations in the wife. 25 .

Copyists inevitably made mistakes leading to major differences even in biblical texts. 26 The mistakes of one scribe were incorporated by the next into his own copy together with some of his own making, and over a long period of time the number of deviations built up. Were Epifanij copying, the differences between quotations from Psalms in the Life and the text of the original should have been no greater than the differences between two copies of the Služebnaja. Furthermore, the mistakes should be typical copyists' errors, as classified by Lixačev in his Tekstologija. ${ }^{27}$ Though he was discussing the copying of a complete work, the types of wistake Epifanij would have made were he copying out passages from the Bible would be similar. In the event, only tro of Lixačer's categories were

24. Wuoted by I. Hansvetov, Mitropolit Kiprian v ego liturgičeskoj dejatel'nost i, M., 1882, p. 72 .

25. See rt. II, chap. vi.

26. ̌̌ukorskaja, op. cit.

27. M-L., 1962, pp. 56-81, and Tekstologija, Kratkij oterk, M-L., 1964, pp. $22-30$. 
relevant. 28 One of these, misreadings, like confusion of similar words, haplography or dittography, might have occurred had Epifanij been copying. There were however no errors of this type. Though omissions (haplography) were to be found, they conformed to the types of error classified under the other group, mistakes of memory. Copyists' errors occur when the scribe misses out words with the frequent result that the passage ceases to make sense. Most quotations in the Life, however, are very brief, and omissions never distort the meaning. As a result they are more likely to be slips of memory, made when the scribe memorized a passage in the original immediately prior to copying it out. Such mistakes, which are of several $k$ inds, occur wore frequently when the sentence or passage memorized was both long and unfamiliar. Errors are usually of the following kind:

i. Nistakes in the form of verbs, eg skazav/skazal.

ii. Omission, transposition or addition of conjunctions (especially the conjunction i) or pronouns (especially ja).

i i i. Transposition of words.

iv. Replacement by a synonym.

Lixačev points out that errors $i$ - iv can all be deliberate, in which case they form a system.

v. Modernisation of a text with archaic features.

vi. Unfamiliar phrases replaced by more familiar ones or by clichés.

28. The other categories were not relevant for various reasons. Mistakes that reflect the scribe's pronunciation or orthographical peculiarities cannot be traced because Epifanij's own copy of the Life is not extant, and it is impossible to distinguish his peculiarities from those of successive scribes. Nor do we know what were the special features of the Služebnaja Psaltyr', known to Epifanij and used if he were copying. Errors resulting from the scribe's ignorance of the text concerned, including pereosmyslenije, interpretations arising from a misunderstanding of the original, do not apply to familiar and carefully copied biblical texts. Misinterpretation was only possible when a particular phrase was in comon use already, in which case Epifanij mig!ıt use it regirdless of whether he was copying or not. 
Mistakes of memory of all the kinds mentioned above might occur whether Epifanij was copying or not, but there should be differences of degree. If the text were before $\mathrm{him}$, then it was not because he was totally unfamiliar with it. He therefore should have had little difficulty in memorizing a passage correctly before writing, especially as the average quotation from Psalms in the life is only the length of one verse. It is therefore to be expected that if he were copying out his quotations, they would be fairly close to the original, and the shorter they were, the closer they should be. If, on the other hand, he was quoting from memory, large numbers of mistakes would occur, many of them serious. In view of mediaeval reverence for the Scriptures, only the supposition that Epifanij was quoting from memory would explain away large numbers of striking deviations from the text of the original. In the event, the quantity and quality of differences between the Life and the SluZebnaja Psaltyr' far exceeded the variations between copies of the Psalter as well as those between the SluYebnaja, Gadatel'naja and Tolkovaja Psaltcrs. Differences between the three Psalters were minor, and typical of copyists' errors such as the addition of $\underline{i}$ :

$$
\begin{aligned}
& \text { iS fo 1.2.: послв слово свое и исцвли я, избави от } \\
& \text { пагубы их, (Pв. 107, xx) } \\
& \text { Tolkovaja: посъла слово свое о исцвлия, й избвви } \\
& \text { я от пагубш } \mathrm{x} \text {, } \\
& \text { Gadatel'naja: после слово свое и исцьли } \\
& \text { я от пагубы nx, }
\end{aligned}
$$

or the substitution of one word by another, as in the example cited on page 124, where naslědije replaces dostojanije in $M S$ fp 1.2 . $\lambda$ word might be added or omitted. Compare:

MS fp 1.2.: увыдите, яко Господь тв есть Бог нашь, (Ps. 100, ii i)

Gadatel'naja: увыдите, яко Господы тв есть Господь Бor Hanb. 
Further it ust be enphasized that these versions are not copied one Irow the other; each has its own history of separate developent. This means that differences result from errors made by numerous scribes over a long period of time, producing frequent striking variations. Spifanij's mistakes were far greater, and must be attributed to his faulty memory. Minor conventional mistakes of wenory of the types listed on page 127 occurred frequently; there were several exarples of the addition or omission of words such as $\underline{i}$ and the first person pronoun in its various flexional forms. These in themselves did not prove he was quoting from memory, but their frequency provided a guide to his method of composition. ts wentioned above, almost one third of the quotations from Palms in the Life of Stefan, fifty two out of 157 differed not only from manuscript fp 1.2, but also from any of the variant readings given in Amfloxij's edition of the Psalter, and thus definitely seemed to be mistakes of Epifanij's ow making. A further thirty differed from MS IP 1.2, but were found in at least one of Amfiloxij's variants dating from before the end of the fourteenth century. No-one knows which manuscript was familiar to Epifanij at the time of writing the Life, and therefore it is impossible to state firmly that these thirty mistakes sprang from the copy or were Epifanij's own. 29 since they were mainly slight deviations, they could just as well be either, and most probably some were attributable to the copy and some to Epifanij. Nevertheless the percentage of inaccurate quotations was higher than expected if he were copying.

Furthermore, Epifanij's mistakes extended beyond those made by scribes memorising a short extract before copying it out. There were five examples of the replacement of a word by a near symonym, as:

29. There were a few examples of a variant being obviously a feature of fp 1.2 alone, as mentioned supra, p. 11?, but these were the exception. 
яко не попусти Господь хезля грышнхх нв хребих преведних, (f. 681 v. from Ps. 125, iii)

whereas MS fp 1.2 read:

яко не оставить Господь хезля грышных на хребии праведних,

and Amfiloxij does not give any examples with popusti. In one instance however, a whole phrase was altered:

простри ярость твор нв язики незналаев тебъ...

(f. 702 v. from Ps. 79, vi)

while all copies read:

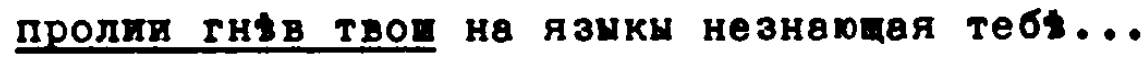

(MS fp 1.2)

There were several instances of addition or omission of words:

яко ты Господп, един вмшнии во всев земли,

(1. 723 from Ps. 97, ix)

where MS $\underline{\text { fp } 1.2}$ read:

яко ти Господи, выпьвии по всев земли.

Epifanij added the word edin to stress the meaning of his quotation, and of the passage in which it is found; praise of God and rejoicing at the multitude of people who have found Him.

In other instances he omitted a whole phrase:

вси языци обшедше, обидоша мя яко пчелы сот, и рөзгортшеся яко огнь в терния.

$$
\text { (f. } 672 \text { v. from Ps. 118, x-xii) }
$$

Compare MS fp 1,2:

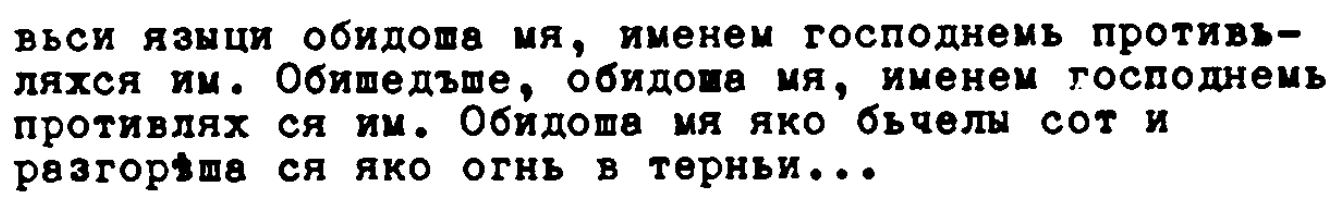

Here Epifanij appears to have remembered the beginning and the vivid simile at the expense of what went in between. It is unlikely, were he copying, that he would have omitted a passage written in a rhythmical 
style sinllar to his pletenije sloves. On the other hand, onission is one of the comonest fault of those copying or reciting from menory, especially when the passage to be remenbered is not rhywed or wotrical. A repetitive section (as in the ernple above), is wost likely to be forgotten while a striking image is retained in the memory. In another example, Epifanij rewebered only the introductory phrase, the beginning of the central part and the final phrase which forms a climax in the original:

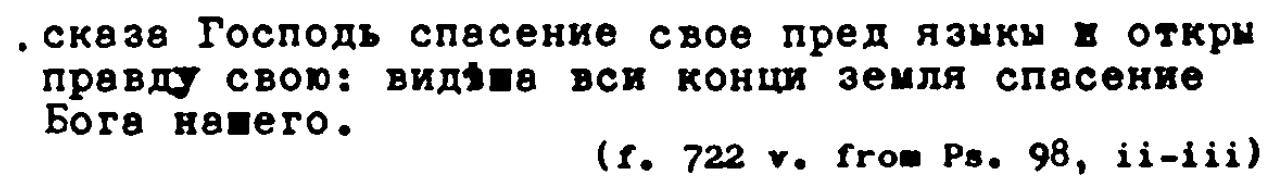

NS Ip 12,2 read:

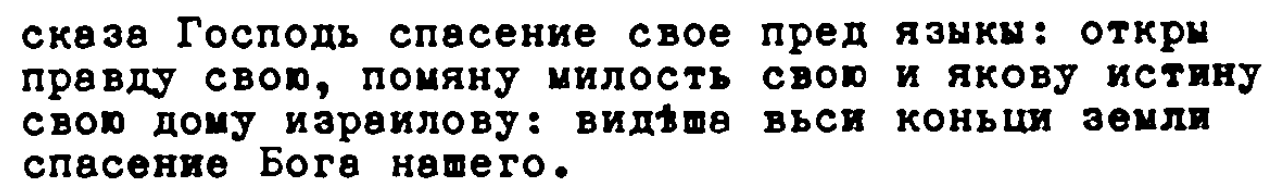

The reason for the omission is the same as for the previous example. The final statement is the most important in the context of what Epifanij is writing. The passage in the Life deals with the number of people who worship God and know his works, and the emphasis is on 'all peoples'; hence the importance of the phrase in the original which echoes this sentiment. The middle section of the quotation faded from Epifanij's memory, as the beginning and end emerged clearly. It is highly unlikely, were he copying, that he could have omitted such a large proportion of a short quotation.

In long quotations, his mistakes were more nuwerous. 30 Eramination of the few Iong quotations from Psalms in the Life of Stefan showed that none were completely accurate. However since he knew them well, he made

30. See Lixačev, Tekstologija, p. 68 . 
fewer nistakes here than in quotations from the New Testament, 31 where even fairly short quotations differed considerably from the original. Sometimes the result was a half remembered approximation, as in the following extract from II Corinthians 6, xiv-xvis

кая qacrs ecrs casts co тmор или кое причacrue есть вырия с невцрнии или кое обпение иеркви

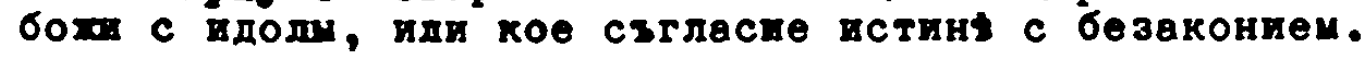

$$
\text { ( } 1.684 \vee .)
$$

which bore little resemblance to the originals

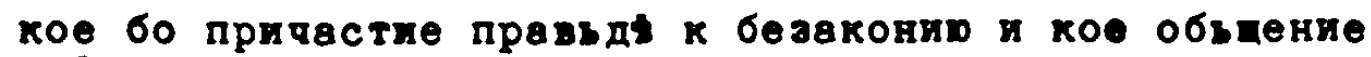
свнту к тви, кое те сзвынание хрнстови к веливру, или кая часть вырну с невьрнти пли кое сзлотение церкев ботет с кумири.

(Vookresenckij, variant A)

Such exapples were not unknow in panlw quotations. There was one example of a quotation introduced by the words David reče, and so intended to be accurate rather than an echo of biblical phraseology, 32 but where the order of the first and last phrases was reversed and the widdle owitted. In the Life it reade: хльб сердие человыку јкрипит, а вино возвеселит. (x. 760 from Ps. 104, xr)

Compare:

вино взавеселить сердие qеловику, умасти лиде ольен и хльб сердие человьку укрыпать.

(MS IP 1.2)

It is clear that a wistake of this type is too serious to be a mere copyiat's error.

Added proof was given by the fact that Epifanij used the same quotation twice, each time varying the form. The example above from the second epistle to the Corinthians occurs again in the Life in this slightly

31. Short extracts were appointed for reading in Church each day, but the New Testament was not read in full regularly like the Psalter.

32. The same is true of the previous example. 
modified form:

кое бо причастие свнту ко тин или кая обиинв в рнуу с невьрным.

(f. 714 froe 11 Cor. 6, xiv-xi)

In another example from Psalms the differences were slighter. As given in dmfiloxij, this quotation from Ps. 82, v reads: 33

не увыдыв ни разуитпвв в тьмы ходять.

In the Life the two versions were:

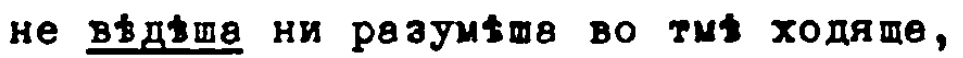

(f. 663)

and:

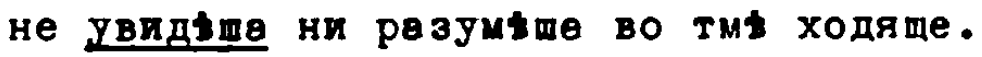

(f. 673 v.)

The two verbs vĕděsa/uviděs̆a may have been produced by the various scribes who copied the Life before the sixteenth century when the manuscript Družinin published was copied; uviděsa might originally have read uvěděsa. .lternately, since uviděsa is a variant reading (found for example in the Tolkovaja Psaltyr'), Epifanij may himself have employed two different verbs. Even if he did not, he mast have employed different aspects of the same verb, from which it follows that his memory failed him.

The similarities between the two versions should also be noted. ilazuměsa is found in Amfiloxij, but vo tme xodjaǧ̌e is peculiar to Epifanij. Someone copying would not make the same mistake twice, but someone rcciting from memory is very likely to memorise a passage incorrectly and always quote it wrongly. The presence of the two identically worded misquotations is further proof of Epifanij's method of composition. I few further facts can be added to the accumulated evidence that Epifanij quoted from memory. For example he introduces a quotation with the words glagolet lsaia prorok, but as Družinin points out, this text

33. This passage was missing in its fp 1.2. 
is nowhere to be found in Isaiah. 34 Epifanij forgot the source of the quotation and did not attempt to check. Another piece of evidence is the large number of quotations taken from the first verse of a psalm. It is normal when reciting from memory to remember the first lines of a poem or piece of prose; witness the number of people who can recite the first line of a poem or Shakespearean passage. Of course, it might be argued that Epifanij came across these lines first when earching for suitable quotations in his psalter, but it seems more probable that, if he were going to make the effort to find apposite illustrations to his text, he would not select those he saw first.

In spite of mediaeval ideas that the Bible was sacrosanct, and should never be tampered with, it has been seen that Epifanij's quotations differ from the original, and that these differences are more consiuerable and more frequent than is normal between two manuscripts of a biblical character. Epifanij quoted from memory.

There seemed no conscious reason for the variations examined above, but some other quotations had obviously been adapted deliberately for reasons of sense or style. While some may be unconscious elips, in the overwhelming majority of cases it was impossible to give Epifanij the benefit of the doubt. Deliberate alterations might be minor, but could also be adaptations of passages several verses in length. They fell into two basic categories; those that were changed for semantic reasons, and those for stylistic reasons.

The first type involved changes of person, as in the following example, included in a passage in which Stefan prays for deliverance from the savage Permians who threaten death. The original quotation read:

34. f. $699 \mathrm{v}$. There is another example on f. 702 of a quotation incorrectly attributed to Noses. 
и бысть Господь прибв киме убогому: помощник

в благоврвмя в печвльх...

(MS $\left.f_{P} 1.2\right)$

This Epifanij altered to fit in with the personal tone of Stefan's emotional plea:

яко ты еси прибутапе убогум, помодник во блвго врьмя в печальх.

.nother in this category involved a shift in the tense of the verb, as when the Permian Church laments Stefan's death:

$$
\begin{aligned}
& \text { понете ждвх иже би кто со иноп поскорбвл, и }
\end{aligned}
$$

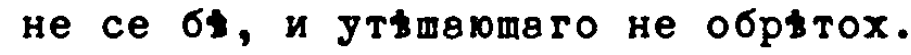

In the original this read:

$$
\text { (f. } 761 \text { from Ps. 69, x) }
$$

жьдах ине с мзною поскърбить и не бъ и јтьшаюших и не обрьтох.

In yet another instance, when Stefan is surrounded by Permians threatening him with bows and arrows, Epifanij omitted from an apposite quacation from Pr.91,x a phrase which does not refer to arrows. Compare:

$$
\text { не убоитися от стрли летящив в день, (f. 578) }
$$

from the Life with this from MS fp 1.2.:

не Јбоитися от страхв нощьнето и от стрылы льтяшая в дьни.

The second category of deliberate alteration of biblical texts is stylistic; Epifanij occasionally took liberties with them to fit trem into his word patterns. In the following example, he altered the second quotation to match the wording of the first. The context is Stefar's plea to God to deliver him from the clutches of the f'ermians:

Господи, что ся умножися стужвюшеи мны: мнози въсташа на мя, мнози борющеся с мною.

$$
\text { (f. } 673 \text { from Pss. 3, } i \text { and 129, viii) }
$$

The original read (in all variants):

\section{lihioraxgв брашвся с мною.}

lie also altered the verb in the first of a series of quotations ses in

a passa!ne in which the words usta, otvrésti and xvala in various :orms 
are woven into a typical example of pletenije sloves. In all variants of the original, the text reads?

$$
\text { рашири уста твоя и наполно } я \text {, }
$$

(MS fp 1.2 from Ps. 81, ix)

whereas in the Life it has been transformed:

$$
\begin{aligned}
& \text { другии пророк рече: "отверзи јств своя, и исполно } \\
& \text { я". Тьм хе отверау јств поя и наполнятся духом, } \\
& \text { и слово отригну и глаголю 8а: "Господи устны мои } \\
& \text { отверзнеши и Јста мог вззвыстят хвалу твор": } \\
& \text { " дв исполнятся уста моя похвал"", яко да } \\
& \text { восхвало славу твор и прилогу на всяку похвалу } \\
& \text { TBOD. }
\end{aligned}
$$

In a third example of deliberate alteration, Epifanij did not merely

reflace a word for stylistic reasons, but adapted a whole passage freely, basing it on the antithesis of the original but further emphasizing its negative qualities. Stefan condems the Permian idols as mere useless blocks of wood, and in a forceful rhythmically structured speech declares:

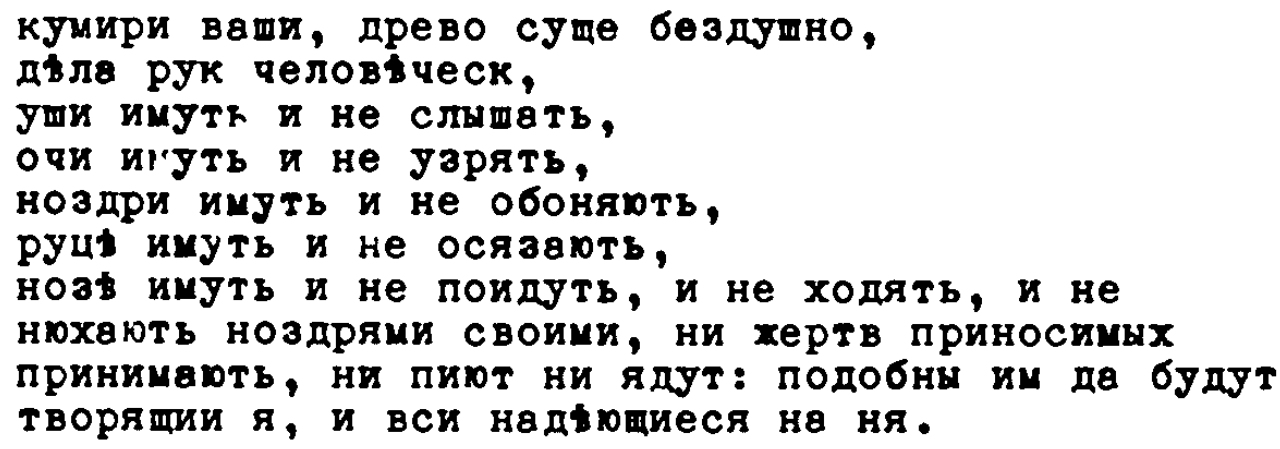

(1. 682 )

Th:s is an adaptation of Psalm 135, xv-xvii, which reads:

дыла рук человыческ, уста имуть и не поглаголоть, очи имуть и не прозьрять, уши имуть и не вънушать, ньств бо духв в Јстых их, подобни им да будјть творядии Я и вьси над\$рииися нв нь.

(MS Ip 1. 2) 35

It is thus evident that Epifanij not merely quoted from the Bible from

35. For an unadapted version of this quotation, see Evtimij's Bricomium to Ioan Polivockij, pp. 1912; and Nartyrdom of St. Vitus in Uspenskij sbornik XII-XIII vv., eds. O. A. Knjazevskaya, V. G. Dem'janov, M. V. Ljapon, M., 1971, f. $124 \mathrm{~g}, 11.18-22$. 
mewory, making frequent errors, but also adapted the wording to suit his purpose. In the interests of clarity he was obliged to alter some to fit into the context, but in the case of stylistic adaptations, he took a conscious decision to change the original for no reason other than that it suited his stylistic scheme. In view of traditional reverence for the Scriptures, this is a surprising conclusion, which casts light on Epifanij's ideas about the role of the hagiographer. But it is consonant with his exaggerated humility, his confessions of unworthiness and pleas for a tolerant reception of his work. 36 For, he conceived of the vita as a re-creation of the spiritual aura that surrounded the saint in his lifetime. A vita wast induce in the audience the awe felt by the author and (presumably) by those who knew him. It is a measure of Epifanij's consciousness of the hagiographer's duty that he allowed himself to adapt the Bible.

Several conclusions may be drawn. Firstly there is no evidence that Epifanij referred to biblical texts meant for private reading when selecting quotations for the life of Stefan. Nor did he refer to the Service Psalter when writing, because the quotations from the Psalter in the life differed far more radically from the original than separate copies of the Psalter differed from each other; if he had copied, one would expect mistakes to be no more serious than the differences between two copies of the Psalter. Since this was not the case, it was clear that he quoted from memory, and that his memory failed him occasionally. Confirmation was seen in the higher incidence of mistakes from parts of the Bible he would not have known so well. The impression gained from reading, that the author of the Life spontaneously poured forth his own feelings of awe and veneration, is thus confirmed. Epifanij did not compose laboriously; his word patterns are the product of a remarkable poetic talent. 
CHAPTER VI The role and runction of biblical quotations

Though Epifanij and perhaps all hagiographers did not check biblical quotations before using them, they valued the authority that scriptural quotations lent to their compositions. Mediaeval writers likened the collection of suitable quotatione to the bee gathering honey from a myriad of different flowers. Quotations were employed in vitae in two ways, illustratively and stylistically. Illustrative quotations backed up statements about hagiography or the subject of the vita, dewonstrating his affinity with biblical personages, and showing how his virtues and actions fulfilled the precepts and predictions of the Scriptures. When incorporated into the saint's speeches, they revealed his close ties with the written source of spiritual wisdom and hence with God. Stylistic quotations manipulated the audience's reactions to the situations described and evoked the 'correct' emotional response of awe and reverence. Biblical quotations appear with greater frequency in Epifanij's, Evtimij's and Domentian's vitae than is normal for Slavonic hagiography, though the incidence varies from one writer to the next. Stanojevic and Glumac's work on the origin of quotations in Serbian and some Bulgarian literature provides the basis for a simple statistical comparison. ${ }^{1}$ They furnish accurate figures for Vomentian's and Teodosije's vitae, together with a corrected figure for ivtimij's Life of loan of Rila. 2 Few editors of hagiographical texts have possessed the same knowledge and patience; DruZinin's edition of the life of Stefan traced the vast majority of the huge number of quotations but other editors were less thorough. 3 As a

1. St. Stanojević and $V$. Glumac, Sv. Pismo u našim starim spomenicima, Bel grade, 1932 .

2. They showed that there were nearly twice as many quotations in the Life of Ioan than Vranska suggested in Stilni poxvati, chap. ix.

3. See p. 119, n. 3, for examples of quotations omitted by Družinin. Some editors like Abramovic or Kauziacki only note biblical quotations preceded by an introductory phrase. For these works therefore, the figures on the chart are my own, and should be considered only rough approximations. 
result, the figures on the chart are only a rough guide. One nonhagiographical work, Ilarion's Sermen on Law and Grace is included fo: reasons of conparison and because Muller's excellent edition documents both biblical quotations and phraseology. 4

COMPARATIVE TARLE OF THE FREQUENCY OF BIBLICAL QUOTATIONS

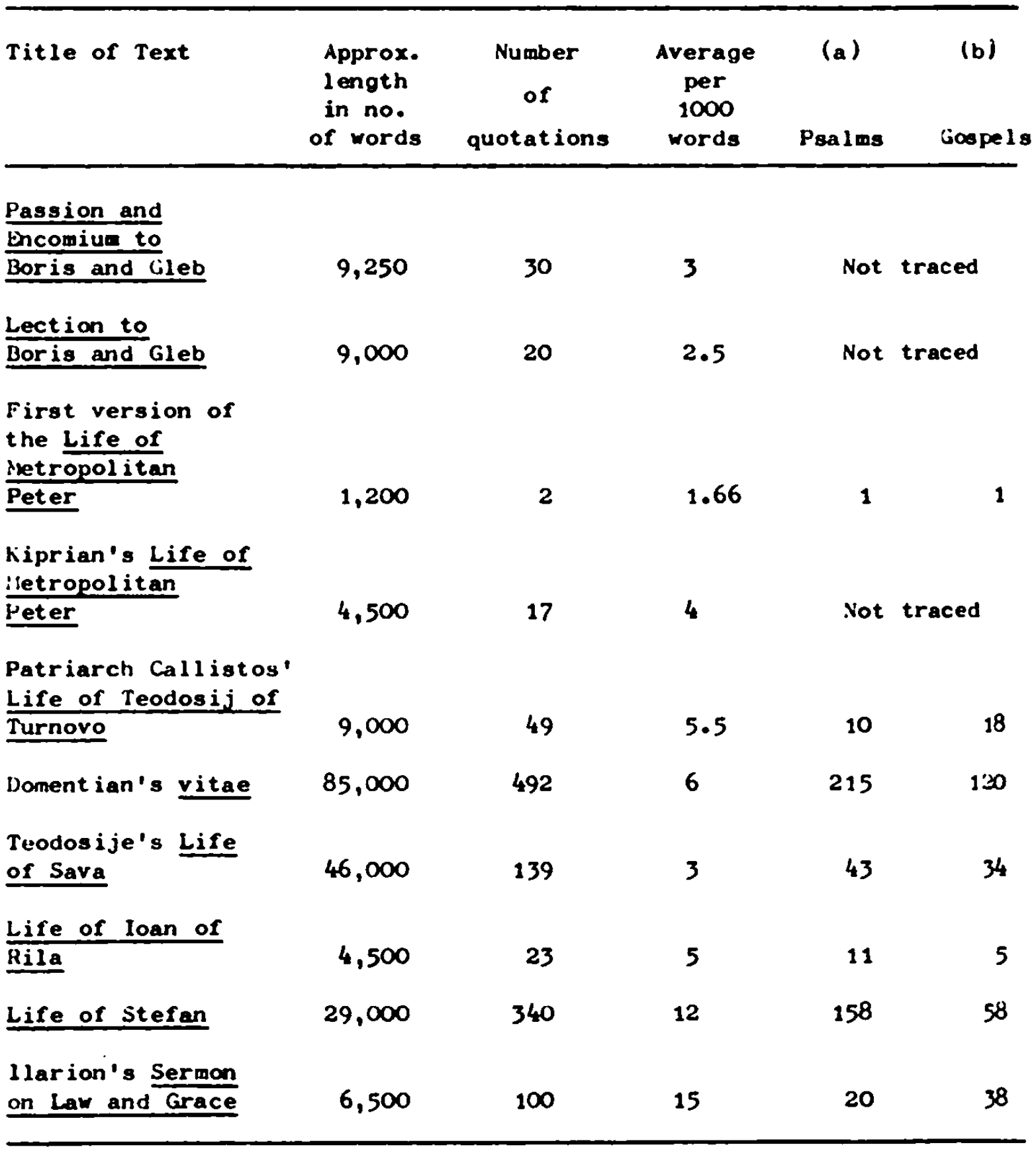

4. For full references to this and other texts analysed here, see the biuliography of primary sources. 
The extresely high incidence of quotations in Ilarion's sermon is to be explained partly by its genre and partly by its individual characteristics. Sermons are usually based, if not on a specific passage from the Bible, then on an aspect of Christian dogme cuotations which furnish the necessary proof for arouments put forward in the sermon, are more often drawn from the New Testament than the poetic books of the Old. Ilarion's sermon, apart from its didactic function, possesses clear polemic ains which required frequent reference to biblical sources. In the first part of the work, discussing the superiority of Grace over Law through the nedium of the story of Hagar and Sarah, he enploys few quotations. However the following section, which argues the superiority of Christianity over Judaism is composed almost entirely of carefully chosen New Testament quotations woven into an integrated whole. Then when he turns to a discussion of how Christianity spread throughout the world to reach even Rus', he produces a long string of poetic quotations from the Psalms underlining the point that the whole world will praise God. llarion's powers of logic are matched by his skill in selecting quotations not werely for their ability to underpin his argument, but also for emotional impact.

In Kievan hagiography, quotations are far less common; witness the relatively low incidence in Nestor's Lection. Illustrative quotations are scattered throughout the work, whereas stylistic quotations are restricted to those parts which demand emotional emphasis as in the dramatic accounts of the deaths of the two brothers. In the eulogy however, Nestor has recourse to other stylistic devices. In the Passion and Dncomiun, quotations are either employed illustratively or, in the meditations, prayers and speeches of the two brothers, to demonstrate their sanctity. In keeping with the overall tone of the work both types are of a 
predominantly lyrical character. That the Skazanije which does not conform to the prescriptions of the formal rhetorical vita should employ biblical quotations more than the Lection is an indication of the degree of personal choice that operated within hagiographical convention. In view of Kiprian's deep reverence for traditional ecclesiastical texts, the higher incidence of quotations in the Life of Peter need cause no surprise. 5 is an accomplished work of hagiographical rhetoric, the Life includes more quotations than the simple early life of Peter. ${ }^{6}$ The number of quotations tallies with those in the vitae of his mentor Evtimij, when it is remembered that the figure of four quotations per thousand words in the Life of Peter is probably too Iow, while that of five per thousand for the Life of loan of Rila is fairly accurate. Evtimij selects his quotations nearly as much to illustrate stages in his argument or narrative as to heighten emotional effect. Eut in his encomia, a genre which demanded a more poetic treatment, quotations from the poetic sections of the Old Testament are far more numerous than those from prose 13ooks. 7

Differences between Greek and Slavonic hagiography are revealed through comparison of Callistos' quotations in the Life of Teodosij

5. jee p. $1: 8$ supra.

6. For a discussion of the work and its author see V. A. Kučkin, 'Skazanije o smerti mitropolita Petra', TOUL, XVIII, M-L., 1962, pp. 59-30.

7. In fact according to Vranska's list of quotations (op. cit., pp. 149-56), there are more from the New Testament than the Old, but stanojević and Glumac's research on the Life of Iaan of Rila showed that there were numerous quotations from Psalms embedded in the text without attribution (op. cit., pp. 594-600). Their conclusion was that quotations from Psalms were more common than those from the Gospels, and that overall there were a roughly equal number of quotations from old and New Testaments. In this case, the proportion of poetic quotations in the encomia is undoubtedly even higher than Vranska's figures suggest. 
of Turnovo with Evtimij's in the life of loan. Both vitae are admirable examples of their genre, both display their authors' mastery of rhetoric, though neither possess the emotionalism of the life of Stefan. And yet their preferences for different Books are quite distinct; quotations from the Gospels are nearly twice as frequent as those from the Psalms in the Life of Teodosij; in the Life of laan, it is the other way round. Reasons may be sought in individual preference and educational background; Evtimij's ecclesiastical training led to the saturation of his language with phraseology from the Psalms, while the broader education of his friend Callistos led him to prefer other devices when he aimed at poetic effect. 8

A statistical guide to the number of quotations from poetic Books is nevertheless a fallible measure of the emotionalism of a vita, for according to the chart there are only three quotations per thousand words in Teodosije's Life of Sava of which thirty five per cent are from Psalms, and no more than six in Domentian's vitae (forty five.per cent from Psalms), though Serbian hagiography is noticeably more emotional and less inhibited by Byzantine rhetorical etiquette than Bulgarian. But several points should be made: firstly, though all these vitae are extremely long, the amount of biographical detail is no greater than in a Life of average length. Hence the number of points in the narrative requiring illustration is the same. Secondly, quotations in Serbian vitae tend to be exceptionally long in keeping with the diffuse style of the work as a whole. Thirdly, the correlation between lyrical tone and quotations from Hebrew poetry is maintained: Teodosije's drier style is matched by a preference for quotations from the Gospels; Domentian, whose staggering number of

8. Further evidence for this view may be seen in Callistos' imagery which is less obviously biblical in origin than that of his Slavonic counterparts (for example, the images of the magnet attracting iron and that of the honeybee). 
quotations is drawn from forty one different Books, reveals a predictable preference for Hebrew poetry especially the Psalms.

Lyrical style and quotations from Hebrew poetry are obviously connected, a fact confirmed by the extremely high proportion of quotations from Psalms in the Life of Stefan. Furtherwore, the Life contains twice as many quotations per thousand words as any other vita examined. This can not in itself render the work poetic, but it can and does betray the hagiographer's attitudes; here Epifanij's fear that his own work will not conform to his high ideals of hagiography, a fear that prompts him to seek constant support from the Scriptures. Furthermore, the stylistic application of quotations in the Life of Stefan is as significant as their incidence.

In essence, Epifanij's use of quotations falls into the traditional illustrative and stylistic categories. Topoi of the exordium and conclusion are illustrated and reinforced by quotations; thus Epifanij supports his reference to the source of his material:

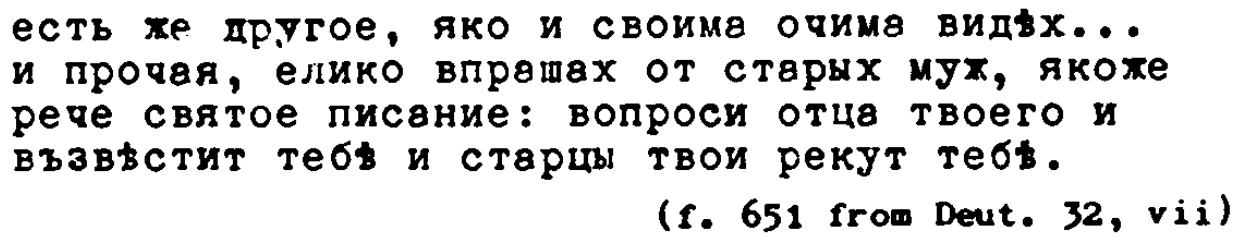

In this way, he adds force to a sentiment so cowmonplace that it risked losing all impact. Illustrative quotations also support any fact or stage in the narrative which can be turned to advantage. Thus Stefan's entry into a monastery is too ordinary an action to be worthy of special comment, whereas his piety and learning in the monastery mark him apart, and thus require the support of a quotation:

с рвзумными же гвдвние его быввше, и с премудрыми размышление его, и вся бесьды его в законь Господни биввху, якоте впостол Павел к Тимофех 
посылаше, глаголя:"чадо Тимофье, внимаи чтекио и јченио и ттышенио, выдыи от кого ся еси научил; яко святия книгм из млада умњеши, могушөв тя уиудрити о Христь Иисус\$"

$$
\text { (1. } 657 \text { v. from II Tile. 3, xiv-xr) }
$$

Stefan's virtues are seen as identical to those recomended to Timothy. jomet imes the message of the quotation is reinforced by stylistic means such as repetition of the key word as:

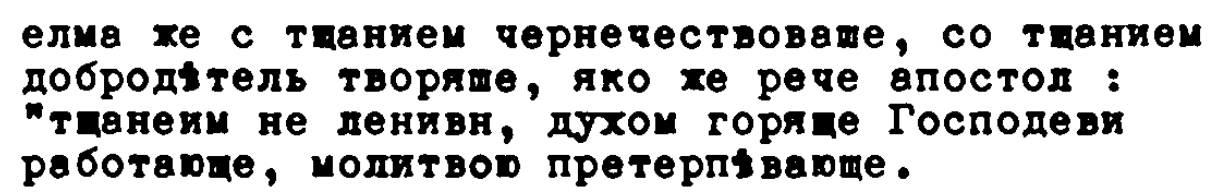

Illustrative quotations play a significant role in Stefan's monologues, speeches and horilies. As discussed earlier, Stefan's solitary meditations consist entirely of biblical quotations. 9 when he requests permission of his Bishop to depart for Perm', he uses his own words, heavily interlarded with quotations:

I shall lay down my life for Christ, the faith and true confession, as the apostle said, 'for unto us it is given not only to believe on him, but also to suffer for his sake'. ( 1 Phil. 1, xxix) 'Let us run with patience the race that is set before us, looking unto Jesus, the author and finisher of our laith.' (llebr. 12, i) Therefore, my lord, 'now lettest thou thy servant depart in peace, according to thy word' (Luke $2, x x i x$ ) and pray for me...

The function of the three quotations is not identical: the first two justify the mission, but the third underlines Stefan's saintliness.

In Stefan's homilies, quotations furnish the necessary backing to his explanation of Christian belief. These are the only sections of the Life where mippets from the New Testament outnumber those from the Old. Even so, Epifanij reveals a stronger preference for emotive parts of the New Testament than either Ilarion in the Sermon on Law and Grace or Evtiaij in the Life of Ilarion of Maglen. In the same way, Stefan's 
quotations in the debate illustrate statements rather than prove points as in the Life of Ilarion. The inclusion of quotations, especially those of a poetic tenor was intended to gain the sympathies of Epifanij's audience. 10

Though illustrative quotations in the Life are both numerous and varied, stylistic quotations take precedence by virtue of number and originality. Urawn predominantly from Hebrew poetry, stylistic quotations are often concentrated into groups where one werges subtly with another. In this way, Epifanij achieves a poetic intensity rivalled only in the most lyrical sections of the duthor's Lament. As a general rule, all three laments rely on Epifanij's pletenije sloves rather than poetic quotations. The one exception is the Lament of the Permian Church, where the latter part describing the Church's search for solace in God consists almost entirely of quotations brilliantly interwoven to ensure that the Lament concludes on a note of lyrical optimism. 11 The following extract marks the transition from grief (in the first three quotations) to the theme of comfort, and exemplifies Epifanij's skilful combination of quotations without a single linking phrase except for the poignant 'since I am in Perı'" which adds a note of immediacy:

к немуле и аз молитву си пролию к Господу, "и тому възвьшу печвль мою, яко Јтрудихся воздыхвнием моим",/Пс. $6, \overline{V I} /$ "и исчезе сердце мое и плоть моя", Мс. 73,XXУ/ "и исчезошв яко дым дние мои, и кости моя яко сушило исхота, и яко трава исше сердие мое", Mc. IO2, ІУ-J/"и аз яко сзно исхох", /Пс.IO2, XI/, "но в печвли моев призвах Господа, и јслиша мя в пространствь", Пс.II8, помянух бо судбы его от выка и утышихся" : /Пв. II9, LII/, мн те прильплятися к Богу благо есть, и полагати на Господа улование спасенив моего". /Mc. 73, XXYIII/ "К нему усти моими возвах", Mc. 67, ХУІІ/ впе и в Перии сущев ми, "в земли пуств, нрпроходн и безводнs": /Пс. 63 , I/ Господн sо есть земля и коним", Mc. $24, \mathrm{I} /$ "Господь есть упование всым кондем земли и суше в мори далече": /Пс. $65,9 /$ "но обаче и тамо сего ради услыта ия Бог и внят глас молитвы моея"./. $66, \%$ 
The passage ends in a climax of lyrical and rhythmic repetition:

Бот всякого утшение, Јтtтав нас на всяк уас jтышентек святого своего дуга, вминь. (1. 761)

It is more unusual to find strings of biblical quotations in the central narrative section of the Life, where they deflect attention from the course of events. But this is consonant with the contrast between vivid narrative and the timeless sionificance of events, which is the hallmark of the Life of Stefan. Epifanij twice emphasizes that Stefan's survival anidst hostile pagans was due to God's protection of the righteous, ${ }^{12}$ in one instance adding twelve quotations to prove his point. ${ }^{13}$ In the dramatic scene in which the shaman attempts to seduce the new converts away from Christianity, Epifanij explains the significance of Stefan's new enemy by comparing him to sorcerers in the New Testament and quoting 01d Testament prophecies of the downfall of the wicked. ${ }^{14}$ In this way the shaman becomes a symbol of eternal evil. Most startling of all is Epifanij's use of quotations in his justification of the missionary calling in the chapter entitled $O$ prizvanii, $i$ o verovanii mogyx jazyk', a long eulogy of Stefan's achievements. ${ }^{15}$ The chapter opens with a string of sixty five quotations, drawn almost entirely from Psalms and showing how the glory and praise of God shall surely reach the ends of the earth. The panegyric tone and constant repetition of the theme have the emotional effect of a hym or prayer.

To be able to combine familiar snippets from the Bible in a manner that preserves the impact of the original while overall lending them a

\footnotetext{
12. If. 681 v. and 692 .

13. f. $692 \mathrm{v}$.

14. ff. 698-699.

15. If. 722 v. -725 v.
} 
fresh weaning indicates an extraordinary literary talent. It is not shared by other hagiographers writing in pletenije sloves. Evtimij forms chains of quotations in only two situations; firstly, in the debates in the Life of Ilarion, where they are essential support for Ilarion's arguments against heretics, and do not serve any stylistic function. jecondly, in the concluding eulogies (or in his encomia), clusters of up to four quotations serve to raise the emotional tone. Thus the best examples of groups of quotations in his vitae are in the most ornate passages, such as the conclusion of the Life of l'etka. 16 Teodosije on the other hand, never links more than two together, though individual quotations are up to five verses long, a rare phenomenon in the Life of Stefan of Perm', where the only similar examples are of deliberately amplified passages such as the enumeration of the virtues of the ideal bishop, amalgamated from two New Testament quotations, 17 or in the rhythmic description of the Permian idols. 18 Domentian shares Teodosije's liking for long quotations, but like Epifanij weaves strings of four together occasionally. 19 They are also drawn from l'salms and possess a stylistic function. It is thus clear that chains of biblical quotations are a feature of hagiography composed in pletenije sloves, particularly of the Life of jtefan.

Epifanij also alters long scriptural passages to $f$ it the context of his work. In the opening pages of the account of the mission, he subtly adapts the parable of the hired labourers to apply to the conversion of the Permians. 20 The first six verses are retold almost in the words of

16. p. 76 .

17. f. 717 v. from I Tim. 3, $i i-i i i$ and Tit. 1, vii-xi. See Konovalova, 'Izobrazitel'nyje i emocional'nyje funkcii', p. 326.

13. f. 682 discussed on p. 136.

19. For example in the Life of Simeon, p. 8, 11. 13-18.

20. f. 663 v. - f. 664 v. from liatt. 20, i-xvi. 
Such linguistic virtuosity is unrivalled anywere in the ecclesiastical literature of the Orthodox Slavs.

Nor can Epifanij's distinctive use of long strings of quotations be equalled in hagiography. The only parallel is in the Sermon on Law and Grace, which contains a long chain of quotations fron Psales similar to those in the Life. It is possible that Epifanij was influenced by Ilarion's sermon, but though borrowing from other ecclesiastical genres was a comon process, it rarely extended to stylistic method. ${ }^{23}$ strings of quotations be seen simply as a natural development in Epifanij's pletenije sloves.

Apart frow using quotations in new ways, Epifanij differs frow other hagiographers in employing them largely for stylistic reasons to strengthen the impact of the work as a whole or of a point in particular. He alone uses thew to realise his concept of sanctity by bringing out the significance of the mission and drawing the audience's attention away from the realistic tale of Stefan's ordeals. Only hagiographers like Epifanij, Dowentian and the anonymous author of the Passion and Pncomium to Boris and Gleb, who are concerned about the emotional impact of their work, employ predominantly poetic quotations. So, for all the similarities between the writers of pletenije sloves in their intensified use of biblical quotations, ultimately individual differences are more important. But even a predilection for quotations would not make Epifanij's use of them so effective: the careful choice of apt passages and their concentration and varied application reveal his literary talent as well as reflecting his striving for greater expressiveness.

23. The famous passage from Ilarion which praises the apostles of many lands was imensely popular in early Russian literature, (see A. B. Nikol'skaja, 'Slovo mitropolita llariona $v$ pozdnejłej literaturnoj tradicij', Slavia, VII, Prague, 1928, pp. 549-63 and $853-70)$. 


\section{CHAPTES VII Symbol and historical parallel}

In the Middle Ages religious sybolism constituted a system deriving ultimately from the prophetic Books of the old Testament. The waaning of Inrael's existence and her relationahip with God for exarple, was elucidated through the inage of the Vine. 1 This and other inage underwent further developent in the New Testament and the reaulting arsenal furnished the weapons for explaining abstract religious concepts in simle term. Nurtherwore the whole mothod of interpretation by symols proved extrewely congenial to the prevailing cast of aind, and roo early Christian tiwes was extended to include all worldly phenomena (seen as sybols of the eternal), the Old Testament (as a symbol of the New), numals, and religious ceremony and ritual. 2 In literature, the combination of a love of symolism and tradition was reflected in inagery. By contrast with wodern witers wo strive for novelty through the apt and unexpected linking of two objects not obviously possessing anything in comson, the modiaeval witer saw his images as the more successful for drawing on traditional symbolic associations. It is not the external appearance of the object used for comparison that is of interest, but rather its waning in religious tradition. So the deer races to the stream not to slake its thirst, but to furnish an example of the love of God. 3

For all its conservatism, mediaeval symbolic imagery did evolve gradually in the various countries of Christian Durope. In Russia, as Adrianova

1. The interpreter's dictionary of the Bible, 4 rols., N.Y., 1962, III, entry under 'aybol'. See also Lixacev, Poetika, Pp. 62-158

2. E. Kale, The Gothic Image, London, 1961, pp. 14-22. What Male has to ay about thirteenth century French art is relevant in ganeral, if not in particular to mediaeval Russien literature: see, for example, the exposition of the symbol of the monk's habit in ane of Kirill of Turov's sermons (TODL, XI, M-L., 1955, p. 358) and Lixacer, Pootika, p. 160 , n. 10 .

3. Nie, op. cit., p. 161; Lixačer, l'oetika, pp. $168-85$. 
l'eretc showed, writers of 'high-style' ecclesiastical literature were influenced by their acquaintanceship with the native folk tradition in their selection of imanes. 4 inalysing the types of 'metaphor-symbol' in iussian literature from the eleventh to seventeenth centuries, she showed how ecclesiastical writers draw their images almost entirely from the Christian heritage. However the broad scope of her book prevented her from examining individual approaches to this tradition. Her request for more detailed studies was met by honovalova who made a classification of the types of imagery in the Life of Stefan of Perm' and analysed some in detail.j honovalova does not, however, draw sufficient comparison with other writers to place Epifanij within his Russian context or show clearly the niture of his originality. Nor does she discuss the device of comparison with biblical and historical characters and events.

In hievan hagiography, symbolic images are brief and traditional: in liestor's Lection for example, they arc neither so common nor so long as in the Life. Boris and Gleb are likened to innocent lambs, a standard Christian image. 6 Military imagos in the Lection, mostly found in yuotations taken from the salter, may have helped the formation of the iconographic tradition of depicting the two brothers in the guist of warriors. A number of other common symbolic imiges are to be found, only one of which is amplified. This predictably, is to be found in the lyrical eulogy concluding the work, where Nestor expands the conventional comilirison between saint and star or sun:

4. Očerki, p. 11; see also loetika, p. 161.

5. 'Sravnenije kak literaturnyj prijem'.

6. For example Jer. II, xix; Matt. 10, xvi.

7. Konovalova, 'Sravnenije kak literaturnyj prijen', p. 132. 
лехашаи бо в тебз есть свттль неугасаищи солнце

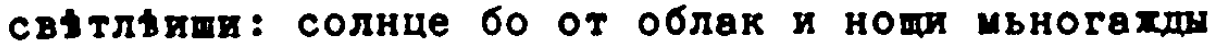
покрывается, свьтиль те блатенор, нощь и день

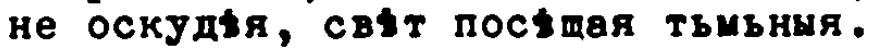

(p. 26)

The source of this poetic eabroidery of images is probably religious poetry; Kirill of Turov's prayers, constructed along traditional lines, display a similar love of syabolic imagery. ${ }^{8}$ le expands the same image as Nestor:

яко первде свутлости пртсветдо предстоящ, свьтпда отнеобравная, во мрах соблахненил обтогаема, молитвами вашими озарите мя, яко свцтила трпсолнечна богосияняя суще принмалнпа пребогатая. (p. 246)

Although symbolic imagery is not extensively employed in Kievan hagiography, it is prominent in sermons, which as a medium for the propagation of Christian teaching relied heavily on symbols. Difficult concepts could be elucidated by a felicitous choice of symbol. Thus the first part of Ilarion's sermon presents the superiority of Grace over Law through the symbols of Hagar and Sarah. Pursuing the story in Genesis to its conclusion, Ilarion interprets it as an allegory of the coming of Grace through Christ. When he comes to describe the spread of Christianity to Russia, he makes much of the traditional image of flowing water. The image of water is one of the most varied in the Sermon; phrases such as rosy blagodatnyja or dožd' blagodatnyj indicate its flexibility. 9 One of Ilarion's most successful images is the picture of the sun dispelling

8. Nmong the images in Kirill's prayers are those of the flowers of the field (Gebete, p. 328), spiritual sickness/doctor (pp. 308, 325, 343), the sea of life (pp. 251, 327), the barren fig tree (p. 274), the warrior of Christ (p. 284), the spider's web (pp. 257, 319), cattle (pp. 246, 258, 314, 235), 1ight and darkness (pp. 235 and many other places).

9. pp. $20,29$. 
the cold light of the mon, in wich each detail undergoes separate interpretation. 10 This type of elaborate sybol is characterietic of Kirill of Turov's sermans wich rely nearly as wach on allegory as his parables. Kirill's famous sermon for the week after Enster contains an elaborate syabolic picture of spring. ${ }^{11}$

Epifanij's restless search for greater expressiveness led hil to reach out beyond the traditional stylistic bounds of the rite. It would be surprising if this vere not also true of imagery, and equally so if his borrowings were not more daring than Dowentian's or Ertimij's. Naturally all three drew on the same stock of inherited images, modified by their respective cultural traditions. Set in this framework, exceptions stand out clearly. Thus Epifanij employs one simile thet appears entirely his om, drawn from everyday life, a rare occurrence in hagiography. In the Author's Lawent he considers how best to glorify Stefan: 'shall I call you preacher, for like a tom crier crying in the arket place, you declained the word of God among peoples $2^{12}$ The sindle strikes modern ears as inappropriate, but Epifanij is not comparing Stefan with the town crier himself, only with his bold manner of proclaiming the ners. Nevertheless the image possesses a startling originality in the context of mediaeval traditions of biblical imagery. Lixačev regards the search for an expressive etyle at this pariod as the beginning of the breakdown of modiaeval symolise, suggeet ing that 'new images are formed on the basis of observation, of actual sinilarity.... 13 However the town crier

10. p. 27 .

11. 'Slovo $v$ noruju nedelju po pasce', TODL, XXI, M-L., 1956, pp. 340-7. See infra p. $176 \mathrm{ff}$. for a detailed comparison between Kirill': and Epifanij's sybolic pictures.

12. p. 766 .

13. Poet ika, p. 166. 
is the only totally new image in the Life of Stefan, a work which Lixačev considers to be in the forefront of this development. It is much more credible that this, like Epifanij's references to Stefan's nickname, is an artistic lapse.

Other images in the Life that at first sight appear original are all founded in biblical tradition even if employed by Epifanij in an unusual manner. The conventional sybol of the deer thirsting for water, representing the righteous man thirsting after knowledge of God, is to be found in any vitae; both Evtimij and Domentian employ it with this meaning. $^{14}$ The comparison is an abstract one; ${ }^{15}$ no image of a deer is actually evoked, the parallel being dram between a virtue seen in isolation from the personality as a whole and a symbol of spiritual thirst. In the Life of Stefan Epifanij says of the humiliated shaman; 'he leapt away from them like a deer, and went away from the assembled people'. 16 Here the symbol of the deer is adapted to the less abstract concept of fleetness of foot. It is 1 ess remote than the Christian symbol because ultimately based on observation of the real world, and probably sprang from Hussian folk imagery. It is unlikely that Epifanij invented this symbol, but possible that he was not aware of his departure from hagiographic convention.

In another instance however, it is harder to attribute his adaptation of a conventional symbol to folk imagery. The cobweb traditionally repre-

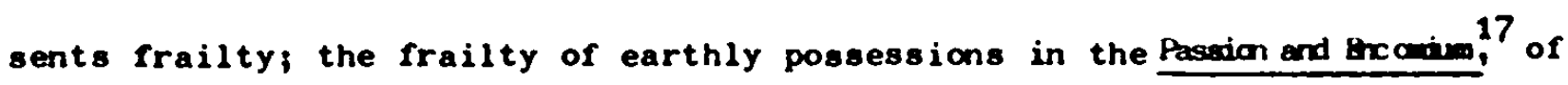

14. Life of Sava, p. .134; Life of Petka, p. 70; Life of loan, p. 17 quoted by Vranska, op. cit., p. 164. I. I. Sremevskij, Materialy dlja s lovarja drevnerusskogo jazyka, 4 vols., St.P., 1895-1912, cites an instance of this image in the Greek Life of Agafij (VMX for February) in his entry under elen'.

15. Lixą̌ev, 'Izobraženije Ijudej', p. 111.

16. 1.715 .

17. P. 30 . 
human nature or human truths in Kirill of Rurov's prayers, ${ }^{18}$ the snares of heretics in the Life of Ilarion of Molen. ${ }^{19}$ In the Life of Stefan on the other hand, it is Epifanij's literary work that is compared to the spinning of a spider's web. The passage is composed in a complex style that underlines his point:

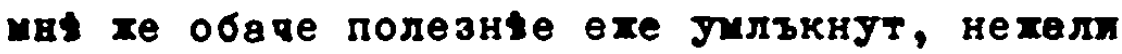 паучноточная простирати прядение, вки нита мызиревих тенет путати.}

$(8.776 \mathrm{r.})$

The adaptation of the passage is not only original but apt; the intricate but ordered patterns of pletenije sloves resemble the shimering, delicate spider's web. While retaining the idea of frailty, Epifanij succeeds in suggesting both his manner of writing and the fear that his audience may be trapped in the web of words with which he has tried (and failed?) to portray sanctity.

One further image is sometimes regarded as original; the picture of 'beautiful feet' in the passage describing Stefan's departure for Perm':

$$
\begin{aligned}
& \text { поиде в землю, идыхе не ходиша ногама сии святии } \\
& \text { апостоли, учекиц Господни. По истинь бо т\$х суть } \\
& \text { крвсны ногы, благоввствуюших мир. }
\end{aligned}
$$

is Konovalova rightly points out, the links with going on foot are almost entirely broken; it is the action of the preacher going out to enlighten a heathen people that is beautiful. 20 Eertainly this furnishes a good example of the abstract nature of the imanery in the Life, ${ }^{21}$ but it is erroneous to see it as a reflection of Epifanij's dislike of the straightjacket of tradition. Evtimij employs exactly the same image, ${ }^{22}$ which is

13. pp. $257,319$.

19. p. 33. For other examples from ecclesiastical literature, see ireznevskij, Materialy, s.v. pautina.

20. op. cit., p. 135 .

21. uncomium to Constantine and Helena, p. 129.

22. This also negates Lixačev's point (Poetika, p. 164), that it illustrates the transfer of the spiritual aspect of the journey to the physical feet that made it. 
drawn from Romans 10, xv:

and how shall they preach, except they be sent? As it is written, How beautiful are the feet of them that preach the gospel of peace and bring glad tidings of good things

with the exception of the few examples above, all the imagery in the Life is bound up with ecclesiastical symbolisa. Certain of these traditional images are so closely woven into the fabric of mediaeval literature that they become, to all intents and purposes, leitmotifs. Such is the fate of the image of the sheep and shepherd, which featured prominently in both $01 d$ and New Testaments. 23 The image of Christ, the Good Shepherd, guarding the flock of the faithful, received widespread application in both Byzantine and Slavonic literatures, such that any spiritual leader wight be termed shepherd and those he cared for sheep, though the symbol was often made clearer through the use of the interpretive adjective slovesnyje in slovesnyje ovcy. ${ }^{24}$ Evtimij and particularly Domentian employ it frequently; in the Life of Sava the Serbian people are termed flock and the leader, Sava, their shepherd. It is equally common in the Life of Stefan, where the subject-matter was peculiarly suited both to the sheep/shepherd group of images and that. of the sheep among wolves. Thus Stefan is at times the sheep of righteousness amidst the wolves of evil and at others the shepherd guarding his flock of spiritual sheep. This inconsistency was not apparent to Epifanij because the real associations of the image had been effaced. Indeed he even mixes metaphors in a maner highly reprehensible by modern stylistic criteria:

23. See Ezek., 24, viii; Jer., 23, i-ii; Ps. 23 with its references to baptisu contained in the image of the shepherd leading the sheep to quiet waters, and the two famous New Testament parables, that of the lost sheep, Matt. 18, xi 10, $i-x v i$ and Acts $20, x i x$.

24. Adrianova-Peretc, op. cit., p. 97 fr. 
и тако помоляся БогУ, и по молитвь дервповение наполнися, в ревнуя по Господь Вседергтен, дерзав по врь и по благочести побарая, ревностио бохественор рахтегся, крыпко препоясав чресга Своя, дрззнУР, вниде в ня, яко Овца посредь волк, и начвт учита я О Бозь и выр\$ крестианьстьн...

such combinations occur inevitably in a literature where imagery is based on symbolic associations rather than real similarities. 25

Konovalova noted that Epifanij uses the simile as a sheep among wolves' as it stands, whereas Evtimij adds a few details to it, 'as an innocent lamb amidst the wolves of wickedness', when referring to Ilarion's confrontation with heretics. 26 She argues that Evtimij places the image in a context that makes it clear, thereby rendering a hackneyed expression more concrete. 27 But the setting of the quotation from the Life of Stefan is no less comprehensible, nor do Evtimij's additions make his image more concrete. All he does is to add the conventional symbolic interpretation to elucidate his comparison, though this was hardly necessary in view of its familiarity. Evtimij's image is no less abstract than Epifanij's though he does not in this instance mix his metaphors. 28

The two writers do differ in their treatment of these common symbolic images, as Konovalova suggests. Evtimij comonly adds a word or two of

25. Lonovalova, 'Jramenije kak literaturnyj prijem', p. 135, discusses this image in detail.

26. Life of Ilarion, p. 32 .

27. Konovalova, 'Sramenije kak literaturnyj prijem', p. 124. The addition of words of explanation is very common. Ilarion for example also refers to the innocent lamb (Sermon on Law and Grace, p. 96).

28. See Life of Petka, p. 73 or Life of Ilarion, p. 31 for examples of mixed metaphors. Both are contained within passages of oulogy, cf Life of Sava, pp. 168-9. Domentian however, like Epifanij, mixes metaphors at other times (witness the confusion of the images of deer and eagle on p. 139 of the Life of Sava). Such mixtures may have offended Evtimij's rhetorical training. 
elucidation, whereas Epifanij generally either leaves the image in the form found in the Bible, or eabroiders a mass of detail around it, as:

дв что тя приглапу, пастуха ли нареку, понехе пасл еси христово стадо хрестианьское словесних овець, на злац ралјиици, тезлом словес твоих, в паствин јченте твоето и нин паствь пастух can пасои бивает в тапвом алан,

(1. 767 )

or in the Lament of the Permian Church:

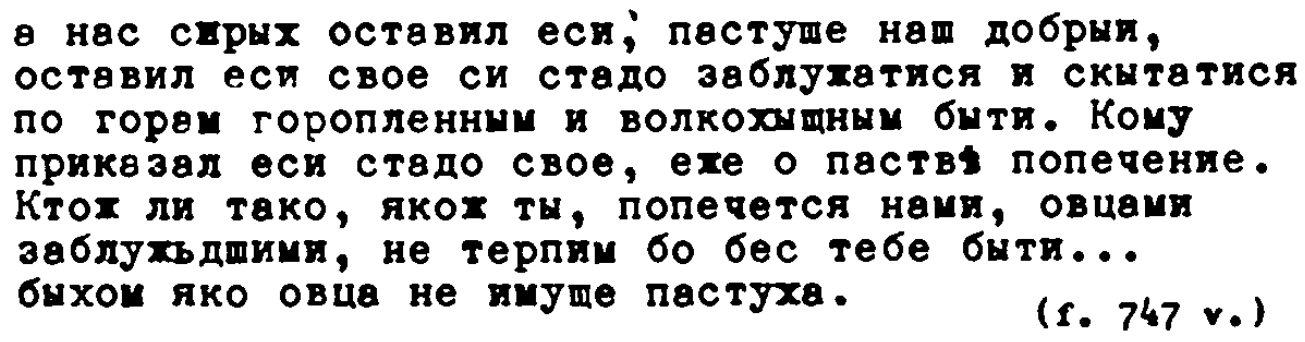

It is interesting to note that in the second passage the conventional desire to create a purely symbolic picture is dimmed. Epifanij wishes to affect his audience with a touching picture of the Permians as sheep, lost and neglected after the death of their shepherd Stefan, and though the basic idea is present in the bible, its poetic elaboration is characteristic of Epifanij's pletenije sloves. The first passage demonstrates clearly the mediaeval tendency to interpret everything in a symbolic light. Most of the images can be found in P'salm 23, but the Psalmist makes no attempt to fit every single detail into an allegorical framework. By the Middle Ages each detail might receive individual interpretation. Nevertheless whole symbolic pictures are not a feature of Slavonic hagiography before Epifanij: even Evtimij only combines images in a non-pictorial fashion:

небо оубо того нарича, нако небесна проповьдв твинства: слъние - осіввветь бо чрдесн такохе

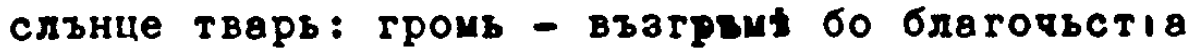
догиати Сз взстить дрзановеніемз: мльніх Освьти бо нако ильнів словесу догматскМми въСА земль: облакз - юко облак бо остнд взргченка ceбt паствх и капльия благодытними т\$x орос⿰ 
срздиа: ковчетз - взса бо добродытылі вз ceбе сзбра: скровиде - больстзвная бо таинства вз немь сзкрзвенв биша: чаго - бохвствнато бо вьстиь оуषенів подаств пиво и руषншии строуюами оучптелствв словесу взавесели вьрних доуш:

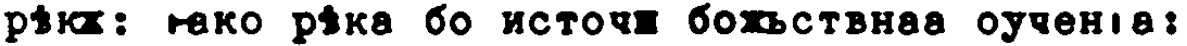
стльпз - прэмдрость бо того сзздв себs стлзп.

$$
\text { (Deconiue to loan Polirockij, pp. 200-1) } 29
$$

Alternatively he may paint a simple picture in sufficient clarity of detail to convey a vivid impression, without attaching a symbolic importance to each detail, as here:

reкохе бо слзицоу, вь прольтине чвси лоуче

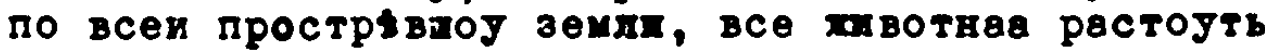

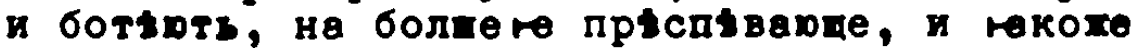
обновлген водеть сьборь, тако д долтовна повьсть веселіа водпть сьборь послолшартив доушамь и печалеи облакь вьсь оудобнь развьванеть и отгонить.

$$
\text { (Life of Petke, p. 60) }
$$

Domentian as in many other aspects of style is closer to Epifanij

than to Evtimij, preferring the allegorical picture:

$$
\begin{aligned}
& \text { сьблодыте добрь ствда богомь пүздвн вамь, } \\
& \text { и доухомь светиим неоусьпьно правите вьсе } \\
& \text { чловнкн...и пөсьте доуше ихь юөко добри пастшрию, } \\
& \text { подобеште се великопоу пвстироу доушелюовномоу, юко } \\
& \text { да посльдоутетв стопамь здравиихь овьць...пасьте } \\
& \text { же жъзлонь крьстьниим и пвлицер благодтти доуховь- }
\end{aligned}
$$

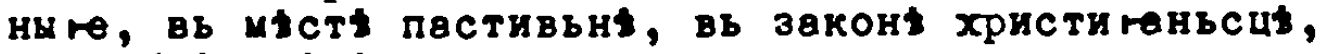

$$
\begin{aligned}
& \text { вь добрьи вырь питахте, напа raште не водами } \\
& \text { благовьри оть источьникь тввнгельскиихв. } \\
& \text { (Life of Sava, p. 287) }
\end{aligned}
$$

It should be noted that all three hagiographers in these examples of elaboration of standard symbols add a few words of interpretation. Konovalova is thus wrong in suggesting that this is a feature peculiar to Evtimij, though certainly Epifanij is prone to leave short familiar metaphors without explanation. 30

29. woted by Vranska, op. cit., p. 59. Combined symbolic images of this type are a feature of prayers. See for example, Kirill of Turov's prayers, iebete, p. 290.

30. 'Sravnenije kak literaturnyj prijem', p. 124. 
Of course, what has been said above about the sheep/shopherd eyobol may be artended to other comon lages in the works of the three writers. One found in various forms in the ritae of all three is that of the vine. A comson sybol in the Bible, and popular in carly Pussian literature, the vine stood for a Church. 31 Dpifanij coploye it a mubar of tines to describe the Permian Curch and calls Stefan delatel' vinorrada xistova. 32 On the other hand Brtinij does not eaploy it at all, and Dowentian only ance in the whole of the life of Sava. Since both writers vere wre familiar with vineyards than a Russian like Bpifanij, this furnishes additional proof that witers were unaware of the concrete association of images. Evtinij prefers the related biblical ajmbol for the righteous an of the tree planted by the waters of Christ's teaching and bearing the fruits of virtue. 33 Epifanij eaploys the same symol, anplifying it:

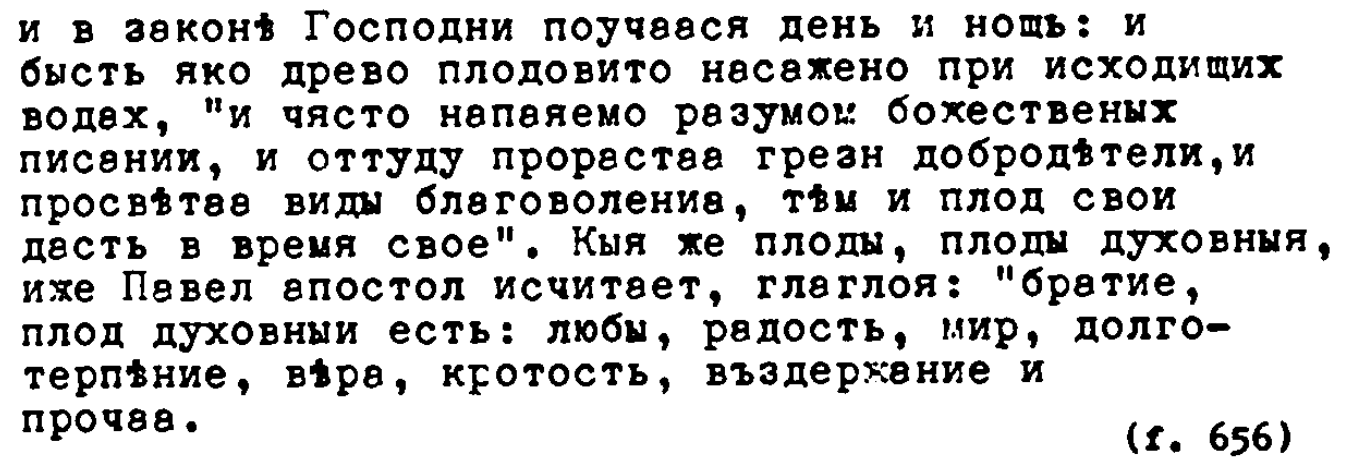

Related inages were often cosbined in early Slavonic literatures. Thus Drtinij says:

31. supra, p. 143; also Adrianova-Peretc, op. cit., p. 71.

32. 5.770 .

33. Ps. 1, iii and hebr. 12, $x i$ and other references. For an example in Drtimij's vitae, see the Life of Ilarion, p. 53.

34. The final quotation is from Gal. 5, xxii, but weh of the rest is based on Pa. 1, ili. See also Konovalova, 'Sravnenije', pp. $125-8$. 
...в творА плодь, по истинномоу сторичнии, накохе дрьво, насахденно при источникох водншх.

$$
\text { (Life of loan, p. 8) }
$$

thereby bringing together the image of the tree and those from the parable of the sower. 35 Such instances are less common in Domentian's vitae; references to the fruitful olive, the thorns of heresy, the cedars of Lebanon and others are normally kept apart. Epifanij however, counbines various biblical images into pictures in which it is difficult to distinguish the varied origins of its constituent partss

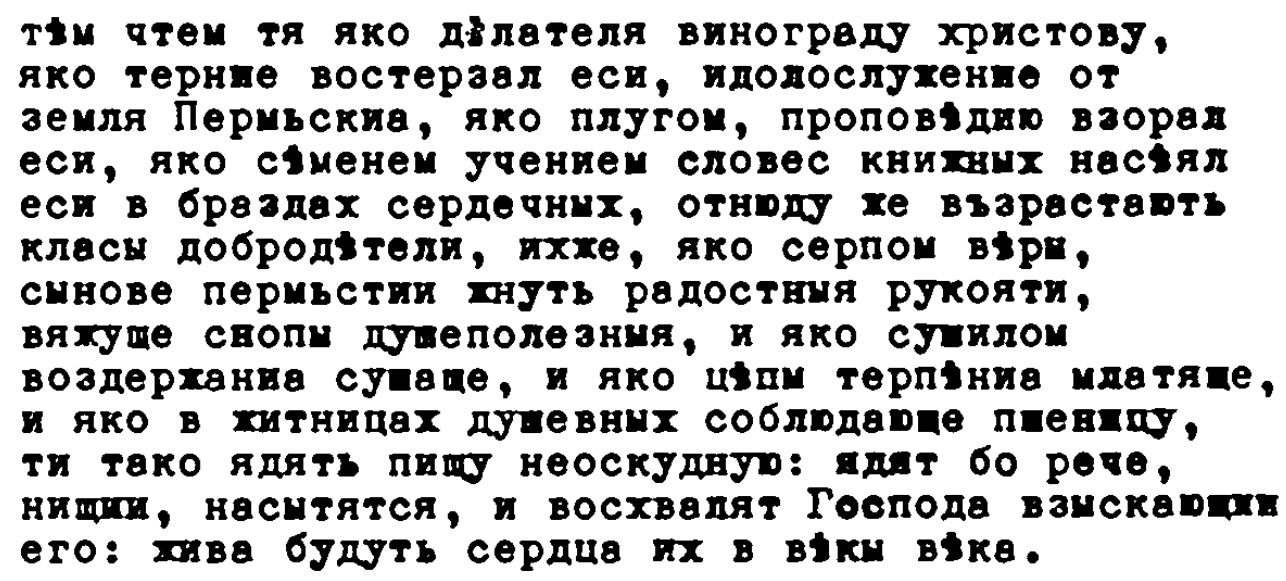

(If. 751 v. -752. The quotation is from Ps. 22, Ix

The details of this picture owe a debt to earlier models, probably Kievan, but some details are supplied by Epifanij's own fertile imagination. 36 The symbolic picture is an attempt to add forcefulness to the traditional comparison between spreading the word of the gospel and sowing. As such, it displays an extension of conventional symbolism.

Of particular interest is Epifanij's treatment of the biblical imge of the barren fig tree, in which he compares himself to the tree that bears

35. Matt. 13, viii.

36. Adrianova-Peretc, op. cit., pp. 60-70. Evtimij employs phrases found in Kievan literature such as dušnnyje brazdy i klasy dobrodêtělnyje (Life of Ioan, p. 13), wich suggests that they are Byzantine in origin. Epifanij however, is perhaps more likely to have dram them from familiar Kievan literary works. 
no fruit (only listy knižnyje), and consequently will be chopped dom by the axe that 1 ies ready at its foot, and cast into the fire. 37 All the details of this expressive word picture owe their origin to the Bible, with the exception of the 'bookish leaves', the focal point. Thus Epifanij subtly alters the symbolic interpretation of the image, rendering it more relevant to the context of denigration of his literary talent. 38 But the dominant symbolic leitmotif in the life is the traditional antithesis between darkness and light. 39 Though usually employed conventionally, it too is occasionally subject to greater amplification than in Domentian's and Evtimij's vitae. Both Evtimij and Domentian play down the antithesis, preferring conventional undeveloped variations on the symbol of 1 ight as epithets for the saint. 40 Epifanij on the other hand, brings the persistent theme of darkness and 1 ight to a climax in a lengthy description of stefan as svĕtil'nik (a candle or lamp), in which a detailed picture is replaced by paronomasia and biblical quotations. 41 No less than fourteen repetitions of the root svět, culminating in the phrase osvětil'niku světlo osvěščenu, create a strong persuasive rhythm. In this way ipifanij shows that he is capable of varying his method of strengthening traditional symbolic imagery.

The significance of comparisons between the words of the bishop who blesses jtefan on his departure for lerm' and precious stones was discussed

37. f. 775 v. from Luke 13, vi-ix.

38. See also Konovalova, op. cit., p. 129. I parallel process to his treatment of the parable of the hired labourers. See pp. 140-1 supra.

39. For a more detailed discussion of this and other antitheses in the works of all three hagiographers see pt. II, chap. iv supra.

40. Vranska, op. cit., pp. 57-9; Life of java, pp. 334, 132 etc. 41. r. 773 . 
in detail by Konovalova. 42 She showed that Epifanij was aware of the mediaeval symbolic interpretation of precious stones as Christian virtues. Apart from a comparison with the refining of gold in a furnace, Evtimij and Domentian make scant use of this group of syobols; Evtimij likens loan's firm purpose to adamant, 43 Domentian describes Sava as 'a holy treasure of a priceless pearl', 44 but on the whole prefers the general image of the treasure, one which appears only once in the life of Stafan. All three hagiographers employ the inge of rock and its biblical associations with firmess of faith. 45 Epifanij, employing it in the prayer for the Permian Church much as the image of the lam, strengthens the impact through repetition of the word kamen' and concludes with an authoritative quotation:

$$
\begin{aligned}
& \text { юге ( церковь FК) утверди Господи, на камена }
\end{aligned}
$$

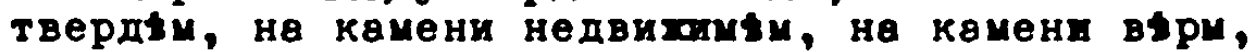

$$
\begin{aligned}
& \text { на камени заповьдеи твогх, на камени исповьданив } \\
& \text { твоего, на камени иерковным: сам бо рекл есп, } \\
& \text { Господи: ня сем камени созихн иерковь мор, } \\
& \text { и врете = повв не удольртв ег. }
\end{aligned}
$$

Nautical imagery was found in classical times; Roman poets frequently compare the composition of a work to a sea voyage, but in early Christian literature the ship came to mean the Church, in which the faithrul are borne over the sea of life (the Lark of Peter). 46 In Kievan literature, the boat usually represents the human soul, the voyage its fate, and the

12. op. cit., p. 131 discussing the passage on f. 699. See also H. von Eicken, Geschichte und System der mittelalterlichen lieltanschauung, Stuttgart, 1887, p. 630.

13. Life of Ioan, pp. 9, 12.

44. Life of Sava, p. 334 .

45. Natt. 16, xviii; 7, xiv.

46. Curtius, op. cit., pp. 126-30. It was one of the topoi of the exordium and is used by unte. 
helmsman who steers it into the harbour of quiet waters the individual or more often a spiritual or secular leader. 47 Similarly, in the Serbian Life of Sava, it is the king, Sava's brother who is the helmsman, 48 but in Evtimij's vitae, he represents the saint. 49 The ship may be variously men in general or the Church, thus returning to the original Christian interpretation. 50 Epifanij also describes the Permian Ciurch in terms of a ship, but his is a ship doomed to perish on the sea of life without the guiding hand of its helmsman Stefan. 51 by far the most striking example of this image in the Life of Stefan is in the Author's Lament, whel, ns with the barren fig tree, Epifanij paints an elaborate picture to convey his sense of his own frailty:

безакония мов Јмножишвся зьло, и безакониа моя волнах прилагаю м:орскых, помыплениа же в ялицах ПрОтивнЫХ МИ ЕВТр: УвЫ МнБ, КәКО СКОнчаю мое житие, како преплову се иоре великое и простренное, ширшееся, печалное, многомутное, нестояще, смятупеся: како препровоку душевную ия лодию промеху волнами сверьпмми, како избуду треволнениа страстеи, лють погрухвюся в глубинь зол, и звло потопляяся в безднь грвховньи: увыи инь, волнуяся посрьды пучины китиискаго моря, и како постигну в тишину Үюиленив, и како доиду в пристанище покааниа, но яко побрыи кормник сыи, отче, яко правитель, яко наставник, из глубины мя от страстеи возвед...

The dangers to tile sailor on the sea of life are here highlighted to an unparelleled degree, and the application of the image to the

47. Adrianova-Peretc, op. cit., p. 45. Nb, the Slavonic version of the Nomokanon was called the hormčaja kniga.

4o. Life of Sava, p. 256

49. Life of loin, pp. 15-9; Life of Ilarion, p. 58 .

50. Life of loan, tp. 13-9; Life of llarioll, p. 58

51. f. 755 . 
hagiographer is a novel development in vitae though strikingly similar to the personal tone of Kirill of Nurov's prayers. 52

The military image of the warrior with its associations with warrior saints like $\mathbf{~} t$. Demetrius was comon in vitae in which the subject faced opposition to his teaching. Furthermore it was one of the images which even in the Bible, had been developed into an elaborate symbolic picture of the warrior of Christ armed with virtue, his feet shod with the gospel of peace, going out to do battle and, paradoxically, to preach peace. 53 This imane adapted well to Epifanij's presentation of a missionary as a candidate for canonisation, and indeed as Konovalova demonstrated, military symbols are among those which appear constantly in the Life. 54

The presence of symbolic pictures in the Life should not obscure the large number of images not subjected to any particular development. Thus the image of wounds representing sins springs from the Old Testament, and is exceptionally common in early Russian literature. 55 Its extension to include the saint as the doctor who can heal spiritual ills or wounds, is likewise comino, and is found in the vitae of all three writers. Other imanes uppear as metaphorical phrases in the life in exactly the form they took in the Bible; such are 'the gates of truth', 56 'the bath of

52. pp. $251,327$.

53. Ephes. 6, x-xvii.

54. Konovalova deals very fully with military imagery in the Life but unfortunately she is unaware that the long symbolic picture of the warrior of Christ on $f_{.} 666 \mathrm{v}$, , is a quotation, albeit not entirely accurate. None of the details of symbolic armour may be attributed to ipifanij's imagination.

55. Jer. 30, xvii and 6, vii; Ps. 38, v. Sremerskij (Naterialy), devotes a special section in the entry under strup to its metaphorical application.

56. I. 672, cf Ps. 113, xix. 
regeneration', 57 'the unfading crown of glory', 58 the chosen vessel.59 'the yoke and burden', 60 'hunger and thirst', 61 'the bridle', 62 'the eye of the heart'.63 The large majority of these also occur in Evtimij's and Domentian's writings as are others not of biblical origin like 'the wings or grace' or 'the flame of passion'. 64

One traditional image seems characteristic of the period - the symbol of spiritual nourishment as a table. Employed by lipifanij in both the Life of Stefan and the Life of Sergij, ${ }^{65}$ it was equally popular in art of the period, notably in Kublev's famous icon of the Trinity, where the table round which the three angels representing the Trinity are

57. ff. $737,733,753$, cf. rit. 3, v.

53. f. 718 , cf. 1 Pet. 5, iv.

59. f. 6.22 .., cf. II rim. 20, i.

60. f. 664 v., cf. Hatt. 11, xxix-xxx.

61. f. 636 , cr. Siatt. 5, vi.

62. f. 715, cf. Ps. 32, ix.

63. f. 638, cf. Ephes. 1, xviii. Curtius, op. cit., p. 136 shows that this imaje stems from Plato's lejublic.

64. f. 631; f. 765. A number of common images in the Life are contained in biblical quotations, such as the comparison between the things of this world and the flowers of the field (ff. 655, 757 from 1 Pet. $1, x \times i v$ ), betwcen words and the sweetness of honey (f. 699 and I's. 119, $c i i i$ ) or enemies and a swarm of bees ( $f .672 \mathrm{v}$. and Ps. 111, $x i i)$. The selection of so many quotations containing symbolic images is a measure of Epifanij's predilection for them.

65. F. $736 \mathrm{v}$. and pergij voll Radonež, p. 3. Other writers of the period to use this image are Teodosije in the foreword to his Life of Sava, and Danilo, the Serbian hagiographer, (given by 'ulić in 'irpsko pletenije sloves', p. 124). It is also found in Grigorij Camblak's iulogy to Kiprian, p. 181. Just as the icon of the Trinity is not new to this period, so too this image was employed in moderation earlier, for example by Kirill of Turov, who terms the Virgin Mary trapezo xl ba Životnago in his prayers (Gebcte, p. 290). Its origin is probably the Posledorantie ko sy pricalyeniju, Kanon, pean' 3, bogorodičen. 
seated is a sybol of epiritual nourishment. On it stands the cup of love. The icon, which as a mole aybolises peace and lore, reflects Publev's sophisticated absorption of sybolisw; whereas earlier icons of the Irinity showed Abrahar and Sarah welconing the angels with Iood on the table, Publer dispenses alnost entirely with the details of the Old Testament atory. 66 Both icon and vita display the sam ature approach to sybolism that warks the high water of adiaeval attitudes at this period. Though Rubler's athod is to denude the traditional inge of its detail, and Epifanij's to add new ones, the intention in both cases is spiritual intensity.

Imagery in the bife is thus all pervasive, essential to Bpifanij's portrayal of Stefan as a worthy candidate for canonisation. It even form the basis of the whole of the Lament of the Permian Church where as elsewhere it is highly traditional. 67

Apart from images from the physical world, Epifanif is also fond of comparisons with biblical personages. At first sight, these appear to have 1ittle in comon with the symbolic interpretation of phenomena, being straight comparisons between a character in the vita and a 'historical' personage. However, mediaeval veneration for the Scriptures was so profound that famous biblical characters were transformed into archetypal images - to take a simle exaple, Cain is the archetypal arderer who kills a close relative. Thus Nestor in the Lection term Svjatopolk a second Cain for his killing of his two brothers Boris and Gleb. In this way, biblical characters became symols themelves, a vital aid to the glorification of a saint, who wa thereby show to be as holy as the nost venerable biblical personage. These comparisans, together with parallels

66. N. Demina, Troica Andreja Roubleva, M., 1963, p. 45; L. Ouspensky and v. Lossky, The Meaning of Icons, trans. G. Palwer and E. Kadloubovsky, O1ten, 1952 , P. 203.

67. Holthusen, op. cit., passim. 
with Christian saints abound in Byzantine hagiography. 68 In Kievan Lives they are not very numerous; in the Lection for example, there are only eight. Furthermore, contrary to Byzantine practice which placed the majority in the conclusion for panegyrical purposes, they all occur in the main part of the work. 69 Epifanij's concentration on analogies with biblical personages in the three Laments conforms to Byzantine canons, but about a dozen examples are contained within the main body of the work. These are mostly clustered together for added emphasis: the shaman for example is presented as the archetypal foe of Christianity, through five parallels with New Testament figures regarded as personifications of evil. 70 "hen single parallels occur, they are longer and mure elaborate than in Kievan literature. Thus the passage describing stefan's election as bishop of Herm', is presented in the form of an elaborate parallel with the elevation of jaul to the throne in Israel. ${ }^{71}$ Epifanij was evidently aware of cynical critics who would read an element of self-seeking into jtefan's journey to Noscow to request a bishop, and attempted to allay criticism by means of an elaborate biblical parallel. In fact the parallel is not exact, for jaul, it will be remembered, was out searching for his father's asses when he decided to request the help of the prophet jamuel, who informed him of his high destiny. Stefan on the other hand, went to . ioscow specifically to seek a bishop. Since Eipifanij's uncritical audience probably did not notice the discrepancy, the parallel succeeded in its aim.

68. They are also to be found in prayers: see Kirill of Turov's list of biblical figures as symbols of various Christian virtues, Gebete, p. 317.

69. Gleb is compared to Lachariah (p. 13) and Vavid (p. 3); Vladimir to Placidus (p. 4) and Constantine (p. 4); jvjatopolk to cain (p. 9) and Julian (p. 14); Boris to St. Komanus (p. 5); svjatopolk and Boris are together compared to Joseph and Jenjamin (p. 7 ).

70. ff. $69:-6 \% 9$.

71. ff. 719 v. - 720 from I sam. 8. 
In the Laments, comparisons with biblical personages are both more comon and more elaborate. The Lament of the Permian Church contains a long string of embroidered parallels, developed from Gregory of Nyssa's runeral oration on Meletius, which liken the grief of the Permian Church to the sorrowing of various biblical figures, mainly female.

Epifanij draws all his comparisons with biblical personages rather than saints or figures from ecclesiastical history, probably because he felt they carried more weight, a sharp contrast to Nestor, who drew only half his parallels with biblical characters. There is anly one exception to this; the comparison between Stefan and other apostles and patron saints based on the famous passage in llarion's sermon which reads:

хвялит те похвальними гласы Римвская страва Петра и Павла, ими те выровапа в Мнејса Хрнста Снна Бота: Асна и Ефес, п Пати - Новнва Богословв: Ивдня - Фоиу, Егmеs - Марка: вся стран, град, и людые чтут и славят коеготдо их учитедя,

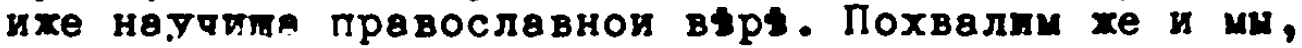
по силн непег, малими похвалвми - велвква и дивнав сътворпаго нашего учителя и настввника, великаго кагана нвшев земля, Владимира, внука стараго Игоря, сина же славнаго Святослава...

(pp. 99-100)

The passage was frequent ly adapted by writers praising local saints, and is even found in the Lives of Simeon and Sava. The formula became a toplos which was gradually amplified to include toms and countries (and their patron saints) not in Ilarion's original list. Epifanij's adaptation combines all the original details with those in the Lives of Prince Vladimir, Leontij of Kostov and Metropolitan Peter of Hoscow. 72 Again, not content with the flowers gathered from one work, he feels compelled to gather a nosegay of all the varieties he can Iind. It is, of course, very important that this comparison should not only strike a familiar

72. Nikol'skaja, op. cit. 
note, but should particularly impress his audience, since Perm' and Stefan's exploits were so remote and insignificant to them. Epifanij's adaptation of this famous passage reads:

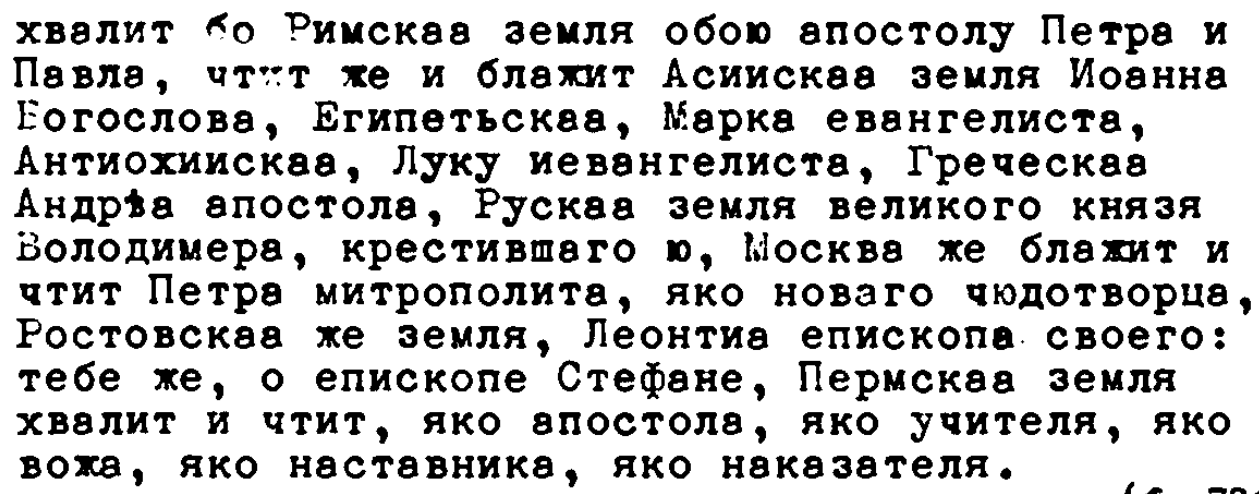

This famous analogy is perhaps less a comparison with biblical archetypes than with historical events. History to ipifanij meant the same as to all ecclesiastical writers; the history of fian from the Creation through the stories of $01 d$ and New Testaments to an account of his 'endeavour to conform to the Law revealed in the New restament'. 73 In effect, it was the history of the Church. Parallels with historical events were thus either drawn from the Bible or from ecclesiastical history, and performed a valuable function in supporting contentious points or eulogising the saint and his achievements. No less so for tpifanij, who lacking many precedents for a missionary saint, drew on history. To the extent that the events chosen as parallels are those hallowed by tradition, they are as authoritative as comparisons with archetypal billical and historical personages. jo in his discussion of the invention of the fermian alphabet by Stefan, Epifanij, sensitive to possible criticism, selects the creation of the Greek and Slavonic alphabets as parallels. 74 iut his polemic intentions allow him to present stefan's achievement as the greater for being accomplished

73. ille, op. cit., p. 131.

74. ff. 727 v. $-732 \mathrm{v}$. 
unaided. This ia similar to his comparison between Stefan and Joseph, which shows Stefan to advantage in giving away wheat to the Permians in times of need, while Joseph sold his to the Israelites. 75 Nurthermore, here he adds force to his argument by switching to lyrical praise in the famous passage of repetition of the root edin.

The strong polemic element apparent whenever Epifanij discusses Stefan's work in factual rather than emotional terms engenders enormously long historical comparisons. He forestalls criticism of the usefulness of Stefan's mission by enumerating the countries and cities visited by the apostles. His aim is to show that great as their achievements were, they could not have been expected to accomplish any wore in their lifetimes; the conversion of Perm' had to be left to others. 76 In this way, Stefan is compared to the archetypal Christian missionaries, the apostles, which prepares the way for the epithet apostolom naslednik applied to him in the conclusion to the Life. 77 Likewise, when discussing the invention of the alphabet, Epifanij shows how the break-up of the world into many peoples, each with its own language, was foretold in the Bible. It proved beneficial to mankind because each race made a contribution to the development of the human race as a whole; the lgyptians invented geometry, the Assyrians astronomy, and so on. 78

Similar intentions may be discerned in Epifanij's enumeration of the great events of biblical and Church history that occurred during March, the month selected for the feast day of the Permian Church. 79 Some of

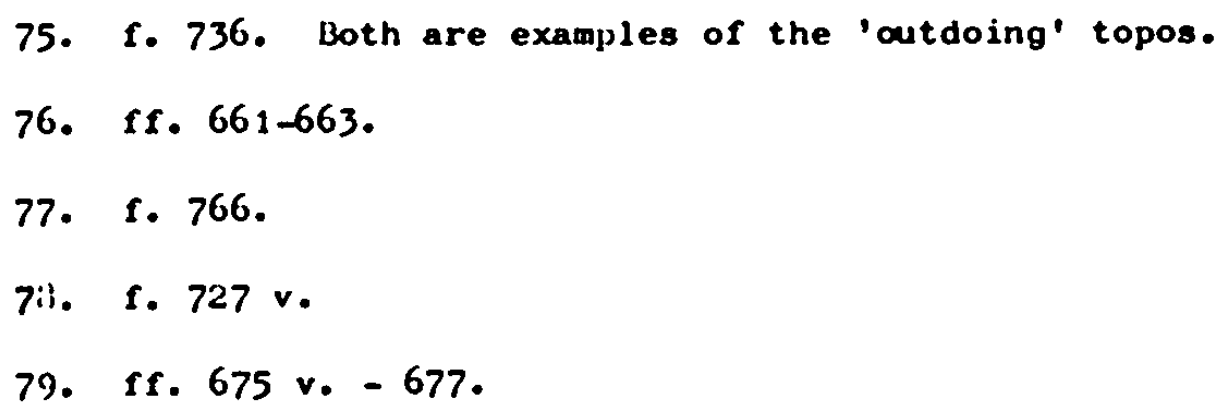


the authority of these other festivals is transferred to the new one by inference, merely through their juxtaposition in the Church calendar. Historical parallels in the Life of Stefan also furnish proof for stefan's arguments in the debate with the shaman in the same way as biblical quotations. In Nomentian's vitae, they occur only in debate; thus Sava in his argument with heretics cites the decision of the great Church Councils as support for his views. 80 both livtimij in the Life of Ilarion, and Epifanij in the debate in the Life make exactly the same analogy, which may, as a consequence, be regarded as a hagiographical topos.

On the other hand both Evtimij and Domentian frequently employ the device of comparisons with biblical characters. One feature of their vitae is the use of parallels drawn between the saint and Christ or God, as when Domentian likens Java's powers of healing to Christ's and Peter's, or filoteja speaks to a sick man just as Christ before her ${ }^{81}$ These might at first sight seem blasphemous, but generally speaking Uomentian and Evtimij, like their Byzantine counterparts, avoid analogies with the divine nature of Christ or God, preferring parallels with actions or incidents. Epifanij on the other hand never draws any form of analogy between Stefan and Christ or God, partly due perhaps to native hagiographical tradition, where such analogies are rare, but also to a pleasin. sense of propriety, which periits favourable comparisons with jt. Cyril or Joseph but rejects those with divine figures. Epifanij's strong sense of moral hierarchy, which elevates other men above himself, Stefan above other men, God above stefan, seems to preclude such audacious analoyies. Evtimij's comparisons with biblical figures are either purely symbolical, such as the description of Ioan as a second Abel or Isaac, 22 or

30. Life of Sava, p. $23 \%$.

31. Life of sava, p. 211; Life of Filoteja, p. 38, quoted by Vranska, op. cit., p. 67 .

32. p. 10, quoted in ibid., 1. $6: 3$. 
more lengthy comparisons with whole incidents. 83 They are never longer than necessary, are apt and on the whole successful. Radčenko also pointed out that they occur more frequently in Evtimij's works than in those of Byzantine contemporaries, 84 perhaps because of Evtimij's strongly ecclesiastical education. Domentian likewise makes this an important device in his stylistic repertoire. Sava, for example, is compared to Christ, Moses, David, Isaiah, Elijah, Gideon, Abraham, the Three Kings, John the Baptist, Paul, Ignatius and St. Cyril. Both Evtimij and Domentian, unlike Epifanij avoid clusters of analogies though Domentian does employ a similar technirue of extended parallels. One of these compares Sava to Moses, at the same time bringing in parallels with Elijah, Isaiah and Abraham and describing Serbia as a second Jerusalem. 85 Dut Uomentian is more adventurous even than Epifanij - this example lasts for four pages, and acts as another means of abstracting the events of java's life.

Comparisons with historical events, other than stereotyped refutations of heretics appear thus to be a feature specific to the Life of Stefan, where they argue the value of Stefan's work or magnify the importance of l'crinian Church and alphabet. Comparisons with biblical figures on the other hand, whether brief appearances as personifications of a particular Christian virtue or longer parallels with episodes from their lives, are a feature of all three writers of pletenije sloves, consonant with Byzantine practice. It would appear that this type of analogy became more common in Slavonic hagiography at this period, at the same

33. For example the comparison between Abraham living near the oak of Plamre (an extremely popular story in the Middle ages), and loan settling in an oak tree (life of loan, p. 12).

84. op. cit., p. 287.

35. Life of java, p. 23 i. 
time being employed to greater dramatic effect. Both Nomentian and Epifanij employ extravagantly long comparisons, or (mainly in the Life of Stefan) clusters of analogies. As with other devices, while Epifanij uses them largely for their emotional panegyric effect, Nomentian employs them as a means of distancing.

But though similes drawn from the Bible or Cimrch history are a timehonoured stylistic feature of Lives, the same is not true of Epifanij's numerous detailed symbolic pictures, whose appearance should perhaps be attributed to the influence of Kirill of Turov's serinon for the week after baster, which was immensely popular in lassia, and almost certainly known to Epifanij. 86 The debt he owes Kirill is obvious in his verbal picture of sowing and reaping. 87 we may compare this series of symbols in rhyming phrases with a sentence from the Life:

ныня ратаи слова словесныя уньца к духовному ярму приводяще, и крестное рало в мысьленых браздах погрухающе, и бразду покаяния прочертаюmе, сьмя духовное всыпающе, надеками будущих блат веселяться,

(p. 417)

and :

тВм чтец тя яко двлателя винограду христову, яко терние востерзал еси идолослужениа от зенля liермьскиа, яко плугом проповьдию взорал еси, яко сьиенем учением словес книяных насьял еси в брвздах сердечных...

Kirill's other method is to paint in details more fully, only subsequently adding an interpretation:

ныны новоражаемы агньцы и уньцы быстро путь перуше скачють и скоро к натерем вззвратаютеся веселяться, дв и пестыри свиряюще веселием Христв хввлять. (p. 416$)$

86. This sermon is in fact partly taken from Cregory of liazianzus; (see $\therefore$ Vaillant, 'Cyrille de lurov et Grégoire de Nazianze', isi, $x \times v i$, laris, 1950, pp. 34-51), but ipifanij is ferhaps more likely to have displayed a patriotic bias in his selection of favourite works.

i:. $\mathrm{su}$ ira, !.. 154 . 
This type of symbolic picture allows the reader to first form a clear image, here of the lambs and calves gambolling in the meadow, before receiving an explanation of its significance. It possesses a stronger lyrical effect than the type of symbolic description in which each detail is elucidated as it is introduced, partly because it is closer to a genuine observation of nature. Epifanij never paints such lengthy symbolic pictures as Kirill - they are hardly suited to the vita, but he may introduce an element of pathos, as when he enlarges on the dangers that beset the Permian rlock without its shepherd. 88 There is a sharp difference here between the two writers; Epifanij's pictures usually convey a strong emotional effect, whereas Kirill's possess an elegant charw. Exceptions include the description of sowing and reaping above, which is 1 ess rhythmical than Kirill's. But when Epifanij so desires, he can attain an unrivalled emotional tone by the addition of either pathetic details, exclamations, paronomasia or rhythm. Thus in the passage describing his despair at how to cross the sea of life alone, he enriches the effect by the addition of exclamations of alarm, the rhythmic repetition of kako and numerous adjectives emphasizing the hostility of sea and storm.

Though it may be deduced from their existence in Domentian's vitae. that symbolic pictures were not introduced by Epifanij into hagiography, it seems clear that their proliferation and elaboration in the Life may be attributed to the influence of Kirill of Turov's serwons. The added emotional colouring in these pictures in the Life may also stem from Kirill of Turov, though from his prayers not his sermons. The adoption of stylistic features from other ecclesiastical genres is one of Epifanij's methods of lending his work increased impact. But stylistic borrowings are not used indiscriminately; in imagery, Epifanij's hallmark is variety, 
gained by elaborating traditional images, or subtly adapting their symbolic meaning to suit the context, by repeating the symbol with various related interpretations or quoting its source in the Bible. Neither Evtimij nor Domentian offers such variety. The former, adhering to Byzantine standards of stylistic restraint, makes aptness not novelty his aim. Images nonetheless lend a dash of colour to Evtimij's forinal prose. Clearly he was aware of their properties, for he not only employs more imagery than his Byzantine contemporaries, but also uses it more intensively in the relatively poetic encomia than in the vitae. Lomentian, unlike Evtimij is not averse to developing traditional imagery at length, but its function is nearly always to elevate Sava or Simeon above other mortals.

All three hagiographers display a sophisticated attitude to their inherited store of images, tying them in with their personal approach to hagiography. It is not possible to agree with Lixačev's suggestion that 'the style of the period of the so-called Second South Slavonic Influence was undoubtedly hostile to mediaeval symbolism as the basis ror mediaeval images and metaphors'. He argued that the attempt to affect the feelings rather than persuade the minds of the listener destroyed the dual meaning of the image. 89 Certainly Lpifanij makes his images at times more cmotiunal than had previously been known in hagiography, but this is always put at the service of the symbolic meaning. The picture of the lost sheep is steeped in pathos but it is always clear that Epifanij is referring to the Permians. The grief of the sheep (the passaye is in the first person plural), is a human emotion which connects it even more ouviously with the group of people represented by the image. ihat

89. Poetika, p. 166. 
ipifanij adds to the symbol is emotion, where previously lost sheep equal lost souls, here sad and lonely lost sheep equal sad and lonely Permians. This does not destroy the symbol in favour of a more realistic image but reinforces it. This conclusion may be confirmed by noting that highly emotive images are found in Kievan literature as well. Even though Epifanij's dissatisfaction with prevailing hagiographical style led hila to seek means of strengthening its emotional powers through the adoption of aspects of style from other ecclesiastical genres, he is not hostile to the system as such. Symbolism on all levels is essential to an understanding of the Life of Stefan of Perm'. At a later period this dissatisfaction with the available means of expression within a genre might well lead to a rejection of the genre itself. Here it is reneval that occupies Epifanij not rejection. 
PA R T III

PLEONASTIC AND ACOUSTIC TECHNIRUES 


\section{CHAPTEIT I Compound words}

The language of the Life of Stefan of Perm' is strikingly rich in compound words or composita, that is words comprising two or more meaningrul roots, characterised by unity of meaning and belonging to one of the usual lexico-grammatical categories of Kussian and Church Slavonic. 1 Their presence is not unusual, for such words form part of the vocabulary of all itussian and South Slavonic high-style literature, their popularity deriving ultimately from Byzantine ecclesiastical literature. ${ }^{2}$ bven in classical Greece they were regarded with approval, though aristotle in his thetoric advocates only sparing use of them. 3 Later writers ignored his advice, and as prose became increasingly more ornate, so too compound words came to be employed to a degree that would have offended his sense of restraint. When Cyril and Methodius undertook the translation of Christian literature for the Slavs, they resolved the problem of conveying the subtleties of abstract thought by calquing Greek compound words into Slavonic. The Slavs were thus endowed with an abstract vocabulary which, because consisting largely of compounds, was easily comprehensible to the

1. The definition of E. A. Vasilevskaja in Slovoslolenije $v$ russkom jazyke, M., 1962. Nost scholars have adopted a similar definition though some, like I. Klemiensiewiczówna, Wrrazy ziozone nowszej polszczyzny kulturalnej, Kraków, 1951, emphasize that each element wst exist as a eparate weaningful word for the compound to be regarded as of dual origin. See also S. I. Abakumov, $O$ složnyx slovax v russkom jazyke', tusskij jazyk v gkole, 3-4, M., 1946, pp. 18-9. It is not always possible however, to decide whether an old thussian compound word comprises two meaningful roots. It is perhaps more important firstly, that each of the two elements should be productive (that is rejularly used in the formation of new compounds), and secondly contribute to the overall stylistic impreasion of the work; hence the exclusion of words compounded in the Common slavonic period like nevêsta or odinadcat', and inclusion of calques from Greek and those words modelled on them, even where one elewent has lost its independent meaning (such as veleglasnyj, and those wards beginning ne-, bez- or the superlative pre-).

2. See the vast number in E. A. Sophocles, Lexicon of the Roman and Byzant ine periods, N.Y., 1870.

3. Aristotle, Rhetoric, III, 3. 
new converts. \& Fom the beginning therefore, such words tended to be associated with unworldly rather than worldly things, and were employed primarily 'in high style literature, possessing an emotianal tinge which permitted their use as an artistic device in themselves. 5 lititers did not rest content with the vocabulary they inherited, but composed new words in response to the need for subtlety and greater expressiveness. 6 In adopting this method of word-formation, they showed that they were aware of the dual origin of their models, the 'internal sense' in Unbegaun's terminology.?

The popularity of compounds in ecclesiastical literature and their productive nature are attested for the whole of the mediaeval period. The striking stylistic use of compounds in the life of stefan must be set against this background. Speranskij, ${ }^{8} \mathrm{~K}_{i \text { Zevskij }}{ }^{9}$ and Lixacev $^{10}$ have all remarked on the increased incidence of compounds in Kussian literature from the late fourteenth century on, attributing this to the influence of Evtimij's literary school, but kulić rightly pointed out that, since they

4. H. jchunann, Die griechischen Lehnbildungen und Lehnbedeutungen im .ltbulgarischen, (Slavistische Verbffentlichungen, XVI), riesbaden, 195is, p. 6 .

5. L. V. Vjalkina, 'složnyje slova $v$ drevnerusskom jazyke $v$ ix otnošenii k jazyku grełeskogo originala', Issledovanija po istoričeskoj leksikologii drevnerusskogo jazyka, N., 1964, p. 109.

6. G. |tuttl-worth, 'Problemy mezslavjanskix i slavjano-neslavjanskix leksičeskix otnošenij', , umerican Contributions to the vth Congress of Slavists, The liague, 1963, pp. 193-212.

7. 3. O. Unbegaun, 'Le Calque littéraire dans les langues slaves', Nes, XII, Paris, 1932 , p. 19.

3. A.. I. Speranskij, 'Iz nabljudenij nad složnymi slovami v stile russkoj literaturnoj skoly XV-XVI vV.', Iz istorii russko-slavjanskix literaturnyx svjazej, M., 1960, j. 162.

9. D. Ciževskij, llistory of Russian Literature from the XIth century to the end of the Barogue, The lague, 1960, pp. 178-9.

10. '. Nekotoryje zadači', p. 98. 
abound in thirteenth century Serbian literature, intensified use of composita should be regarded instead as a feature of hagiography composed in pletenije sloves. 11 Observations of this nature have never been supported by hard evidence, establishing whether vitae written in pletenije sloves employ either wore numerous or more interesting composita, or Whether Epifanij's stylistic treatment differs in any way from tvtimij's or iomentian's.

Yet quantitative differences are easily measured. In the Life of Stefan, 410 different compounds appear nearly 800 times, an average of approximately twenty seven per thousand words of the text. In early Slavonic hagiography, in the Life of Methodius, on the other hand, there are only twenty four composita, an average of seven per thousand words. This is perhaps an unusually low figure, for in Kievan hagiography in the Lection on Boris and Gleb the average rises to 15.5 , and in the Passion and Encomium to 17.5. Judging by the results of an analysis of four Kievan sermons, ${ }^{12}$ composita constituted a sore important stylistic element of homiletic style, for though Kirill of Turov employs only about seventy five per cent as many as Epifanij, llarion uses proportionally the same number though the frequent repetition of the word blagodat' gives this rigure an artiricial ooost. 13

11. 'jrpsko pletenije sloves', p. 127. Talev, op. cit., pp. 33-5 notes that composita are a distinctive feature of both secular and ecclesiastical literature in fourteenth century Bulgaria. Thus though not exclusive to hagiography, the intensified use of composita nevertheless remains an innovation in vitae. See infra, pd85 ff.

12. Lirill of Turov's sermons for l'alm Sunday, Laster Lay and for the sunday after taster, and Ilarion's jermon on Law and Grace.

13. Twenty $s i x$ times in the first twenty pages of the printed text, out of a final total of 165. Figures in all cases are tentative, since the number of composita depends upon the decision of the editors of these texts as to whether compounds beginning ne- for example, are printed as one or two words. Uružinin followed no consistent line in this. lowever proportions are roughly accurate. 
But though Epifanij does indeed employ composita more than most hagiographers, he is more sparing in his use of them than either Evtimij or Domentian. In the latter's Life of Simeon there were proportionally sixty per cent more than in the Life of Stefan and in Evtimij's Life of Filoteja, a work $s i x$ and a half times shorter than the Life, there were as many as two hundred, slightly more proportionally than in the Life of Simeon. This contradicted Speranskij's assertion that Evtimij himself employs composita with some restraint (though his successors like Grigorij Camblak overburden their work with them). 14 for Camblak's Encomium to kiprian has proportionally only just over half the number of the Life of Stefan and a mere third as many as Evtimij's Life of

\section{riloteja.}

Compound words appear to be connected with the search for greater expressiveness and emotional impact in hagiography composed in pletenije sloves. This may be confirmed by noting that compounds are morc frequently found in the exordia and conclusions of vitae, ${ }^{15}$ and are a regular feature of religious poetry. ${ }^{16}$ It is likely that as with other devices, their popularity is due to the incursion of poetry into hagiography at this period. The Slavonic translation of Hanasses Chronicle with its artificial but ingenious calques might have influenced Evtimij to employ unusual expressive composita, but it could not have affected the number he employed, for there are nearly twice as many per thousand words in the Life of Filoteja than in the Slavonic Janasses Chronicle. 17 In view of

14. speranskij, op. cit. p. 162 .

15. ibid., p. 167 .

16. ibid., p. 165 .

17. Die slavische Aanasses-Chronik, from the edition by J. Bogdan, with an introduction by J. Schropfer, (Slavische Propylden, XII), Aunich, 1966. See also CiŽerskij, History, pp. 149, 157; Talev, op. cit., pp. $41-3$. 
the date of it: appearance in Slavonic (c. 1340), it could not have

influenced Domentian at all nor indeed Epifanij, for it produced no effoct on pussian prose style before the aid-fifteenth century. 18

Since composita occur with greater frequency in the vitae of Evtinij and Domentian, statistical comparisons alone cannot explain the interest aroused by their troatment in the Life of Stefan. But to deterwine the degree of their originality is a step fraught with dangers. In the absence of any adequate dictionary of Old Pussian, studies of the origin of composita in any one work are severely inhibited, as was demonstrated by Istrin in his analysis of the language of the Russian translation of the Chronicle of George Hamartolos, 19 and by Ponomarev's study of Polikarp's dictionary of 1704.20 Therefore Epifanij's composita have been checked not only against Sremerskij and Miklosich, but as many other sources as possible. 21 Even so, words that almost certainly are not neologism in

18. Speranskij, op. cit., pp. 160-97.

19. V. M. Istrin, Xronika Georgija Amartola $v$ drevmed slavjanorusskom perevode, vol. III, L., 1930.

20. V. J. Ponomarev, 'K istorii složnyx slov $v$ russkom jazyke (složnyje suscestritel'nyje $v$ Leksikone Fodora Polkarpoval', Doklady i soobscenija Instituta jazykomanija AN SSSR, no. 4, M., 1953, pp. $14-78$.

21. Slovník jazyka staroslovenského, Praque, 1958, ff. Istrin, op. cit., p. 184 ( 1 ist of conposita). N. A. Mescerskij, Istorija iudejskoj rojny Iasifa Flavija v drevne-russkom perevode, Slovoukazatel', p. 532. Vjalkina, op. cit., p. 114., M. Weingart, Byzant ingke kroniky v literature církevndslovangke, Bratislava, 1922. Schumann, op. cit. p. $7 \mathrm{ff}$. where Miklosich listed a word but gave no textual references, or both Sremevskij and Miklosich cited a later text, the word might still have been created by Epifanij, and therefore was included in his list of neologisws. C. Buschbeck, zur Wortbildung der Substantiva und Adjectiva in Altrussischen (an Hand des Wortmeterials Zweier Viten Epifanij Premudryjs), Mannheim, 1969, analyses nouns and adjectives (including compounds and neologisms) in the Lives of Stefan of Perm' and Sergij of Radonež. Unfortunately her conclusions are based on jremevskij, which inevitably casts doubt on the reliability of some of her vork. She is avare of the danger of firmly attributing neolo$g$ isms to Epifanij himself, opting instead to classify form and words as earlier or contemporary formations. It is further regrettable that she does not seek to resolve problems connected with compound neologisms in the period of the 'Second South Slavonic Influence', such as whether they are modelled on Bulgarian composita or oven borrowed. Nor does she look at styl ist ic function in any dets id lo/10/2019 05:55:48AM 
neologisms are exactly the type of composita any writer at any time felt free to invent. If Epifanij did invent them, he intended them to enrich the intricate patterns of his pletenije sloves as?

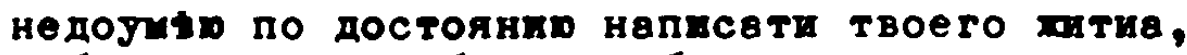
и блатонравия и благопребиввнив.

irore unusual forms like volkoxił̌̌nyj, goroplennyj, novosložiti or skudopamjatstvo were likewise created to fit in with Epifanij's word pitterns, 24 and were often a compression of phrases already existing in llussian. 25 From this it is clear that Epifanij was fully aware of their dual origins, even exploiting this in his word weaving through the repetition of each eleinent separately:

сего ради не подобвет вам во многи боги выровати, ете есть многоболие лесть куйрсқав.

Nevertheless a distinction must be drawn between his neologisms and those of hievan and early Slavonic hagiographers. Even if Nestor in his Lection does coin new words, they are modelled so closely on existing calques, forms in blago-, dobro-,bez- or ne- as to be indistinguishable from common Christian terms like blagodat', strastoteryec, or bogorodica. by contrast, many of Epifanij's neologisms display a startling originality, and it is this that has led to so much comment. Since Epifanij was not influenced by the style of Manasses Chronicle, both form and number of the new composita are quite amazing.

Though Evtimij alone of the three wight have been influenced by Manasses Chronicle, searches for highly original and expressive composita produced little result. Not that he did not coin them at all, but werely

24. infra, p. $182 \mathrm{ff}$.

25. In impression confirmed by 0 . $r$. Konovalova personally, on the basis of her examination of the Old fussian dictionaries on cards in the Institute of Russian Language of the Soviet Academy of Sciences in iloscow. 
that each element forms part of other composita elsewhere found in occlesiastical literature. Exmples are mogolgkaryj, unovrodnyj.

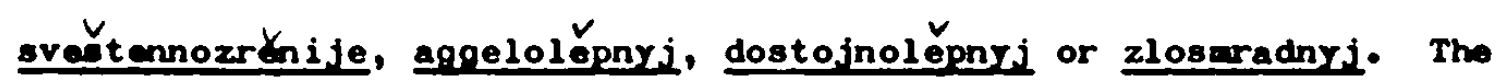

first elewents in these words are particularly comon: two, nogo- and zlo- are among the wost productive elements of all, 26 wile sremerskij lists fifteen composita beginning svjascénno-, seven with dostojno-, four with upo-. Agpelolępnyj actually appears in his dictionary though quoted frow a fifteonth century text, and in Miklosich from a sixteenth century Serbian text. Second elements are somewhat more unusual. Domentian's compound words by contrast are highly conventional in form, with each element familiar from other ecclesiastical composita; take for example bogozratije, bogomudryje or mogosl'mo, which may at most bo new grammatical formations. The most likely neologisms are gorémyslije and mogomol'b'no, but even these confirm to established patterns. It is probable that Evtimij was influenced by the rogue for new composita in fourteenth century Bulgaria to devise nore expressive neologisms himelf. But he was careful to build them from components already existing in the ecclesiastical literary tradition, thus combining greater expressiveness with the authority of tradition. Domentian on the other hand employs composita largely as a means of distancing. 27

By their very form, modiaeval composita possessed an essential artificiality that made them alien to everyday speech and hence peculiarly suited for discussion of spiritual watters. They had the advantage of being part of a special language, wich because of its strengthened associations at this period with the style of religious poetry possessed strong ewotional overtones. Composita at this period as a result tend to

26. E. Fodor, 'Slovosloženije v vostočnoslavjanskix jazykax', Romanoslavica, IX, Bucharest, 1963, pp. 95-107. Fodor bases her analys is on Sremerskij, which she recognises as being incomplete. Though Bulgarian tradition may differ from Pussian, these differences are not likely to be significant. 
be avaluative rather than descriptive. As Lixačer pointed out after studying composita in the fourteenth century Bulgarian Life of Romil, their first component strengthene the evaluation inherent in the second or defines it morally, and the word as a whole is intended not to describe accurately but to affect emotionally. 28 Epifanij's original conposita include numbers of this type; strannolǒpnyj, ľeumilenije. skorovyćenije, and dobropagjatstro are good examples. Siallar instances occur in Evtinij's and Domentian's vitae; Domentian calls Sava and Siwoon oba sretlodus'na i rav'noobrez'na gretil'nika, 29 wile Evtiaij uses the expression zlosmradnyj trup' in the Life of Potka and dostojnolypnoje ime in the Encomium to Constantine and thelene. 30 Furthermore, a large majority of Evtimij's unusual evaluative composita appear not in the vitae but in the encomia mere description is more decisively subordinated to panegyric. Of course composita of this type had always been numerous, but they predominated previously only in prayers, as for example in Kirill of Turov's plea for intercession to the angels:

$:$ :ол!те все!илостввато и всешедрего человњко-
любьчв Еогв избввити мя от всякого злв.

Their increased incidence in thirteenth and fourteenth century vitae offers further evidence of the incursion of poetic style into hagiography.

Many of Epifanij's most unusual neologisms are formed by the compression of a phrase containing a noun in an oblique case into a word with a nominal first elesent, such as segsludavec', 'giver of understanding', goroplennyj, volkoxiăčnyj, płenicedatel', kueirotrabnyj,

28. 'Nekotoryje zadači', p. 140.

29. pp. $73,169$.

30. pp. 68,144 . 
or pesnokrasitel'. They may be compared to extraordinary compositions like zvěroprogonitel' found in the Slavonic Manasses Chronicle. Evtimij's neologisms umovrêdnyj and aggelolěpnyj pale before such inventive profusion, and Domentian does not employ composita with unusual nominal Iirst components at all. The reason for Epifanij's attraction to these composita is probably the ease with which they could be woven into word patterns compared with the phrases from which they were formed, coupled with their concentrated expressiveness and exclusively literary form. The striving of these hagiographers towards greater emotional impact also prompted the use of superlatives compounded in pré-. These are occasionally woven into patterns for added emphasis. Like other composita, they are a common feature of prayers and of biblical language, being applied predominantly to the Trinity, the Virgin Nary or biblical personages. Thus divine wisdom is premudrost' rather than mudrost', and in the Passion and Encomium to Boris and Gleb God is addressed as premilostivyj Gospod'. is a result such superlatives traditionally possess emotional overtones of awe, which are transferred to other objects to which they are applied.

Both Homentian and Epifanij employ them when referring to the Virgin Mary in the conventional language of prayers: Epifanij states that the Permian church built by Stefan is dedicated to the presvjataja, prečistaja, preblagoslovenaja vladyčca, ${ }^{31}$ and the same formula occurs several times in Domentian's vitae though usually with only a couple of epithets, such as prěcistaja, prěblagoslovenaja vladičica. $3:$ vonentian also applies epithets compounded in pré to the subjects of his vitae, an extension of its original application, though not unknown in hagiography. The most unusual feature of their treatment is their incorporation

31. f. $675 \mathrm{v}$.

32. Life of simeon, p. 11. See also pp. $24,34,67$. 
into panegrric vord patterns, as in the Serbe' culogy of Simoon, a passage as rhythmical as alwost any in the Life of Steran of Pern':

- првбогвте блвгодьтир христовор,

и пртслввьнии вь влвдиквхъ земльныхь

у. пртмутьствьни Пемвнг, светоименоввныи богозввнии Симеоне, көко ботомудри доброть твоки почоудимв се?

Emphatic compounds beginning prל-are here placed in similer position in successive phrases to create a rhythmic effect. Their ewotive associations are further reinforced by the inclusion of other composita. Occasionally clusters of these words may appear in narrative, as in the account of witnesses' reactions to Simeon's death:

овя же твлостьно рыданте, друзия же оутвсьно дивеште се и оуюомв грьираютте прввелико прьвеликваго сьитеник.

Here they are combined with prĕ- used as a verbal prefix in a typical example of pletenije slores. Epifanij's stylistic treatment of composita beginning pry- is even more radical. Not only are they applied to the church Stefan built in Perw', an unusual adaptation of their traditional function, but are also woven into a poetic passage with a high point in which Epifanij displays dazzling virtuosity. They are rhythmically arranged in the second part of an antithesis wich asserts the divine source of the beauty of Stefan's church:

не того көди киите человьчьскмии хитростия утворенв, или мөстерскыми коаньии и јмыплении и догвды преухорошенв, но преукрешенв болиею слввою и добродьтели предобрену, и ботествеными слввословии преизиетвнну, и человтчески! спвсениеи преупешрену, и прввослввия льпоток пресдьну (1. 765)

With the exception of predobrenyi, a new gramatical formation and proukrašenyj, every one of these words is a neologise, coined to produce the same effoct on the audience as prayer.

Since Evtimij's concept of hagiography does not drive him to hunt

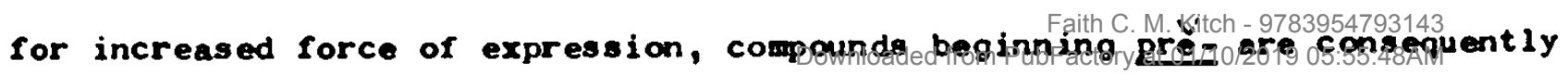


relatively uncomion; usually epithets of a fairly traditional nature,

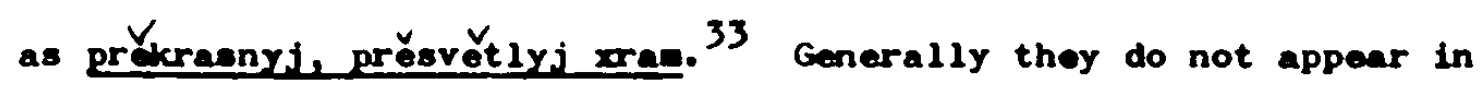
clusters or wen pairs. However numbers of superlatives anding ajéli

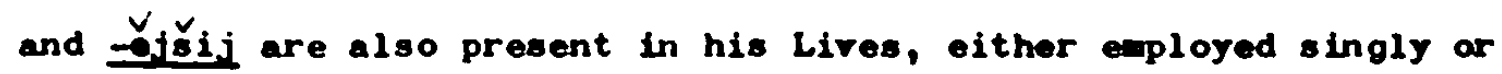
grouped in pairs. These serve the same ends, though they do not conbine so wuccessfully into word patterns, and are consistent with Ertinij's policy of stylistic restraint.

The popularity of certain aroups of composita reflects the literary intentions of the various authors. For exalple, though words beginnting with the negative particle ne- had always been cosmon in ecclesiastical literature, at this period they abound. 34 Indeed they constitute twenty five per cent of the total number of composita in the life of Stefan. Their purpose in ecclesiastical literature was twofold, first to furnish suitable epithets for God and the Trinity since it was felt that man could not talk of God except in terms of what he was not. In hagiography, such epithets are normally found in prayer formulae. In accordance with the tendency towards emotional intensification in vitae written in pletenije sloves, these epithets underwent an expansion varying froa one writer to the next. Not surprisingly, the most daring innovations are in the Life of stefan. 35 Their second function was to assist in conveying the mediaeval Christian Weltanschauung, which viewed the world as a series of opposites. Since words prefixed by the negative particle themselves contained a contrast, they occur frequently in all slavonic Fitae, but nowhere $s 0$ abundantly as in the life of Stefan. This is

33. Life of Petka, p. 65.

34. As V.P. Grigor'ev points out in his article 10 granicax mezdu sovoslozenijem i affiksacijej', Voprasy jazykoznanija, no. 4, Mo, 1956, pp. 38-52, these, like words beginning bez- and even superlatives in pr ${ }^{\gamma}$ - are formally speaking affixed rather than compounded, but as they are employed with a distinct stylistic intention, they have been included here. 
consequent upon the significant role played by contrast in the work. 36 Composita beginning in ne- render brief antitheses more effective, since, used in conjunction with the word in its simple unprefixed form, they demonstrate totality of contrast. At the same time they can be easily slotted into word patterns. Thus Epifanif describes Stefan's position aung the Permians:

\section{сице те убо и сему биня aд от вьрних и от крешених любим и чтом бнвапе, в невнрнии ненввидния его и не qествовапе его и небрегоmв о нем.}

The key words in each part of the antithesis are vêrnyj/nevĕrnyj, each reinforced by rhythmical repetition, in the positive part of the antithesis by two pairs of words, and in the negative part by emphatic enumeration of negative verbs.

The most intricate lyrical patterns involving composita prefixed ne- occur not surprisingly in the Laments, such as in Epifanif's appeal for a more talented writer to revise his inferior work:

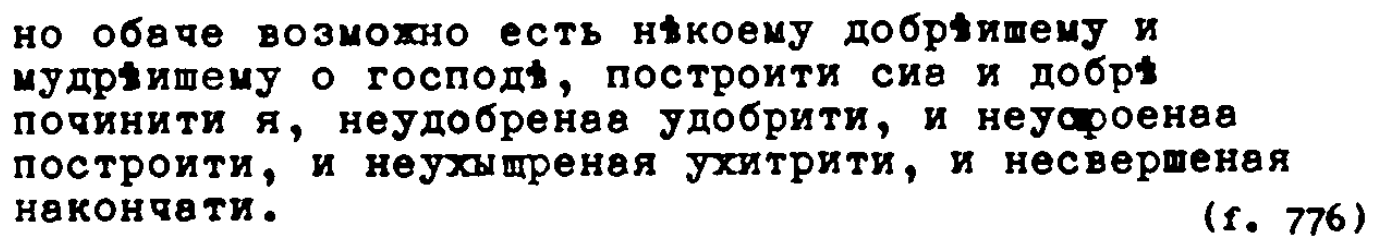
They are also often grouped in pairs like nevěrnyj i nevęglasnyj to add rhythm to the narrative. 37 In this form they may also be part of a passage of alliteration. 38

Just as antithesis is not an important feature of Lomentian's works, so too composita in ne- are relatively rare. But since the style of prayers thoroughly pervades his vitae, prayer formulae which include

36. See pt. II, chap. 4, supra.

37. .766 .

33. See pt. III, chaps. ii,$v$, infra. The alternate method of calquing Greek a- is Slavonic bez-, but such words are much less common (only 6\% of the total numbergofogofylosita

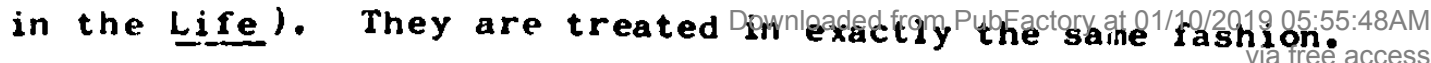


such composita are not uncommon. They also appear occasionally in rhythmic pairs as in Sava's reply to his father's letter:

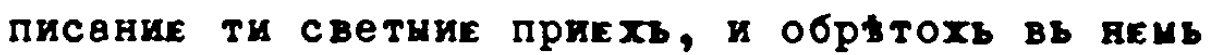
радость ненареченоуо и веселнг неизглаголаног.

Nonetheless they are much less common than in Epifanij's or ivtimij's Lives.

For Evtimij makes frequent but undramatic use of these words, with pairs of prayer origin like sodig neumytnaago i nemilostivyje aggely, 39 or with paronomasia as for example:

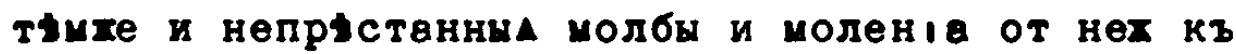
$\begin{array}{ll}\text { богоу непрыстанно приносимы бtзе. } & \text { (р. 80) }\end{array}$

Like all other groups of composita the hallmark of their treatment in his vitae is restraint.

Other forms of compound words are developed by ipifanij alone, to try and convey to his audience the greatness of some aspect of Stefan's work. Thus a series of composita with novo- as first element stresses the pioneer nature of his mission, while at the same time underlining the defencelessness of the young Permian Church deprived of her spiritual leader:

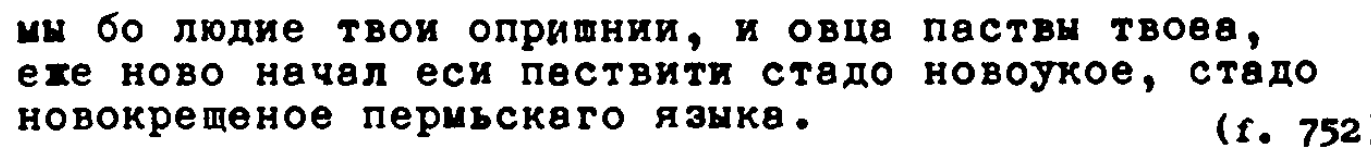

Their effectiveness springs largely from their concentration into a rhetorical pattern.

In comparison with other vitae, a very high proportion of the composita in the Life (about fifty per cent) appear in rhythmical groups ranging from simple to highly complex. At the simple end of the scale stand pairs of words, of which one or both may be compounds. The commonest method of adding a rhythmic touch to prose, the Life of Stefan 
like Evtimij's and Lomentian's vitae furnishes innumerable examples. Many are traditional like ogn' večnyj i negasimijj ${ }^{40}$ or cěl i nebrě̌en, 41 which has its equivalent in Bnglish, safe and sound. Curiously this group is found in two other variants, cĕl i neskrušen and cĕl i nejazven, an illustration of Epifanij's linguistic versatility. 42 when both words are composita and consist of an identical or near identical number of syllables the impact is still greater. So the phrase az mogogrednyj i nerazumyj provides an effective opening to another stage in Epifanij's concluding eulogy of Stefan. 43 similar pairs of composita are extremely common in Domentian's works but less so in Dvtimij's, where generally one of the two is a simple word.

Longer strings of compound epithets also occur in prayers and prayer like passages in the works of all three writers. It is noticeable in the Life of jtefan that these are only applied to the Trinity or other traditional objects of veneration, such as the Last Judgment. 44 similar applications appear in the works of Domentian and Evtimij, for example in the string of compound epithets applied to Christ in the Life of Petka, 4 or God in the Life of simeon, 46 but bomentian (and to a small extent, livtimij) extend the traditional liturgical application to other objects. In Jomentian's case, the explanation lies in his decision to transform his vitae intoextended prayers.

40. . 701 .

41. f. 707 v.

42. ff. $691 \mathrm{v} ., 714 \mathrm{v}$.

43. f. 770 v.

44. f. 676 v.

45. p. 75

46. p. 84.

47. ror a detailed discussion of this type of enuperatienchap. ii infra. 
where Epifanij differs dramatically from the others is in his use of composita in rhythmic passages. These may take various forms: one or other of the components may be repeated, as in this neat antithesis:

\section{прехе били идолослухители и бчсомолци, ту} богомолци явипася.

llere the contrast is emphasized by the retention of the element molec' and the alternation of the rirst, b/so/bogo. In the other thirteen examples of this type, the intention is more often purely rhythmical. The best examples are in the lyrical laments, such as the highly allitera-

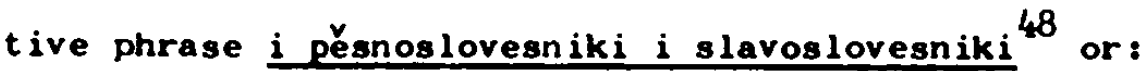

\section{Јви ниь тениве мои добрыи, невыстокраситело и пьснокраситель.

Such examples are rare in Evtimij's works 49 and uncommon in Domentian's, where the best examples are blagyj člověkoljub'če $i$ cušeljub'č and anogoljubor'no $i$ mogomol'bno i mogos l'z'no. 50

Composita are also a common ingredient of Eifanij's paronomasias in which one element of the compound is subjected to repetition that powerfully affects the listener: 51

авконодввцв ли Я тя призову, или законополотникв, имже людеи безаконнни авкон дал еси.

Again Evtimij employs this device very rarely and Uomentian only a little less so. 52 .lternatively, composita may be found in syntactically parailel phrases in which each part is synonymous, as:

aз многогрыпнии в человыных, педостоинын во иноцих.

48. f. 769 .

49. Life of Filoteja, p. 87 , i bogoboaz'ně věštajošti, văš v bogora aumie privlačaase is one of the few such instances.

50. Life of Sava, pp. 125, 192.

51. See pt. III, chap. iv, infra.

52. Life of Simeon, p. 95. 
In phrases such as these, the compound is normally the key word. By its artificial structure and concentrated expressiveness it naturally draws attention to itself. The number of such examples in the life of stefan (more than twenty) cannot be matched by either Domentian or Drtimij. Indeed the whole range of rhythric motifs in which composita appear is peculiar to Epifanij's pletenije sloves. Only the simplest of these, pairs, are as widely used by Evtimij and Domentian as by Epifanij, though Jomentian also displays a liking for enumerative chains of composita, which lend his work the desired air of unreality. Evtimij more often than Epifanij repeats the same compound in close proximity, a less complex and less effective form of pletenije sloves, but consistent with his approach to hagiography. The vast majority of his composita appear outside any form of rhetorical pattern; in Domentian's vitae this percentage is slightly lower and in the Life of Stefan only half occur outside verbal patterns. Many of these comprise part of the traditional vocabulary of ecclesiastical literature, calques like vsesil'nyj from lireek pantocrator or precise theological terms, for which no synonym existed, like blagodat' or dobrodêtel'. 53 They appear in biblical quotations, in conventional phrases like edinorodnyj syn, and above all in prayers. A stylistic feature of prayers, composita were borrowed by these hagiographers to strengthen the solem tone of their work. Thus in the Life of Stefan, their incidence increases in proportion to the emotionalism of the passage: in the narrative there are on average twenty per thousand words. However, in other passages, such as the account of Stefan's early life, where pletenije sloves compensates for lack of biographical detail, there are many wore. 54 When Epifanij discusses the

53. The latter appears fifteen times in the life.

54. An average of nearly thirty per thousand words. 
founding and naming of the Permian church, he first weaves elaborate chythmic patterns to impress the listener with this event, and then clusters composita of a traditional type to help convey the solemity of the occasion. Here there are an average of as wach as fifty five per thousand words. It is only in prayers that the proportion is higher still; in the concluding prayer for the Permian Church there are as many as thirty three in a passage of 440 words, an average of about seventy five per thousand words. The prayer concludes:

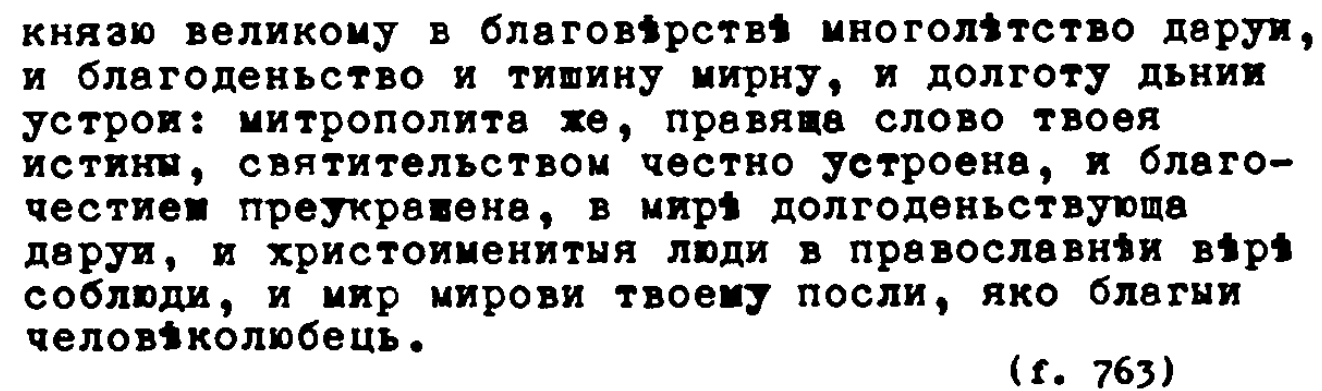

This proportion is much higher than in traditional prayers. Even in the Laments, lyrical tone notwithstanding, there are fewer. 55 It appears that Epifanij was less willing to introduce stylistic innovations into highly traditional prayers than into panegyric. while the Laments abound in rhythm and varied word patterns the dominant stylistic 'innovation' in his prayers is the intensified use of compounds.

As a result of their origins in the language of Christianity, composita possessed both an abstracting and an emotive effect, which were exploited by the hagiographers of pletenije sloves in varying degrees. The power of the compound to abstract the style of the vita from colloquial speech was increased by using them considerably more frequently, Evtimij and Lomentian outdoing Epifanij in this. The emotive effect of composita sprang from their links with the language of worship. Particularly in the liturgy this could be further strengthened by combining 
thew into rhetorical patterns. Epifanij's versatility and astery of his linguistic medium leads him not only to weave intricate patterns with composita, but also to develop the traditional practice of coining new compounds. The startling novelty of some of these when viewed against a background of conventional hagiographical vocabulary, mast be attributed to his restless search for greater impact on the listener. 
CHAPTEK II Dnumeration

The stylistic device of enumeration takes two basic forms: lists of either synonyms or divers related or unrelated objects. Strings of symonyms differ stylistically from enumerated objects, as may be seen by noting that in modern literature the former are wuch less comm than the latter. Whereas modern aesthetic standards tolerate enumeration when it appears essential to meaning, when eaployed as a purely pleonastic device it attracts disapproval. For the modern writer synonyms provide a number of alternatives, which may convey nuances, add a specific stylistic tone or merely halpavoid repetition. Mediaeval hagiographers were not beset by such concerns; since literary etiquette did not frown upon repetition, synonyms were not employed as alternatives but as additions. Lixacev argued that the effect of clusters of synonyms is to eradicate semantic differences between words, drawing out their general meaning. 1 This effect is assisted by the grouping of words of the same grammatical class and formation. This theorymay be tested by a quotation from the Life of Stefan describing the insults Stefan suffered it the hands of the Permians:

много зла пострада от невьрних периян, от некредених, озлобление, роптвние, хухнание, хуление, укорение, уничитение, досвтение, поношение и пвкость.

The horror of Stefan's ordeal is brought home forcibly to the audience and through it his valour emphasized. The list reads easily because of its rhythmic structure, which is provided firstly by identical word endings and brought to a conclusion through a final word of different structure, pakost', and secondly, by the regular dactylic stress of the verbal nouns. But contrary to LixaXev's suggestion, this list of symonyms does not serve to render the exposition abstract. 2 Indeed the reverse is

1. 'Nekotoryje zadaर́i', pp. 120-3.

2. ibid., p. 122 . 
true. For in the narrative section of the Life, Epifanij's main concern is to render the account of events as vivid as possible, and all manner of rhetorical devices are employed to this end. In the passage quoted, the chain of synonyms has two separate effects; the rirst, greater force of expression, the second, an emotional impact induced by rhythmic repetition. It could reasonably be argued that the meaning would have been obscured, abstracted, had the second effect been stronger than the first, but in the event, rhythm merely lightened the long 1 ist of synonyms without destroying the force of the picture of stefan.

Throughout the narration of the mission, groups of synonyms have a primarily emphatic function, though their absorption is frequently assisted by rhythm. So in the depiction of stefan's consecration as bishop of Perm', Epifanij emphatically repudiates suggestions that his promotion was unmerited:

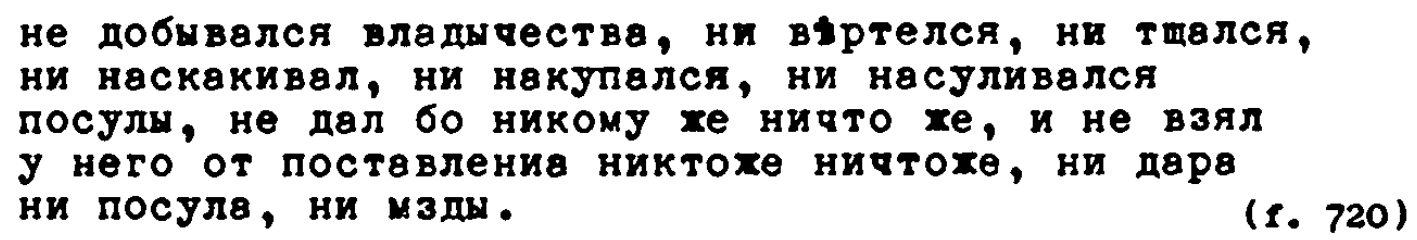
llere emphatic effect is achieved as much through repetition of ne/ ni as through the cluster of symonym, and assimilation is aided by alliteration. But rhythm never usurps the emphatic function of the passage. when Epifanij intends a group of synonyms to have a primarily emotional effect, he heightens its rhythmic qualities. It is possible in such instances to accede to Lixacev's point about the abstracting function of symonyms. Such examples should naturally be sought either in the digressions that counterbalance the vivid description of events or alternatively in the Laments, and indeed pairs of symonyms and highly rhythmical phrases are found more frequently in these sections of the Life. Thus in his discussion of the Permian land before Stefan's mission, Epifanij intensifies the rhythm of a list of synonyms by the simple 
addition of the conjunction $\underline{i}$, and selection as above of rhyming nominal forms with dactylic endings, at the same time grouping his material into two phrases of seven syllables followed by four staccato units of four or five syllables:

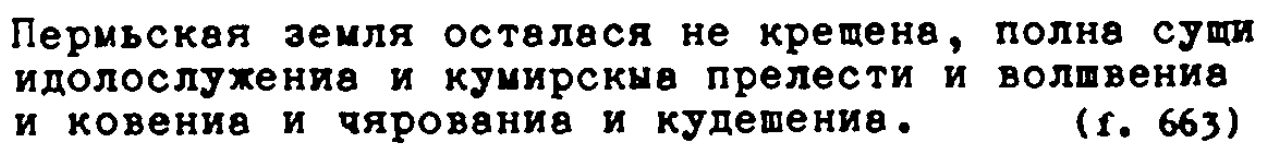
Though emotional effect is increasingly important here, the point of the passage, to declare the idolatry of the Permians, is nonetheless important; first the audience must become aware of Permian paganism before being affected by its horror.

In the Laments, synonyms are employed more for their emotional impact than elsewhere, because of Epifanij's attempts to evoke feelings of sorrow at Stefan's death and reverent exultation at his memory. Praising Stefan he says:

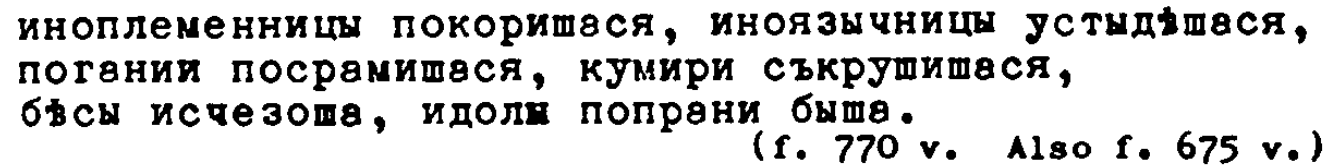
lhe first three phrases assert that stefan humbled the pagans, the next three that their idols were cast down. lhythmic structuring on the other hand runs in pairs; in the first the element ino- begins the first word of each section, and a verbal ending and reflexive pronoun conclude it. rurthermore, the number of syllables in cach part is identical, six and five. In the second pair, the number of syllables is nearly equal, four and five followed by three and five, each unit containing alliteration and both concluding with identical verbal endings and reflexive pronoun. In the final group, the second element in the pair is lengthened to aroid an abrupt conclusion, though the structure of noun followed by verb is upheld. Such rhythmic wealth does not appear in the narrative part of the Life. Even pairs of synonyms and synonynous jhrases, the simulest and most comson form of enumeration, are nore rhythmical when they are 
intended to affect the emotions or abstract the exposition. This is most obvious in the Laments, as for example pesnoslovesniki i slavoslovesniki or vozmjatesja zelo i smutesja velmi, where enumeration and acoustic devices are combined. 5

Nion-synonymous lists on the other hand, whether of nouns, adjectives or verbs are treated in mediaeval literature much as today. In the Life of Stefan, however, their overall incidence is far higher than is acceptable to modern tastes. Like groups of synonym their stylistic function is distinguished by polyvalency, or variety of effect according to context, 4 but their composition allows for certain differences of emphasis. Like synonyms, enumerated nouns may have either a basically emotional or emphatic impact, but the insistent rhythmic beat of synonyms is 1 ess easy to imitate when the sense is different. Hence they are more frequent in the narrative than in the abstract sections of the Life. Furthermore, they evoke a greater range of reactions than symonyms.

Epifanij breaks off his discussion of Stefan's ambition of converting the Permians to explain to his audience the exact whereabouts of this exotic land. First he enumerates the seventeen tribes who dwell on the borders of Perm', then names four rivers that traverse it and finally explains how to get there. 5 Doubtless aware that such abundant geographical detail might prove wearisome, he facilitates its absorption by a rhythmic arrangenent which does not sacrifice meaning; the tribes whose names end in jane (Uvinjane, Ust'južane for example) are linked together. 'The effect of the passage is to lend Perm' a reality in the minds of Epifanij's Russian audience. Had he wished the hypnotic effect of the

3. If. $769,735 \mathrm{v}$.

4. For explanation of the term and examples see 5 . Ullann, Style in the French novel, Oxford, 1964, pp. 7-9.

5. fr. 659 v. -660 . 
rhythm to predominate, he would have been obliged to omit entirely those names which did not conform to the pattern (Lop', Korella for example). A similar process is to be observed in his elaborate dating of events. Following the method of the chronicles, he furnishes the names of secular and ecclesiastical rulers to establish the date of the conversion of the Pussians and Permians respectively. 6 In each case six names are mentioned. This not only adds a note of solemity and precision, but also subtly places the conversion of the Permians on the same level as that of the Pussians by the use of an identical number of rulers in each 1 ist.

In line with the progressively stronger note of solemity in the Life, the date of Stefan's death which concludes the narrative is established by weans of an amazing list of no less than twenty five rulers and Church dignitaries. In this way, Epifanij implies that this event is of far more than local significance.

Many other examples of enumeration in the narrative reveal Epifanij's skill at applying it to emphasize Stefan's virtues and good deeds. Uthers serve to heighten the many contrasts upon which the account of the mission is structured. In the following example, the materialistic religion of the Permians, symbolised by their richly appointed sanctuaries is contrasted with the superior spirituality of stefan, who in destroying them spurns materialism in any form of religion:

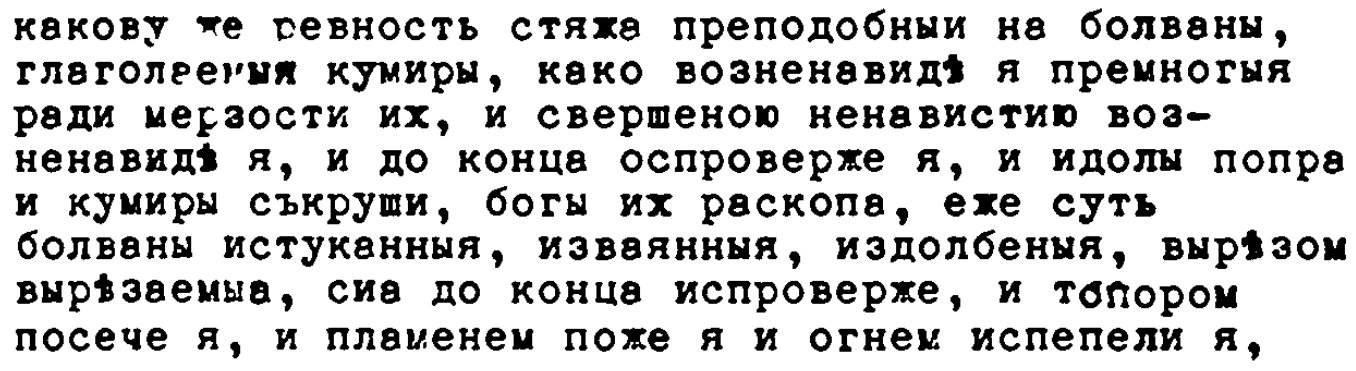

6. $\mathrm{f} .732$ v. $733 \mathrm{v}$ 


\begin{abstract}
и без остатка потреби я, сам по льсу обходя без лености с ученикы своими, и по погост ом распнтая, и в домњх изыскуя, и в льсех находя, и в прибеткых обретая, и зды и онды везды изнвхопяя, пондехе вся кумирница их испроврати, и до основанпв их искореняше я, и ни единя хе от них не игбысть. А еже повешаное около идол, или кровля над ними, или на приношение, или на Украшение им принесеное, или соболи, или куницу, или горностаи, или ласици или бобри, или лисицы, или медвыднв, или рнси или блдки, то все собрвв во едину куб, складе, и огнем предасть я.
\end{abstract}

$$
\text { (ff. 689-689 v.) }
$$

The lengthy quotation serves to demonstrate how Epifanij adds force to each stage in his narrative by means of enumeration. Combencing with three aynonymous phrases expressing Stefan's hatred of the idols and four more describing his destruction of them, kpifanij cantinues with a list of adjectives expressing horror of these graven images. Then in a series of triumphant phrases, some of them symonymous, he tells of their total destruction: '(Stefan) chopped them down with an axe, burnt them with flames, turned them to ashes in the fire'. The underlying theme of triumphant admiration of Stefan's zeal also motivates the next enumerated group, describing Stefan's thorough search for the idols. Finally in an excess of scorn at the mistaken beliefs that led the Permians to decorate their sanctuaries with their most precious offeringa, Epifanij lists no less than nine different kinds of furs Stefan found there. The whole passage is at the same time a repudiation of materialism in religion, written in short rhythmical phrases that echo Stefan's energetic attack on paganism.

Once this struggle is over, and Stefan engaged in pastoral cares, Epifanij admits mach more obtrusive rhythm into enumerations, as in the passage telling of Stefan's hospitality to travellers:

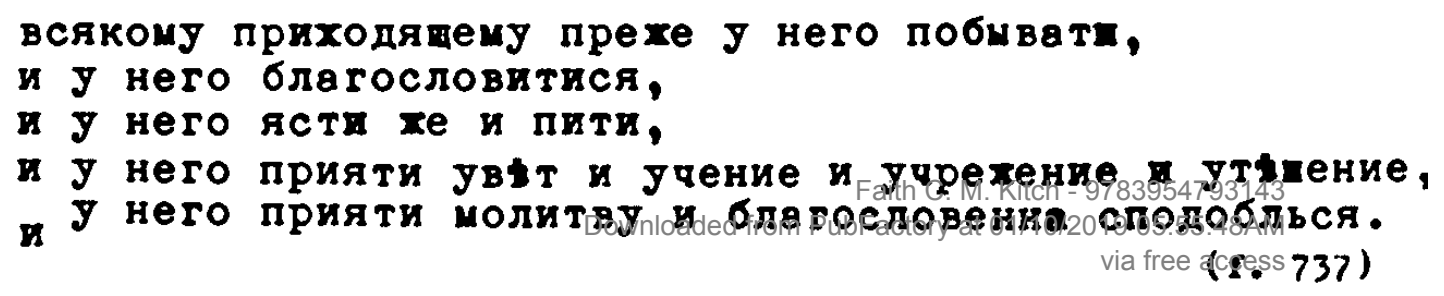


Whythm here is provided chiefly by the alliteration of $u$, which stands at the beginning of four successive clauses, the third of which contains four nouns likewise beginning with the letter . $_{\text {. The emotional climax }}$ of the sentence centres on this group of nouns, the last three of which have identical dactylic endings; the tension then dies away in the concluding clause, allowing a return to the narrative, the next stage of which, describing Stefan's death, follows on immediately. Epifanij's intention is to ensure his audience's appreciation of Stefan's charity before turning to the next stage in his story.

Though enumeration of non-synonymous words is less common in the prayers and Laments than in the narrative parts of the Life, it too may be employed for exactly the same emotional impact as synonyms, as when Epifanij, praising Stefan, describes his welcome in heaven:

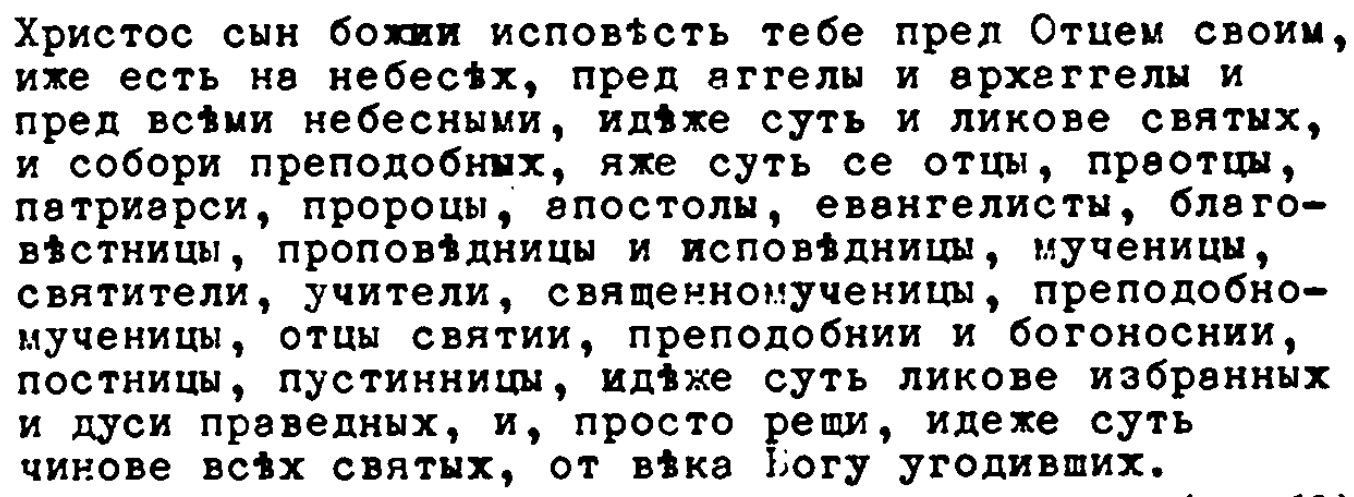

inotional intensity is provided by short sharp rhythms. The list does not furnish information because its contents would be thoroughly familiar to a mediaeval Christian audience, nor does it create a vivid picture. Rather it emphasizes Stefan's welcome in heaven through enumeration of all the heavenly ranks, and in view of its traditional nature would be sure to inspire a mood of solemnity. jince epithets in the vita are almost always evaluative rather than descriptive, strings of epithets in the Life are the only type of nonsynonymous groun to be employed largely in eulogy. Indeed the on ly group 
of epithets with a descriptive as well as enotional impact occurs in the picture of the Permian idols quoted above. All other examples appeal primarily to the emotions. A superb example in the Author's Lament displays fully Epifanij's talent for expanding traditional stylistic formulae and adapting them skilfully. Concluding a passage extolling Stefan in which the question 'what shall I call you' prompts a lengthy series of epithets and explanations, Epifanij then enumerates the titles he feels Stefan has earned:

что еше тя нареку: вохв звблухдьшим, обьтателя погчбшик, наставникв прелщеным, руководителя У!ом осльпленши, чистителя оскверненым, ваыскателя расточенни, страха ратным, Јтыпителя печвлным, кормителя алчющи, подателя требующим, наквавтеля несмисленим, помощника обидимим, молитвеника тепла, ходатав в рна, поганым спвсителя, бьсом проклинателя, кумиром потребителя, идолом попирвтеля, богу слущтеля, мудрости рачителя, Философии любителя, цыломудрия дылателя, правды творителя, книгам сказателя, грамоть пермьстьи списвтеля.

$$
\text { (ff. } 770 \mathrm{v} \cdot-771 \text { ) }
$$

The symmetry of structure in this passage is astonishing; the chain consists of twenty five epithets and modifiers, an initial group of twelve each terminating in dative plural endings in -ym or $-i m$; then in the half way position comes a pair of phrases combrising noun plus adjective (molitvenika tepla, xodataa věrna), and finally a further eleven groups in reverse order of modifier then epithet, each ending in telja. The basic rhythmic arrangement is enhanced by metrical endings, iambic for the initial eight phrases, and dactylic for the rest (the central pair excepted). There is also a tendency to juxtapose phrases where the first element rhymes. This panegyrical topos springs ultimately from the Liturgy of Basil the Great, where it occurs no less than five times though never expanded to this extent. The chiasmus employed by Epifanij may be seen in one of the examples in the Liturgy: 
ти бо еси, Господи, помощь безпонощним, наделда безнаделним, обураемым спаситель, плаваюшим пристанище, недугующим врачь

(Kern, p. 295)

The first two phrases are as rhythaical as Epifanij's, but subsequently much of the rhythmical effoct is lost through the absence of rhyming nominal ondings. Epifanij my not have taken this formula directly from the Liturgy however, since it is also to be found in the panegyric sections of many ritae, for example the Life of Feodosij, ${ }^{7}$ where three phrases are employed, as well as in the Lives of Evtimij and Domentian. Evtimij weaves a string of seven such phrases, but though placing them in the most lyrical of his aulogies, at the conclusion of the life of Petka, they rely for effect on traditional associations rather than strengthened rhythmic arrangement:

ты женвиь слввв, дввамь красотв, впостольскаго 4I!т ге обрезь, поуствнником!в оудобреніе, юнныимь застоупница, соучищи под брекоп!ь хренителницв, вьсекомоу трббовеніх резличнав подетелнинв. (p. 74)

On the other hand, Dowentian exploits to the full the stylistic possibilities afforded by this prayer formula, expanding it to eleven phrases. In conformity with his technique of abstraction it is employed in a eulogy of Simeon by the Serbs which interrupts the narrative. It is not only shorter but also less rhythmical than Epifanij's version:

отьче нешь, богоглвсе Гинеоне, прьдобрыи речителю хр.стовь и крас:телю иврковьныи, :ебесьния чловнче и зөильиыи вньгеле,

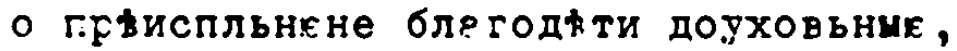
Христово вьселюник, покойте светваго доухв, обители күасьнвю прьсветих и животворештик тройе, щолитпьниче бьдрыи, отьчьствв любьче, ходетею небесьныихь благь ис прьвв благовьстованыихь, доухон! светиинь оть отьие сь небесе послвнниимь...

$$
\text { (p. 37. Also p. } 32 \text { ) }
$$

The exploitation of the enotional associations of prayers in eulogistic parts of Evtimij's, Domentian's and Epifanij's vitae is not limited to 
the above example. Dpifanij's list of celestial ranks springs from a chain of eleven in the Liturgy of John Chrysoeto. 8 Furthermore as may be seen frov Kirill of Turov's lyrical prayars, the expansion of this device is directly related to emotional effect; one of Kirill's prayers, four pages long, consists almost entirely of a string of celestial ranks and individual saints. 9 Dowentian has nearly a dozen examples of this formula in the Life of Sava alone, though none even approaches the arplified rersion in the Life of Stefan, a clear illustration of the diffuse panegyric that characterises his vitae as opposed to Epilanij's high points of emotional intensity.

Negative adjectives are, as already explained, a comen feature of religious poetry, and play a more important stylistic role in the Life of Stefan than in other ritae. ${ }^{10}$ Clusters traditionally appeared in the liturgy as:

безня чальне, нев:дкие, непостихиме, неописвнне,

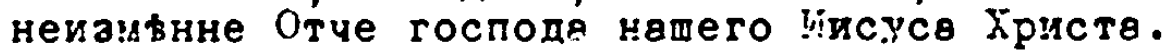

(Kern, p. 214)

In traditional Lashion, Epifanij incorporates such groups into prayers but at the sawe tiwe intensifies the rhytho of the original by excluding alternative forms corpounded in bez-:

и нынь јтверди, Господи, правослевием иерковь свою, юте утверди непреклонну и недвикииЈ, эепотрясому и непокольблену, непозиблему и непосрвину, непорочну и незпзорну, нескверну и непостыдну.

Evtimij and Domentian in accordance with hagiographical practice, similarly employ groups of adjectires but aroid the same intense effect by wingl ing negative and positive epithets. Domentian has a group of ten

8. Kern, p. 291. cf Life of Stefan, $f .768$.

9. Gebete, pp. 338 42. Also pp. $296,328$.

10. See p. 183 supra. 
in the Life of Simeon, ${ }^{11}$ and Evtimij in the lyrical conclusion to the Life of Petka has a string of no less than thirteen, demonstrating that when he deems it necessary he can create poetic ornament as complex as as the others. 12

Other enumerative formulae may actually have originated in vitae. Such is the extended enumeration in which the question 'what shall I call you', repeated a number of times, precedes epithets and explanation. The earliest mention in original Pussian Lives is in the Passion and Encomium to Boris and Gleb, a popular work Epifanij would certainly have known. 13 It is also found in Serbian vitae, notably in Stefan Prvovenčani's Life of Simeon ${ }^{14}$ and in later Hussian words like the Tale of the Life and Death of Dmitrij Ivanovic ${ }^{15}$ where its extensive development is an intermediate step between the version in the Life of Simeon and the Life of Stefan of Perin'. 16 since it is occasionally found in works of other genres like Ilarion's Sermon on Law and Grace ${ }^{17}$ and Paxomij's Service to Kirill of Belozersk, ${ }^{18}$ the attribution to vitae must inevitably be only tentative.

Though eulogistic enumeration may frequently derive from ecclesiastical literature, Epifanij's method of dating through enumeration of

11. Life of Simeon, 11. 84 .

12. p. 75. See also Life of Ilarion, p. 49. Epifanij also has other examples of clusters of adjectives ( $\mathrm{ff} .652 \mathrm{v}$. and $676 \mathrm{v}$.) both in prayers or prayer formulae, but neither are very long.

13. p. 49.

14. p. 5, quoted by sulić in 'srpsko pletenije sloves', p. 121.

15. p. 97. Solov'ev, 'Epifanij Premudryj kak avtor', pp. 93-4, shows how close the passages are.

16. ff. 765 v. -770 v.

17. pp. $107,128$.

13. Luoted by Jablonskij, op. cit., p. 266. 
rulers has no parallel in the hagiography of the Orthodox Slavs. Nor is it a feature of vitae composed in pletenije sloves, since Evtimij does not employ it at all, firstly because the available factual information about the subjects of his vita was very slight, and secondly because according to hagiographical etiquette it was not important to establish facts that did not bear directly on the portrayal of sainthood. Uomentian not surprisingly, does not date the events in Sava's or Simeon's lives since his aim is to divorce them from everyday reality. On the other hand, the date of his own composition of the vitae is recorded but in separate postscripts which list the ruling Byzantine emperor, the ruler of Serbia, the archbishop of Serbia and the abbot of Chilandari. However, as factual details are confined strictly to these sections, they do not relate directly to Domentian's concept of hagiography. It would seem therefore that Epifanij's efforts to render the mission as vivid as possible obliged him to draw on secular literature, in this case the chronicles. That he felt no compunction in so doing is an indication of his lack of training in the rhetoric of hagiography.

One obvious source of enumerative groups previously unmentioned is the Bible, where they are commonly found in the New Testament and historical books of the 01d. Epifanij's list of the tribes inhabiting the regions bordering on Perm' may be compared with a quotation from Isaiah used in the Life:

... The Lord shall set his hand... to recover the remant of his people, which shall be left, from Assyria, and from bigyt, and from Babylon, and from Ethiopia, and from Elam, and from araby, and from eastern sunny climes and froe the islands of the sea. $(I s .11, x i)^{19}$

19. f. 725. Epifanij's version actually alters some of the nawes in the original to ake the passage fit his theme of the spread of Christianity. 
Another biblical list popular in vitae is Paul's enumeration of Christian virtues: 'the fruit of the Spirit is joy, love, peace, longsuffering, gentleness, goodness, faith, meekness, temperance: 20 Epifanij enlarges on Stefan's many virtues, enumerating ten of them and then adds on Paul's similar 1ist. 21 In other vitae the topos is rarely so developed; thus the Life of Methodius has a list of seven, 22 the Life of Feodosij ${ }^{23}$ and Kiprian's Life of Peter still shorter groups. 24 The renewed interest in the saintly individual which led to the revival of hagiography in the thirteenth and fourteenth centuries is reflected in a new emphasis on saintly virtues. Not only Epifanij, but also Evtimij and Domentian develop this enumerative formula. Predictably, Evtimij's lists though common are not as long as their biblical model, consistent with his sense of moderation. 25 On the other hand Domentian's emphasis on Sava's spirituality rather than his biography leads him to weave a supremely inventive string of no less than twenty five virtues. 26

In fact enumeration of all kinds is a major device in Domentian's vitae. lie is fond of incorporating long lists of panegyrical epithets into the text to assist the process of abstraction, but (more surprisingly in view of the underplaying of real life detail in his work) he also enumerates physical objects. However, the same type of list which in the Life of Stefan creates a vivid impression, serves in the Lives of Simeon and Sava to destroy a sense of reality. This is because such

20. Gal. 5, xxii.

21. $1.655 \mathrm{v}$.

22. In Sbornik XII veka, p. 151.

23. pp. 49,54 and 74 .

24. p. 170.

25. pp. 60,64 and 87 .

26. p. 145. 
lists are contained within passages so long and heavily eulogistic in style that the audience is engulfed in rhythm. In this extract describing Sava's return to Athos, only a portion of the sentence is given, but it is sufficient to illustrate Domentian's use of enumeration as part of his abstracting technique:

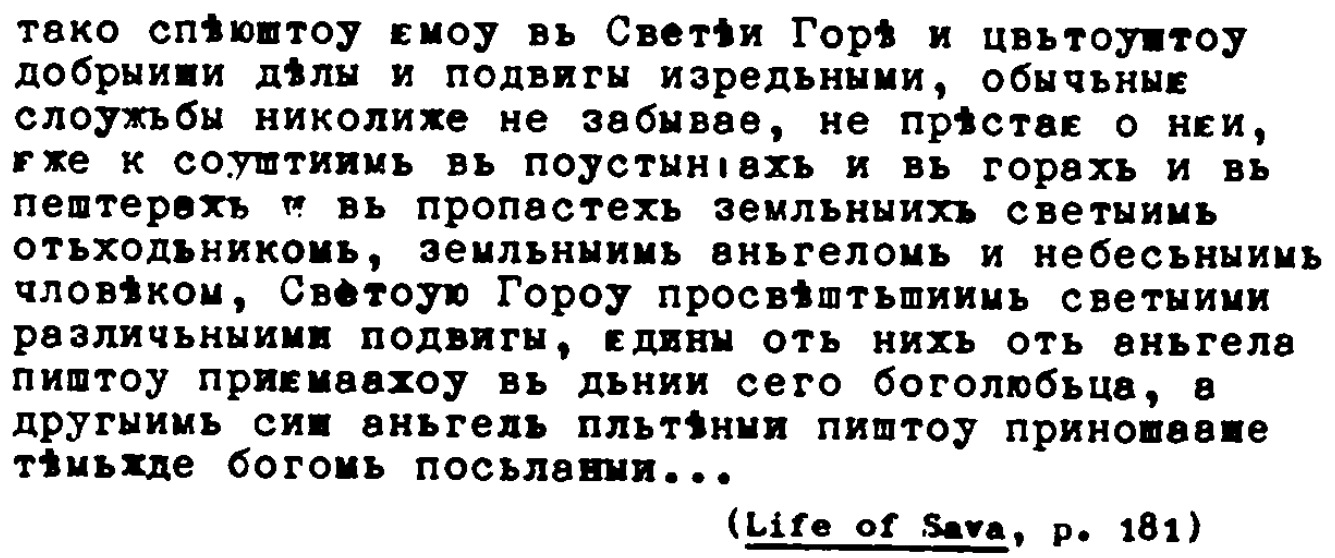

$$
\text { (Life of Seva, p. 181) }
$$

Evtimij on the other hand, like Epifanij uses enumeration for various stylistic purposes. Epithets glorifying the saint are particularly common in the lyrical Life of Petka or concluding eulogies of the other vitae, and are still more frequent in the encomia. Dnumeration is also employed for erphasis as when Filoteja's husband, advocating a life of chastity, lists the horrors of motherhood, with the intention of pointing out that the constant cares and worries of a mother would not perait her to devote herself to God.

Since one of the distinguishing features of pletenije sloves is pleonasm, it is not surprising that all three hagiographers ewploy both kinds of enumerative groups with a greater degree of complexity than was usual in vitae, though not necessarily in other genres. The way it is employed is, like other stylistic devices, dictated by their respective concepts of hagiography. Though enumeration ay either eaphasizo or abstract, Domentian generally exploits anly the latter function. Evtimij and Epifanij share an awareness of both but as in so nany other instances, Epifanij's treatment is much more unusual. Extraordinarily 
long lists of words in the narrative sections stress the reality of events, and in prayers and neditations place the biography in a wider spiritual context, thus heightening the series of contrasts on which the work is constructed. In the non-narrative sections of the Life, enumeration may be so highly rhytheical that the emotional effect of sound upon the audience is of equal if not wore importance than its meaning, whereas in the narrative, rhythm, though more common than in most vitae, only serves to make long lists easy to absorb. 27

27. There are exceptions to this basic distinction between enumeration in narrative and in eulogy, prayers or meditations, as when Epifanij describes with considerable realism the weapons with which the Permians threatened Stefan. This passage is in the Author's Lament not in the main part of the work ( $f .767)$, but such exceptions do not destroy the general stylistic picture. 
CHAPTER III Alliteration

Alliteration is defined by modern literary critics as the identity of individual sounds in adjacent or near adjacent rords, and is eaployed mainly in poetry as a weans of highlighting senentic possibilities or suggesting connections between words. 1 wen the sound qualities that are repeated reinforce the moning of the words themselves, the tere ewployed is onomatopoeia. In mediaeval literature, both definitions and usage were different; alliteration referred to the identity of initial sound or sounds, onomatopoeia to internal identity, and there was no way of describing the process of exhasizing waning or wood through sound. 2 For though onomatopoeia was a poetic derice familiar to the Greeks, Byzantine ecclesiastical literature had largely rejected it long before the conversion of the slavs. Ance it censed to be recognised as armal rhetorical device, its appearance in literature was sporadic and probably partly accidental. The following erapple from Kiprian's LIfe of Peter in which sounds underscore the thewe of the storm at sea, is an isolated example in haglography:

буря бо велия в моря воздвпге ся... волни великн востотдаху

Even in its mediaeval guise of internal identity of sounds, onomatopoeia was far less comon than alliteration. For convenience the two are here analysed under the term alliteration, to avoid the accurate but clumey terw howeoprophoron. 4

1. For discuseion of the role of acoustic devices in poetry, see Richards, op. cit., pp. 103-13.

2. L. Arbusow, Colores rhetorlci, Gottingen, 1948, pp. 76-8. Arbusow deals with rhetoric in ediaeval Vestern Durope, but there is no reason for this not to be true for Orthodor Slar literature..

3. This was the only example of this type in the following vitae: Life of Peter, Vita Constantini. Lis of Sava, Life of Stefan of Perm', Life of Kirill of Belozerak and all four of brtinif's vitae.

4. Arbusow, 10c. cit. 
Alliteration played a secondary stylistic role in early orthodox Slav literatures, since other form of repetition, paronomaia, anaphora and isocolon were all wore striking or served a semantic as well as stylistic end. Alliteration is nost effective when it assists one of these forms of rhythm; elsewhere it tends to unobtrusiveness, as a result of wich it has almost totally escaped attention. 5 Nonetheless, it was regarded as a legitinate stylistic device, as my be seen by noting that whereas examples occur with woderate frequency in Drtimij's vitae as a whole, they are notably lacking in the polenic against heretics in the Life of Ilarion, where they would have hindered the clear exposition of Ilarion's views.

Many examples of alliteration in vitae composed in pletenije sloves are so weak that it is difficult to clain them as deliberate, as: y. того силон невідимох покрввень изиде инвив обрвзонв по срьды стрьгоуштиимв Его воиномв. (Life of Sava, p. 126)

Dowentian way on the one hand have been only dimly aware of rhetorical effect here, or on the other, half conscious of creating a pleasing rhythwic pattern though without aking special efforts. Naturally it is impossible to decide on a writer's intention; two things only way be said with certainty; one, that regardless of intention, sentences are lightened by sound rhythm; second, that any writer conscious of the advantages of alliteration will eploy it sufficiently to ake its deliberate use quite clear. In this he will be hindered only by the limits of his ingenuity

5. Vranska, op. cit., ignored it entirely. Lixačev, Kul'tura Rusi, p. 52, and 'Nekotoryje zadaci', p. 123, notes only that it is a feature of pletenije sloves and, on p. 58 of Kul'tura Rusi gives exayplos under the general heading of word-play in the Life of Stefan. Xižrskij, History, chap. $V$, refers only to sound rhythas in pletenije sloves, and Mulić, 'Srpsko pletenije sloves', p. 127, observes that alliteration in Serbian literature is borrowed from Byzantiun. Mosin, op. cit., p. 89, notes that it is present in the Psalter which exerted a peculiarly strong influence on prose style in Orthodox Slav countries. 
and sense of moderation. Artistic alliteration is the only type that can profitably be analysed, and simple examples such as the quotation above must remain tangential. 6

Forms of alliteration that appear at first glance stylistically neutral may however be tailored to $f$ it the purpose of the individual writer. Thus alliterative phrases which formed part of ecclesiastical terminology, such as božjja blagodat', appear in all manner of vitae, and stem ultimately from the Bible or the liturgy. 7 Generally they are stylistically almost neutral, merely a rhythmic bonus for the writer, but in the Life of Sava Domentian makes a virtue of necessity by employing such phrases together with similar ones of his own (1ike prepodobije i pravda) over and over again as a form of rhythmic leitmotif. Even longer phrases may be used in the same way as when Domentian refers to the hermitages of Athos:

\section{по пустин raxb и по пештерахъ и по пропастехь земльныихь

Far from being an indication of Domentian's poverty of talent, the repetition of simple phrases conforms to the overall policy of abstracting the events of Sava's life. Evtimij and Epifanij on the other hand employ

6. Other examples of alliteration in Evtimij's, Epifanij's and Donentian's vitae that are of little or no stylistic importance are those that occur within the numerous biblical quotations. Had it been obvious that alliteration was a factor in their selection, they would have been deserving of analysis, but this was not the case. Mo $Y_{i n}$ included alliteration in his list of poetic devices in the Psalter (op. cit., p. 89) without observing that alliteration in Hebrew (or Greek) can hardly be expected to coincide with the Slavonic, and that largely speaking, the Slavonic translators are responsible for examples of alliteration in biblical texts, though they may have made efforts at imitation of the Greek version.

7. The phrase božija blagodat' is found for example, in the Life of Feodosij, p. 57; Life of Sava, pp. 138, 168, 169 etc.; Life of Stefan, f. $681 \mathrm{v}$. Alliteration occurs frequently in the Liturgy of John Chrysostom, eg pobednuju pesn' pojusce, vopijušče, Kern, p. 215, which incorporates alliteration and homoeoteleuton. 
such phrases in a highly conventional fashion.

All three use alliteration like other stylistic derices nore intenaively than hagiographers of preceding centuries: wore than in the Vite Constantini for exarple, and slightly wre than in the Life of Feodoeij. 8 At first glance it is ourprising that the diffarence between the Life of Feodosij and Lires witten in pletenife slores whould be so sall, for Nestor's style though elegant, is fairly siaple, but in fact Nestor's alliteration is wch sore unobtrusire, consisting at best of the occasional pair such as na uspex i na ustrofenije, 9 and less than half a dozen instances of dereloped alliteration, such as:

Господь нвшь Иисус Христос плзтир походи и жадвше тамо походити и поклокитпскя им.

Of the three witers, Dowentian reveals the strongest preference for alliteration. Numerical differences are insignificant; the quantity in the Life of Sava only slightly exceeds the nuaber in the Life of Stefan, which in its turn contains slightly wore than Drtisif's ritae, though wany examples in the latter are extremely reak. However, in Doaent ian's ritae alliteration could with some justification be regarded as a mjor stylistic derice, because in the Life of Sara it stands by itself, whereas in the Life of Stefan its function is to assist other rhythaic devices. As a reault, though alliteration plays a larger role in Domentian's pletenije sloves, in the Life of Stefan it is employed with greater subtlety and rariety.

For example the combination of alliteration and enumeration is characteristic only of the Life of Stefan, (Domentian's sole example is quoted

8. Not all vitae of the period employ alliteration core than their predecessors. There are more instances in the Life of Feodosij than either the Life of Kirill or Belozerek or the Life of Peter, though their atyle is no simpler. However Kiprian composes a muber of striking alliterative groups. 
on page 220). Alliteration aids the assimilation of long etringe of words by creating a rhythe that carries the audience through to the end. In this example, a cowon phrase has been lengthened by the addition of another epithet, but the :seavy effect of three compound adjectives or participles is avoided through alliteration:

оставив тльниое се хитие и маловременное, минотекушее и скороивнуюшее.

$$
\text { (fr. } 746 \mathrm{r} \cdot \text { and } 680 \text { ) }
$$

Furthermore alliteration frequently mrke a crescendo, as in Stefan's parting sermon to his people where a rich form of initial sound identity admirably conveys Stefan's concern for the eafety of the Permian Church after he is gone:

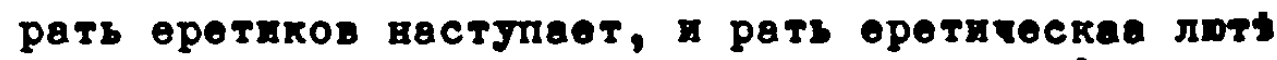

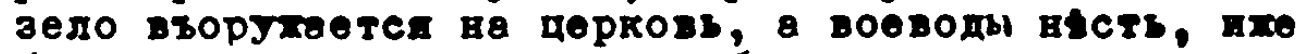

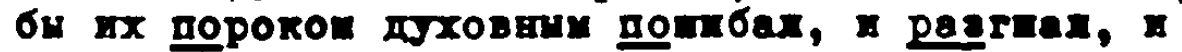
pecropir a paenyins. (1. 755 r.) Similar exanples in Evtimij's vitae, though rare, illustrate his rhetorical talent. In the following quotation from the life of Petka, atring of alliterated words completes a series of rhythmic phrases:

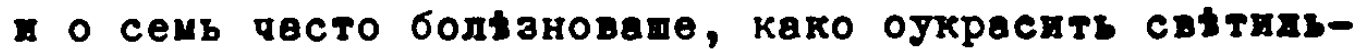
никь, како иасло испльнгть, како сладкаго денгова

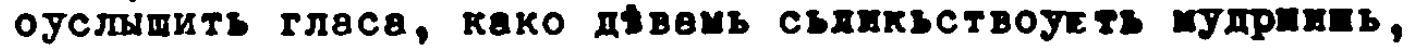

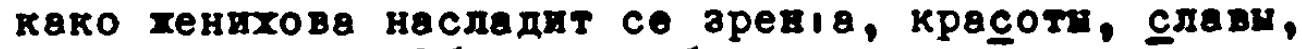
свьтлоста, сьтры бивеніа, блатенства...

The crescendo effect is predictably codulated by placing bla üenstra at the end rather than the three nouns with initial alliteration.

Like enumeration with alliteration, iaccolon is nore often enhanced by alliteration in the Life of Stefan than any other Ita. In the large sections of the life that initate the rhythnic parallel clauses of the liturgy, alliteration occasionally appears as a means of stressing parallelism through sound similarities, as

онд те убо в сластs послJиana jqenne ero, и c paдостир приera nponostis ero, I c rzanuen в posara czobecen ero. 
Alliteration may be joined by auxiliary stylistic devices, such as metre, as in this passage which concludes with a regular alternation of stressed and unstressed syllables:

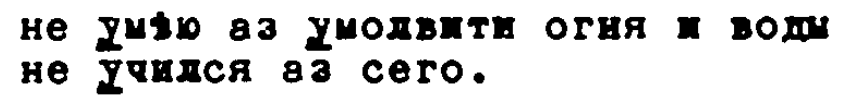

Here the alliteration of initial u connects the two clauses, thus integrating this rare instance of metre into the rest of the sentence. 10 Domentian hardly exploits these stylistic possibilities at all, and there are a mere half dozen examples in Evtimij's four vitae, such as:

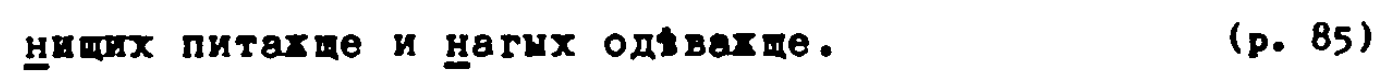

In the same way, any other rhythmic device can be further enriched by alliteration. Examples abound in the Life of Stefan: thus Epifanij talks of the church services in Perm':

четы чтение чтяху перивскор бесьдор, пьвцы те всяко пьние пермвску взаглагодвпе. (f. 721)

In this one phrase isocolon, paronomasia and repetition are enhanced by alliteration of initial sounds. Nothing in Domentian's or Dvtimij's works can match Epifanij's rhythmic richness.

A further type of alliterative group, pairs of words with initial identity of letters, is common to all three writers, for example skorbni i sousčeni in the Life of Stefan, štovaniem' $i$ skrăbijg in the Life of Ilarion, or trudy i tegosti in the Life of Sava. ${ }^{11}$ Arbusow points out that this type of alliteration is also common in mediaeval Western Europe. 12 Domentian, who is singularly attached to lengthy alliterative groups very frequently continues the alliteration beyond the pair as: 13

10. See pt. III, chap. $v$ infra.

11. f. 749 ; p. 33 ; p. 191.

12. op. cit., p. 76 .

13. In 1 out of 3 examples. 
мвль же ч8сь приЕмь и позвань бнсть пр подобьниимь и пйшьम обртте и готовешта се кь зввнйо небесьнвяго отьив...

(Life of Sava, p. 173)

Similar examples occur oniy rarely in the Life of Stefan, Epifanij evidently preferring to combine pairs with other rhythmic devices. In the following example alliterated pairs join repetition, alliteration and enumeration in adding force to Stefan's scornful indictment of the Permian gods :

и тому слукити лучши есть, нетели бвсом пагубным, идолом бездушним, ввпим богом, кумиром глуом, болваном безгласним, истуквнним безсловесни, издолбенним, изваянннм, всякого срама и стлда исполненм, и всякиа скверны двлателем, и всякого зла обрттателем, и всякого грзха творителя. (1. 700 v.)

Parallels in Domentian and Evtimij are few. ${ }^{14}$

Just as differences in the way alliteration is combined with other devices may be observed in the works of the three hagiographers, so too they differ in their treatment of alliteration in consecutive words. Epifanij, who aims for a solem prayer-like rhythm, avoids the staccato effect of consecutive words with initial identity, either by the insertion of $\underline{i}$ (polysyndeton), or by dissipating their effect in a complex stylistic pattern. Thus in his comparison between the poverty of his literary offering to God and the widow's mite, a group of three alliterated words highlights each half of the comparisons

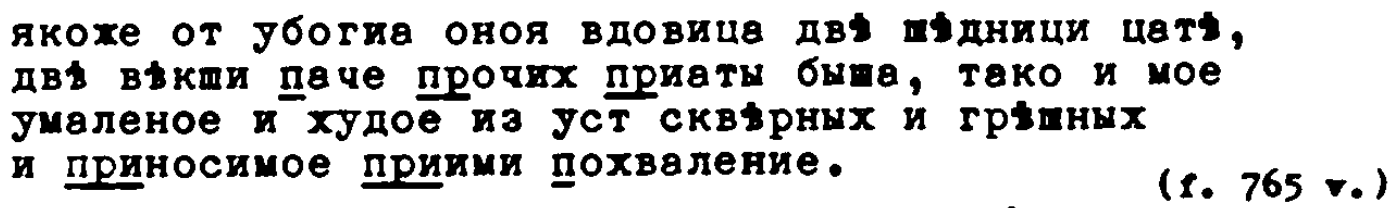

Generally groups of words with the same initial letter in the Life consist of no more than two or three words, like ostaviti otecestro ${ }^{15}$ or

14. For example in the Life of Sava, p. 132, or Life of Filoteja, p. 80. 15. f. 655 . 
paky po pervoje, ${ }^{16}$ whereas Domentian's and Evtimij's vitae furnish numerous examples of strings of four or five. In the latter's Lives these are 1 ess striking than they might be because of the absence of rhythmic structuring. ${ }^{17}$ Their effect is toned down to the extent of placing the first part of the alliteration at the end of one clause, and the second at the beginning of the next:

$$
\begin{aligned}
& \text { Иларіов те... сзбдидаеде стадо, сиыры себе } \\
& \begin{array}{ll}
\text { вз всем бретін. } & \text { (p. 30) }
\end{array}
\end{aligned}
$$

Domentian is considerably wore inventive in concentrating words with the same initial letter, as:

и сльзами ботовидьнию очир любьзнь оброси светоую црьковь светавг Савы своего сьликостоівньника, or combining a sequence of different groups:

и ноо мохеть молитве прраведьнавго поспьти вь

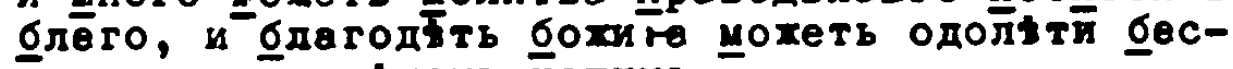
ұисльныиив гртхомь нашимь

(Life of Sara, pp. 214-5)

These two quotations illustrate clearly the differences between Epifanij's and Dowentian's use of alliteration; the former employing it as a secondary stylistic motif, to be incorporated into patterns as a strengthening device, the latter as a primary device, which might stand on its own. In this way, Domentian alters the traditional stylistic function of alliteration.

Purther differences may be observed in the selection of letters for alliteration: the reader of the Life of Savawill not be startled by unconventional alliteration, for most groups involve the repetition of the comonest sounds in Slavonic languages, such as $\underline{b}, \underline{v}, \mathbb{Q}$, po. The most unusual is the combination of $\underline{b}$ and $\underline{v}$, a feature of Evtimij's as vell as Domentian's style, though not found at all in the Life of Stefan:

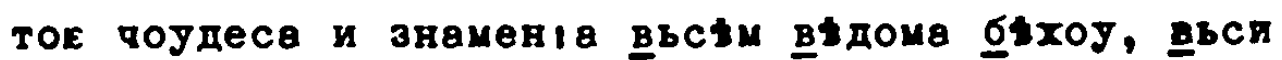
бо ите окрьсть... иситлёнів по̆лоучввхооу,

(Life of Petka, p. 69)

16. f. $720 \mathrm{ve}$

17. See for example, the Life of Ilarior

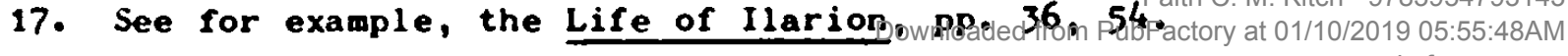


or more effectively:

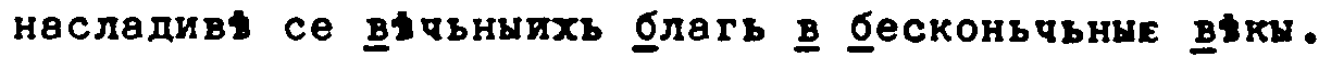

(Life of Sara, p. 178)

The Life of Stefan on the other hand, contains a number of examples of rich and unusual alliteration, as in this description of the burning of the pagan sanctuaries, in wich the repetition of a whole syllable creates a form of internal rhyme:

$$
\begin{aligned}
& \text { куча с куницами, и кумир вкупь с ними...огнем } \\
& \text { сътегаше }
\end{aligned}
$$

This example illustrates clearly the poetic density of Epifanij's style.

If Epifanij expresses a preference for the alliteration of any one sound, then the vowel $\underline{u}$ is undoubtedly the leading candidate, as in: яте о жития его, ова слухон услишах, ова те от

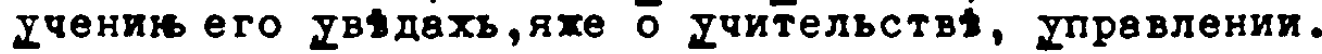

(f. 651)

From this example it is obvious that the repetition of this sound in the Life does not conform to modern definitions of onomatopoeia by contributing to meaning. Most likely, the solem full sound of the back rowel served to intensify the prayer-like tone of the work.

Alliteration is thus yet another traditional device which was intensified in hagiography composed in pletenije sloves. Consistent with their respective approaches to hagiography, Domentian employs alliteration throughout his Lives, whereas Evtimij and Epifanij concentrate it in eulogy and lament. And yet, more than most stylistic devices, it is to be found, though less frequently, in other sections of their vitae. This is perhaps because the unobtrusive rhythm of alliteration makes a subtler contribution to overall rhythmic effect than anaphora, isocolon or paronomasia. Though Domentian makes wch wider use of alliteration than Epifanij, Epifanij's skill at interweaving poetic devices in lyrical passanes is unequalled.

18. See also Kirill of Turov's prayers, p. 250.

19. See also ff. $657,699,714,718,739 \mathbf{v} .726$ v. Faith C. M. Kitch - 9783954793143 Semnloaded firom Pübactory at 01/10/2019 05:55:48AM 


\section{CHAPTER IV Paronomasia}

By paronomsia or annominatio 'the rhetoric of antiquity understands the bringing together not only of various inflectional forms of the same word and its derivatives but also of words perfectly or approximately homophonous'. 1 Word-play is alien to the inspirational genre of the vita, 2 but the repetition of words of one root forms one of the standard elements of rhythmic style. Like other rhetorical devices, its treatment in the Life of stefan of Pers' has attracted comment. 3 The most dramatic forms of repetition are those which assist the rhythmic orderiny of phrases and clauses, whether by repetition of the opening word (anaphora) or of the auxiliary in rhyming verbal endings (homoeoteleuton). Since both contribute to the rhythmic structuring of clauses, they are best considered together with devices of that type. 4 But there are many other instances of a more subtle weaving of patterns of words in which either the same word repeats or a word and derivatives of it are embroidered into stylistic motifs.

These patterns, like other devices, originate in ecclesiastical literature. And Epifanij is bold in his treatment of paronomasia just as he is daring with other elements of style. Thus Nestor's Lection contains no more than twenty five examples of paronomasia, of which a mere half a dozen are patterns created from words of one root. 5 Ihese testify to Nestor's lack of concern with the possibilities inherent in

1. Curtius, op. cit., p. 278 .

2. The pun on leaves, the bookish leaves with which Epifanij compares himself ( $f .775 \mathrm{v}$.$) , is a rare exception.$

3. For example, 亭iževskij, History, p. 179; Lixačer, 'Nekotoryje zadač $i '$ 'p. 123.

4. See pt. III, chap. v.

5. Of the 25 instances, about half a dozen are examples of anaphora, one is in a biblical quotation, and another couple would appear to be fortuitous and not designed for effect. 
this type of rhytha. And only rarely do they possess a diatinct rhythaic effect, as in the phrase rejek nedug i rajeka jasia wich occurs In a passage that lauds the mrtyred brothers, or in the daecription of Boris and Gleb as childra.e

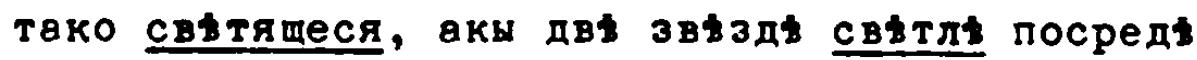
тенных.

Nestor's wderate use of paronomsia is typical of the rhetorical rita prior to pletenije sloves.

Since sowe of the best paronomasia in the lection is found in passages of eulogy, which relate wore closely to the style of prayers than the narrative sections, it was no surprise to discorer that paronomsia is more common in the liturgy ar the prayers of Kirill of Ruror than in the lection, though still a minar stylistic derice except wen occurring in syntactic parallelism, as:

плаввипии сплевай, путешествуоши сшествуй, вдовицам предстани, сирих зашити, пльненуя, избави, недугующыя избави.

(a combination of a quotation from the Liturgy of St. Basil with that of St. John. Kern, pp. 301,294)

Even here, it cannot match Epifanij's ingenuity:

евангелисты блеговыстнищу блөговыстишв,

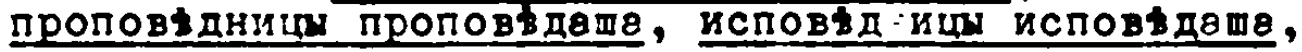

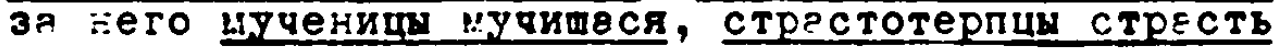
голяше, кровь своп пролжеше, снертв претерпьтв, егоже рвди постниін постишася...

With well over five hundred examples of paronomasia, the Life of Stefan represents a radical departure from accepted stylistic practice both in haglography and ecclesiastical literature as a wole.

Some of the simple parononas ia in the Life exactly reproduces traditional forms such as the antithetical pairs vidigy/nevidigu, tiennyj/ netlonnyj and others like then which occur in the liturgy, and in howiletic as well as hagiographical literature. 7 Another ls the pleonastic

6. p. 25 . 
combination of verb and abstract noun such as vopiju voplen, ${ }^{8}$ subotstryi subotstrovanie ${ }^{9}$ or počitati počitanije. ${ }^{10}$ other pairs of vords of one root like molitva i molenije are not of liturgical origin but appear in works of different periods and provenance. Though found in the Life, they generally provide only a starting point for Epifanij, whose paronomasia reaches new heights of intensity and complexity. For exanple, while the repetition of three words of one root is a commonplace phenomenon in the Life, in other works it is a rarity, and more complex patterns still are unknown.

$$
\text { Epifanij's treatment of paronomasia displays a startling techical }
$$
virtuosity, as when Stefan requests his bishop's blessing on the mission. Here a biblical reminiscence forms the basis for three syntactically parallel clauses in which the three verbs with the same root produce a strong persuasive rhythm while avoiding monotony:

$$
\begin{aligned}
& \text { и молитву сзтвори о инь, да благовыстую в странах, } \\
& \text { и Бог мира да управит путь мои, да исправит стопи } \\
& \text { моя, и направит ногы наша на путв мирев. }
\end{aligned}
$$

Repetition is equally effective in antithesis. Thus the Permian converts triumphantly announce the shaman's defeat at the hands of Stefan:

$$
\begin{aligned}
& \text { тягался есть с тобою словесы, и не утягал, но сам } \\
& \text { Утяган есть, спирался о выры и не эпрьл, но и сам } \\
& \text { препрьн бысть: измогался, да не измогл, но и сам } \\
& \text { побьхен бнсть, и вспду посраилен есть, и всячвскы } \\
& \text { поруган бысть. }
\end{aligned}
$$

These two examples show how the combination of paronomasia and isocolon creates more powerful rhythms. Likewise, it may be combined with enumeration as on page 229, or alliteration as in Epifanij's description of how he collected his material:

8. Kirill of Turov, Gebete, p. 250.

9. Life of Petka, p. 76.

10. Life of Stefan, f. 657 . 
ова слухом јсдмшах, ова те от ученикв его увьдахь, яте О Уषительствы, управления.

Here alliteration of initial $\underline{u}$ links the two roots that are repeated with two other words in a rhythm that confers an added solemity and persuasiveness on a conventional topos.

A particularly striking combination is that of paronomasia involving compound neologisms as pesnoslovesniki i slavoslovesniki or zakonodavec' i zakonopoloznik, in which the chiming effect is achieved through repetition of one of the two roots. ${ }^{11}$ Such examples which enrich traditional rhetoric follow upon Epifanij's search for greater expressiveness. It is this striving that motivates even greater rhythmic intricacy as in the grief-stricken Permians' description of themselves as stado novoukoje, stado novokreščnoje. ${ }^{12}$

The interweaving of rhetorical devices is essential to Epifanij's pletenije sloves, and from an analysis of paronomasia in the life of Stefan it is clear that the most effective instances occur within already rhythmical passages. Thus in the following quotation from the Author's Lament, the effect of the first three repetitions is less than those woven into the fabric of the syntactic parallelisw that follows:

Павля өпостоля всячьски подрахвв, ихе всьи всяк бшв, да вся приобряпет, да вся спасет, по вСя дни страха трьпя 38 свое стаде, за свор церковв, за свою епископию, яко да церкви сзграхение прииметь, От всLX и 38 вся Богу моляся, Богу возлюбив, от Богя возлшблен бисть, Богв почтив о от него почтен бисть, Бога прослвви й от него прослввен бUCTB.

To place Epifanij's paronomasia in its true perspective, it is more accurate to view it as an additional device rendering a rhythmic passage more effective.

11. ff. $769 ; 749$ v.

12. f. 752 . 
In the majority of striking examples of paronomsia in the Life, the word or root repeated is the key concept in the passage. Thus, in the Iinal lament Epifanij seek to praise Stefan through comparison with the ranks of the blessed as:

әаконодввцв ли тя прпәову, пли әаконопологияв, вихе лидем бераконвим авкон дал есп, и не бивпу Ј них законт, Вуру им Јставил еск, и закон

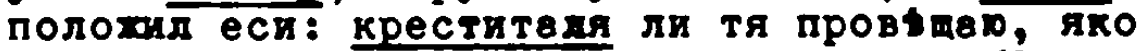
крестил еси лоди иноги, грядудав к тебь на крешение. (ז. 766 )

Each new title (and there are fourteen in al1) is introduced by a rhetorical question, which Epifanij then answers, eaploying where possible words of the same root as the key concept. By repeating words and root rather than substituting synonyms, he further emphasizes Stefan's right to the title, and hence to his inclusion among the ranks of the saints.

In the supreme example of Epifanij's skill with paronomasia, the passage praising Stefan for his invention of the Permian alphabet, the recurring root edin- is not only the key concept, but (an exception to the general rule), also dominates the rhythmic structuring. It is not the repeated ward that is fitted into isocolon, but the syntactical structure that is adapted to $f$ it round paronomasia, and as a result varies according to its demands:

пермьскую хе грамоту един ирьнед слотал, един составил, един сұинил, един көлогер, един мннх, един инок, Стефан глаголю, приснопомними епвскоп, един, в едино время, в не по многв времева и льтв, якоте и они, во един инок, един вьедвнении и Јединяася, един јединенив, един $\mathrm{J}$ единого Бога помоци прося, един единого Богв нв помопь прианвев, един единоиу Богу моляся и глвголя.

( $.730 \vee \cdot)$

13. Parallels to this passage occur in the Life of Sava, pp. 138, 150 and particularly in the Life of Simeon, p. 91. 
The six rhythmic clauses at the beginning comprise edin either followed by verb or noun. Then as the passage reaches a climax, paronomasia is concentrated into the frenzied staccato rhytha of edin v'edinennyj i ujedinjaasja, edin u,jediuennyj, an amazing phrase consisting almost entirely of words of one root. Epifanij concludes with the more measured rhythm of three syntactically parallel clauses. The effectiveness of this insistence on the absence of collaborators on the project depends upon the antithesis in which this passage is embedded, where the key words, many and scarcely, emphasize Epifanij's point that many Greek philosophers over many years scarcely managed to create the Greek alphabet. Thus though rhythm is employed to evoke a devotional response, it is the emphatic powers of paronomasia that dominate the argument as a whole.

The themes that run through the Life of Stefan are occasionally embroidered into complex motifs with paronomasia. In the learned discourse entitled 'O prizvanii i o věrovanii mogyx jazyk', a justification of the mission, the theme of enlightenment dominates through the constant repetition of the root svet.. Paronomasia here has a mild rhythmic effect, which assists the discussion without distracting the attention of the audience. On the other hand, in the Author's Lament the same root appears bound into an intricate emotive pattern; o svêtilniku svêtlo osvěšcenu. ${ }^{14}$ Some other thewe words appear only in a single section of the Life, such as the Lament of the Permian Church which is dominated by three words and their derivatives, plač', vdova and utěsat'. The first, in particular, is a thematic strand binding the structure of the whole section, a plea so heart-felt that prose threatens to give way to incoherent sobs. The lyrical tone is provided as much by other stylistic 
dorices (exclanations, isocolon, rhetorical questions, and enumeration)

as by paronomsin, the watn runction of wich is themetic.

Another stylistic situation mich prompts the repetition ol a key

concept occurs wen a statement to reinfarced by quotations. 15 This

Epifanij begs God for Inspiration to wite, for his ain is to praise Gods

Господи, Јстн мои отвераеши, и јств моя

въЗвњСтят ХвалУ твою: дв исполнятСя ЈСта щоя

похввли, яко да восхввло слвву твою и прилохУ

похвалу твор.

(1. $652 r_{\bullet}$ )

The first part of the extract is a verse from Palm 51 (widely used in services) which introduces embroidering of the basic notion of praise. Here though, the emotive qualities of paronomasia are as important as the purely emphatic. Purely formal effects are upper-wost in several other repetitive passages containing quotations, as:

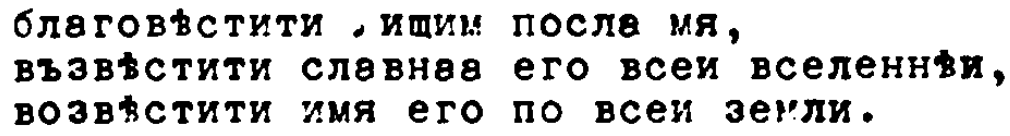

A cunning combination of three quotations, ${ }^{16}$ brought forward by Epifanij in defence of the conversion of the Permians, the passage is intended primarily to sway the emotions through semantic repetition or nearrepetition of the sense of each clause.

Likewise, in the prayers in the Life, repetition has a primarily emotional effect, in spite of the extended paranomasia of theme words; thus the prayer for the Perwian Church which begs God to strengthen her against adversity is permeated by the root tverd-, or the concluding prayer of the Life wich is a triumphant carillon of praises

слввя ти Господи сзтворившеку вся: слввв ти, съвершитель Богу, славв давшему на:! Стефіния, и пакы взеитему, слввв вразумившеку его и уиЈдрив-

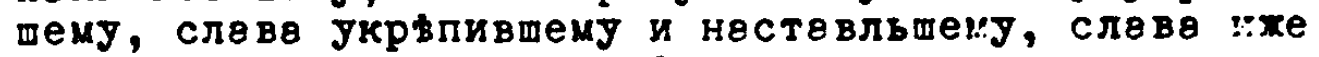
тьм посьтивтеиу, и просвьтивтему землю перивскур

15. An estimated 89 examples of simple repetition together with a couple of dozen words of ane root are comected with quotations. 
слава спасающему род человнчвскии, слава хотянему вся человьки спести в в разуи истинныи привести, слава давтему ии жвот, дв сиа написах. Слава Богу о всых. Слава Отцу и Сину и Святому मуху и нинь у присно и В Вукы Выком, аминь.

(1. 777$)$

The concentration of the repetition of slava with other rhetorical devices and particularly other repetitions lends both prayers their lyrical tone. Nonetheless, the dominant stylistic motif remains paronomasia. Repetition by tradition played a more significant stylistic role than syntactic parallelism and verbal rhyme in prayers, a convention observed in the prayers in the Life. For though there are passages elsewhere which are strikingly intricate, these are deliberately so placed within already ornate passages to elicit a devotional response; thus, while paronomasia is equally common in the laments and the prayers, in the former it is generally subordinated to other more dramatic rhythmic devices. Furthermore, paronomasia in prayers is treated more conventionally; it is usually simple compared with its treatment in the laments. Karely are more than two words of the same root repeated, and the words selected for such treatment form part of traditional vocabulary. To some extent this follows from the content of the prayers, but nevertheless Epifanij appears to have made a determined effort to model the prayers on existing stylistic patterns, though he was obliged to intensify conventional simple paronomasias to strike an appropriate stylistic balance between the prayers and other sections of the Life.

The recurring invocations in prayers, such as utverdi, Gospodi... in the prayer for the Permian Church resemble the refrains occasionally employed by Epifanij to serve the dual function of striking a lyrical note and creating a structural frame. So the householder's question from the parable of the hired labourers 'why stand ye here all the day idle?' 
is repeated to reaind Bpifanij's audience of the biblical authorisation of the calling of peoples to God, and to underacore the pathos of the Permians left till the eleventh hour before receiring the Gospel. 17 Other refrains in the Life are all contained in the parts closest in style to prayers, the Laments. In the final one, the rhetorical question 'shall I call you... ?' dominates the structure of one part, 18 while the sorrowful exclanation 'woe is we' and regret that Stefan's death occurred 'while I was not present' organise another section. 19 All serve as well to convey Epifanij's profound grief.

Whether in refrains or in prayers, in quotations or poetic passages, balancing an antithesis or weighting an eaphasis, repetition in the Life of Stefan is rich, intricate and flexible. Epifanij not nerely borrows frow the poetic genres of ecclesiastical literature, but expands the range and complexity of paronomasia beyond traditional 1 imits. The extent of his innovation emerges even more distinctly from a comparison with Evtimij and Domentian. Vranska scoured Drtimij's ritae and encomia for examples of paronomasia producing a grand total of 525, which at first sight compares favourably with the Life of Stefan, even though the combined length of ritae and encomia exceeds that of Epifanij's mamoth work. 20 But an closer scrut iny, it emerges that she included even those repetitions wich have every appearance of being haphazard. Thus in this quotation from the Encomium to Constant ine and Helena, the recurring nuweral possess no clear stylistic function:

17. For an analysis of Epifanij's treatment of the parable from Matthew 20 , $i-2 v i$, see p. 141 supra.

18. If. 765 v. -772 v.

19. If. $763 v \cdot-765$.

20. op. cit., pp. 17-54. The total in all cases includes anaphoric repetition. 
дв8 на десете ковqегs светимs ојстров впостоломь, златом многомв и каменіемв оукрашен, и шесть оубо от десние полож страни $\mathrm{x}$ mесть от львме. (p. 141, quoted by Vranske, p. 42)

Furthermore a few are listed under two separate headings. As a result of duplication and nechanical thoroughness, the total is artificially high compared with the number in Epifanij's vita, which includes only those repetitions possessing clear rhythmic effect.

Evtimij, as might be expected, increases word repetition in his encomia and those sections of his vitae where lyricism is considered appropriate, such that nearly two thirds of all examples of paronomasia appear in the encomia, and a further high proportion in the oulogies in the Lives. The same trend may be noted in the Life of Stefan where approximately forty per cent of paronomasia occurs in the lanents, which constitute only twenty two per cent of the whole. But there is one curious discrepancy between Evtimij's and Epifanij's paronomasia; the former almost never employs the more subtle patterning of words of one root - Vranska could find only fifteen examples in the vitae, in sharp contrast to the Life of Stefan where they make up nearly fifty per cent of the total.

Domentian, like Epifanij has a liking for the verbal chimes set up by words of the same root: wore than half of the estimated three hundred examples of paronomasia in the Life of Sava involve this type of repetition (an even higher percentage than in the Life of Stefan). Overall, Epifanij leads the other writers of pletenije sloves in the frequency of this traditional rhetorical device in his work, but statistics can throw little light on treatment, for close textual analysis reveals that though many of the same types of repetition found in the Life occur in the Lives of Evtimij and Domentian, development as well as incidence varies from one to the other. Inevitably, both writers use traditional pairs like 
vidimyj/nevidimyj, but whereas Evtimij makes scant use of them, Domentian employs them constantly to emphasize the oneness of all things, the eradication of dividing lines between things temporal and spiritual. Similarly a pleonastic phrase such as blagoslovi blagoslovenijem is avoided by Evtimij but appears more than twenty times in the Life of Sava. The popularity of such phrases is a measure of the diffuseness of Domentian's style set against the relatively controlled rhetoric of Evtimij. If the Life of Stefan contains fewer such phrases, it is because Epifanij is not satisfied with simple traditional formulae. Where it is rare to find wore than two variants of one root in any rhythmic group in Domentian's or Evtimij's vitae, in the Life of Stefan groups of three or more derivatives abound. Evtimij's most unusual combination is perhaps xodatajstruji nexodatajstune $^{21}$ modest indeed when compared with the rich and abundant patterns of the Life of Stefan. Evtimij neither combines different roots into clusters nor enriches paronomasia with rhythmic structuring, though short antitheses with verbal repetition such as the phrase quoted above are both concise and effective.

Domentian's extensive repetition of words with the same root differs from Epifanij's in the conventional vocabulary and higher proportion of traditional simple forms, as in the antithesis: вьмвстивьшина Бога небесемь невьмьстимавг, (Life of Sava, p. 138) as well as in the paucity of complex patterns involving other recurring roots or rhythmic devices. Thus for the Life of Sava, the following rhythmic phrases represent supreme complexity, though by the standards of the Life of Stefan they are unremarkable:

веселием Его обввеселхни бише, и богатвствомь Eто обогаmтени биme. 
In the use of pairs of composita, Dowentian does, however, display a certain originality. There are forty five examples of such pairs in which the first, (or occasionally the second) component repeats, as člověkoljub'če i dǚeljub'čę 22 He may even weave longer strands like mogoljubov'no $i$ mogomol'b'no $i$ nogosl'z'no ${ }^{23}$ or entrine them in repetitive patterns as:

вьси же отьци прыподобввад и првведьнян, светии сьборь прьсветиг богородиде светогорьские, вид-

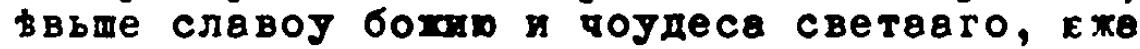
сьтвори богв Cb HIUs.

The artificial character of compounds ake them peculiarly suited to Domentian's hagiographic aims, and the rhythm of Identical compenents further assists the abstract air of the work. In the extended ropetition of svet-above, the intention appears to be to emphasive the otherworldly, saintly qualities of the Athos wonks. It is peculiar to Dowantian's style that the dowinant fenture of this passage is alliteration; whereas in Epifanij's pletenije sloves alliteration is a modest device that may be employed to render his complex paronomaias more effective, in Domentian's prose, repetition of whole words and roots is embedded in a tightly woven mesh of sound repetition. 24

Domentian also differs from Epifanij in the frequency of lengthy chains of personal pronouns repeated throughout a passage, as in the following quotation from Sava's letter to his father begoing permission to remain on Athos:

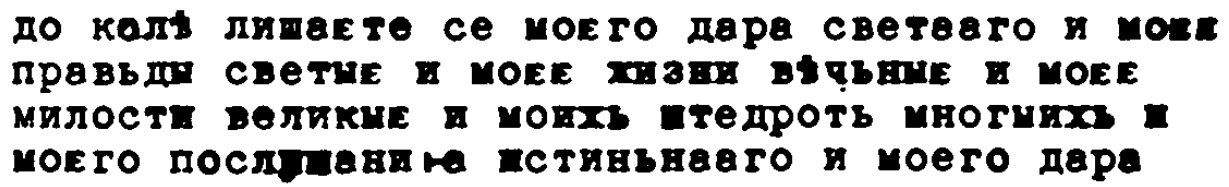

22. Life of Sava, p. 125.

23. ibid, p. 192 .

24. For an excellent example of this process see page 142 of the Life of Sava. See also pt. III, chap. iii supra. 
божьствьнаяг и могто царьствв небесьгвато и

моге славы непрОходимые и дивьнуе и радостннЕ.

(p. 143)

The repetition of the personal pronoun underlines the right of the individual to choose salvation, and creates a rhythmic beat for the enumerated list which is resolved by the final three adjectives, a conclusion reminiscent of Epifanij's pletenije sloves. It is probable that the source for such repetition should be sought in the liturgy, even though Donentian employs it in a different contert. The above quotation from the Life of Sava may be compared with this extract from the Liturgy of Basil the Great:

тебе хвалити, тебе пьти, тебе блвгословити, тебъ кланятися, тебе блатодврити, тебе слввити единвго воистинну сущаго Бога, и тебе приносити сердием сокрУшеннмм...

(Kern, pp. 213-4)

Whereas in Domentian's Life of Sava there are no more than a dozen instances of repetition of more than one word in close proximity, in Epifanij's pletenije sloves instances of extended repetition are legion. Furthermore, a far lower percentage of repetitions are stylistically effective in the Life of Sava than the Life of Stefan, because they either lack a distinct rhythmic arrangement or are lost in an excess of words. Thus refrains rarely make an impact in the Life of Sava, being so far separated from each other as to dissipate their cohesive qualities.

Nonetheless, Domentian's stylistic use of paronomasia bears a much closer similarity to Epifanij's than Evtimij's, and not only because of their mutual fondness for the repetition of words with the same root. Their respective approaches to hagiography involved them in an ornate and artificial rhetoric. Paronomasia is merely one of those devices which undergoes intensive development in the realisation of this aim. 
Even Evtimij employs an enriched form of traditional parononasia; though examples of repetition woven from more than one word are fer, 25 brief, well-composed and effective paronomasias occur more frequently than in earlier vitae. Tius he concludes his description of the whirlwind visit of loan of Rila's brother to the saint's mountain retreat, ending in loan's forcible removal back to 'civilisation':

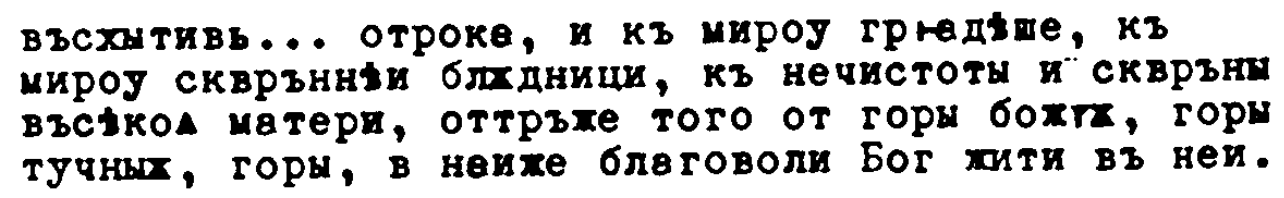

Other vitae cannot furnish examples of such intense and complex paronomasia as hagiography composed in pletenije sloves, but this general conclusion again conceals important differences of intention and technique.

25. For a good example of the repetition of poidi, and $\mathbf{v}$ in one passage see Life of Petka, p. 75. Other striking instances of the repeti$t$ ion of two words or more may be found in the life of loan, pp. 12, 20 ; Life of llarion, pp. $39,45,47,48,36$; Life of Petka, p. 66. 


\section{CHNPTER $v$ Rhytho and rhywe}

Without rhythmic patterning, Epifanij's prose would be turgid indeed, for the pleonastic qualities of the work depend on the sweeping surge of Epifanij's rhythms for easy assimilation. Lixačer, quoting the introduction to the Life of Sergif of Radonez aroued that the intended effect of his style was to open the ears of the lazy, that they wight be nore receptive to the nessage of the work. ${ }^{1}$ Mulic disputed this, suggesting that it had the reverse effect, to stop up the listener's ears, and destroy his sense of concrete reality. This was essential in his orientation towards things spiritual. 2 In fact, it is possible to concur with both views. Pervasive as rhythm is in the Life, its intensity nevertheless varies according to context. Nor is this any accident. When in the central narrative section Epifanij wishes to paint a vivid lifelike picture, such as in the debate and trials of faith, he keeps rhythm at a level which enhances dramatic effect. When he enlarges on the geography of Perm' or establishes the dates of events, he structures his prose just sufficiently to permit the reader to be borne through the mass of repetitive detail. Likewise the biblical parallels to Stefan's debate with the shaman, the refutation of criticisms of Stefan, or the explanation of the evolution of the Greek alphabet, all part of the justification of the mission, are directed towards the intellect rather than the emotions. They are therefore relatively unrhythmical. Strong rhythmic patterns would also destroy the vitality and rerisimilitude of dialogue, and in the speech of the shaman would be frankly inappropriate. He is thus permitted only sufficient rhythm and rhyme to render him a convincing opponent for Stefan, who is allowed to speak in a style closer to the measured rhetoric of the Christian fathers. Yet all these passages are nore

\footnotetext{
1. Lixačer, 'Nekotoryje zadači', p. 125.

2. Mulić, 'Pletenije sloves i hesihazam', pp. 149-50.
} 
rhythmical than is normal in the narrative of vitae. Such rhythm as there is serves to focus the listener's attention, force him to an understanding of the wider significance of the life, to open his ears as Lixačer suggests.

These passages alternate, as has been seen, 3 with lyrical passages of considerable emotional intensity, whether eulogy, prayer or chainlinked biblical quotations. The Life culminates in three laments where torrents of rhythmic phrases have the effect of incantatory prayer, of raising the listener metaphorically from his concrete surroundings into a world of spiritual feeling. Here one must agree with Mulić.

So rhythmical is the language of the life that the question inevitably arises as to whether it is written in verse (in part if not in whole). In recent years redoubled efforts have led to a number of iresh insights into verse systems in early Russia. The result is a number of interesting but often contradictory hypotheses, and a plethora of technical terms which may duplicate or overlap. 4 Scholars express a greater measure of

3. See pt. II, chap. i.

4. The main works on the subject are: K. Jakobson, 'Studies in comparative Slavic metrics', Uxford Slavonic Papers, III, Oxford, 1952, pp. 21-66; also in Selected liritings, IV, The Hague, 1966, pp. 414-63; idem, 'The kernel of complarative Slavic literature', harvard Slavic Studies, I, Cimbridje, Mass., 1953, pp. 1-72, which deals also with the existence of syllabic folk verse in early slav cultures, subsequently lost when weak jers ceased to be pronounced; L. I. Timofejev, Očerki teorii i istorii russkogo stixa, M., 1958, pp. 183-236;

A. V. Pozdnejer, 'Stixoslozenije drevnej russkoj poezii', ScandoSlavica, $\lambda I$, Copenhagen, 1965, pp. 5-24; A. M. Pancenko, Perspektivy issledovanija istorii drevnerusskogo stixotvorstra', TOLL, XX, $N$-L., 1964, pp. 254-73; idem, kusskaja stixotvornaja kul'tura XVII veka, L., 1973, pp. 3-25; N. L. Casparov, 'Oppozicija"stix-proza" i stanovlenije russkogo literaturnogo stixa', Semiotyka i struktura tekstu, ed. M. R. iayenowa, iroc Yaw-warsaw-Gdansk, 1973, pp. 325-36; K. Taranovskij, ' Formy obščslavjanskogo i cerkovnoslavjanskogo stixa $v$ drevnerusskoj literature XI-XIII vv.', American contributions to the VIth Congress of Slavists, The Hague-Paris, 1968, I, pp. 376-94; R. Picchio, 'The isocolic principle in Old kussian prose', Slavic Poetics. Essays in honour of Professor K. Taranovsky, The llague, 1973, pp. 299-31. 
agreesent about folk verse; apart from the unrhyed tonic verse of the sung genres, wost seem agreed on the existence of a spoken (or perhaps intoned) verse, variously termed skazovyj, 5 or skomorosij. 6 This was rhyed and contained a varying number of syllables in each line with two stresses in each half-line. 7 It is widely thought that this type of verse furnished the inspiration for the style of certain literary works, such as the Molenije Daniila Zatočnika and the slovo o pogibeli russkoj zemli. 8 Epifanij's prose likewise makes extensive use of verbal and nowinal rhymes (homoeoteleuton), but in view of mediaeval adherence to the style designated by tradition for a particular genre, it is highly improbable that light-hearted skomorołij verse could have affected the elevated rhetoric of hagiography. The source lies elsewhere.

It is more probable that Epifanij would turn to ecclesiastical verse, especially when it is remembered how frequently he drew on the lyrical style of the liturgy and encomia. But unfortunately there is little agreement among scholars about the type and even existence of such poetry in early Russia. Certainly there was an Old Church Slavonic tradition of syllabic verse composed according to the system of Byzantine 'political' versification, unrhymed but with an emphasis on symoetrical patterns of lines rather than isosyllabism. 9 In the normal course of the development

5. By Jakobson and after him PanXenko and Taranovsky.

6. By Timofejev. The term is employed by others though they disagree about its precise features and extent of its influence on written literature.

7. Timofejev considers that the most emphatic part of the line, usually the verb, was placed at the end of the line. This led to isocolon and homoeoteleuton, (Očerki, pp. 200-2).

8. Pozdnejev describes the form of these works as kondakarnyj verse (see p. 232 infra) and Taranovsky successfully shows that only parts of the work can be ascribed to skazovyj stix.

9. Jakobson, 'Studies in comparative Slavic metrics'; PanCenko, 'Perspektivy', pp. 260-1. 
of Aussian, these verses would no longer have been regarded as syllabic poetry once weak jers were lost. However the conservative tendencies in liturgical pronunciation permitted their retention, and hence also of syllabic verse at least until the end of the twelfth century. And judging from the continuation of the tradition even todny anong certain communities of Old Believers, it mst have survived considerably longer. 10 Nonetheless ecclesiastical syllabic verse did not take root among the Passians, and by the time Epifanij was writing, it is probable that these poems were not regarded as different in composition from other sung ecclesiastical works.

Some scholars further postulate the existence of tonic sung verse, termed kondakarnyi (after the short liturgical hym known as kondak) by Pozdnejev, ${ }^{11}$ and molitvoslovnyj by Taranovsky. ${ }^{12}$ Kondakarnyj stix was unrhymed, possessed a varying number of syllables and stresses within certain numerical limits, and appears to have little in common with Epifanij's rhyming style. Molitvoslovnyj verse is distinguished by the strong rhythmic signal opening the line, usually a vocative or imperative. There is a natural tendency towards anaphora, syntactic parallelism, and homoeoteleuton. This concept has been strongly attacked by Pancenko on the grounds that it evidently is relevant for only a tiny proportion

10. B. A. Uspenskij, ArxaiČeskaja sistema cerkovnoslavjanskogo proimołenija ( $i z$ istorii liturgiceskogo proiznosenija $v$ Rossii, M., 1968; Pancenko, Russkaja stixotvornaja kul'tura, pp. 12-5.

11. The picture is complicated by Pozdnejev's view that kondakarnyj verse, an original Russian developant in ecclesiastical sung verse spread to secular literature, appearing in a number of works such as the Slovo o polku Igoreve, Nolenije Daniila Zatočnika. It seems highly unlikely that a system of versification should pass so quickly, if at all, into genres of a radically different nature from hyms.

12. Conceived of as broader in concept than kondakarnyj, but in fact, because of its structure, considerably more limited. 
of prayers. Furthermore both the vocative and imperative are characteristic of sermons, but Taranovsky doee not consider sermons to be verse. 13 Prayers are wore likely witten in ornate 'poetic' prose. It is perhaps wise to heed Gasparov's plea and cease attenpts to find complete verse systew outside folk poetry in arly Russia. ${ }^{14}$ Once this is accepted then the nature and variety of early Russian rhetorical prose can be analysed properly.

It seems therefore most improbable that Epifanij's hagiographic style may be considered verse when even the inherited forms of Byzantine liturgical poetry were rendered in Russian into a highly poetic prose. It is however, quite valid to examine the types of rhythmic patterning in the Life of Stefan of Perm', comparing them with hagiography as well as other genres of ecclesiastical literature. Picchio in a recent article postulated the existence of a system of prose structuring in early Pussian literature which rests upon an identical or near identical number of stresses in successive cola (phrases or clauses) within one stylistic or logical unit. 15 This isocolic principle, as he terms it, added a rhythmic structure to works intended for reading aloud. Interest ing as Picchio's admittedly tentative conclusions are, there are a number of problems. Surely any literary work in any language intended for reading aloud will tend to be composed in units of a manageable length, especially when the style of many works of early kussian literature rests on repetition and parallelism of various kinda? Picchio notes that even Russian translations of Greek works are subject to the isocolic principle, 16

13. Pančenko, Pusskaja stixotvornaja kul'tura, pp. 15-16.

14. 'Oppozicija "stix-proza"', pp. $325-6$.

15. op. cit., p. $302 \mathrm{ff}$.

16. ibid, pp. 326-7. 
which lends support to the possibility that the same 'systew' may operate in other literatures. Until comparisons are drawn, Picchio's 'system' must remain a hypothesis. But even if a system to wich writers consciously adhered cannot be said to have existed, it seems likely from Picchio's examples that Old Russian prose does fall into patterns of cola with identical numbers of streases. Though ecclesiastical works were probably intoned in an artificial canner that played down stress, ${ }^{17}$ it was not erased entirely and wight still operate as an organising principle. But unfortunately, the isocolic principle is unable to offer an explanation for Epifanij's pletenije sloves, for cola in the Life of Stefan are no more regular than in other works quoted by Picchio, except where it is obvious that other devices such as syntactic parallelism are the main cause of structured ordering of the prose. Therefore, in wy analysis of rhythm in the life of Stefan. I have chosen the rhythmic devices of Byzantine rhetorical prose as categories for analysis. These ares

i. Syntactic parallelism, when the syntax and word order of successive clauses or phrases (cola) is identical or nearly so. Chiasmas, in which the word order in one colon is deliberately reversed in the following one may be considered under the same heading.

ii. Ibmoeoteleuton and anaphora, rhythaic and rhyming signals indicating the opening and conclusion of cola.

iii. Isocolon or stylistic symmetry, attention to the length of successive cola. This does not necessarily mean isosyllabisd but only the restriction of the number of syllables within a certain length to provide a measured rhythm and cause the audience to pause at the end of each section.

iv. Metrical endings to cola, the Byzant ine cursus or any siailar type of patterning. 
Phythw is to be found in short phrases or oroups of worde. Like clauses, these are eubject to considerations of length, word order, acoustic repetition (in alliteration, assonence, paronomasia etc.) and poseibly to metrical treatment. They are therefore scrutinised under the sace four headings. 


\section{i. Syntactic parallelisu}

The arrangesent of words into repetitive parallel clauses is one of the most frequent devices in Epifanif's pletenije sloves; several hundred examples may be found in the Life. Over and over again, chains of syntactically identical clauses create powerful rhythms, each link in the chain tending to be symonywous or nearly synonymous with the others. Through repetition, Epifanij is emphasizing the point he wishes to make, and the wore unified both meaning and structure, the greater the impact of the passage. Syntactic parallelism tends naturally to be static, for it is difficult to turn to another subject or move on to a fresh stage in an argument in the midst of a series of patterned clauses. Epifanif therefore usually employs it as a kind of rhythmic and emotional embroidery to repeat or elaborate on a theme. Because of the incantatory effect of intensive syntactic parallelism, the meaning of individual units tends to be obscured in favour of an overall emotional effect. As a result, the majority of examples in the life are to be found in the Laments. Thus, evoking the reaction of the Permian Church on hearing of the grief of her flock at Stefan's death, Epifanij says:

јслипано же бисть се во ушио иеркви сущав в Перии яко епископв ея престввися, почртиля печаль чад своих, УСлигалв СКорбв людй Своих... (sf. 753-753 v.) Or he himself laments the loss of his teacher:

Увы мнь, кого $к$ риданир моену призову нв помощь, кто ми пособит плакатися,

кто ми слезн утрет, Кто ми плачь Утолит,

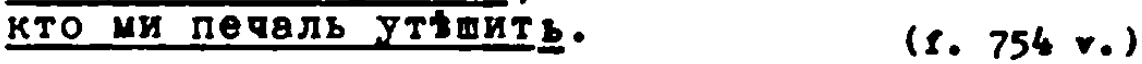

continuing:

усте его не глаголют, в еже излився благодать вданая ему отлетав прочь, глас его умолче, язык его преств глаголати, учение пресякло, источник учение пресяче и ркка прысохла, оскуд поучение в Перми. 
In this last extract the intensity of the beginning is relieved by the inclusion of the phrase a eła... but the pasage builds up to a clieax and concludes with a longer phrase which avoids an abrupt anticlimax. 18

Not all the striking examples of parallelien occur in the laments; in the account of the mission they are aployed like other devices primarily to heighten the dram and bring over the eignificance of events. In euch cases parallel clauses may oven adrance the action. The Tigorous picture of Stefan destroying the Permian idols serves as an excellent example. It ends with a triumphant assertion that there were no repercussions from the affronted gods.

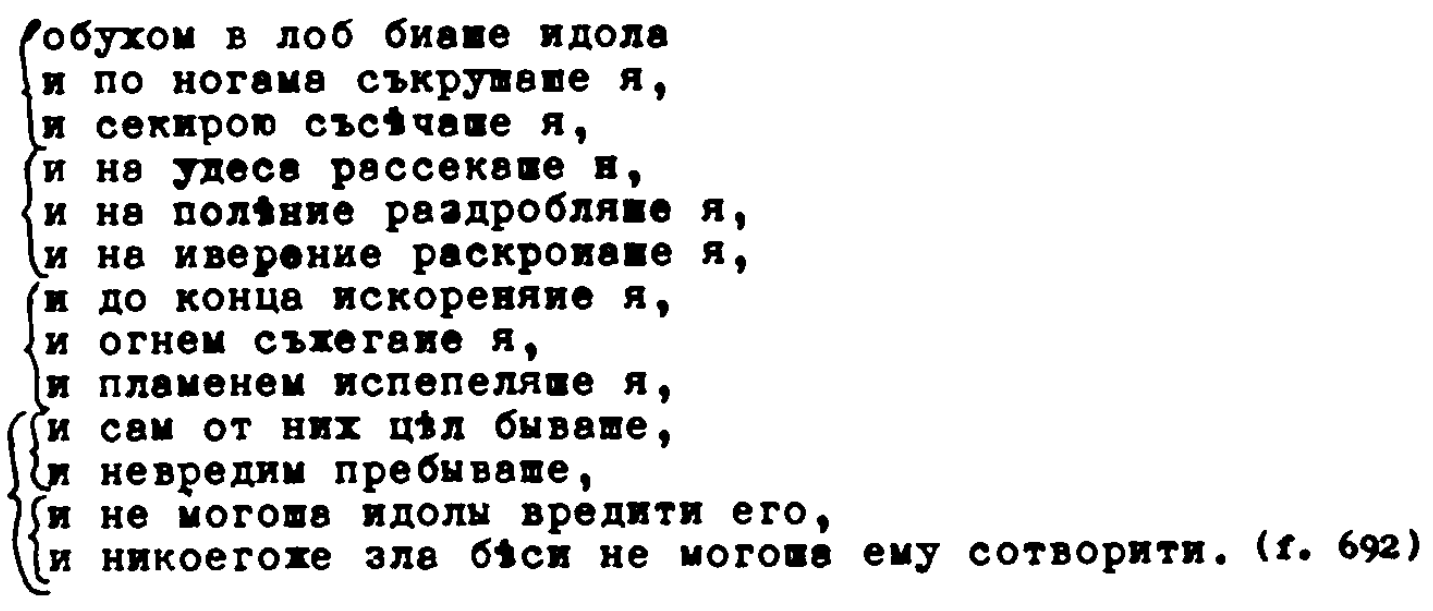

Each stage in the picture, chopping down, hacking into tiny pieces, destruction by fire, is recorded in three parallel clauses. This is then balanced by four more, grouped in pairs, which assert that Stefan emerged unscathed. Both the energy of Stefan's attack and Epifanij's triumphant joy come over strongly. Though the first nine cola are not totally identical in construction, they are sufficiently close to be regarded as parallel. And by grouping them into three groups of three, Epifanij succeeds in the unusual feat of conveying a progressive action in parallel clauses.

18. See p. 243 infra for a more detailed discussion of the ondings of rhythmic units. 
Apart from a semantic grouping of parallel clauses, Epifanij also divides units according to purely formal criteria, as in the final four clauses in the above quotation. There is little difference in weaning, but the first pair is nevertheless constructed differently from the second. Long chains of cola are almost always divided, the formal principle accounting for the majority of examples, especially those in static non-narrative sections of the Life.

It would be unrealistic to expect even Epiranij to extend all syntactically parallel clauses to such lengths. Most examples in the Life contain only two or three elements. Pairs of cola surely reflect the influence of the psalms on ecclesiastical style. The second part of a psalm verse often echoed the first as in: 19

в всю землю ивыдопв вешвнив ит,

и в кония вселенныя глаголы их. (Ps. 19, iv)

a quotation found in the Life of Stefan. 20 As LixaCev points out, in original works of early Russian literature, the symetrical couplet becomes more varied and ornamental, its main developments being either into a string of clauses, or into successive couplets continuing the main theme as: 21

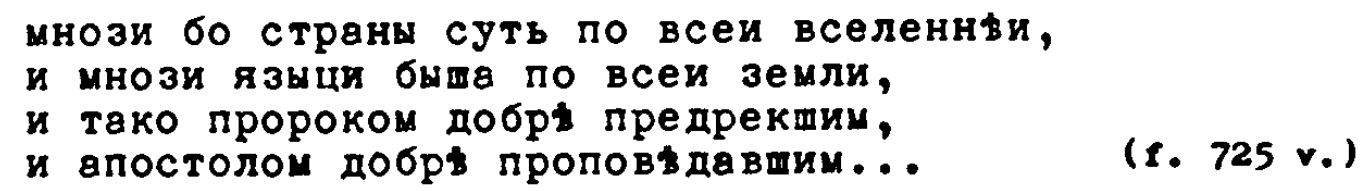
rhus the types of development to be found in the Life conform to the practice of early Hussian ecclesiastical literature.

It would however be unwise to attribute syntactic parallelism in the Life only to biblical poetics, for it was well-known to classical

19. Poetika, p. 168 .

20. I. $660 \mathrm{v}$.

21. Poetika, p. 168. 
rhetoricians. Beloved of the Sophists, it continued to be extremely popular in both Byzant ine prose and verse. Furthermore only a small percentage of psalm verses actually rely on parallel cola. The structure of the psalm verse is based on a symmetrical juxtaposition of two hemistichs, one complementing, enlarging or contradicting the other, but units need not and frequently do not employ the same syntax. Thus a further source is necessary to explain the frequency of identically structured cola in the Life. But while the jopularity of the Psilins madc them a direct fountain-head of stylistic borrowings, the tradition of classical rhetoric was transmitted through the medium of translated ecclesiastical prose and poetry, in which the two traditions were mingled. is a result, it is impossible to decide precisely the extent of its influence, thuugh it was irobably the stronger of the two.

The same may ve suid for chiasmus in the Life. Employed in the bible particularly in the l'salms, and found in quotations in the Lile, 22 chiasmus is a familiar tool of Classical rhetoric. It is relatively rare in the Life irolably because it cannot ie strengthened ly verbal or momin.d $:-4, y: n e$. There are lew perfect exa:riles like:

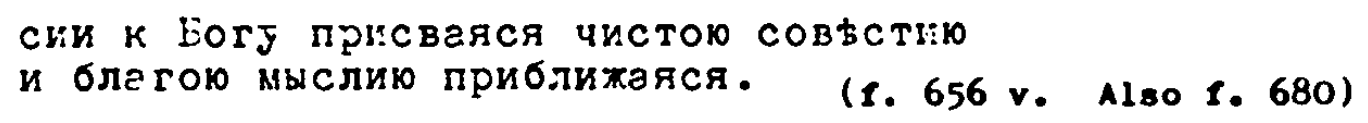
Lpifanij evinces an overwhelming preference for the stronger il:act of sjntactic parallelism.

Where he diverges from the patterns he scts up, he cleirly does so with good reason. In the following eximple the verb in the third clause Xtjaxu has been transposed to create frarononsia:

и попове его перньскнм язнкок служаху обьдню, зеутрени ке и вечерню. пермвскон рьчью пояху,

2.2. See for example, the quotation from Is. $25, v$ on 1.724 . It is not known how ofteil these roflect the str cture of the Hebrew or Greeh oriyinal. 
и конархи его по перивскым книган конархаша, и четцы чтение чтяху пермьскою бесьдою, пьвцы же всяко пьние пермьскы възглаголаша...

(f. 721 )

Other instances are to be explained by the demands of ouphony, which presurably dictated Epifanij's transposition of the verb in the second of the following two clauses:

яко идолослужители в неи сутв, яко деготоп дивволское царствюет в неи. (к. 659)

This flexibility in adapting rhythoic structuring is atched by Epifanij's remarkable ability to incorporate biblical quotations into his patterns:

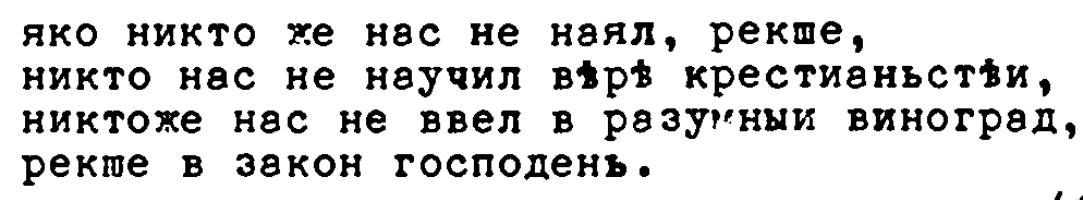
(f. 663 v.)

Here the first unit in the group is drawn frow Matther 20, vii. The other three explain the meaning of the image from the parable of the hired workers, and underline the pathos of the Permians who waited so long to be called to Christianity.

Syntactic parallelisw also effectively highlights antitheses by exposing the vital words of contrast in two clauses in other ways completely identical, as:

к Богу не имам иолитвеника тепла, к человвком же не имам застјпникв скора, (1. 748 v.) or perhaps by threading together a series of like constructed pairs of clauses:

ихе иногда имвх над главою моею свнщу свьтящуся, нынь же свьце угасе ми:

иже иногла имьг скровище сокровено в сосуды глинянњ, ныны же скровище без высти бысть, а сосуд зданныи обрвтеся тощь богатств8 вьрных:

гле иногда праздновах ликоствующи, и радостнотворныя песни поющи,

нын хе рыдалныя и опечаленыя, и плачевныя и надгробныя пьсни. 
Apart from the rich variety of patterned clauses, the Life also abounds in short phrases of identical construction. Their form and function are identical to longer groups, and need not be examined separately. 23

It is noticeable in a number of the examples quoted above, that the structure of the various clauses is not in fact always identical. But provided the rhythm set up is strong enough, none but the grammarian would notice. When syntactic parallelism is reinforced by anaphora, homoeoteleuton or where each unit is of equal length, small deviations of structure are ignored. The aim of parallelism is thus fulfilled.

23. See for example, f. 662 v. 


\section{Anaphora and homoeoteleuton}

Both anaphora and horoeoteleuton are prosodic devices which strengthen the rhythe of consecutive clauses, either by rendering the openings identical (anaphora), or by creating verbal or nouinal rhyoes (homoeoteleuton). 24 Both tend to occur in the wake of syntactic parallelism, but either may be employed as the sole rhythaic device in other types of clauses.

Their origins differ, for while anaphora, like parallelisw owes sowething to both Classical rhetoric and Old Testament poetics, howoeoteleuton sprang from the Classical tradition alone. Examples occurring in Old Testament poetry are probably accidental. In Byzantine ornamental prose on the other hand, rhyming verbal and nominal andings are a common phenowenon. Rhymes of this type are easily created in an inflected language like Greek and were translated without difficulty into Slavonic. But while homoeteleuton is present in equal force in wost ornate prose genres, anaphora is especially pervasive in prayers, where it assists the strong initial rhythmic impulse in each ' 1 ine'. 25

In the Life of Stefan of Perm', both devices are exceptionally common for hagiography. Of the two, anaphora is the more frequent, with over seventy examples testifying to Epifanij's awareness of its powerful rhythmic effect. Not surprisingly, half the examples occur in the lyrical laments, where chains of clauses with anaphoric beginnings succeed each other, interspersed by refrain-like exclamations. In the following example from the Lament of the Permian Church, the refrain of uvy and alternates with clauses beginning either with the word da, or forms of

24. Strictly speaking, nominal rhyes ara homoeooptoton, but for reasons of simplicity, the term homoeoteleuton has been employed to cover all forms of grammatical rhyme, whether verbal, noainal or occasionally adverbial.

25. Taranorskij, op. cit., p. 377 . 
the interrogative pronoun. The passage becomes increasingly rhythmical and concludes in cola of identical structure:

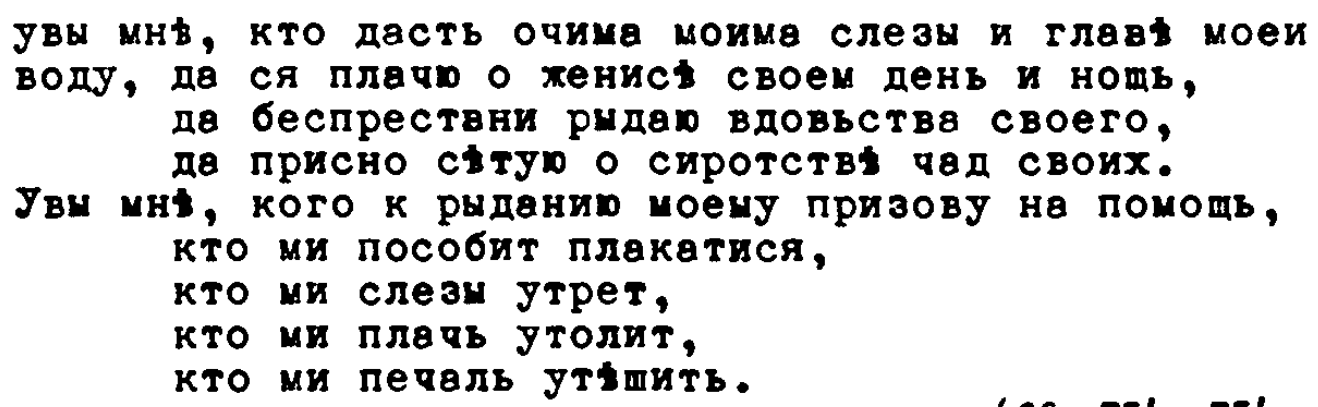

Such passages are strongly reminiscent of the style of prayers, and it is no surprise to discover that anaphora occupies a dominant stylistic position in the prayers in the Life. Thus the phrase, utverdi, Gosyodi starts each fresh sentence in the prayer for the Permian Church, ${ }^{26}$ in a manner strongly reminiscent of the prayer in the Liturgy of Basil the Great, when each sentence begins pomjani, Gospodi. And in the prayer that concludes the work, Epifanij strings together no less than ten phrases beginning slava..slava...

In the main body of the Life anaphora like other devices may be primarily emphatic or emotional. Thus the description of Stefan's dying moments contains a series of anaphoric phrases, each beginning i... followed by another beginning ovomu... These phrases, which fill out the scene by detailing the activities of those present, praying, chanting and so on are rendered harmonious by the use of anaphora which here serves to emphasize the imporiance and solemity of the event. ${ }^{27}$ But like other rhythmical devices, the more intensely anaphora is employed, the more emotive the result. Hence the most striking instances in the central narrative section occur when Epifanij evokes a feeling of awe at, for example, the beautiful church built by stefan, ${ }^{28}$ or his courage

26. $\quad$. 777 .

27. 1. 745. See also the four rhetorical questions concluding the pas-

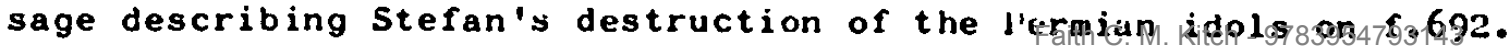


in setting out on his mission:

поиде в землю, идеге не ходива ногама сии святии впостоли, Уचениц господнв. По истинь бо т\$х суть красни ноги, благовьствуощих мир. Повде в земль, идехе не биввли обиходи впостолстии, идехе не изиде вымание и проповддияе святих апостол, идте не бь ни сльда благочестив и богоразуияа, идехе имя ботие отнудь не именовася, идете покланявтся идолом, идыте хрут хертвидв, слугаде глухым кумиром, идтхе молятся издолбенши болваном, идеке выруот в кудесы, и в волхованва и в тарованве, и в бзсованва, и в прочва прелсти дивволскиа, идеге суть глаголвемн иноязичниц невьрния, идыге рекомия невьглвси

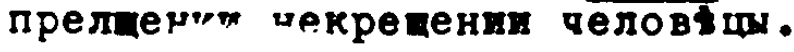

$$
\text { (1. 670) }
$$

There are only three basic ideas here; Stefan's departure, the apostles' neglect of the Permian land, and the closely-related picture of Perm in the thrall of idol-worshippers. And yet from these few points Epifanij weaves a long chain of assertions, building up to the seven clauses

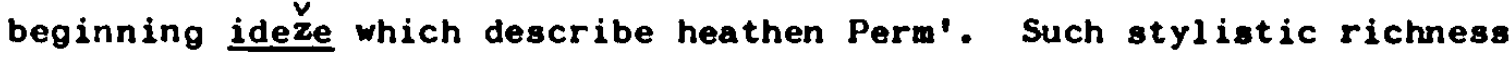
is not found in the body of a vita before pletenije sloves.

Homoeoteleuton is likewise concentrated in the Laments; about half out of a total of more than fifty examples. But even this percentage fails to give a true picture of its extent in the Life, for many instances are exceptionally complex. Thus at the conclusion of a passage asserting Stefan's certain reward in heaven, Epifanij declares:

тебе и Гог грослави, и аггели похвөлиша, и чело-

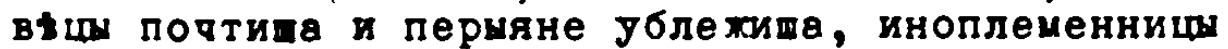
покориввся, иноязичницы устндышася, погания посрамкався, куиири сзкрушишася, быси исчезошв, идоли попрани бнше.

$$
\text { (fr. } 770-770 \vee .)
$$

The phrase tebe i Bog proslavi is a refrain linking the passage to what has gone before, while the intense rhythe of the short clauses successfully ends the passage on a strong lyrical note. It aight further be observed that Epifanif maintains the strongest possible rhythaic drive by grouping the four reflexive verbs together and placing the two 'oddmen-out', (iscezola and poprani bysa), at the end to resolve the rhythm. 
In the example above, most of the units are synonymous. Unison of meaning and structure is lent additional emotional impact by the use of verbal rhyme. In the narrative, on the other hand, when Epifanij's prime concern is emphasis, he employs not synonyms but enumerated 1 ists of details, reinforcing them with verbal rhyme for ease of assimilation:

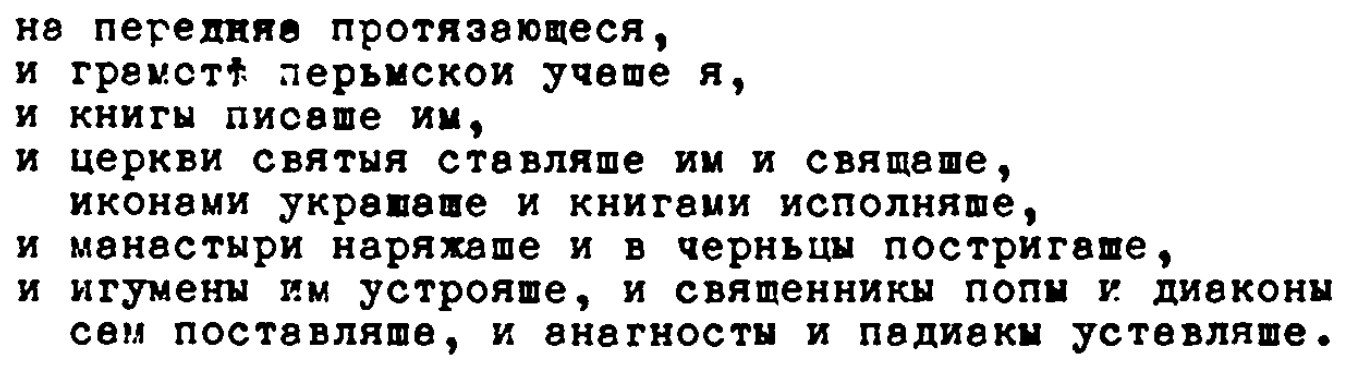
сен поставляше, и анагносты и падияки јстевляше.

(1. 721)

The short clauses and insistent beat of the rhyme underlines Stefan's unceasing missionary activity. Verbal rhyme also appears in the speeches of the shaman as a method of rendering his appeals to the Permians as persuasive as possible, thereby turning him into a worthy opponent of Stefan:

мужи брвтия перьмстии, отечьскых богов не оставливаите, a жертв и треб их не забываите, а старыи пошлины не покидываите, цавныи ввры не пометвите, иже твориша отцы наши...

(f. $695 \mathrm{ve}$ )

From these few examples it is obvious that homoeoteleuton conforms to the general stylistic purpose of much of Epifanij's poetic diction. It is dependent on the essential pleonasm of his style, since it serves to enhance either the rhythm of a series of synonymous clauses and phrases, or of passages of enumeration. Because of this, verbal rhynes frequently reinforce syntactic parallelism. 


\section{iii. Isocolon}

As has been seen, rhythmical clauses in the life are constructed in eymetrical fashion, either repeating the sonse of the proceding clause, elaborating or contradicting it. As a result, they tend to be of similar length. Hebrew pootry, which in a implified fashion conformed to the same rules mkes no etipulation about the number of syllables in any verse or half-rerse. Nonotheless, only a certain amount of variation is poseible within this structure.

The tendency towards isosyllabise is neized upon by Epifanif. Not merely does he reproduce quotations from Pealm likes

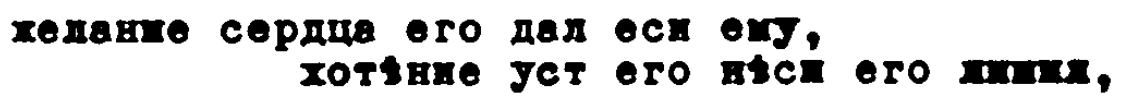

in which each segment contains thirteen syllables, but composes his own

\section{Господь едпв вразушдяпе $\boldsymbol{n}_{\text {, }}$

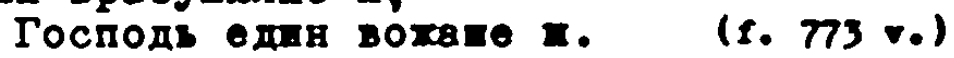

Here one unit of nine syllables is succeeded by another of eight. But just as the use of parallelism, anaphora and honoeoteleuton is intensified in Epifanij's pletenije sloves, so too eymetrical cola appear in long etrings in the Life, rather than in pairs as in the Bible. Such strings are frequently almost identical in length ass

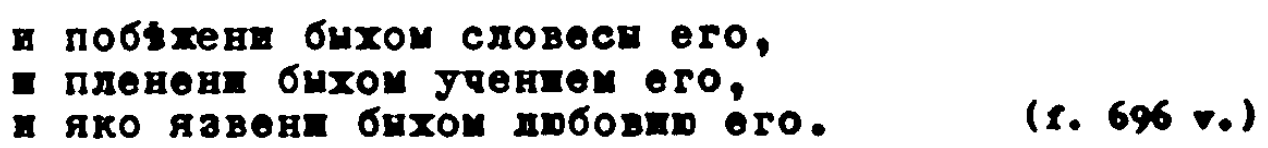

Here the firat two units each contain twelve syllables, the third fourteen. The tendency to make the final unit longer is a general principle of groups of wre than two isocolic clauses in the life. This is essential to avoid the anti-climax of an abrupt break in the rhyth. Often the final unit in the series is the nost eaphatic or sumarisos the meaning of the other units, ass 


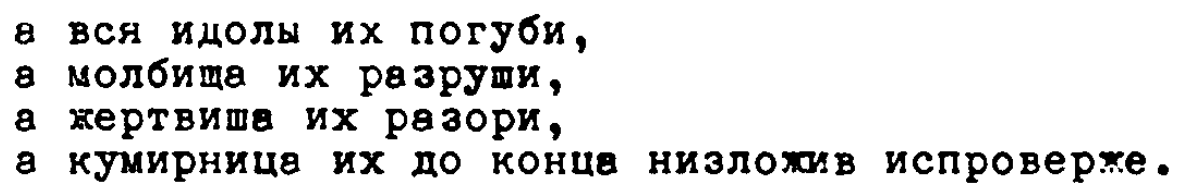

Here the construction is $9+9+8+16$ syllables. 29

As an alternative to this pattern, the length of successive clauses may be extended, as:

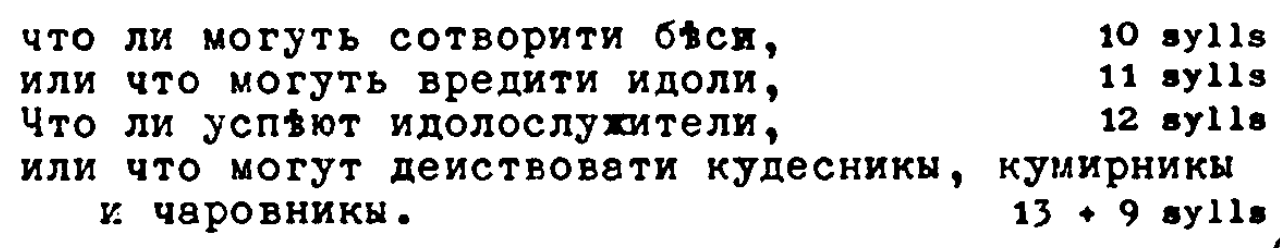
У. чвровникы.

Here the rhythm of the final clause is run on with a group of three foursyllable nouns (a cauda in ricchio's terminology). 30

The above quotations all consist of synonymous clauses, which is typical of the treatment of isocolon in the Life, for when Epifanij wishes to develop narrative or argument, he normally avoicis patterns of this nature. Forceful examples are rare in narrative, and are of two kinds, either where one symmetrical couplet follows another to develop a yeneral theme, as:

$$
\begin{array}{lll}
\text { ( инози бо страны суть по всеи вселеннви, } & 11 \\
\text { (й инози языци быша по всеи земли, } & 12 \\
\text { (и тако пророком добрв предрекшим, } & 13 \\
\text { и апостолом добры проповвдавшим... } & 12 \text { (1. } 725 \text { v.) }
\end{array}
$$

or where a couplet enlarges on the theme outlined in an initial state-

ment, as:

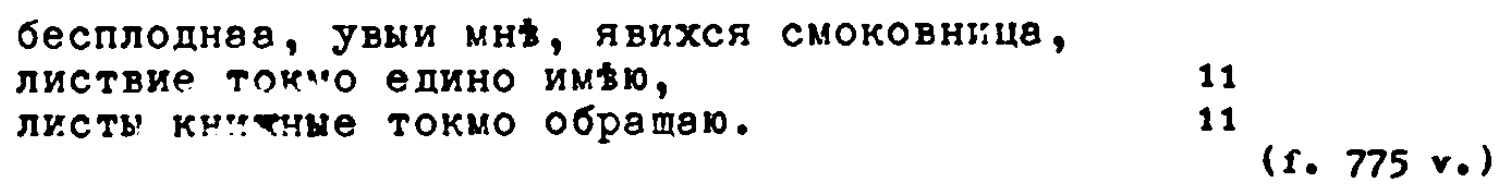

29. For the purposes of counting the number of syllables in each unit, it has been assumed that the i kratkoje of modern kussian had already developed by this staje. Even if conservative factors led to its retention in pronunciation in ecclesiastical texts, this will normally add no more than one syllable to any $l$ ine, and in no way alters the ge:teral conclusions. 
It is a tribute to Epifanij's literary talent that he consistently succeeds in creating varied patterns of 1 ines. The process is to be observed in the myriads of groups of phrases and even single words forming a constant undercurrent of rhythm in the Life. There is a natural tendency for common combinations of words like near and far (bliknyj $i$ dalnyj in the Life ${ }^{31}$ ) to be isosyllabic, but in Epifanij's pletenije sloves this process is considerably extended. He even combines two words in one half of a symmetrical pair to make one part isosyllabic with the other?

от соузи диввольския и от идолослугенив

8 eyllables $\quad+\quad 8$ syllables $\quad(f \cdot 674 \mathrm{r}$ )

or he expands each into a phrase:

\section{спвсителя пјевм нашим и кориителя тьлом нашим}

$$
8 \text { syllables }+i \quad+\quad 8 \text { syllables }\left(1.774 v_{\bullet}\right)
$$

Single words may also be strung together as:

$$
\begin{array}{lll}
\text { еси просвьтил и науяил и обруяил. } & \text { (f. 761) }
\end{array}
$$

However, the shorter the unit, the more probable it is that the number of syllables in each would coincide, and, as a general rule it would seem that other rhythmic devices (such as homoeoteleuton in the quotation above) are of greater importance in creating a rhythmic effect in short phrases.

In spite of the isosyllabism of some of the quotations given here, it should not be thought that Epifanij was writing syllabic poetry. Clearly, he has made an attempt to keep units approximately the same length, but all the examples given are full of other rhythmic devices, parallelism, homoeoteleuton, anaphora and repetition, and these are as important as the number of syllables in a line. The effect of stylistic symetry is highly poetic prose, but it is still prose, though of a rhythmic quality unique in hagiography.

31. f. 743 . 
iv. Cursus and the Life of Stefan of Perm'

It is probable that the system of liturgical pronunciation termed xomonija began to develop in Kievan times but was formalised about the time Epifanij was writing. 32 In this system, weak semi-vowels were vocalised as though strong, thus maintaining artificially the required number of syllables for the chant. 33 Moreover, though texts are usually accented, relatively little weight is given to stress. 34 It is probable that different types of text were intoned differently; special diacritics indicating intonation are found on Gospel rcadings and paremii, 35 and Stoglav indicates a difference between psalm reading and reading of the canons. 36 It is therefore 1 ikely that a broad range of ecclesiastical texts were intoned in mediaeval Russia.

The Life, as a work intended for private reading was not incorporated into Church services. Nevertheless, its poetic style only achieves its full effect when read aloud, and Epifanij probably intended it to be read aloud in extract in monasteries. hould it have been intoned in similar fashion? Judging simply by the frenuent omission of weak semivowels in the sixteenth-century manuscrijt published by uruzinin, the archaic retention of weak jers observed in xomonija was not extencled to hagiography. It is however linely that the manner of reiding hagiographical texts was highly stylised. Even in the eighteenth and early nineteenth centuries poetry was intoned in a manner that played down the differences between stressed and unstressed syllables, ignored akan'je,

32. lispenskij, op. cit. pp. 95-100.

33. ibid., pp. $39-40 ; 62-3$.

34. ibid., p. 39.

35. ibid., p. 25 .

36. Chap. xxvi, cited by Uspenskij, p. 27. 
and shared a number of other features with liturgical pronunciation. 37 There is little connection between eighteenth contury poetry and fourteenth century hagiography, except that both were regarded as written in a high style divorced from colloquial speech. It seems therefore not unreasonable to assume that an ecclesiastical work like the Life of Stefan of Perm' would also have been read in a manner that owed a great deal to liturgical pronunciation, probably in the greater weight given to unstressed syllables, and in a solem measured tone. The style of Epifanij's vita is particularly close to that of prayers, which might further influence monastic readers to chant it. 38

If normal stresses are not given full weight in the reading of the Life, then the effect of isocolon is much greater. Conversely, it might seem that it is vain to search for metrical endings to clauses (the Byzantine system of cursus), if stress was ignored when the work was read. However, though distinctions between stressed and unstressed syllables were weakened, they were not obliterated. The possibility of the existence in Russian rhetorical prose of a borrowed system of cursus cannot therefore be automatically excluded.

Byzantine cursus stood in a direct line of development from incient Greek prose rhythm, which arranged the final syllables of any colon, that is, the syllables immediately preceding a natural pause, into metrical patterns. These cola or clausulae had no fixed number of syllables, and it was only the patterning of long and short syllables in their conclusions that lent them a subtle form of rhythm. These metrical endings were consciously differentiated from poetic metres, and were distinguished by variety and flexibility, which was easier to achieve in Greek

37. ibid., p. 108 .

38. Even if the work were read privately, this effect would still be maintained, because the mediaeval reader probably mouthed the words quietly to himself, much as children do. 
with its long and short syllables than in languages like Russian where usually only one stress is found in each word. 39 The combinations of long and short syllables in the last seven or eight in a colon was so great that monotony was avoided unless the writer concentrated on only a few of these groups. Though Plato,for example, demonstrates an awareness of this form of rhythm by the selection of sume cadences and rejection of others, he nonetheless preserves variety and hence subtlety. Isocrates on the other hand crystallizes a growing tendency towards limiting the variety of cadences, such that his Panegyric, on which he worked for years to enhance its musical qualities, tends to rhythmic monot ony.

Latin writers adapted this system, but as quantity weakened, they replaced it with stress patterns (cursus). it the same $t$ ime, these metrical endings are severely limited in number. In the seventh century the system lapsed in the iest and was only revived in the eleventh when it became an aspect of official style for diplomatic documents and letters from the curia. Treatises explaining its use were composed at this time. 40

Parallel developments may be observed i:ı jygantium where, from the fourth century, accent replaced quantity. Only four forms of cursus are common, but these are not the same as their Lit in counterjarts. They share one feature: the preference for at least two unaccented syllables before the final accented syllable. The most typical metrical cola in Byzantine rhetorical prose employed the following terminal cadences:

39. Some accented languages may have secondary stresses on a word as well, but this is not generally true in Kussian verse.

40. Curtius, op. cit., pp. 149-51; 1. C. Clark, The Cursus in Nediaeval and Vulgar Lat in, Oxford, 1910, 1:2. $15-4$. 


$$
\text { 1. } 2 \text {. }
$$

There is no evidence at all that the Slavs were erer initiated into the wysteries of Greek versification and terminal cadences in prose. It is possible though, that a talented translator aight appreciate the rhythm of cursus and attempt a general form of rhythm in partial imitation. Had this occurred in the early period of Slavonic ecclesiastical literature, the subsequent loss of weak jers would have totally altered the rhythm of cadences and thus destroyed any system that might have been handed down to writers like Epifanij.

The problem is vastly complicated by the lack of knowledge about stress in Old Church Slavonic and Old Pussian. Numbers of texts are 'stressed', but this is not always a guide to pronunciation of the time: thus both Družinin's edition of the Life of Stefan and the version in Makarij's Velikije Čt'i-Minei are stressed, but the stresses by no moans always coincide. However a large proportion do concur with modern Russian usage, which makes study of terminal cadences in the Life a feasible project. Naturally, since stress in Old Hassian must have differed to some extent from modern Russian, some of the examples quoted would have been differently pronounced by Epifanij's contemporaries. Nonetheless, it is assumed that sufficient of them are the same as in modern Pussian to permit general conclusions to stand. 42

41. ibid., pp. $21-2$; also A. H. de Groot, A Handbook of Ant igue Prose Rhythm, Groningen, 1919, p. 135 .

42. For archaic words, reference was made to Dal's Tolkoryj slover' zivogo relikorueakono jevke. 
Analysis of those clauses in the Life which possess a strong rhythm showed that Epifanij, for all his knowledge of Greek, was unacquainted with the four forms of Byzantine cursus. The occasional pattern which appears to follow Byzantine practice is the exception that proves the rule. In the following quotation from the Author's Lament, the third type of Byzantine cursus, two amphibrachs, are isolated among a number of different terminal cadences, in which the dominant feature is one final amphibrach (pot ̌̌čaxsja, svojimi, strĕljaa, desnica). Though Byzantine practice was to avoid the juxtaposition of the same type of cursus in consecutive cola, the existence of only four variations ensured frequent repetition. This is not the case here:

не бо от мудрости, но от грубости сия йзглуӑго́лаัтй акы младенец нвмуя пред ро̆ди́тӗлмй сво̆йй, или акы сльп стрвлеив не, јлучно стрвляв, сице и аз отинудв скйдо̆̈нйи,

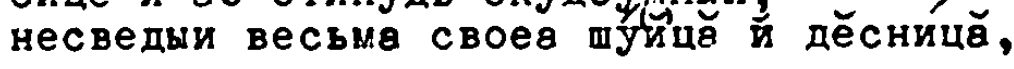
понудих свое невычение...

Since metrical endings vary so considerably, only the same cadence in adjacent clauses will create a rhythmic effect. It is thus no surprise to discover that where terminal cadence is clearly discernible, the same cadence is almost always found in two or more consecutive clauses. This brings prose cursus closer to verse and is consistent with the lyrical tone of the Life. Thus in the example given below the final word in the first pair of cola possesses dactylic stress, while in the second pair the four-syllable final words possess penultimate stress:

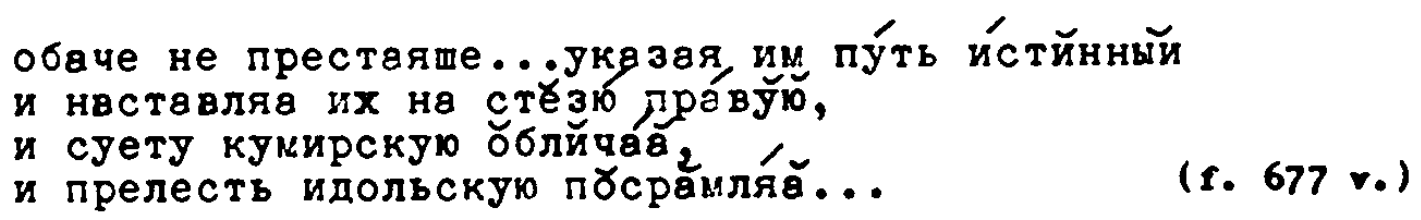

This example is in one way untyuical of Epifanij's terminal cadences;

the first pair of clauses contains a stress immediately preceding the 
final stress in each (pút, istinnnyji, stěezú právüjü). On the whole, Epifanij tries to avoid the juxtaposition of stressed syllables which tends to give a harsh or staccato effect. One of the rare examples may be intentional, as when Stefan begs the Permians :

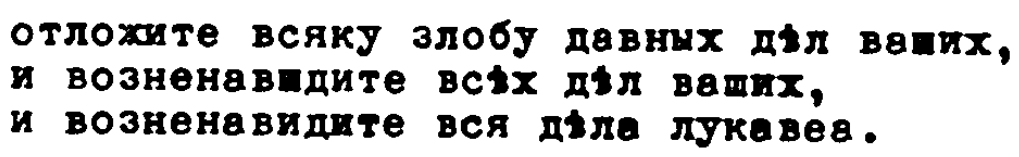

Here Stefan's horror of idolatry is canveyed in the harsh terminal

cadence of the first two clauses.

Nor is it normal in the Life for the cadence to involve more than the final word, which need not possess the same number of syllables as those in other clauses of the oroup, provided the stress is each time on the same syllable numbering from the end of the word. Thus in the following quotation, the stress is consistently placed on the syllable third from the end, though the participles themselves contain either four or five syllables, okajannogo five syllables and grĕgnago three:

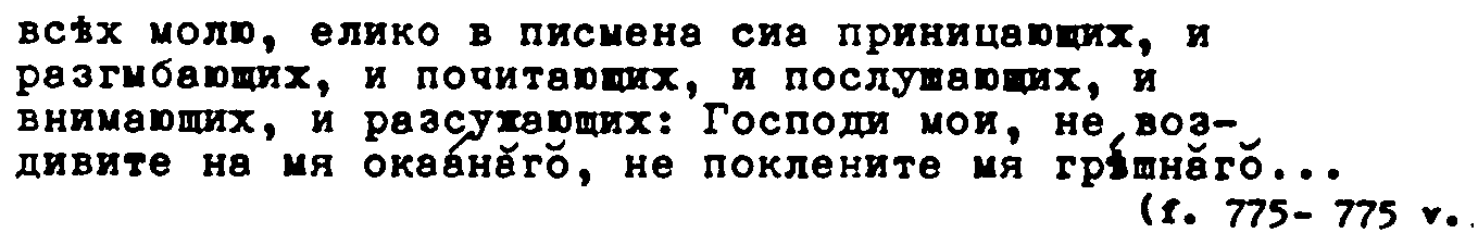

From the instances of terminal cadence already quoted, it is obvious that it occurs mostly in isocolon and syntactic parallelism. When groups of clauses concur in structure and length, the reader or listener becomes aware of a regularity which is enriched by stress patterns. Naturally, in syntactic parallelism, where a word of the same gramatical type stands in the same position in all the cola, there is a greater likelihood of concurrence of stress and number of syllables; for example, present active participles in Pussien are inevitably at least three syllables, and may bear the stress only on some of these. Does this then mean that terminal cadences are largely accidental? Close textual 
analysis shows that this is not so. It surely required a special effort on Epifanij's part to exploy verbs of only one conjugation in the quotation above. However the process of creation was undoubtedly to some extent unconscious; once Epifanij had set up a rhyth for himself, he naturally tended to select those words wich served to waintain it.

For clearly Epifanij had no manual of terminal or any other form of cadence. Only this can explain the variety of types of rhythm; thus in the phrase uspöx ne aud, i polar ne alu, two iabbic feet are followed by the conjunction $\underline{i}$ and two trochees separated by the extra unstressed ne. 43 The slight irregularity in the wetrical pattern suggests that Epifanij was only aware of a general euphony. Further evidence to suggest that Epifanij was aware of the rhythmic effect of alternating stressed and unstressed syllables way be seen in the grouping of identical patterns into symactically parallel passages, as:

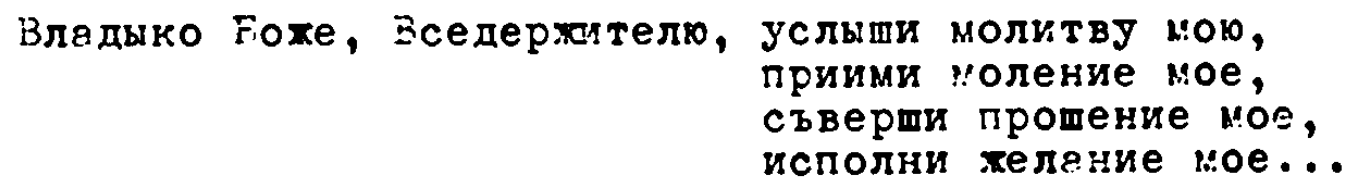
(f. $670 \mathrm{v.})$

Here the first clause is an odd-man out because molitva is not a verbal noun, but the repetition of the same root in the verbal noun of the second clause (molenije) provides a suitable link. Then he could have put either of the other clauses next if he were not interested in metrical patterns. The fact that he chose the clause with absolutely identical stress, leaving the final clause to release the rhythmic tension is indicative of Epifanij's consciousness of the rhythmic possibilities of stress. Were this an isolated example, it would be possible to argue that it was accidental, bat there are mubers of other instances. 44 These

43. f. 650. Assuming stress to be on the same syllables as in wodern Russian.

44. For example, ff. $685 \mathrm{v}, 770 \mathrm{v}, 741 \mathrm{v}$ 
demonstrate a general tendency to resolve the rhythm of the final unit either as above or by increasing the number of syllables in the final unit as propovědnik věry, ispovĕdnik istiny. 45

From these last few examples, it is clear that in certain circumstances, metre appears to cover the whole of a phrase or clause. In every case, this is the result of syntactic parallelism. Hence the patterning of stressed and unstressed syllables is a secondary device, for it occurs in only a small percentage of parallel clauses. Epifanij's primary aim was rhythm through the arrangement and syntactic structure of words in consecutive phrases and clauses, but when this made metrical phrases possible, he took advantage of the opportunity. Thus, though terminal cadence is the commonest type of metre in the Life, cadence may appear anywhere in parallel clauses, whether whole cola, or merely in phrases within longer clauses, as:

от сзу́зы диа́волскпа и от пре́лести и́долскиа. (f. 686)

Tentative as these suggestions must be in view of the absence of solid information about stress in Old Russian, it seems reasonable to assume that Epifanij was aware of the additional rhythm afforded by regular patterns of stress, but unaware of the Byzantine system of cursus.

45. f. 667 . 
v. Rhyme

As a postscript to the analysis of rhyme in the Life of Stefan of Perm', it seems appropriate to add a few lines about a dozen instances of an exceptionally rich form of homoeoteleuton; one remarkably close to rhyme proper. Phrases like jako ubiti i pogubiti xotjağče rhyme not only infinitive endings but also part of the root. 46 Nonetheless, this is not true rhyme, only the illusion of it created by rhyming verbal and nominal endings together with a certain degree of aural similarity in their roots (and prefixes where relevant). Frequently these rhyming words also contain an identical number of syllables, which auds to the impression of rhyme. Alost are pairs of words incorporated into a broader pattern of rhythm, such as the example arove or the phrase pourazanije i poruganije which appears in the shaman's admission of defeat. 47 further proportion are employed to render an antithesis more striking, as: не оо от иудрости, но от грубости...убвдихся, or:

бых ти досадитель, нынь похвалитель. (f. 763 . a weak example with only the two vowels o, a repeated)

The finest example is mach closer to true rhyme. Thus Stefan explains to the permians wily lie maj not inflict jhysical punishment and death on the defeated staman:

не повель ии иучити, но учити с кротостию, и увецевати с тихостию.

As usual in the Life, the 'positive' side of the antithesis in terms of Stefan's argument is reinforced by another clause, identically structured,

46. f. 678. The stress however, probably lay on different syllables which would weaken its effect and diminish its clain to le true rhyme.

47. $.711 \mathrm{v}$ 
containing both the alliteration of $\underline{u}$ (učiti and uvešcevati) and gramatical rhyme. Hence the internal rhywe of mčctitučciti is reserved strictly for accentuation of the contrast, and an otherwise staccato effect avoided by means of these other devices. Epifanij then continues with a parallel construction:

ни повель кванити, но нвкаавти с милостир. (1. 713 v.)

This may however, have been viewed by Epifanij as paronomasia, a far commoner form of internal rhyme in the Life. The final form of rhyme of this type occurs in syntactic parallelism, as:

кто ми плачь Јтолит, кто чи печаль јтышить? (1. 754 v.) This particular example demonstrates clearly the origin of Epifanij's apparently novel form of rhyme, born of the marriage between other rhythaic devices, here verbal rhyme and alliteration.

Though Epifanij's 'rhyme' may originate in traditional rhetoric it nevertheless represents a new development in Russian hagiography. The nearest equivalent in Russian vitae is Nestor's učaše visją i utěšja podviga radi, ${ }^{48}$ which may be termed rhyme only by a stretch of the imagination, and should more correctly be described as alliteration. In Domentian's vitae however, isolated instances may be found, mainly of rhyming pairs such as i poznal i pozval. 49 Not surprisingly, since parallelism plays a relatively minor role in his pletenije sloves, rhyme does not appear in symetrical antithesis or isocolon. Furthermore, out of six possible examples in the Life of Sava one, slave visylaje is strictly speaking, only a form of alliteration.

Rhyme of this type is slightly more common in Evtinij's vitae than in the Life of Sava, three exanples in less than half the number of words.

48. Life of Feodosij, p. 57.

49. Life of Sava, p. 146 . 
Like Domentian and Epifanij, Evtimij employs rhyming pairs, like slavlaěăe i xvalěše ${ }^{50}$ or adds rhyme to isocolon:

сице свои оукраси првстоль, и сице свое оупасе стадо.

(Life of Ilarion, P. 54)

But even this example is less striking than many of Epifanij's; the

final vowels differ and maximum rhythm is avoided by not placing the verb at the end of the clause as Epifanij would have done. This is typical of the difference between the two writers.

It is also interesting to note that Paxomij's Life of Kirill of Belozersk, though written in a restrained form of pletenije sloves does not contain any exarples of rhyme, ${ }^{51}$ whereas Kiprian's Life of Peter, which is cosposed in a relatively simple unemotional style, contains no 1 ess than four examples, of which lživom i lstivom is the best. 52 It would be unreasonable on such flimsy evidence to revive the theory of Epifanij's dependence on Kiprian. This type of rhyme is not a stylistic device in its own right, but results from the concentration of traditional rhyming and rhythmic devices in single words. In the Life of Peter, it should be seen as a stylistic artifice which appealed particularly to Kiprian, who chose it out of a number of rhythmic devices to lend his work a modicum of rhythm; in the Life of Stefan, on the other hand it springs directly from Epifanij's attempts to make his work as rhythmic as possible, which leads to more frequent and more striking examples of this form of 'rhyme' than in other vitae.

50. Life of loan of Rila, p. 15 .

51. The one possible example on page 23, jako da sego radi ne rabi budea is probably unintentional. At any rate its effect is very small without rhythaic word arrangement.

52. Life of Peter, p. 171. 
vi. Rhyth and rhyee in the vitae of Donentian and Butind

The distinguishing features of Epifanij's prose rhyth energe more clearly through comparison with Domentian's and Evtimij's vitae. The significant differences in their application of these traditional rhetorical devices are further pointers to their respective appronches to hagiography. For exanple, whereas Epifanij piles rhythric clause upon rhythmic clause, Evtimij deliberately alters the word order of adjoining clauses to escape this effect. This example from the life of Petka dewonstrates this clearlys

Vi что ии пјочеЕ вь дльготоу простирати слово,

и слова слишетелгмь ојсрьдіе заграхдати,

а не кь житіл обратити се пртподобние,

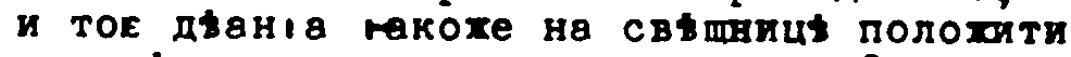

и вьсыхь слоуха истинор огласити?

The first, fourth and fifth cola conclude in rhyming infinitives, but in the first and third, the infinitive is 80 placed as to minimise the effect of rhyme. The passage nevertheless retains a discreet rhythm created not only by howoeoteleuton in three of the cola, but also by clauses of similar length and the alliteration of $\mathrm{s}$ in the first and second clauses. It exemplifies Evtimij's solem and elegant rhetorical style.

Not merely does Evtimij avoid lengthy rhythmic patterns but also hesitates to layer one rhythmic device on top of another as Epifanij does. When he does so, it is normally in prayers where rhythm is traditionally present, or in the lyrical mowents of his concluding eulogies. At their best, such as when Evtinij addresses Petka, these are admirable examples of rhetorical prose:

Тн застоупница соущинь вь бьдахз, обоуревагиниь пристанипе: твов рака благодытные точить строуе,

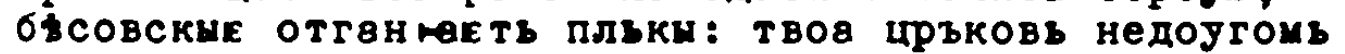
отгнаніе, сльпиин прозрьне, прокахениимь очипеніе. 
But when he, like Epifanij, atteapts to expand traditional panegyric formulae, the result is less effective than in the Life of Stefan: 53

вsсtх бо сих имаши искојсь, въсь таготнав подАль еск рөди Тоистовн црвкве, ересемь въствнія ојтолиль еси, сзпротивА МА сА блвгочвстів догивтом хытростіх доуховнох на благочвстіе обратиль еси, црзкви въздвигль еси Христоу, богоу намемоу, прьльшены обратиль еси, бвсноухпіих сА исцвлиль еси, ересень кззни разориль еси, добрыимь подвигомь подвизвл сА еси, теченіе скончаль еси и вьрх сзблюль еси...

$$
\text { (Life of Ilarion, p. } 58 . \text { ) }
$$

Even in this obviously emotional passage the clauses vary considerably in length and the word order is sometimes altered to avoid verbal rhyme. But as a rule, Evtimij's restrained rhetoric is highly successful; more than Epifanij, he peraits single rhythmic devices to stand out frov the surrounding sentences and hence gain waximu effect as here, in this series of anaphoric cola of sibilar but not identical length and construction:

$\because$ o cen' орсто бользновяше, како оукрасить свьтилникг, чоко "всло испльнить, како львамь сьликьствоугть ћоудрыимь, како хенихова насладить се зрьнів, куасоты, слевы, сввтлости, свпрвбыввнів, ила:енства.

\section{(Life of Petka, p. 64.)}

Evtimij's unobtrusive rhytho and Epifanij's blatantly poetic prose style both spring from their concepts of hagiography. 54

53. Cf. If. 752 r. and $766 \mathrm{ff}$.

54. Manson argues (op. cit. pp. 228-9), that Epifanij was not imitated because his style was excessive even for the taste of the $t i w e$, whereas Paxomij's vitae, stylistically wach closer to Evtinij's, served as codels for later hagiographers. It is ach ore likely that other writers lacked Epifanij's verbal skill and literary vision. Paxonij was imitated because his vitae were of manageable length and style, and hence were peculiarly suited to be models. Manson considers that the unusual structural features of Epifanij's vitae attracted disapproval, and in the case of the Life of Sergij, even revision, but it is nore probable that practical reasons dictated Paxomij's abbreviation of the work. After all, Epifanij's nicknane, the Most Wise, suggests that he was held in great respect. 
Both Epifanij and Domentian compose immensely long sentences, but where Epifanif's are rhetorical periods divisible into units of a manageable length with rhythmic devices lending them a dynamism, Dowentian's are diffuse and unwieldy. This is an important contributory factor in the annihilation of the terrestial associations of Sava's and Simeon's 1ives. In spite of the pleonastic style of Epifanij's and Evtimij's vitae, it is easy to follow the points they make, but in Domentian's vitae, the thread of the narrative is ever more difficult to grasp as clause follows upon clause. Thus s

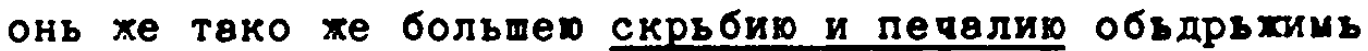
прытопльише сльзы проливваше, поминав светог юностьног прьбнвание вв Светыи Гору, и сльзотопвног

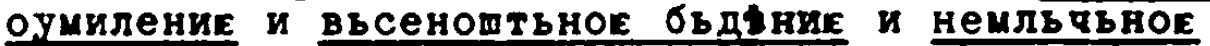

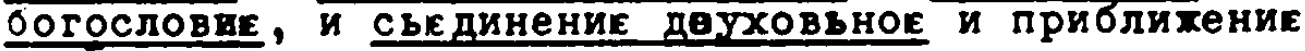
кь Еогоу честымия и Единодоушьныини и Еднно-

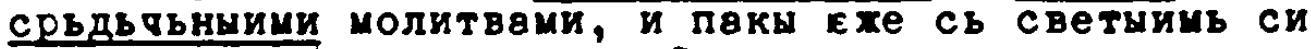
родителгив богоносьниимв Симеономв поминав свето-

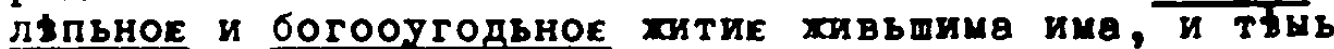
кь Богоу приблихивьшима се, и паки сьгншьнеЕ разлоучение, и напрьдь того не надыншта се достигноути, жалостию доухв растрьзае се, и давь мирь вьсумв светинмв брвтинвив...

(Life of Sara, p. 225)

The passage expresses Sava's sorrow at his impending departure from Athos. While a modern writer might depict this in a few simple but telling words, and Epifanij in parallel rhythmic clauses, Domentian makes little use of parallelism and verbal rhyme. On the other hand his prose is not unrhythmical, but it is normally pairs of words or short phrases, (as in the groups underlined in the above quotation), which bear the rhythm. Indeed, rhyming pairs like svetitelje i ucitelje ${ }^{55}$ and alliteration are more common than in the Life of Stefan, and they stand out because clauses are seldom subjected to overall patterning. Though rare, parallelism and verbal rhyme do occur in bomentian's

55. Life of Sava, p. 131. 
pletenije sloves, in prayers and traditional formulae as might be expected, 56 and less predictably in speeches delivered by Sava. 57 In the speeches, they are evidently meant to convey Sava's moral superiority and great powers of persuasion. Domentian also occasionally employs rhythm to bring a passage to a climax, as when he concludes his introduction to Sava's speech to the assembled bishops of Serbia in phrases with verbal rhymes: ... светие и. ботопропов двние сьборы често сьбирае, и сь тьии богоизбрандими свьтильнивн, Сь ЕпископЫ и сь прџподобвныими отьци, прьчитоую ввроЈ христовоУ понавлак, и вьсакомоу благозаконию

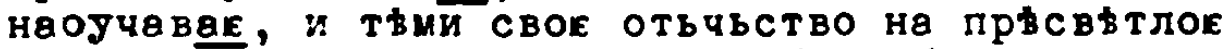
благочьстие извттае, самь собою образь имь првд-

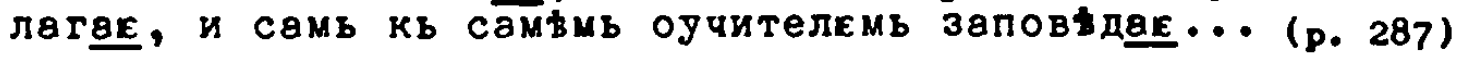

It should be noted that clauses vary much more in length than would be expected from Epifanij.

Anaphora appears no more than twenty times in the Life of Sava and and is thus much less common than in the Life of Stefan. Even the lyrical description of the joyful reception of Sava's soul in heaven merits only four parallel phrases beginning identically (with ideže), 58 and compares badly with Epifanij's characterisation of Permian idolatry in eleven similar clauses. 59 Uften, in both Vomentian's and Evtimij's Lives anaphora is the only rhythmic device linking the passage.

Clearly Domentian's treatment of rhythm is closer to Evtimij's than Lipifanij's, although his conception of hagiography as a whole is closer to Epifanij. The pletenije sloves of the two South Slavs cannot match the rhythmic intricacies of the Life of Stefan. Evtimij deliberately

56. In the prayers on pp. 127, 252 of the Life of Sava, and in the panegyrical topos on p. 253 for example.

57. Life of Sava, pp. 232, 240, 242, 253, 292, 293.

53. Life of Sava, p. 332 .

59. f. 670 . 
avoids the blatant rhythmic effects Epifanif so loves, because they do not accord with his traditionalist view of hagiography. In the light of Domentian's concept of his work, there would seew no reason why he should not employ rhythe as inteneively as Epifanij. But it was probably beyond his capabilities to enintain such a style in a vita of such length, and it was essential to his concept of hagiography that the whole of the work should be written in wore or less the same tone.

If the extent and originality of rhythmic devices in pletenije eloves are to be assessed, comparisons with the Slavonic hagiographic tradition are unavoidable. In the earliest Slavonic rhetorical Life, the Vita Constantini, significant differences are imediately detectable. These spring from the dynamic style, in which each clause, as a rule, contributes to the development of the argument or narration, and which thus presents a direct contrast to pletenije sloves, where whole sentences and clauses merely embroider previous statements. A static style is not peculiar to hagiography composed in pletenije sloves, for it stems largely from the influence of the psalms on Orthodox Slavonic literatures. From the enclosed unit of two interlocking cola, poetic prose developed units containing any number of elements. The author of the Vita Constantini, who had probably received a eecular Byzantine education, 60 neither initated the psalo verse nor its later developents. This fact, together with an overall emphasis on stylistic restraint, means that rhythmic rhetorical devices are extremely rare. Clauses are frequently similar in length but not construction. This makes for easy reading, as do the numerous pairs of words which contribute wore than any other device to the rhythm of the work. The only context in which greater use is made of rhythmic structuring is in the prayers in the vita, which depend upon 
different stylistic tradition.

The increased number of all forms of rhythmic device in Nestor's Life of Feodosij reflects the growing influence of psalms. Syntactic parallelism and verbal rhyme occur when Nestor wishes to convey a sense of drama, as in the description of the devils visiting Feodosij in his cel1:

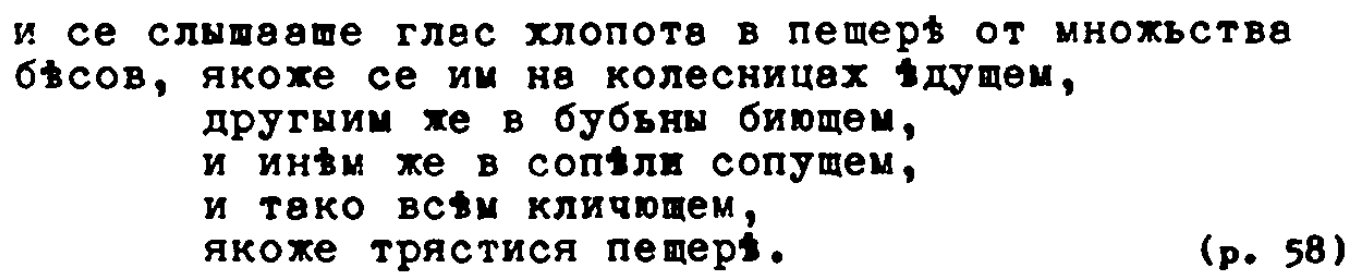

But on the whole, Nestor maintains a brisk narrative pace; other rhythmic passages are brief and well as traditional in format, as:

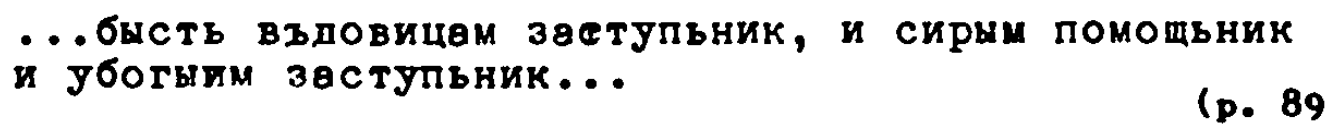
Though a later work, Kiprian's Life of Peter contains even less rhythm than the Life of Feodosij. Striking examples of any of the rhythmic devices are most uncommon and parallelism is extremely rare. It would seem, therefore, that the immediate source of rhythm in Epifanij's, Evtimij's and Domentian's prose is not the rletorical vita 61 clues are provided by the pervasive presence of rhythm in the prayers in all vitae. This suggests that devices traditionally found in prayers in Lives were transferred to the main body of the work. Various rhythmic devices occur in the prayers and responses of the Liturgy, where the sentence is broken up into cola of a length suitable for pronunciation aloud, but which are seldom identical or nearly identical in length. Anaphora is commonly found linking a series of clauses not otherwise rhythmically united, a

61. The ultimate sources are, as mentioned above, Hebrew poetry and Classical rhetoric, but the latter was presented through the medium of ecclesiastical prose genres, while the former came both directly and indirectly, but alone cannot explain the intricacies of pletenije sloves. 
process clearly observable in Drtiaij's and Domentian's Vitae. Anaphora is less often combined with other rhythnic devices as in the Life of Stefan, and when it is, wre than two units do not appear. Syntactic parallelise is also relatively uncowson, though less rare in responses. As with anaphora, instances of wore than two such clauses are for, though short phrases occur wore frequently:

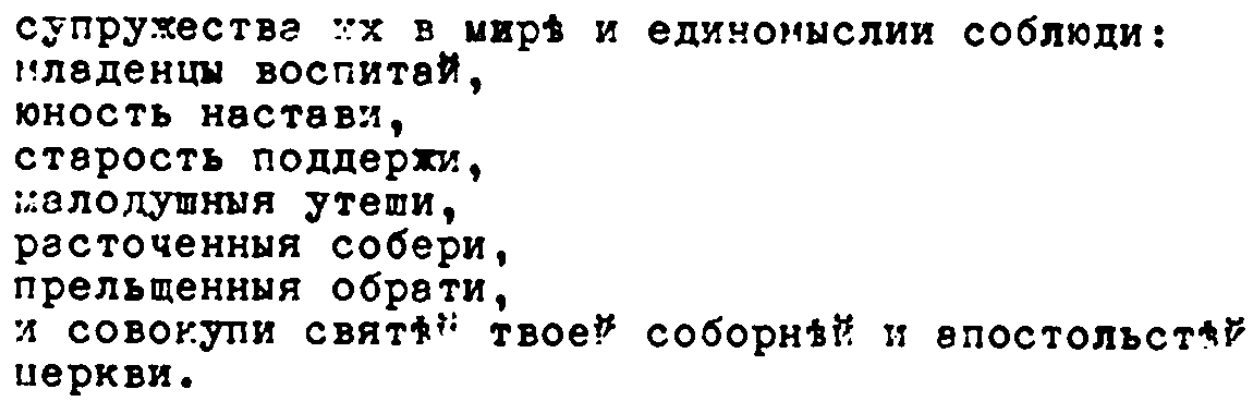

(Lituroy of Basil the Great, Kern, p. 294)

Verbal rhyee arises out of parallelism as in the example above, and is therefore also relatively uncomon. Nevertheless, though rhythaic devices are eoployed with some restraint, the style of the Liturgy remins a poetic one, which undoubtedly affected the genre of the encowium and the eulogies that conclude the rhetorical vita. The hagiographers writing in pletenije sloves simply transferred this poetic style to the main body of their works.

This explanation, though adequate for Evtimij's and Domentian's vitae, does not solve the problem of how Epifanij's use of these traditional rhythmic devices came to be so much more complex. One link in the chain of prose development leading to Epifanij, which can help to elucidate the origins of his rhythnic style is the collection of prayers composed by Kirill of Turov. These betray that dependence on the psalms that Lixacer saw as a hallwark of ecclesiastical prose style in tussia and other Orthodox Slar countries. Here the extension of the doublehinged psala verse into strings is readily observable, as is a significant increase in the use of anaphora, parallelisa and verbal rhyme, 
although the word order is still occasionally altered to avoid rhyme. 62 Above all, Kirill's style conveys his personal feelings just as Epifanij's does in the Life of Stefan. But similarities notwithstanding, Epifanij's style is infinitely more intricate. It is possible that he was directly influenced by Kirill of Turov, but it would be simplistic to attribute the dramatic increase in rhythm and rhyme to one source. After all, similar rhythmic devices are to be found in the sermons of Ilarion and Kirill as well as in the more obviously poetic hymns of the Orthodox Church. It would appear that the hagiographers of pletenije sloves raided the whole store of liturgical poetry for the means of lending greater rhythm to their works, but that Epifanij, alone of the three developed rhythm and rhyme to a greater extent than is found elsewhere, even in liturgical poetry.

In conclusion, it should perhaps be further emphasized that the rich rhythmic texture of the Life of Stefan of Perm' is dependent upon the interweaving of different rhythmic devices. This is a phenomenon embracing more than the structural rhrthmic devices examined in this chapter, for Epifanij may add to them alliteration or assonance, pairs or groups of three words or phrases in which the opening letters, the endings, the prefix, stress or one half of a compound word may be identical. The concentration of these into one passage is the clearest indication of Epifanij's stylistic talent and innovation.

62. For example Gebete, p. 303. 


\section{CONCLUSION}

When Epifanij Preaydryj wrote in the conclusion to the Life of Stefan of Pere' that love of Stefan drew hie na poxvalenije i na pletenije eloves, he neither invented the term pletenije sloves nor the style. One is rooted in the traditions of the Classical Greak encomius, the other in Byzantine ecclesiastical poetry and rhetorical prose, and ultimately in the twin sources of Old Testawent poetry and Classical rhetoric. All the formal tricks of style associated with pletenije sloves may be found in the ecclesiastical literature of an earlier period.

Nevertheless, the tere is a useful means of characterising the ornate style that was introduced into the vita by the Sarb Donentian in the thirteenth century. A similar but apparently independent style appears a century later in the vitae of Evtinij of Turnovo, and shortly afterwards in Kussian hagiography with Epifanij Prewudryj's Life of Stefan of Pera'. Epifanij himself seens to owe nothing to Evtimij, but it was Evtinij's brand of controlled word-weaving that was brought to Pussia by writers such as Paxomij Logofet and Grigorij Camblak and which became the model for sixteenth century fussian hagiography. It is at this later period that the term pletenije sloves acquires its negative connotations, for there was little to justify florid verbal patterning without the deep sense of involvenent that characterises the work of Epifanij and Domentian, or the astery of panegyric rhetoric found in Evtinij's vitae.

Though disparate in approach, Epifanij, Evtimij and Domentian possess sufficient in comon to permit them to be grouped together as writers. They share a desire to increase the personal element in their works, whether by direct statement in the exordium and conclusion or indirectly

1. . 775 . 
by infusing the work with their om personal ewotions. They are all wore interested in conveying states of emotion in the abjects of their vitae than had previously been the case in Slavonic hagiography. They share the transfer of a series of poetic devices from lituroical poetry into hagiography or fros the enconiun into the vita. Paronomsia, anaphora, homeoteleuton and balanced cola are all more frequent than had been the case in earlier Lives. The sentence becowes nore static; whole cola, short phrases and individual words are repeated in aimilar form hence the vast increase in the use of pairs of synonyas and long enumerative chains, themselves usually consisting of synonyms or near-synonym. The style is one of conscious artifice, wrked out awong other things by a great increase in the use of composita, traditionally a stylistic feature of prayers. These serve to widen the gap between the vernacular and the encomiastic rhetoric of pletenije sloves. And the creation of a style even wore remote from conversational speech is reflected also in the large numbers of biblical quotations which add authority to the author's atatements, or by virtue of their poetic nature appeal strongly to the emotions. At the sace tiw syabolic inagery reaches a high point of developent. But wch wore interesting than the general imilarities are the differences that underlie thee. For perhaps pletenije sloves should be divided into two basic types: wonastic and non-monastic. Monastic pletenije loves is the effusive embroidered style created by monks like Epifanij and Dosentian, resident in inportant spiritual centres. Unfettered by a secular training in rhetoric, steeped in the poetry of the Paalms and the liturgy, Epifanij and Domentian regarded the ornate style as specific to ecclesiastical literature. The most sacred form of expression was the language of religious poetry, which they borrowed for their long eotional vitae. Non-monastic Lives on the other hand, were 
composed by those who, though they had spent poriods in retreat in momsteries, were primrily wers of the Cmurch hierarchy. Such are Ertinij. Grigorij Camblak and Kiprian, who were all well-travelled, well educated and possessed a breadth of outlook lacking in the monastic writers. For them rhetoric could not be a specifically ecclesiastical manner of writing: they were aware that all kinds of secular literature and even documents and charters wight be composed in such a style. Their desire to convey to their audience their reverence for the subjects of their works was tempered by a sense of restraint and propriety, such that the stylistic innovations wich they introduced into their Lives are wch wore woderate. Though Evtimij's vitae are more emotive than wost earlier Lives, he allows biographical facts to speak for themselves uch wore than do Domentian and Epifanij. Just as Bulgarian manuscript illumination of the fourteenth century displays no recognisably national features but is a Byzantine provincial style, so too Evtimij's vitae conform to Byzantine standards.

Domentian's and Epifanij's greater provincialism caused them to compose vitae that are much more original in approach than contemporary Greek or Bulgarian Lives, simply because they were unaware of the denands other hagiographers laid upon themselves. Of course hagiographic conventions played a large role in their selection of aterial, its presentation and in phraseology, but the concept of regulating style according to criteria applicable to all forms of literature, both religious and secular, was alien to them. Their personal approaches to hagiography thus energed in a way that would not have been possible had they been products of a more sophisticated milieu.

Dowentian's approach is to eliminate as far as possible the terrestial associations of Sava's and Siweon's lives by strengthening still 
rurther the tendency of hagiography towards an esoteric language. Biographical information is obscured by strings of epithets and passages of eulogy. Sentences are so drawn out that the listener is constantly aware of the intiente connections with the language of prayers. To further the unworldly character of his work Domentian rejects the conventional atructural contrasts of the vita, producing instead works which are not divided into exordium, body and conclusion, and which are cosposed in aniforn tone of elevated praise. He also reduces to a winima the use of antithesis, whether traditional contrasts between subject and author or subject and those he encountered in his lifetime, or short antitheses that commonly form part of the accepted style for the genre. Only pairs such as 'earthly angel and heavenly wan' may be found with any frequency and these in fact assist Domentian's conception of Sava's and Simeon's lives as essentially heavenly events. Rhetorical devices such as enumeration which in Epifanij's pletenije sloves possess a dual function, in Domentian's vitae serve solely to abstract the exposition. It further follows from his decision to maintain the elevated style throughout, that passages of intense rhythw do not occur: anaphora and homeoeteleuton occur frequently but are rarely very highly developed or grouped together. Domentian prefers the discreet effects of alliteration to the blatant rhythms of the life of stefan.

For Epifanij's work offers a different but equally original approach to the vita. Far from rejecting conventional contrasts, structural, thematic and stylistic, Epifanij heightens them to the point where contrast becomes the organising principle of the work. He begins from a position of veneration for Stefan, placing him upon a pedestal of virtue, and then proceeds to a series of contrasts between himself, other men and this paragon, in which he represents the depths of sinfulness and unworthiness. He is clearly determined that others shall share his sincere admiration 
for Stefan, and this prompt his constant search for greater expressiveness. Contrast is likewise the key to the presentation of the ascesis as aeries of vivid dranatic scenes alternating with passages of abstract eulogy or mditation, while the body of the work, the account of the aission to the Peraians itself offers a structural contrast to the inspirational lyricisa of the three concluding laments. Even the personal element characteristic of Lives witten in pletenije soves takes a form consistent with Epifanij's general approach: either through the unique development of the humility topos or the presentation of states of ewotion (Stefan's, the Permians' and Epifanij's own), which increase the impact of the work as a whole.

The work is further unified by a series of thematic contrasts, broad antitheses such as the symbolic contrast between darkness and light, which constantly recur in the Life. As a rule, this method of contrast, which rests essentially upon the juxtaposition of verisimilitude and reallife detail does not conflict with the timeless aims of the vita. Indeed for the wost part Epifanij succeeds brilliantly because the real-1ife detail usually avoids overt polemic and contemporary references other than dates. Occasionally he rails, and this is always when he turns to polenic. His desire to convince sometimes leads hil into arguments with contenporary detractors of Stefan's achievenents, thereby destroying the elevated tone of lyrical adairation which pervades the work. Or course it night be aroued that the portrait of Stefan is itself a polencal one, since it holds up for emlation a human sybol of specific virtues (long-suffering, faith, love and non anterialism), but though these same virtues were later ideal ised by the Non-possessors, and at this period presunably represented a trend in Russian conasticisa, this element is not ade overtly polemical, and thus does not offend hagiographic canons. 
For every aspect of the life of Stefan is tailored to fit in with Epifanij's strong sense of moral hierarchy. Both dramtic scenes and eulogy are conveyed in a style as expressive as Epifanij could nake it. Though certain devices are wre comon in passages of panegyric, no device is restricted entirely to one section. Thus each has a dual function, in some places serving to abstract or add evotional colouring, and in others to emphasize or render a passage more concrete. If the modern reader sometimes feels that Epifanij is carried away by his word-weaving to a degree unacceptable to contemporary tastes, and that he stops only when the spring of his inventiveness dries up, he should not forget that Epifanij's pletenije sloves springs not from a mere formalistic love of words, but frow a profound sense of his own inadequacy as man and writer and a love of Stefan that prompts a search for greater expressiveness. As result, Epifanij's life of Stefan is probably the nost original Russian vita ever written, though the term 'original' wast naturally be understood in the context of mediaeval literary etiquette and the system of genres. Epifanij's man stylistic innovation was to transfer from liturgical poetry and panegyric literature, devices which had previously played only a small role in the vita and then predominantly in the conclusion. Unlike either Evtimij or Domentian, Epifanij so orders the rhythmic and acoustic devices of prayers, hymns and responses that he often actually produces a more rhythaical prose than in the original. The same sure stylistic touch is evident in the subtly new treatment of traditional images, in the invention of expressive compound neologisns and varied and unusual treatment of biblical quotations. The text of the life of Stefan of Pera' is a long religious prose poem. It is not surprising that in spite of the respect Epifanij was accorded by contemporaries he was so little initated. Few possessed such a linguistic talent or were spurred 
on by a concept of hagiography that necessitated extending stylistic boundaries. Above all the excessive length of the life of Stefan as of Domentian's Life of Sara, a direct result of their respective approaches, finally proved iapractical. Though the life of Stefen was not rewritten, Epifanif's other vita, the Life of the popular Sergij of Radonez ras revised and abridged by Paxamij to make it more suitable for use in church and monatery. Domentian's vitae were also rewritten, in this case by two different people each presumably dissatisfied with the unworldly tone and burdensome length of his work. Thus monstic pletenije sloves for all its brilliance and originality proved relatively unsuccessful in the context of the functional demands of hagiography. Though it was advired and succeeded in its ibpact on the audience, functional demands weant that the wore controlled non-monastic pletenije sloves was to be the dominant influence on the developent of hagiography in Passia. 


\section{Epifanij Premudryj's Life of Stefan of Pera'}

The edition employed was:

- v. Družinin, Žitije av. Stefana episkopa pereskogo,

(Arxeografǐ̌eskaja komissija), St. P., 1897, reprinted

with an introduction by D. Čižerskij, (Apophoreta Slavica,

II), The Hague, 1959.

Reference was also made to:

- G. A. Kušelev-Bezborodko, Pamjatniki starinnoj russkoj

literatury, II, St. P., 1862.

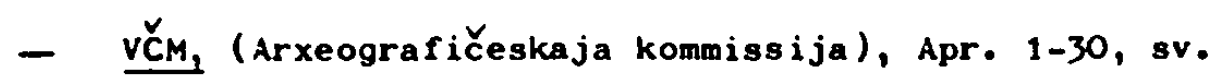

Apr. 26, cols. 988-1109, M., 1910-6.

11. South Slavonic vitae composed in pletenije sloves, used in detailed comparisons with the Life of Stefan:

i. Evtimij of Turnovo:

- Life of riloteja, pp. 78-99

- Life of loan of Kila, pp. 5-26

- Life of Ilarion of Măglen, pp. 27-58

- Life of Petka, pp. 59-77,

in E. Kaluiniacki, werke des Patriarchen von Bulgarien

Euthymius (1375-93), Vienna, 1901, reprinted with an introduction by I. Dujčev, London, 1971. 
ii. Domentian:

- Life of Sava, p. 118-345.

- Life of siecon, pp. 1-117, in Dj. Danicić, Zivot sv. Simuma i sv. Save, Bolgrade, 1865.

\section{Other vorks cuployed for purposes of comparison}

i. Hagiographical rorks:

Anonymous:

- Life of Athanasia, in V̌́M, (Arxeografičeskaja kommissija), Apr. 1-30, sv. Apr. 11, M., 1910-6, cols. $373-90$

- Life of Athanasius, bisbop of Alexandria, in $0 . A$. Knjazevskaja, V. C. Den'janov, M. V. Ljapon, S. I. Kotkor, Uspenskij sbomik XII-XIII vv., M., 1971, pp. 38-42

- Passion and Encomius to Boris and Gleb, in D. I. Abramovič, Zitija svjatyx mčenikor Borisa i Globa i služby in,

(Panjatniki drevnerusskoj literatury, II), Petrograd, 1916, reprinted with an introduction by L. Mlller, Die altrussischen hagiographischen przthlungen und liturgischen Dichtungen uber die Heiligen Boris und Gleb, (Slavische Propyläen, XIV), Munich, 1967, pp. 27-66.

- Vita Constantini, in P. A. Lavrov, Materialy po istorii dromejšej slavjenakoj pis'mennosti, (Trudy slavjanskoj komissii, I) L., 1936, pp. 1-36, reprinted (Slavistic Printings and Reprintings, LXVII), The thase, 1966, pp. $1-67$. 
- Life of Methodius in A. A. Samator and P. A. Lavrov, Sbornik XII veka coskovskogo uspenskogo sobora, pt. i, ČIDR, II, M. , 1899, reprinted with an introduction by

D. XiZerskij, (Apophoreta Slavica, I), The Hague, 1957, pp. 148-58; or in 0. A. Knjazerskaja, V. G. Dem'janov, M. V. Ljapon, S. I. Kotkov, Uspenskij sbornik XII-XIII vv., M. , 1971, pp. $188-98$.

- Martyrdom of St. Vitus, in 0. A. Knjazevskaja, V. G. Dem'janov, M. V. Ljapon, S. I. Kotkov, Uspenskij sbornik XII-XIII vv., M., 1971, pp. 220-9.

Athanasius: Life of Antony, in B. St. Angelov, Iz starata bălgarska, ruska i srăbska literatura, II, jofia, 1967, pp. $109-30$.

Callistos: Life of Teodosij of Turnovo, in V. N. Llatarski, 'Litije i žizn' prepodobnago otca našego Teodosija', Sbornik za narodni umotvorenija, nauka i kni žnina, $x x$, no. 5, Sofia, 1904 .

Grigorij Camblak: Encomium to Evtimij of Turnovo, in E. KaXuiniacki, Aus der panegyrischen Literatur der SUdslaven, Vienna, 1901, reprinted with an introduction by I. Dujčerev, London, 1971, pp. 15-88.

Grigorij Camblak, Encomium to Kiprian, in B. St. Angelov, Iz starata bălgarska, ruska, i srăbska 1iteratura, I, Sofia, 1958, pp. 180-90. 
Efrem, Life of Avraapij of Smolensk, in S. P. Rozanov, Žitija prepodobnogo Avraanija Smolenskono i slu姑y em, (Panjatniki drevneruekoj literatury, I), St. P., 1912, reprinted with an introduction by D. TschiZewskij, Die altrussischen hagiographischen Erzlhlungen und liturgischen Dichtungen Uber den heiligen Avraamij Smolenakij, (Slavische Propylaten, XV), Munich, 1970

Epifanij Premudryj/Paxomij Logofet, Life of Sergij of Radonež, in Arximandrit Leonid, Žitije prepodobnogo i bogonosnogo otca nǎ̌ego Sergija Čudotvorca i poxval'noje emu slovo napisannyje učenikom eqo Epi fanijem Premudry $v$ XV v. . (PDP, LXVIII), St. P., 1885; also in VČM, (Arxeografičeskaja Kormissija), Sept. 25-30, St. P., 1883, cols. 1408-1563; also in N. S. Tixonravov, Drevnije žitija prepodobnogo Sergija Radonełskogo, pts. I, II, reprinted with an introduction by L. MUller, Die Legenden des Heiligen Sergij von Radonež, (Slavische Propylden, XVII), Munich, 1967.

Epifanij Premudryj, Encomium to Sergij of Radonež, in vČM, (Arxeografičeskaja komaissija), Sept. 25-30, St. P.. 1883, cols. 1563-79.

Evtimij of Turnovo, Enconiue to Constant ine and Helena, pp. 103-46, . Enconium to loan of Polybotue, pp. 181-202, Bncomium to Mixail of Potuka, pp. 170-80, Encomium to Nede la, pp. 147-69 of E. KaXuziniacki, Werke des Patriarchen von Bulgarien, Duthymius (1375-93), Vienna, 1901, reprinted with an introduction by I. Dujčev, London, 1971. 
Grigorij the Monk, Life of Romil in P. A. Syrku, Monaxa Grigorija 站ije prepodobnogo Romila (PDP, CXXXVI), St. P., 1900.

Kiprian, Life of Metropolitan Peter, in B. St. Angelov, Iz starata bălgarska, ruska i srăbska literatura, I, Sofia, 1958, pp. 159-76.

Nestor, Life of Feodosij of the Caves Monastery, in A. A. Saxmatov and P. A. Lavrov, Sbornik XII veka moskovskogo uspenskogo sobora, pt. i, COIDR, II, M., 1899, reprinted with an introduction by D. Čǐ̌evskij (Apophoreta Slavica, I), the Hague, 1957, pp. 40-96; or in 0. A. Knjazerskaja, V. G. Dem'janov, M. V. Ljapon, S. I. Kotkov, Uspenskij sbornik XII-XIII vv., M., 1971, pp. 71-135.

Nestor, Lection on Boris and Gleb, in U. I. Abramovič, Žzitija svjatyx muð̌enikov Borisa i Gleba i služby im, (Pamjatniki drevne-russkoj literatury, II), Petrograd, 1916, pp. 1-26, reprinted with an introduction by L. Mdler, Die altrussischen hagiographischen Erzahlungen und liturgischen Dichtungen tber die Heiligen Boris und Gleb, (Slavische Propyluen, XIV), Munich, 1967.

l'axomij Logofet, Life of Kirill of Belozergk, in V. Jablonskij, Paxomij Serb i ego agiografičceskije pisanija, St. P., 1908, appendix reprinted with an introduction by D. TschiŽewskij, Pachomij Logofet. Werke in Muswahl, (Slavische Propyluen, I), Munich, 1963, pp. 1-LXIII.

l'axomij Logofet, Life of Moisej of Novgorod, in V. Jablonskij, Paxomij Serb i ego agiografiČskije pisanija, St. P., 1908 , appendix reprinted with an introduction by D. Tschižewskij, Pachomij Logofet. Werke in Auswahl, (Slavische Mropylden, I), Aunich, 1963, pp. LXAXI-XCI. 
Paxowij Logofet, Life of Nikon of Radonez, in $V$. Jablonakij, Paxomij Serb i eqo agiografiCeskije pisanija, St. P., 1908, appendix reprinted with an introduction by D. Tschižewakij, Pachovij Logofet, Werke in Aurwahl, (Slavische Propyluen, I), Munich, 1963, pp. LXIV-LXXXI.

Paxomij Logofet, Life of Seroij of Radonež, see sv. Epifanij Premudryj/Paxowij Logofet, Life of Sergij of Radonež, supra.

Proxor ( 2), Life of Metropolitan Peter, (1st redaction), in Makarij, Istarija russkoj cerkvi, IV, pt. i, St. P., 1886, pp. $312-6$.

Simon and Polykarp, Patericon of the Kievan Monastery of the Caves,

in D. I. Abramovič, Kievo-Pečerskij paterik, Kiev, 1929, reprinted with an introduction by D. Tachižewakij, Das Paterikon des Kiever Hohlenklosters, (Slavische Propyllen, II), Munich, 1964.

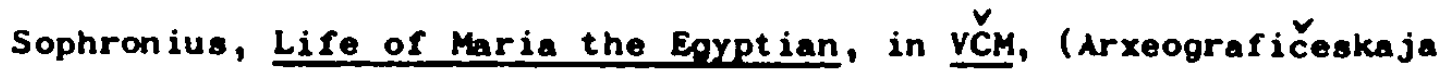
Komissija), Apr. 1-30, sv Apr. 1, M., 1916, cols. 5-33.

Teodosije, Life of Sava in Uj Uaničić, Život sv. Save, Belgrade, 1860.

ii. Non -hagiographical works:

Georgios Choiroboscos, Treatise on rhetoric in B. St. Angelov, Iz starata ruska, bălgaraka i srłaska literatura, II, Sofia, 1967, pp. 89-105.

Epifanij Premudryj, Letter to Kirill of Trer edited by O. A. Belobrova, in L. A. Dmitrijev and D. S. Lixačev (eds.), Izbornik. Sbornik proizvedenij literatury drevnej Rusi, M., 1969, pp. 398-403. 
Ilarion, Sermon on Law and Grace, in L. Muller, Des Metropoliten Ilarion Lobrede auf Vladiair den Heiligen und Glaubensbekenntnis, (Slavistische Studienbucher, II), Wiesbaden, 1965; also in N. N. Rozov, 'Sinodal'nyj episok sotinenij llariona - russkogo pisatelja XIV.', Slavia, XXXII, Prague, 1963, pp. 141-75.

Joseph the Philosopher, Rhetoric in extracts in modern Russian translation by T. A. Miller in L. A. Frejberg (ed.), Pagjatniki vizantijskoj literatury IX-XIV vekov, M., 1969, pp. $344-8$.

\section{Kirill of Turov, Parables, \\ - Pritča o celověstěj, dư̆i i o telesi, \\ - Povest. o bělorizcě čelověcě. \\ - Skazanije o černoriz'č'stěn' Činu, \\ in I. P. ùreain, 'Literaturnoje nasledije Kirilla Turovakogo', TODL, XII, M-L., 1956, pp. 340-61; the first two are also \\ available in K. F. Kalajdovič, Pamjatniki rossijskoj slovesnosti XII veka, $M_{.}, 1821$, pp. 117-31, 132-52, reprinted with an intro- duction by $v$. IschiZewskij, Kirill von Turov. Drel Erzahlungen, (Slavische Propylten, v), Munich, 1964.}

Kirill of Turov, Prayers, in 'Molitvy na vsju sedmicu sv. Kirilla, episkopa Turovskogo', Pravoslavnyj sobesednik, Kazan', 1857, pp. 235-60, 273-351, reprinted as Kirill von Turov. Gebete, (Slavische Propyluen, VI), Munich, 1965.

\footnotetext{
Kirill of nurov, Sermons;

- Sermon for Holy Week,

- Serwon for Easter Sunday,
} 
- Serwon for the Sunday after Eacter,

- Sermon for the 3rd Sunday after Easter.

in I. P. Eremin, 'Literaturnoje nasledije Kirilla Turovakogo', TODL, XIII, M-L., 1957, pp. 409-26.

Konstant in Kostenelki, Troatise in V. Jagić, Rasuǔ̌denija južnoslavjanskoj i russkoj stariny o cerkovno-slavjankson jazyke,

St. P., 1896, pp. 200-30; or in B. St. Angelov, Iz starata

bălgarska, ruska i grăbska literatura, II, Sof ia, 1967, pp. 200-30.

Constantine Manasses, Chronicle in I. Bogdan, Cronica lui Constantin Manasses. Traducere mediobulgară răcuţ pe la 1350, Bucharest, 1922, reprinted with an introduction by J. Schropfer, Die slavische Manasses-Chronik, (Slavische Propylden, XII), Mun ich, 1966. 
This bibliography makes no clains to be an exhaustive inventory of every work which went directly or indirectly into the writing of the thesis. It excludes firstly, those works which have so little bearing on the subject as to be of no assistance to anyone wishing to read more widely in and around the subject, and secondly those that refer specifically to one aspect of the thesis and wich are fully documented in the footnotes to the chapter concerned (for example to those on compound words and versification). Two articles likely to make a significant contribution to the study of Epifanij Premudryj's style but which have not yet appeared in print, are also included.

Adrianova-Peretc V. P., Očerki poet ičeskogo stilja drevnej Rusi, M-L, 1947.

- Slovo o Kitii i o prestavlenii velikogo knjazja Duitrija IvanoviČa, carja Rus'skago', TODL, V, M-L, 1947, pp. 73-96.

Aigrain R., L'Hagiographie, ses sources, ses béthodes, son histoire, Paris, 1953.

Antonova M. F., 'Slovo o Žitii i o prestavlenii velikogo knjazja Daitrija IvanoviČa, carja Russ'skago. (Voprosy atribucil i žanra)', rODL, XXVIII, L., 1974, pp. 140-54.

Appel 0., Die Vita des hl. Sargij von Radonež. Untersuchungen zur Textgeschichte, Munich, 1972.

Arbusow L., Colores rhetoriki, GUttingen, 1948. 
Arxangel'skij A. S., Tvorenije otcor cerkvi r dreverueskoj pie'eennosti, St. P., 1888.

Auty R., 'The Gospel and Psalter of Cherson: Syriac or Russian?' To honor Roman Jakobson, The Hegue, 1967, pp. 114-7.

Baldwin C. S., Mediaeval rhetoric and poetic, N.Y., 1928.

Barsukov N. P., Istolniki russkoj aqiografii, (PDP, LXXI), St. P., 1882.

Beck H.G., Kirche und theologische Literatur im byzantinischen Reich, Munich, 1959.

Begunov Ju. K., 'Probleay i aučenija toržestvennogo krasnorečija jű̌nyx i vostočnyx slavjan IX-XVI vv.', Slavjanskije literatury. VII MeŽdunarodny s'jezd slavistov, Varšava, avgust 1973 g., M., 1973, pp. $380-399$.

Belokurov S. A., Prepodobnyj Sergij Radonežskij i Troice-Sergieva lavra v russkoj literature, M., 1892.

Bimbaur H., 'Byzantine tradition transformed: the Old Serbian Vita', Aspects of the Balkans. Continuity and change. Contributions to the International Balkan Conference held at UCLA, October $23-8$, 1969, eds. H. Birnbaum and S. Vryonis Jnr., The Hague, 1972, pp. 243-84.

- 'Sone aspects of the Slavonic Renaissance', Slavonic and East European Review, XVLII, London, 1969, pp. 37-56. 
Borisevič L. S., Panjatniki coskovakoj literatury XIV-ną. XV rv., Avtoreferat na soiskanije ǔ̌enoj stepeni kandidata filolooičeskix nauk, M., 1951.

Bdrtnes J., 'Frame technique in Nestor's Life of Theodosius', ScandoSlavica, XIII, Copenhagen, 1967, pp. 5-16.

Bugoslavakij S. A., 'Literaturnaja tradicija v severnovostočnoj russkoj agiografii', Stat'i po slavjanskoj filologi i russkoj slovesnosti. (Sbornik statej $v$ čest' akadeaika Alekseja Ivanoviča Sobolevakogo), L., 1928 , pp. $332-6$.

Buxarev I., Žitija vsex svjatyx prazdnujeayx '.0ssijskoju Corkov'ju, M., 1896.

Buschieck C., Zur Wortbildung des Substantivsund Adjektivs in Altrussischen (an Hand des Wortmaterials zweier Viten Epifanij Premudry,js), Mannhein, 1969.

Č Ževikij D., Vergleichende Geschichte der Slavischen Literaturen, I-II, Berlin, 1968, trans. R. N. Porter and M. P. Rice, edited with a foreword by S. Zenkovaky (Comparative history of Slavic literatures), Nashville (Tenn.), 1971.

- History of Pussian literature. From the eleventh century to the end of the Barogue, The Hague, 1960.

- Introduction to Žitije av. Stefana episkopa peraskogo, reprinted from the edition of V. Družinin, (Apophoreta Slavica, II), The Hague, 1959, pp. I-XVIII. 


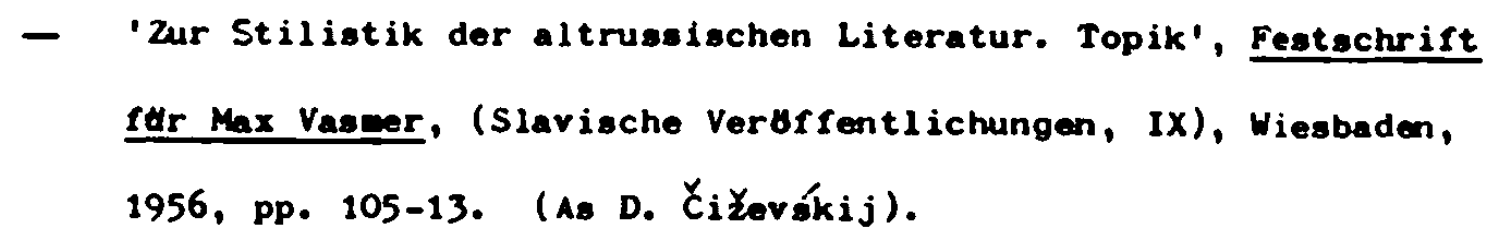

Curtius E. R., Duroplische Literatur und das lateinisches Mittelalter, Berne, 1948, trans. W. R. Trask, Duropean literature in the Lat in Middle Apes, London, 1953.

Dane M. M., 'Epiphanius' image of St. Stefan', Canadian Slavonic Papers, v, Toronto, 1961, pp. $72-86$

Davids A. J. M., 'Nil Sorakij und der Hesychasmas in Pussland', Jahrbuch der Usterreichischen byzant inischen Gesellschaft, XVIII, Vienna, 1969, pp. $167-94$.

Delehaye A., Cing lefons sur la éthode hagiographigue, (Subsidia hagiographica, XXI), Brussels, 1934.

- Les Passions des nartyres et les genres littéraires, Brussels, 1934.

Demina N., Troica Andreja Rubleva, M., 1963.

Dinekor P. S., Stara bhloaraka literatura, I-II, Soria, 1950.

Daitrijer L. A., 'Nerešennyje voprosy o proisxoždenii i istorii ekspressivno-emocional'nogo stilja XV v.', TODL, XX, M-L, 1964, pp. 72-89. 
- 'Rol' i mačenije aitropolita Kipriana $v$ istoril drevne-rusakoj literatury (k russko-bolgarskin literaturnym svjazjan XIV-XV vv.', TODL, XIX, M-L, 1963, PP. 215-54.

- Zitijnyje povesti russkogo severa kak pagjatniki literatury XIII-XVII VV., L., 1973.

Dujěer I., 'Centry vizantijsko-slavjanskogo obł̌enenija i sotrudniXestra', TODL, XIX, M-L, 1963, Pp. $107-29$.

von Eichen H., Geschichte und Syatem der Dittelalterlichen Weltanschauung, Stuttgart, 1887

Eissfeldt $0 .$, Einleitung in das Alte Testament, unter Einschluss der Apokryphen und Psoudepioraphen, THbingen, 1934, trans. P. R. Ackroyd, The Old Testament. An Introduction, Oxford, 1965.

Eremin I. P., 'Novejŭije issledovanija zudožestrennoj foray drernerusskix literaturnyx proizvedenij', TODL, XII, M-L, 1956, pp. 284-91.

Fedotor G. P., The Pussian religious aind, I-II, Canbridge (Mass.), 1966. - Svjatyje drevnej Pusi X-XVII st. , Paris, 1931.

Fennell J. and Stokes A., Early Russien literature, London, 1974.

Filaret (Gumilevskij D. G.), Obzor rusakoj duxornoj literatury, Xar'kor, 1859-61. 
Golubinskij E. E., Istorife kneoni zacil orjatyx V rusgkoj cerkvi, M. , 1903.

- latorija ruaskoj cerkri, vols. I-III, M., 1901-10, reprinted (Slavistic Printings and Reprintinge, CXVII), The thgue, 1969.

- Prepodobnyj Sergij Radonežkij i sozdannaja in Troickaja Lavra, M. , 1892.

Grixin V. A., 'Principy voplošcenija nravstrennogo ideala $v$ socinenijax Epifanija Premudrogo', Vestnik moskovskogo universiteta, (Serija filologija), 4, 1973, pp. 15-25.

- Probleur stilje drevnerusskoj eqiografii XIV-XV vV., M., 1974, pp. 1-64.

- 'Sjužet $i$ artorskije principy povestrovanija $v$ agiografičceskix proizvedenijax Epifanija Premudrogo', Filologičeskij sbornik, (Kazaxskij gosurdaratrennyj institut io S. M. Kirova), XII, Alma-Ata, 1973, pp. 79-86.

- Tvorčestro Epifanija Premudrogo i ogo mesto $v$ drennerusskoj kul'ture konca XIV-natala XV vv., (Avtoreferat dissertacii na soiskanije ućenoj stepeni kandidata filologičeskix nauk), M., 1974.

- Lanrovoje svojeobrazije agiografičeskix proizredenij Epifanija Premudrogo', Ǔ̌enyje zapiski pereskogo gosurdarstvennogo universiteta, (Serija filologija), Perw', 1975, in preparation. 
Gudzij N. K., Istorija drevnerugekoj Iiteratury, H., 1956.
Holthusen J., 'Bpifanij Precudryj und Gregor von Nysea', Festechrift IUr Mrgarete Woltner, ae 20 Goburtstag, Heidelberg, 1967, pp. $64-82$.

Ivanor J., Bălgarskoto knił̌onno rlijanije na Rusija pri vitropolit Kiprian (1375-1406)', Izvestija na Instituta za bäloaraka literatura, VI, Soria, 1958, Pp. $29-67$.

Jablonskij V., Paxomij Serb i ego agionrafiCegkije pisanija, St. P., 1908.

Jacimirakij A. I., Grigorij Cablak, St. P., 1904.

Jaxontov I., Žitija avjatyx severnorusakix podvi Znikor ponorgkogo kraja kak istori Ceakij istołnik, Kazan', 1882.

Kadlubovakij A., Očerki po istorii drevne-russkoj literatury žltijavjatyx, Warsaw, 1902.

Kiselkov V. S., Grigorij Sinait, predstavitel na nisticiza o Vizantija prez XIV v., Sofia, 1928.

- Mitropolit Grigorij Camblak, Sofia, 1946.

- Sr. Teodosij Tărnorgki, Sor ia, 1926.

Klibanov A. I., Reforacionnoje dviženije $v$ Rossi $v$ XIV-pervoj poloriny XYI VV., M., 1960 
K1jučevakij V. O., Žitija ovfatrx kak istoričeakij istoǔnik, M., 1871.

Kolloff E., Die sagenhafte und sybolische Thiergeschichte des Mittelaltera,

(Historisches Taschenbuch, IV, 8), Leipzig, 1867.

Kologrivov I., QXerki po istorii russkoj svjatosti, Brusse1s, 1961.

Konovalova O. F., 'Izobrazitel'nyje i emocional 'nyje funkcil epiteta $v$ Žitii Stefana Permokogo', TODL, XXVIII, L., 1974, pp. 325-34.

- 'K voprosu o literaturnoj pozicii pisatelja konca XIV V.', TODL, XIV, M-L., 1958, pp. 205-11.

- 'Pletenije sloves i pletenyj ornament konca XIV v.', TODL, XXII, M-L, 1966, pp. 101-12.

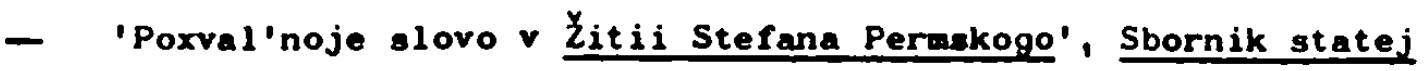
po metodlke prepodavani,ja inostrannyx jazykov i filologi

(Leningradskij texnologičeskij institut xolodil'noj pronyšlennosti), 2, L., 1965, pp. 98-112.

- 'Princip otbora faktičeskix svedenij $v$ Žitii Stefana Pereakogo', TODL, XXIV, M-L., 1969, pp. 136-9.

- 'Sravnenije kak literaturnyj prijem $v$ Žitii Stefana Peragkogo, napisannom Epifanijem Premudrya', Sbornik statej po metodike prepodavanija inostrannyx jazykov i filologii, (Leningradskij texnologičeskij institut xolodil'noj proryšlennosti), I, L., 1963, pp. 117-38.

Kraft C. F., The strophic structure of Hebrew poetry, Chicago, 1938. 
Krašennikov A., 'Apostol'skij podvig sv. Stefana Permakogo', Zürnal mokovskoj Patriarxii, 4, M., 1949, pp. 15-22.

Krumbacher C., Geschichte der byzantinischen Literatur von Just inien bis zul Ende des oströnischen Reiches, Munich, 1883.

Kučkin V. A., 'Skazanije o smerti mitropolita Petra', TODL, XVIII, M., 1962, pp. 59-80.

Kujew K. M., Konstantin Kosteneski $*$ literature buYgarskiej $i$ serbskiej, Krakow, 1950.

Leonid (Arximandrit), Iz istorii jugo-slavjanskogo Eonašestva XIV stoletije, M., 1871.

Levčenko M. V., očerki po istorii russko-vizantijakix otnošeni, , M., 1956.

von Lilienfeld F., 'Der athonitische Hesychasmus des 14. und 15. Jahrhunderts it Lichte der zeitgenbssischen russischen quellen', Jahrbücher fur Geschichte Osteuropas, VI, Munich, 1958, pp. 436-48.

Lixą̌ev D. S., 'Izobraženije ljudej $v$ žitijnoj literature XIV-XV vV', TODL, XII, M-L., 1956, pp. 105-15.

- Kul'tura Rusi vremeni Andreja Publeva i Epifanija Premudrogo, M-L, 1962 .

- 'Nekotoryje zadači izučenija vtorogo južnoslavjanskogo vlijanija

v Rossii', Issledovanija po slavjanskomu literaturovedeniju i fol'kloristike, M., 1960, pp. 95-152. 
- Poetike dremeruekoj literatury, L., 1967.

- 'Srednevekovyj siurolizm $v$ stilističeskix sistemx dromej

Rusi i puti ego preodolenija', Nkadeniku Viktoru Vladieirovǐ̌u Vinogradoru k eqo Yeatidesjati-letiju. Sbornik atatej, M., 1956. pp. $165-71$

- Tekstologije. M-L., 1963.

- Takstolooija, kratkij očerk, M-L., 1964.

Loparev $X_{r}$, , 'Opisanije nekotoryx greXeskix Žitij svjatyx', Vizantijakij vremennik, IV, St. P., 1897, Pp. 337-401.

- 'Vizantijekije Žitija evjatyx VIII-IX vv•', Vizantijekij vremennik, XVII, St. P., 1910, Pp. 1-224; XVIII, St. P., 1911, pp. 1-224; XIX, St. P., 1912, pp. 1-151.

Lur'e Ja. S. (ed.), Istoki russkoj belletristiki, L., 1970.

Makarij, Istorija rusakoj cerkvi, vols. I-XII, St. P., 1857-83.

Mile E., L'Art religieux de XIII siècle en France, Paris, 1908; trans. D. Nussey, The Gothic Inage, London, 1913.

Manson J. P., Studies in Pussian hagiography during the period of the second South Slavic influence, (Ph. D. thesis for Harrard University), Carbridge, (Mass.), 1968.

Mansvetor I., Mitropolit Kiprian $v$ eqo lituroičeskoj dejatel'nosti. M., 1882 . 
meter K., Grigorij Carblak, Soria, 1970.

Moyendorff J., Introduction a l'ótude de Grópoire Palaeas, Paria, 1959; trans. G. Lawrence, A study of Gregory Palems, London, 1964. - St. Grénoire Palanas et la gustique orthodoxe, Paris, 1959.

Mošin V., 'O periodizacii russko-južnoslavjanskix literaturnyx svjazej', TODL, XIX, M-L., 1963, pp. 28-107.

Mulić M., 'Pletenije sloves i hesihazam', RZSF, VII, Zagreb, 1965, pp. $141-56$.

- 'Serbskije agiografy XIII-XIV vv. i osobennosti ix stilja', TODL, XXIII, L., 1968, pp. 127-42.

- 'Srpsko pletenije sloves do 14 stoljeća', RZSF, V., Zagreb, 1963, pp. 117-29.

Nekrasov I., Paxonij Serb-pisatel' XV reka, Odessa, 1871.

Nikol'akaja A. B., 'Slovo mitropolita Ilariona $v$ pozdnejšej literaturnoj tradicii', Slavia, VII, Prague, 1928, pp. 549-563, 853-70.

Obolensky D., The Byzantine Comeonvealth, London, 1971.

Orlov A. S., Drevnjaja rugskaja literatura XI-XVI vv., M-L., 1937.

Orlov A. S., Adrianova Peretc V. P., Gudzij N. K., (eds.), Istorija

russkoj literatury, I, II pt. i, M-L., 1941-5. 
Petkanora-Totera D., 'Nori Čerti ne poxvalnoto elovo prez XIV-XV V.', Tămoreka kni ̌oma Čkola, 1371-91, (Meždunaroden aimpoziun, Veliko Tărnovo, 11-14 oktourri, 1971), ede. P. Ruser, G. Dančer, E. Sarafova, Sofia, 1974, pp. 89-112.

Petuxov E. V., Pusakeja literatura: drevnij period, Jur'ev, 1912.

Popruženko M. G., 'Iz iatorii religiomogo dviženija $v$ Bolgarii $v$ XIV v.', Slavia, VII, Prague, 1928, pp. 536-48.

Priselkov M. D., 'Pussko-vizantijskije otnołenija IX-XII rv.', Vestnik dremej istorii, 3, M., 1939, pp. 98-109.

Proxorov G. M., 'Etničeskaje integracija $v$ Vostočnoj Evrope $v$ XIV reke', Geograf ičcekoje obăčestvo SSSR. Otdelenije etnografi i, Doklady, II, L., 1966, pp. 81-110.

- 'Isixazm i obščestrennaja cysi' v vostočnoj Evrope', TODL, XXIII, L., 1968, pp. 86-108.

- 'Kelejnaja isixastokaja literatura (Ioann Leatričnik, Arva Dorofej, Inaak Sirin, Simeon Novyj Bogoslov, Grigorij Sinait) $v$ biblioteke Troice-Sergievoj lavry c XIv po XVII v.', TODL, XXVIII, L., 1974, pp. 317-25.

Radčenko K. F., 'Religiomoje i literaturnoje dviŽenije v Bolgarii', Universitetakije izvertije, Kiev, 1898, 5, pp. 1-51; 6, pp. 51-168; 7, pp. 169-242;8, pp. 243-344. 
Sal'aina M. A., 'Slovo O Yitii i o prestavlenii velikono knjazia Daterisa Ivanovič, carta rug'skeo', TODL, XXV, M-L., 1970, pp. 81-104.

Sazonova L. I., 'Princip ritaičeskoj organizacii $v$ proizredenijax toržestrennogo krasnorečija starłej pory (Slovo o zakone i blagodati Ilariona, Poxvala ov. Siceonu i av. Savre Domentiana)', TODL, XXVIII, L., 1974, pp. 30-46.

Schmass A., 'Die literarhistorische Problematik ron Domentijans Sava-Vita', Slawistische Studien an $V$. internationalen Slavistenkongresa in Soria, 1963, Gottingen, 1963, pp. 121-42.

Sedel'nikov A. D., 'Iz oblasti literaturnogo obščenija $v$ načale XV veka (Kirill Tverskoj i Epifanij Moskovskoj)', Izvestija otdelenija russkogo jezke i lovesnosti, XXXI, L., 1926, pp. 159-76.

Siefkes F., zur Fore des Žtije Feodosije. Vergleichende Studien zur byzant inischen und altrussischen Literatur; (Frankfurter Abhandlungen zur Slavistik, XII), Bad Honburg-Berlin-Z4rich, 1970.

Snegarev I., Duzovno-talturni vrăzki beždu Bălgarija i Pusija prez srednite rekove (X-XV vv.), Sofia, 1950.

- 'K istorii kul'turnyx svjazej bełdu Bolgarijej i Rossijej v konce XIV-naX̌ale XV V.', Meždunarodnyje avjazi Rosei i doXVII v. Sbornik statej., (eds. A. A. Zinin, V. T. Pašuto), M., 1961, pp. $257-77$. 
Sobolerskij A. I., Jutho-glavjanskoje vlijenije ma rusakaju pia'mannoat' VXIV-XY vaknx', St. P., 1894, also in Porovodnaja literatura Mogkorskoj Pusi XIV-XVII rekor, (ORJS), LXXIV, St. P., 1903. pp. 1-37.

Solor'or A. V., 'Epifanij Promudryj kak artor Slova o Gitil i prestavlenii relikago knjazia Daitrija Iranoriča, carja rus'akago', TODL, XVII, M-L, 1961, Pp. 85-106.

Spasskij F. G., Puaskoje liturg LCeskoje trorCestro po sorresennye ninejas, Paris, 1951.

Speranakij M. N., Intorife dremel ruaskoj literatury, M., 1921.

$$
\begin{aligned}
& \text { - 'Iz mabljudenij nad elołnyei sovani } v \text { stils rusakoj literaturnoj } \\
& \text { Ykoly XV-XVI V.', Iz iatorii rusako-slavjangkix literaturnyx } \\
& \text { evjazej, M., 1960, pp. 160-97. } \\
& \text { - 'Pusskije panjatniki pie'mennosti } \vee \text { jugoslavjanskix literaturax } \\
& \text { XIV-XV Vv.', Iz istorii russko-slavjanakix literaturnyx evjazoj. } \\
& \text { M. , 1960, pp. 55-103. }
\end{aligned}
$$

Sremerakij I. I., Materialy dlja slovarja drevne-rusakogo jazke, I-III,

$$
\text { St. P., 1893-1912. }
$$

Stäojerić St. and Glunac D., Sr. Piseo u nǎ̌ie starie sponeniciea, Belgrade, 1932.

Syrku P. A., K ietorii ispravlenija knis V Bolgarii V XIV veke, pt. i, Vrasia i žizn' patriarxa Evtinija Ternovskogo; pt. ii, 
LiturgiČelkije trudy patriarxa Erfinija Ternorskono, St. P., $1888-90$.

- Očerki iz istorii literaturnyx enołenij Bolgar i Serbov v

XIV-XVII vekax, St. P., 1901.

Talev I., Sope problens of the Second South Slavic influence in Russia,

(Slavistische Beitrüge, LXVII,), Munich, 1973.

Tixoøirov M. N., 'Istoričeskije svjazi russkogo naroda juð̌nymi slavjanami', Slavjanskij sbornik, M., 1947, pp. $166-80$.

- 'Puti iz Kossii v Vizantiju v XIV-XV vv.', Vizantijakije dXerki, M. , 1961.

- Srednevakovaja Rossija na meždunarodnyx putjax, M., 1966.

- 'Vizantija i Moskovskaja Kass'', IstoriČeskij Z̆urnal, 1-2, M., 1945, pp. 9-13.

Trifunović D., 'Pripovedanje i simboli srednevekovne nałe umetničke proze', Delo, v, 8-10, Belgrade, 1958, pp. 1143-58, 1266-92.

Turdeanu E. La Littérature bulgare du XIV siècle, Paris, 1947.

Tvorogov O. B., 'Zadnči izučenija ustojčivyx literaturnyx formul drevnej Pusi', TODL, XX, M-L., 1964, pp. 29-40.

Vaillant A., 'Notes sur la Vie d'Etienne de Pere'', RES, XLV, 1966, pp. 33-7.

Vasil'ev V. P., Istorija kanonizacii rusakix svjatyx, M., 1897. 
Vranska C., Stilni porvati na patriare Dutinij, Sofia, 1942.

Vzdornor G. I., 'Rol' slavjanskix mostyrakix msterakix pis'm

Konstantinopolja i Afona $v$ razvitil knigopisanija i rudoŽestrennogo oformlenija russkix rukopisej na rubeže XIV-XV VV., TOOL., XXIII, L., 1968, pp. 171-98.

Weingart M., Byzantinakě kroniký v 1iterature církevněslovangké, Brat islava, 1922.

Wigzell F., 'Citaty iz knio avjaščennogo pisanija $v$ sočinenijar Epifanija Premudrogo', TODL, XXVI, L., 1971, pp. $232-43$.

- 'Convention and originality in the Life of Stefan of Pera':

a stylistic analysio', Slavonic and East Duropean Rovier, XlIX, 116, London, 1971, pp. 339-55.

Lypf L., Das Heiligen-Leben in 10. Jahrhundert, Leipzig-Berlin, 1908.

Zubov B. P., 'Epifanij Premudryj i Paxomij Serb.K voprosu o redakcijax Zitija Sergija Radonezskogo , TODL, IX, M-L., 1953, pp. 145-58. 


\section{$S L A V I S T I S C H E$ I $C$ I I T R ̈̈GE}

Verzeichnis der 1975 erschienenen Bände

83. Baumann, W.: Die Sage von Heinrich dem Löwen bei den Slaven. 1975. $185 \mathrm{~S}$.

84. Everts-Grigat, S.: V. V. Majakovskij: Pro éto. Ubersetzung und Interpretation. 1975. $262 \mathrm{~S}$.

85. Mirsky, S.: Der Orient im Werk Velimir Chlebnikovs. 1975. VIII, $112 \mathrm{~S}$.

86. Ditterich, M.: Untersuchungen zum altrussischen Akzent anhand von Kirchengesangshandschriften. 1975. $147 \mathrm{~S}$.

87. Cummins, G. M.: The Language of the Old Czech Legenda o svaté Katefine. 1975. VIII, $371 \mathrm{~S}$.

88. Földeak, H.: Neuere Tendenzen der sowjetischen Science Fiction. 1975. VI, $208 \mathrm{~s}$.

89. Drews, P.: Devétsil und Poetismus. Künstlerische Theorie und Praxis der tschechischen literarischen Avantgarde am Beispiel Vitézslav Nezvals, Jaroslav Seiferts und Jifí Wolkers. 1975. $330 \mathrm{~s}$.

90. Schönle, P. W.: Zur Wortbildung im modernen Russisch. 1975. VIII, $195 \mathrm{~S}$.

91. Okuka, M.: Sava Mrkalj als Reformator der serbischen Kyrilliza. Mit einem Nachdruck des Salo debeloga jera libo Azbukoprotres. 1975. $123 \mathrm{~S}$.

92. Neuhäuser, R.: The Romantic Age in Russian Literature: Poetic and Esthetic Norms. An Anthology of Original Texts $(1800-$ 1850). 1975. VIII, $300 \mathrm{~S}$.

93. Döring, J. R. (Hrg.): Literaturwissenschaftliches Seminar: Zur Analyse dreier Erzählungen von Vl. I. Dal'. Mit einem methodologischen Geleitwort von Johannes Holthusen. 1975. 203 S.

94. Alexander, R.: Torlak Accentuation. 1975. XVI, 806 S.

1976

95. Schenkowitz, G.: Der Inhalt sowjetrussischer Vorlesestoffe für Vorschulkinder. Eine quantifizierende Corpusanalyse unter Benutzung eines Computers. 1976. $767 \mathrm{~S}$.

96. Kitch, F. C. M.: The Literary Style of Epifanij Premudryj. Pletenije sloves. 1976. $298 \mathrm{~S}$.

\section{IN VORBEREITUNG}

97. Eschenburg,B.: Linguistische Analyse der ortsnamen der ehemaligen Komitate Bács und Bodrog von der ungarischen Landnahme (896) bis zur Schlacht von Mohács. 1976. $156 \mathrm{~S} ., 3 \mathrm{kt}$.

98. Lohse, H.: Die Ikone des hl. Theodor Stratilat zu Kalbensteinberg. Eine philologisch-historische Untersuchung.1976. XX,242 S.

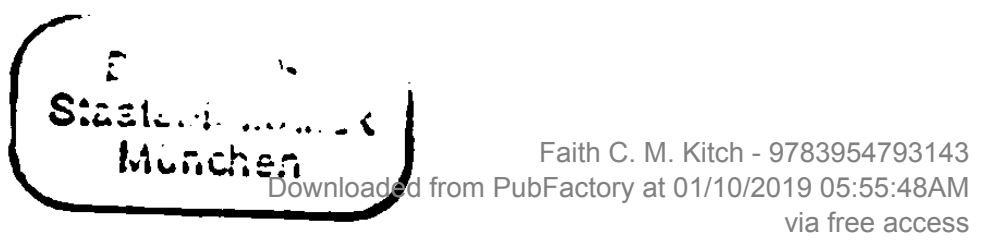

